\title{
2. SITE 502: COLOMBIA BASIN, WESTERN CARIBBEAN SEA ${ }^{1}$
}

\author{
Shipboard Scientific Party²
}

\section{HOLE 502}

Date occupied: 16 August 1979

Date departed: 19 August 1979

Time on hole: $72 \mathrm{hr}$.

Position: $11^{\circ} 29.42^{\prime} \mathrm{N}, 79^{\circ} 22.78^{\prime} \mathrm{W}$

Water depth (sea level; corrected m; echo-sounding): 3051.5

Water depth (rig floor; corrected m; echo-sounding): 3061.5

Penetration (m): 214.10

Number of cores: 50

Total length of cored section (m): 214.10

Total cores recovered $(\mathrm{m}): 154.35$

Core recovery $(\%): 72.1$

Oldest sediment cored:

Depth sub-bottom: 210.26

Nature: Calcareous clay

Age: Late Miocene

Measured velocity $(\mathrm{km} / \mathrm{s}): 1.5841(209.92 \mathrm{~m})$

Shear strength $\left(\mathrm{g} / \mathrm{cm}^{2}\right): 3069.6(198.6 \mathrm{~m})$

\section{HOLE 502A}

Date occupied: 19 August 1979

Date departed: 23 August 1979

Time on hole: $88 \mathrm{hr}$.

Position: $11^{\circ} 29.46^{\prime} \mathrm{N}, 79^{\circ} 22.74^{\prime} \mathrm{W}$

Water depth (sea level; corrected $\mathbf{m}$; echo-sounding): 3051.5

Water depth (rig floor; corrected m; echo-sounding): 3061.5

Penetration (m): 215.00

Number of cores: 68

Total length of cored section (m): 215.00

\footnotetext{
${ }^{1}$ Prell, W. L., Gardner, J. V., et al., Init. Repts. DSDP, 68: Washington (U.S. Govt. Printing Office).

2 Warren L. Prell (Co-Chief Scientist), Department of Geological Sciences, Brown University, Providence, Rhode Island; James V. Gardner (Co-Chief Scientist), Pacific-Arctic Branch of Marine Geology, U.S. Geological Survey, Menlo Park, California; Charles Adelseck, Deep Sea Drilling Project, Scripps Institution of Oceanography, La Jolla, California (present address: McClelland Engineers, Ventura, California); Gretchen Blechschmidt, Lamont-Doherty Geological Observatory, Columbia University, Palisades, New York (present address: Exxon Production and Research Corp., Houston, Texas); Andrew Fleet, Department of Earth Sciences, Open University, BuckInghamshire, United Kingdom (present address: Geochemistry Branch Explor, and Prod. Division British Petroleum Research Center, Sudbury-on-Thames, Middlesex TW16 7LN United Kingdom); Lloyd Keigwin, Jr., Graduate Sudbury-on-Thames, Middlesex TW16 7LN United Kingdom); Lloyd Keigwin, Jr., Graduate
School of Oceanography, University of Rhode Island, Kingston, Rhode Island (present address: Woods Hole Oceanographic Institution, Woods Hole, Massachusetts); Dennis Kent, Lamont-Doherty Geological Observatory, Columbia University, Palisades, New York; Michael T. Ledbetter, Department of Geology, University of Georgia, Athens, Georgia; Ulrich Mann, Institut für Sedimentforschung, Universität Heidelberg, Heidelberg, Federal Republic of Germany; Larry A. Mayer, Graduate School of Oceanography, University of Rhode Island, Kingston, Rhode Island; William R. Riedel, Geological Research Division, Scripps Institution of Oceanography, La Jolla, California; Constance Sancetta, Lamont-Doherty GeoDoherty Geological Observatory, Columbia University, Palisades, New York; Herman B. Zimmerman, Department of Geology, Union College, Schenectady, New York.
}

Total cores recovered $(\mathrm{m}): 176.50$

Core recovery $(\%): 82.2$

Oldest sediment cored:

Depth sub-bottom: 215.00

Nature: Calcareous clay

Age: Late Miocene

Measured velocity $(\mathrm{km} / \mathrm{s}): 1.5529(214.43 \mathrm{~m})$

Shear strength $\left(\mathrm{g} / \mathrm{cm}^{2}\right): 2490.38(197.21 \mathrm{~m})$

\section{HOLE 502B}

Date occupied: 23 August 1979

Date departed: 25 August 1979

Time on hole: $36 \mathrm{hr}$.

Position: $11^{\circ} 29.51^{\prime} \mathrm{N}, 79^{\circ} 22.69^{\prime} \mathrm{W}$

Water depth (sea level; corrected m; echo-sounding): 3051.5

Water depth (rig floor; corrected m; echo-sounding): 3061.5

Penetration (m): 98.55

Number of cores: 23

Total length of cored section (m): 98.55

Total core recovered $(\mathrm{m}): 86.31$

Core recovery (\%): 87.6

Oldest sediment cored:

Depth sub-bottom: 97.64

Nature: Foraminifer-bearing nannofossil marl

Age: Mid-Pliocene

Measured velocity $(\mathrm{km} / \mathrm{s}): 1.5473(98.6 \mathrm{~m})$

Shear strength $\left(\mathrm{g} / \mathrm{cm}^{2}\right): 802.26(98.5 \mathrm{~m})$

\section{HOLE 502C}

Date occupied: 25 August 1979

Date departed: 27 August 1979

Time on hole: $45 \mathrm{hr}$.

Position: $11^{\circ} 29.48^{\prime} \mathrm{N}, 79^{\circ} 22.70^{\prime} \mathrm{W}$

Water depth (sea level; corrected m; echo-sounding): 3051.5

Water depth (rig floor; corrected m; echo-sounding): 3061.5

Penetration (m): 227.81

Number of cores: 37

Total length of cored section $(\mathrm{m}): 130.70$

Total core recovered $(\mathrm{m}): 112.70$

Core recovery (\%): 86.2

Oldest sediment cored:

Depth sub-bottom: 227.81

Nature: Calcareous clay

Age: Late Miocene

Measured velocity $(\mathrm{km} / \mathrm{s}): 1.5506(226.45 \mathrm{~m})$

Shear strength $\left(\mathrm{g} / \mathrm{cm}^{2}\right): 2397.72(214.96 \mathrm{~m})$ 


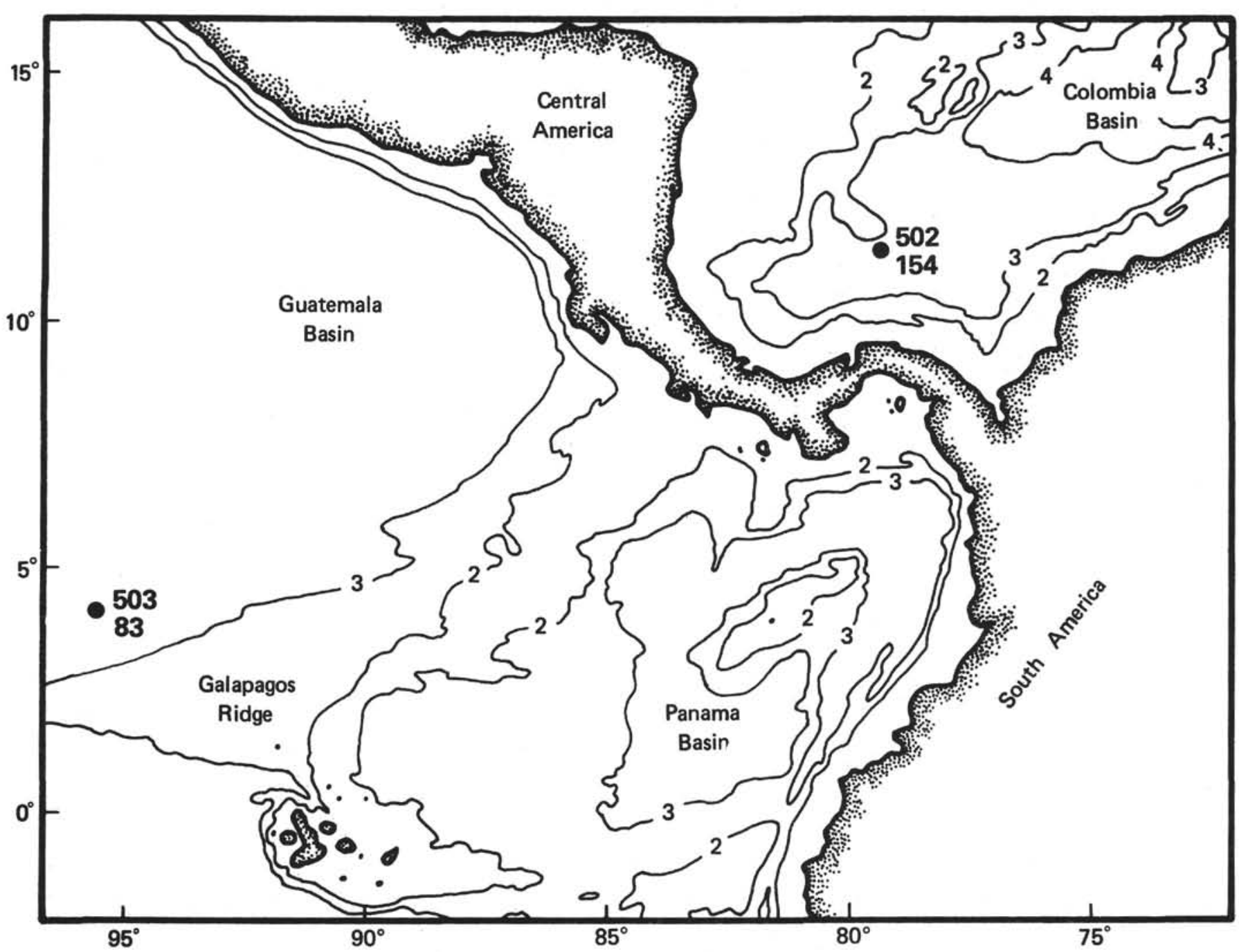

Figure 1. Location of Sites 502 (Leg 68) and 154 (Leg 15) in the Colombia Basin, Caribbean Sea.

\section{COLOMBIA BASIN, WESTERN CARIBBEAN SEA, SITE 502 BACKGROUND AND OBJECTIVES}

Site 502 is located in the Caribbean Sea, Colombia Basin (Fig. 1), on a small fault block that rises above the surrounding seafloor (Fig. 2). The location of Site 502 was based on the results from Site 154, which was drilled approximately $100 \mathrm{~km}$ to the southwest. Site 154 recovered a 153-meter section of nannofossil marl and calcareous clay of Pleistocene and Pliocene age overlying a volcanic-terrigenous sequence. The volcanic-terrigenous sequence forms a prominent reflector that was the prime target for the drilling of Site 154. Sediment accumulation rates in the pelagic-hemipelagic section at Site 154 are 4 to $5 \mathrm{~cm} / \mathrm{ky}$ (Edgar, Saunders, et al., 1973) and are similar to rates that occur in the upper Pleistocene sections from the Colombia Basin (Prell, 1978).

We chose the location of Site 502 to avoid the terrigenous sands encountered at Site 154 and to recover a thick sequence of the hemipelagic to pelagic facies. We expected accumulation rates at Site 502 to range from 3 to $4 \mathrm{~cm} / \mathrm{ky}$, somewhat slower than rates at the deeper Site 154 and adjacent piston cores.
Our specific objective at Site 502 was to recover an undisturbed, complete section that could be used as a Neogene and Quaternary reference section. A complete record such as this would allow intercorrelations between (1) paleomagnetic stratigraphy, (2) calcareous biostratigraphy, (3) cyclic accumulation of sediment, (4) paleoceanographic changes, (5) oxygen and carbon isotope stratigraphies, (6) the chronology of Central American volcanism, (7) the timing and effects of the emergence of the Isthmus of Panama, and (8) the timing and effects of the initiation of Northern Hemisphere glaciation.

In addition to the scientific objectives, this cruise was designed to accomplish several engineering objectives. We hoped to determine (1) the maximum penetration of the HPC, (2) the physical properties of the sediment that stop penetration of the HPC, and (3) how much sediment is lost and/or disturbed between HPC cores because of coring operations. Site 502 should therefore provide important data on the capabilities of the HPC in calcareous hemipelagic sediment.

To meet these objectives, we attempted to recover at least three closely spaced, continuous sections by staggering the depth interval of the cores. Staggered coring 


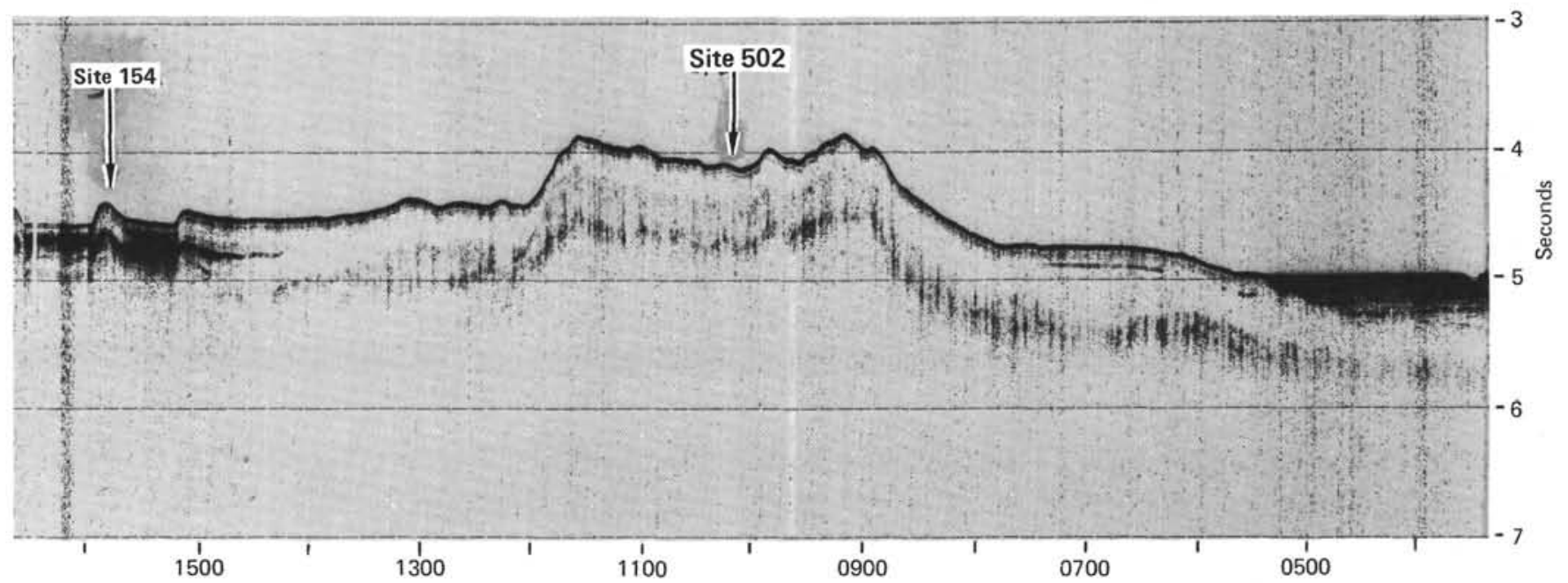

Figure 2. A seismic profile (GC-15) of the western Colombia Basin showing the relative position of Sites 154 and 502 . Note that the strong subbottom reflector at Site 154 is absent at Site 502.

places the core break in one hole midway in the recovered section of an adjacent hole. These offset cores enabled us to construct a composite section of the site and avoid potential hiatuses due to coring.

\section{OPERATIONS}

We departed Curaçao on 13 August at $1056 \mathrm{hr}$. for sea trials and completed them by $1430 \mathrm{hr}$. We were underway for Site 502 at $1600 \mathrm{hr}$. and tested the positioning system (1907-2010 hr.) en route. The area of Site 502 was approached on 15 August at $2300 \mathrm{hr}$. on a course of $260^{\circ}$. Our course was changed to $198^{\circ}$ so that we could obtain a seismic profile across the prospective site on a course of $300^{\circ}$ that bisects the Vema 3208 and Glomar Challenger (GC-15) lines (Fig. 3). We continued to profile on this course for approximately two hours to

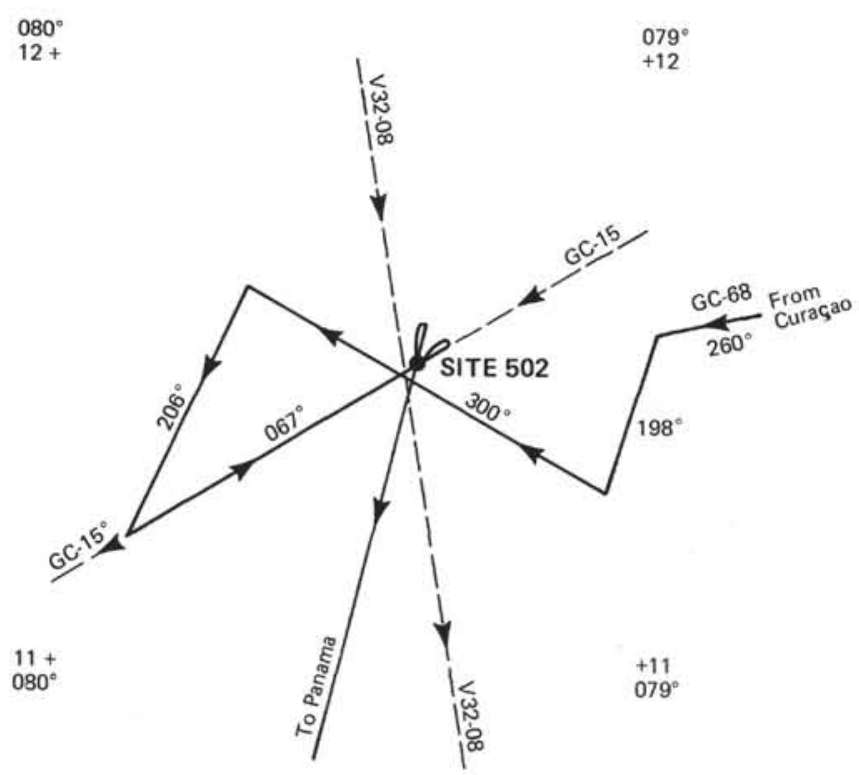

Figure 3. Tracklines of approach and departure of GC-68 from Site 502. The GC-68 track is a solid line and the tracks for V32-08 and GC-15 are dashed lines. ensure that we chose an optimum location. Our course was then changed to $206^{\circ}$ to intersect the GC-15 line. Once on the GC-15 line, we followed it on a course of $067^{\circ}$ and dropped a presoaked beacon (ORE \#504) at $1425 \mathrm{hr}$. local time. Figure 4 shows our crossing of Site 502 . We were positioned over the beacon by $1508 \mathrm{hr}$.

Continuous coring began with the HPC at $1753 \mathrm{hr}$. Fifty-three HPC attempts were made at Hole 502 that penetrated to a depth of 214.10 meters with recovery of 154.35 meters of sediment (Table 1). We attempted to recore several intervals where we initially got no recovery, but we were unsuccessful. Although total recovery was $72.1 \%$, it was $82.4 \%$ in the upper 100 meters, where the HPC fully extended. Full extension of the HPC (indicated by a decrease in water pressure) stopped at Core 30 (122.8-125.8 $\mathrm{m}$ sub-bottom), but we continued to core at 4.4-meter intervals. Hole 502 was abandoned after Core 50 because recovery was less than 1 meter.

The ship was moved 100 meters northeast of Hole 502, and coring of Hole 502A was underway at $2045 \mathrm{hrs}$ on 19 August. Hole 502A was continuously cored to a maximum depth of 215.0 meters sub-bottom. The HPC ceased fully extending at about 116 meters sub-bottom (Core 28). At this point, instead of washing down 4.4 meters as we did at Hole 502, we measured the length of recovered core, then washed to the nearest 0.5 meters less than the recovery. As an example, if Core 17 recovered 3.25 meters of sediment, we washed down 3.0 meters before extending the HPC for Core 18. Hole 502A was abandoned at $1315 \mathrm{hr}$. on 23 August at 215.0 meters sub-bottom, when recovery was less than 2 meters per attempt. Total recovery was $82.2 \%$ (Table 1 ).

We moved the ship about 100 meters northeast of Hole $502 \mathrm{~A}$ and spudded in Hole 502B. Hole 502B was started at $1525 \mathrm{hr}$. on 23 August and penetrated to a depth of 98.55 meters before the HPC became stuck in the inner barrel. Set screws that hold the upper assembly oriented with the lower assembly had sheared, and one had jammed between the inner core barrel and the drill string. All attempts to free the HPC were unsuccessful. We 


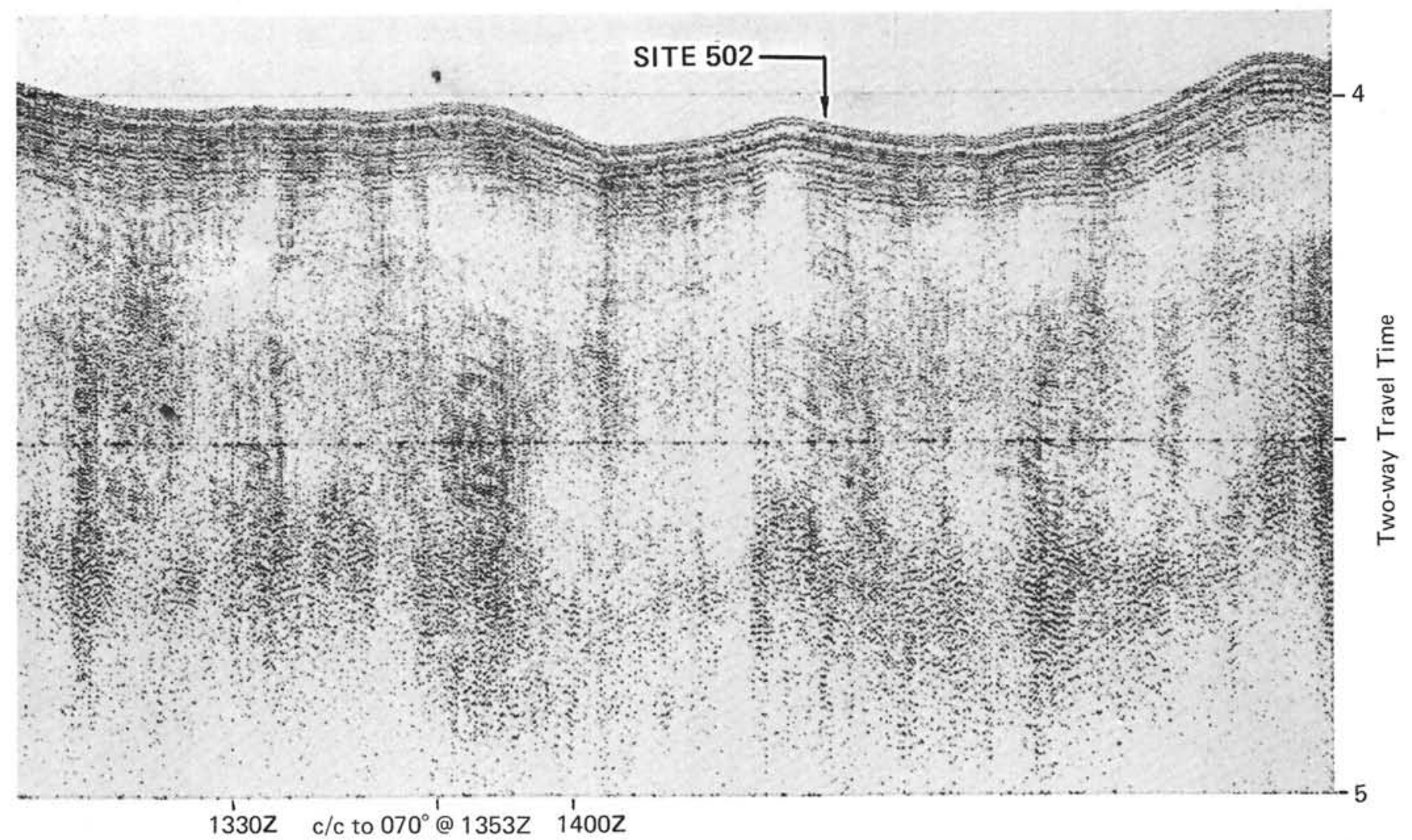

Figure 4. The Glomar Challenger, Leg 68 airgun seismic profile (filtered at $80 / 640 \mathrm{~Hz}$ ) across Site 502 .

abandoned Hole 502B at 1900 on 24 August after 86.31 meters of sediment was recovered for a recovery of $87.6 \%$. (Table 1).

Hole $502 \mathrm{C}$ was cored at the same location as Hole 502B. The seafloor was reached at $1050 \mathrm{hr}$. on $25 \mathrm{Au}-$ gust, and washed down to 32 meters sub-bottom. We commenced continuous coring from 32.0 meters to 144.2 meters, using the same strategy as on Holes 502A and 502B. The 66-meter interval from 144.2 to 210.2 meters was washed, and we again continuously cored from 210.2 meters to 227.8 meters. Hole $502 \mathrm{C}$ was abandoned at $0920 \mathrm{hr}$. on 27 August because of time constraints on our arrival in Panama. However, our recovery dropped off sharply after 225.7 meters sub-bottom, and the last core only recovered $10 \mathrm{~cm}$ of sediment. Table 1 is a summary of our coring operations at Site 502 .

The drill string was recovered by $1600 \mathrm{hr}$. on 27 August. We were underway at $2142 \mathrm{hr}$., streaming the geophysical gear on a course of $014^{\circ}$. Once the geophysical gear was in operation, we changed course to $191^{\circ}$ and profiled across Site 502, then continued profiling on a track to Cristobal, Panama. The geophysical gear were secured at $0446 \mathrm{hr}$. on 28 August owing to ship traffic.

\section{LITHOSTRATIGRAPHY}

We divided the section into four lithologic units (Table 2). The major facies is hemipelagic with foraminifer and nannofossil marl in the upper portion, grading into marl and clay in the lower sections. The division into four units is based on carbonate content, color, and mineral and biogenic constituents.

\section{Major Lithofacies}

\section{Unit A (0-7 m sub-bottom)}

Unit A consists of foraminifer-bearing nannofossil marl with subsidiary foraminifer-nannofossil marl. The marl is yellowish brown grading into a light brownish gray with depth. Sediment from Holes 502 and 502B exhibits a distinct cyclical color pattern at the base of the unit. Sediment from Hole 502A shows no color cycles; instead, a long transition section of light brownish gray sediment leads directly into the underlying unit. The unit is structureless, with only occasional faint laminations and minor mottling. A visible coarse component of foraminifers is scattered throughout.

The major constituents (Table 3, Appendix, this chapter) are abundant nannofossils and undifferentiated clay minerals and common to abundant foraminifers. Micronodules are rare to common, whereas siliceous microfossils, volcanic glass shards, quartz, heavy mineral grains, and pyrite are present in trace amounts. The coarse fraction contains subhedral to euhedral grains of quartz, potash and plagioclase feldspar, green and red hornblende, and, rarely, brown mica. X-ray diffraction data show the presence of minor amounts of the zeolites clinoptilolite and phillipsite. The clay mineral component consists of abundant montmorillonite, common to 
Table 1. Coring summary for Site $\mathbf{5 0 2 .}$

\begin{tabular}{|c|c|c|c|c|c|c|c|}
\hline $\begin{array}{l}\text { Core } \\
\text { No. }\end{array}$ & $\begin{array}{c}\text { Date } \\
\text { (August } \\
\text { 1979) }\end{array}$ & $\begin{array}{l}\text { Time } \\
\text { (hr.) }\end{array}$ & $\begin{array}{l}\text { Depth from } \\
\text { Drill Floor } \\
\text { (m) } \\
\text { Top Bottom }\end{array}$ & $\begin{array}{l}\text { Depth below } \\
\text { Seafloor } \\
\text { (m) } \\
\text { Top Bottom }\end{array}$ & $\begin{array}{l}\text { Length } \\
\text { Cored } \\
(\mathrm{m})\end{array}$ & $\begin{array}{c}\begin{array}{c}\text { Length } \\
\text { Recovered } \\
\text { (m) }\end{array}\end{array}$ & $\begin{array}{c}\text { Recovery } \\
(\%)\end{array}$ \\
\hline Hole & & & & & & & \\
\hline 1 & 16 & 1829 & $3047.5-3051.9$ & $0.0-0.4$ & 0.4 & 0.20 & 50.0 \\
\hline 2 & 16 & 2010 & $3051.9-3056.3$ & $0.4-4.8$ & 4.4 & 4.45 & 101.1 \\
\hline 3 & 16 & 2122 & $3056.3-3060.7$ & $4.8-9.2$ & 4.4 & 4.05 & 92.0 \\
\hline 4 & 16 & 2248 & $3060.7-3065.1$ & $9.2-13.6$ & 4.4 & 4.42 & 96.9 \\
\hline 5 & 16 & 2358 & $3065.1-3069.5$ & $13.6-18.0$ & 4.4 & 4.13 & 97.9 \\
\hline 6 & 17 & 0115 & $3069.5-3073.9$ & $18.0-22.4$ & 4.4 & 3.92 & 89.1 \\
\hline 7 & 17 & 0236 & $3073.9-3078.3$ & $22.4-26.8$ & 4.4 & 4.50 & 102.3 \\
\hline 8 & 17 & 0358 & 3078.3-3082.7 & $26.8-31.2$ & 4.4 & 4.14 & 94.1 \\
\hline & 17 & 0502 & $3082.7-3087.1$ & $31.2-35.6$ & 4.4 & 4.20 & 95.4 \\
\hline $\begin{array}{l}10 \\
11\end{array}$ & ${ }_{17}^{17}$ & $\begin{array}{l}0614 \\
0713\end{array}$ & $3087.1-3091.5$ & $\begin{array}{l}35.6-40.0 \\
40.0-44.4\end{array}$ & $\begin{array}{l}4.4 \\
4.4\end{array}$ & 4.22 & $\begin{array}{l}95.9 \\
320\end{array}$ \\
\hline $\begin{array}{l}11 \\
12\end{array}$ & $\begin{array}{l}17 \\
17\end{array}$ & $\begin{array}{l}0713 \\
0811\end{array}$ & $\begin{array}{l}3091.5-30095.9 \\
3095.9-3100.3\end{array}$ & $\begin{array}{l}\begin{array}{r}40.00-44.4 \\
44.4-48.8\end{array} \\
\end{array}$ & $\begin{array}{l}4.4 \\
4.4\end{array}$ & 1.41 & 32.0 \\
\hline 13 & 17 & 0910 & $\begin{array}{l}3005.9-3100.3 \\
3100.3-3104.7\end{array}$ & $\begin{array}{l}44.4-48.8 \\
48.8-53.2\end{array}$ & $\begin{array}{l}4.4 \\
4.4\end{array}$ & $\overline{4.20}$ & $\overline{95.4}$ \\
\hline 14 & 17 & 1127 & $3104.7-3109.1$ & $53.2-57.6$ & 4.4 & 2.63 & 59.8 \\
\hline 15 & 17 & 1238 & $3109.1-3113.5$ & $57.6-62.0$ & 4.4 & 3.83 & 87.0 \\
\hline 16 & 17 & 1341 & $3113.5-3117.9$ & $62.0-66.4$ & 4.4 & 2.59 & 58.9 \\
\hline 17 & 17 & 1502 & $3117.9-3122.3$ & $66.4-70.8$ & 4.4 & 3.10 & 70.4 \\
\hline 18 & 17 & 1605 & $3122.3-3126.7$ & $70.8-75.2$ & 4.4 & 2.39 & 54.3 \\
\hline 19 & 17 & 1810 & $3126.7-3131.1$ & $75.2-79.6$ & 4.4 & 3.67 & 83.4 \\
\hline 20 & 17 & 1920 & $3131.1-3135.5$ & $79.6-84.0$ & 4.4 & 3.93 & 89.3 \\
\hline $\begin{array}{l}21 \\
22\end{array}$ & ${ }_{17}^{17}$ & $\begin{array}{l}2050 \\
2153\end{array}$ & $\begin{array}{l}3135.5-3139.9 \\
31390-3144 .\end{array}$ & $\begin{array}{l}84.0-88.4 \\
88.4-92.8\end{array}$ & $\begin{array}{l}4.4 \\
4.4\end{array}$ & $\begin{array}{l}3.44 \\
3.92\end{array}$ & 78.2 \\
\hline 23 & $\begin{array}{l}177 \\
17\end{array}$ & $\begin{array}{l}2253 \\
2258\end{array}$ & $\begin{array}{l}31193.9-391144.3 \\
3144.3-3148.7\end{array}$ & $\begin{array}{l}88.4-99.8 \\
92.8-97.2\end{array}$ & $\begin{array}{l}4.4 \\
4.4\end{array}$ & $\begin{array}{l}3.92 \\
4.56\end{array}$ & $\begin{array}{r}89.1 \\
103.6\end{array}$ \\
\hline 24 & 18 & 0014 & $3148.7-3153.1$ & $97.2-101.6$ & 4.4 & 4.35 & 98.9 \\
\hline 25 & 18 & 0115 & $3153.1-3157.5$ & $101.6-106.0$ & 4.4 & 4.34 & 98.6 \\
\hline 26 & 18 & 0228 & $3157.5-3161.9$ & $106.0-110.4$ & 4.4 & 4.05 & 92.0 \\
\hline 27 & 18 & 0548 & $3161.9-3166.3$ & $110.4-114.8$ & 4.4 & 1.82 & 41.4 \\
\hline 28 & 18 & 0818 & $3166.3-3168.8$ & $114.8-117.3$ & 2.5 & & 96.0 \\
\hline 29 & 18 & 1000 & $3168.8-3173.2$ & $117.3-121.7$ & 4.4 & & 95.2 \\
\hline 30 & 18 & 1117 & & $121.7-126.1$ & 4.4 & 4.06 & 92.3 \\
\hline 31 & 18 & 1300 & $3177.6-3182.0$ & $126.1-130.5$ & 4.4 & 3.24 & 73.6 \\
\hline${ }_{33}^{32}$ & 18 & 1439 & $3182.0-3186.4$ & $130.5-134.9$ & 4.4 & 3.46 & 78.6 \\
\hline $\begin{array}{l}33 \\
34\end{array}$ & $\begin{array}{l}18 \\
18\end{array}$ & $\begin{array}{l}1617 \\
1727\end{array}$ & $\begin{array}{l}3186.4-3190.8 \\
3190.8-3195.2\end{array}$ & $\begin{array}{l}134.9-139.3 \\
139-143.7\end{array}$ & $\begin{array}{l}4.4 \\
4.4\end{array}$ & $\begin{array}{l}2.04 \\
4.14\end{array}$ & $\begin{array}{l}46.4 \\
94.1\end{array}$ \\
\hline 35 & $\begin{array}{l}18 \\
18\end{array}$ & $\begin{array}{l}1727 \\
1841\end{array}$ & $\begin{array}{l}3195.8-2-3195.2 \\
3195.2-6\end{array}$ & $\begin{array}{l}139,3-1343.7 \\
143.7-148.1\end{array}$ & $\begin{array}{l}4.4 \\
4.4\end{array}$ & $\begin{array}{l}4.14 \\
2.88\end{array}$ & $\begin{array}{l}94.1 \\
65.5\end{array}$ \\
\hline 36 & 18 & 2003 & $3199.6-3204.0$ & $148.1-152.5$ & 4.4 & 3.43 & 78.0 \\
\hline 37 & 18 & 2314 & $3204.0-3208.4$ & $152.5-156.9$ & 4.4 & 3.25 & 73.9 \\
\hline 38 & 19 & 0037 & $3208.4-3212.8$ & $156.9-161.3$ & 4.4 & 2.78 & 63.2 \\
\hline 39 & 19 & 0216 & $3212.8-3217.2$ & $161.3-165.7$ & 4.4 & & 60.2 \\
\hline 40 & 19 & 0452 & & & 4.4 & & \\
\hline 41 & 19 & 0611 & & & 4.4 & & \\
\hline 42 & 19 & 0833 & $3226.0-3230.4$ & 174.5-178.9 & 4.4 & 3.72 & 84.5 \\
\hline${ }_{44}^{43}$ & 19 & 0937 & $3230.4-3234.8$ & $\begin{array}{l}178.9-183.3 \\
183.3187 .7\end{array}$ & 4.4 & 2.71 & 61.6 \\
\hline${ }_{45}^{44}$ & $\begin{array}{l}19 \\
19\end{array}$ & $\begin{array}{l}1115 \\
1219\end{array}$ & $\begin{array}{l}3234.8-32399.2 \\
3239.2-3243.6\end{array}$ & $\begin{array}{l}183.3-187.7 \\
187.7-192.1\end{array}$ & $\begin{array}{l}4.4 \\
4.4\end{array}$ & 2.11 & $\begin{array}{l}48.0 \\
48.4\end{array}$ \\
\hline 46 & 19 & 1335 & $\begin{array}{l}32239.2-322434.6 \\
3243.6-3248.0\end{array}$ & $192.1-196.5$ & 4.4 & 1.96 & $\begin{array}{l}48.4 \\
44.5\end{array}$ \\
\hline 47 & 19 & 1442 & $3248.0-3252.4$ & $196.5-200.9$ & 4.4 & 2.47 & 56.1 \\
\hline 48 & 19 & 1611 & $3252.4-3256.8$ & $200.9-205.3$ & 4.4 & 1.72 & 39.1 \\
\hline 49 & 19 & 1721 & $3256.8-3261.2$ & $205.3-209.7$ & 4.4 & 0.45 & 10.2 \\
\hline so & 19 & 1840 & $3261.2-3265.6$ & $209.7-214.1$ & 4.4 & 0.56 & 12.7 \\
\hline Total & & & & & 214.1 & 154.35 & 72.1 \\
\hline Hole S & & & & & & & \\
\hline 1 & 19 & 2155 & $3049.0-3053.4$ & $0.0-1.9$ & 1.9 & 1.62 & 85.3 \\
\hline 2 & 19 & 100 & 3053.4-305 & $9-6.3$ & 4.4 & 3.86 & 87.7 \\
\hline 3 & 20 & 05 & $3057.8-3062.2$ & $6.3-10.7$ & 4.4 & 4.20 & 95.4 \\
\hline 4 & 20 & 0200 & $3062.2-3066.6$ & $10.7-15.1$ & 4.4 & 4.03 & 91.6 \\
\hline 5 & 20 & 0503 & $3066.6-3071.0$ & $15.1-19.5$ & 4.4 & 4.34 & 98.6 \\
\hline 6 & 20 & 0906 & $3071.0-3075.4$ & $19.5-23.9$ & 4.4 & 4.21 & 95.7 \\
\hline & 20 & 1005 & $3075.4-3079.8$ & $23.9-28.3$ & 4.4 & 4.41 & 100.2 \\
\hline 8 & 20 & 112 & & 28.3 & 4.4 & 3.2 & 73.9 \\
\hline & 20 & & & & 4.4 & & \\
\hline 10 & 20 & & & & 4 & & \\
\hline 11 & 20 & 1652 & & & 4 & & 4.5 \\
\hline $\begin{array}{l}12 \\
13\end{array}$ & $\begin{array}{l}20 \\
20\end{array}$ & $\begin{array}{l}1755 \\
1900\end{array}$ & & $\begin{array}{l}45.9-50.3 \\
50.3-54.7\end{array}$ & $\begin{array}{l}4.4 \\
4.4\end{array}$ & $\begin{array}{l}3.96 \\
0.18\end{array}$ & 90.0 \\
\hline $\begin{array}{l}13 \\
14\end{array}$ & 20 & $\begin{array}{l}1900 \\
2015\end{array}$ & $\begin{array}{l}3101.8-3106.2 \\
3106.2-3110.6\end{array}$ & $\begin{array}{l}50.3-54.7 \\
547-59.1\end{array}$ & $\begin{array}{l}4.4 \\
4.4\end{array}$ & 0.18 & 4.1 \\
\hline is & 20 & 2130 & $3110.6-3115.0$ & $\begin{array}{l}54.7-59.1 \\
59.1-63.5\end{array}$ & $\begin{array}{l}4.4 \\
4.4\end{array}$ & $\begin{array}{l}0.00 \\
0.00\end{array}$ & $\begin{array}{l}0.0 \\
0.0\end{array}$ \\
\hline 16 & 20 & & & & 4.4 & 3.4 & 78.6 \\
\hline 17 & 21 & & 3.8 & 67.9 & 4.4 & 4. & 105.2 \\
\hline 18 & 21 & & & & 4.4 & 0. & 0.9 \\
\hline 19 & 21 & & & & 4. & 4. & .2 \\
\hline 20 & 21 & & & & 4 & & .4 \\
\hline 21 & 21 & 0509 & & & & & \\
\hline 22 & 21 & 0621 & & & & & \\
\hline 23 & 21 & 0734 & & & 4 & & 105.4 \\
\hline & ${ }_{21}^{21}$ & $\begin{array}{l}0848 \\
0957\end{array}$ & & $\begin{array}{l}98.7-10 \\
103.1-10\end{array}$ & $\begin{array}{l}4.4 \\
4.4\end{array}$ & $\begin{array}{l}4.58 \\
4.38\end{array}$ & 104.1 \\
\hline 26 & ${ }_{21}^{11}$ & $\begin{array}{l}0957 \\
1112\end{array}$ & $\begin{array}{l}\begin{array}{l}3154.6-315 \\
3159.0-316\end{array} \\
3150\end{array}$ & $\begin{array}{l}103.1-10 \\
107.5-11\end{array}$ & $\begin{array}{l}4.4 \\
4.4\end{array}$ & $\begin{array}{l}4.38 \\
4.53\end{array}$ & $\begin{array}{r}99.5 \\
103.0\end{array}$ \\
\hline 27 & 21 & & & & 4.4 & 4.27 & $\begin{array}{r}103.0 \\
97.0\end{array}$ \\
\hline $28^{\circ}$ & 21 & & & & 3. & & 106.3 \\
\hline 29 & 21 & & & & 3. & & 102.9 \\
\hline & 21 & & & & 3 & & 108 \\
\hline 31 & 21 & & & & & & \\
\hline 32 & 21 & 1851 & & & & & \\
\hline 33 & 21 & 1953 & 31 & & & & \\
\hline 34 & 21 & 21 & & & & & \\
\hline 35 & 21 & 220 & & & & & 112.0 \\
\hline & ${ }_{22}^{21}$ & ${ }^{231}$ & $\begin{array}{l}3192.3 . \\
3194.8\end{array}$ & 14 & 2.5 & 2.53 & 101.2 \\
\hline 38 & 22 & 02 & 8.8 & $\begin{array}{l}143.8-14 \\
145.8\end{array}$ & $\begin{array}{l}2.5 \\
1.5\end{array}$ & $\begin{array}{l}2.069 \\
2.01\end{array}$ & $\begin{array}{l}\begin{array}{l}107.6 \\
134.0\end{array} \\
\text {. }\end{array}$ \\
\hline 39 & 22 & & & & 3.0 & 2. & 96.0 \\
\hline 40 & 22 & & & & 2. & 2.7 & 108.8 \\
\hline 41 & 22 & & & & 3. & 3. & 110.3 \\
\hline 42 & 22 & 0712 & & & 2.5 & 2.65 & 106.0 \\
\hline & 22 & 0821 & $3209.8-3212.8$ & $158.3-161.3$ & 3.0 & 2.86 & 95.3 \\
\hline
\end{tabular}

Table 1. (Continued).

\begin{tabular}{|c|c|c|c|c|c|c|c|}
\hline $\begin{array}{l}\text { Core } \\
\text { No. }\end{array}$ & $\begin{array}{c}\text { Date } \\
\text { (August } \\
\text { 1979) }\end{array}$ & $\begin{array}{l}\text { Time } \\
\text { (hr.) }\end{array}$ & $\begin{array}{l}\text { Depth from } \\
\text { Drill Floor } \\
\text { (m) } \\
\text { Top Bottom }\end{array}$ & $\begin{array}{l}\text { Depth below } \\
\text { Seafloor } \\
\text { (m) } \\
\text { Top Bottom }\end{array}$ & $\begin{array}{l}\text { Length } \\
\text { Cored } \\
\text { (m) }\end{array}$ & $\begin{array}{l}\begin{array}{c}\text { Length } \\
\text { Recovered } \\
\text { (m) }\end{array}\end{array}$ & $\begin{array}{c}\text { Recovery } \\
(\%)\end{array}$ \\
\hline \multicolumn{8}{|c|}{ Hole 502A (cont) } \\
\hline 44 & 22 & 0929 & $3212.8-3215.3$ & $161.3-163.8$ & 2.5 & 2.47 & 98.8 \\
\hline 45 & 22 & 1028 & 3215.3-3217.8 & $163.8-166.3$ & 2.5 & 2.47 & 98.8 \\
\hline 46 & 22 & 1134 & $3217.8-3219.8$ & $166.3-168.3$ & 2.0 & 2.26 & 113.0 \\
\hline 47 & 22 & 1235 & $3219.8-3222.8$ & $168.3-171.3$ & 3.0 & 3.34 & 111.3 \\
\hline 48 & 22 & 1341 & $3222.8-3224.8$ & $171.3-173.3$ & 2.0 & 1.94 & 97.0 \\
\hline 49 & 22 & 1444 & $3224.8-3226.8$ & $173.3-175.3$ & 2.0 & 0.00 & 0.0 \\
\hline so & 22 & 1546 & $3226.8-3229.8$ & $175.3-178.3$ & 3.0 & 2.58 & 86.0 \\
\hline 51 & 22 & 1654 & $3229.8-3232.3$ & $178.3-180.8$ & 2.5 & 2.17 & $\begin{array}{l}72.3 \\
885\end{array}$ \\
\hline 52 & 22 & $\begin{array}{l}1809 \\
1019\end{array}$ & $3232.3-3234.3$ & $180.8-182.8$ & 2.0 & 1.71 & 85.5 \\
\hline $\begin{array}{l}53 \\
54\end{array}$ & 22 & $\begin{array}{l}1919 \\
2014\end{array}$ & $\begin{array}{l}3234.3-3236.3 \\
32323.3238 .8\end{array}$ & $\begin{array}{l}182.8-184.8 \\
184.8-18.3\end{array}$ & 2.0 & $\begin{array}{l}1.54 \\
2.48\end{array}$ & 77.0 \\
\hline 55 & 22 & $\begin{array}{l}2014 \\
2125\end{array}$ & $\begin{array}{l}32263.35-32388.8 \\
3238.8-3240.8\end{array}$ & $\begin{array}{l}184.8-187.3 \\
187.3-189.3\end{array}$ & $\begin{array}{l}2.5 \\
2.0\end{array}$ & $\begin{array}{l}2.48 \\
2.11\end{array}$ & $\begin{array}{c}99.2 \\
105.5\end{array}$ \\
\hline 56 & 22 & 2225 & $3240.8-3242.8$ & $189.3-191.3$ & 2.0 & 2.15 & 107.5 \\
\hline 57 & 22 & 2329 & $3242.8-3244.8$ & $191.3-193.3$ & 2.0 & 1.96 & 98.0 \\
\hline 58 & 23 & 0037 & $3244.8-3246.8$ & $193.3-195.3$ & 2.0 & 2.01 & 100.5 \\
\hline 59 & 23 & 0144 & $3246.8-3248.8$ & $195.3-197.3$ & 2.0 & 0.60 & 30.0 \\
\hline 60 & 23 & 0257 & $3248.8-3250.8$ & & & & 93.5 \\
\hline 61 & 23 & 0409 & $3250.8-3252.8$ & & & & 75.5 \\
\hline 62 & 23 & 0535 & & & & & 25.5 \\
\hline 63 & 23 & 0647 & $3254.8-3256.8$ & & 2.0 & & 80.8 \\
\hline 64 & 23 & 0815 & $\begin{array}{l}3256.8-3258.8 \\
3258.82068\end{array}$ & $\begin{array}{l}205.3-207.3 \\
207.3-20.3\end{array}$ & 2.0 & 0.00 & 0.0 \\
\hline 66 & $\begin{array}{l}23 \\
23\end{array}$ & $\begin{array}{l}0924 \\
1039\end{array}$ & $\begin{array}{l}3258.8-3260.8 \\
3360 .-326.8\end{array}$ & $\begin{array}{r}207.3-209.3 \\
209.3-21.3\end{array}$ & $\begin{array}{l}2.0 \\
2.0\end{array}$ & $\begin{array}{l}2.36 \\
1.84\end{array}$ & $\begin{array}{l}118.0 \\
992.0\end{array}$ \\
\hline 67 & 23 & $\begin{array}{l}1039 \\
1154\end{array}$ & $\begin{array}{l}32200.8-3202.8 \\
3262.8-3264.3\end{array}$ & $211.3-212.8$ & $\begin{array}{l}2.0 \\
1.5\end{array}$ & $\begin{array}{l}1.84 \\
1.02\end{array}$ & $\begin{array}{l}9.2 .0 \\
68.0\end{array}$ \\
\hline 68 & 23 & 1308 & $3264.3-3266.3$ & $212.8-215.0$ & 2.0 & 2.20 & 110.0 \\
\hline Total & & & & & 215.00 & 176.50 & 82.2 \\
\hline \multicolumn{8}{|c|}{ Hole 502B } \\
\hline 1 & 23 & & & & 1.75 & & \\
\hline & 23 & 1650 & & & 4. & & \\
\hline & 23 & 1756 & 3058. & 6.15 & & & \\
\hline & 23 & 1859 & $3063.2-3$ & & & & 99.5 \\
\hline & 23 & & $3067.6-3072.0$ & & & & 91.6 \\
\hline 6 & 23 & & 3072 & & 4.4 & & 100.0 \\
\hline 7 & 23 & 2202 & $3076.4-30$ & & 4.4 & 4.65 & 105.7 \\
\hline 8 & 23 & 2324 & $3080.8-3 c$ & & 4. & & 83.2 \\
\hline 9 & 24 & $\infty$ & 3085. & & & & 82.0 \\
\hline 10 & 24 & 02 & & & & & \\
\hline 11 & 24 & 0407 & & & & & .5 \\
\hline 12 & 24 & 0617 & 3098. & & & & 80.9 \\
\hline 13 & 24 & 0713 & $3102.8-3$ & 50.1 & 4.4 & & 101.4 \\
\hline 14 & 24 & 0824 & 3107.2 & 54.5 & .4 & & $\begin{array}{c}97.3 \\
58.0\end{array}$ \\
\hline${ }_{16}^{15}$ & 24 & 0918 & 3111.6 & $58.95-6$ & 4.4 & & 58.0 \\
\hline $\begin{array}{l}16 \\
17\end{array}$ & ${ }_{24}^{24}$ & $\begin{array}{l}1016 \\
1129\end{array}$ & & $63.35-6$ & $\begin{array}{l}4.4 \\
4.4\end{array}$ & $\begin{array}{l}1.23 \\
4.20\end{array}$ & $\begin{array}{l}28.0 \\
95.5\end{array}$ \\
\hline 18 & 24 & ${ }_{12}^{112}$ & & & $\begin{array}{l}4.4 \\
4.4\end{array}$ & & $\begin{array}{l}95.3 \\
99.3\end{array}$ \\
\hline 19 & 24 & 1334 & & & & & .5 \\
\hline 20 & 24 & & & & & & 103.4 \\
\hline 21 & 24 & 1542 & & & 4. & 4.32 & 98.2 \\
\hline 22 & 24 & 1642 & & & & & 105.0 \\
\hline 23 & 25 & 0330 & $3146.8-3151.2$ & $94.15-98.55$ & 4.4 & 3.49 & 79.3 \\
\hline Total & & & & & 98.55 & 86.31 & 87.6 \\
\hline
\end{tabular}

Hole $502 \mathrm{C}$

\begin{tabular}{|c|c|c|c|c|c|c|c|}
\hline 1 & 25 & 1243 & $3083.5-3087.9$ & $32.0-36.4$ & 4.4 & 4.42 & 100.4 \\
\hline & 25 & 1343 & $3087.9-3092.3$ & $36.4-40.8$ & 4.4 & 4.47 & 101.6 \\
\hline & 25 & 1443 & 3092.3-3096.7 & $40.8-45.2$ & 4.4 & 3.67 & 83.4 \\
\hline 4 & 25 & 1545 & $3096.7-3101.1$ & $45.2-49.6$ & 4.4 & 1.65 & \\
\hline & 25 & 1645 & $3101.1-3105.5$ & $49.6-54.0$ & 4.4 & 4.28 & 97.3 \\
\hline & 25 & 1749 & $3105.5-3109.9$ & $54.0-58.4$ & 4.4 & 4.42 & 100.4 \\
\hline & 25 & 1852 & $3109.9-3114.3$ & $58.4-62.8$ & 4.4 & 0.76 & 17.3 \\
\hline 8 & 25 & 1958 & $3114.3-3118.7$ & $62.8-67.2$ & 4.4 & 4.52 & 102.7 \\
\hline & 25 & 2110 & $3118.7-3123.1$ & $67.2-71.6$ & 4.4 & $4.4 \mathrm{I}$ & 100.2 \\
\hline 10 & 25 & 2213 & $3123.1-3127.5$ & $71.6-76.0$ & 4.4 & 4.55 & 103.4 \\
\hline $\begin{array}{ll}11 \\
12\end{array}$ & 25 & 2312 & $3127.5-3131.9$ & 76.0-80.4 & 4.4 & 4.50 & 102.3 \\
\hline $\begin{array}{l}12 \\
13\end{array}$ & ${ }_{26}^{26}$ & $\begin{array}{l}0026 \\
0129\end{array}$ & $\begin{array}{l}3131.9-3136.3 \\
3136,3-3140.7\end{array}$ & $\begin{array}{l}80.4-84.8 \\
84.8-89.2\end{array}$ & $\begin{array}{l}4.4 \\
4.4\end{array}$ & $\begin{array}{l}2.01 \\
468\end{array}$ & 45.7 \\
\hline 14 & 26 & $\begin{array}{l}0129 \\
2039\end{array}$ & $\begin{array}{l}3136.3-3140.7 \\
3140.7-3145.1\end{array}$ & $\begin{array}{l}84.8-8-9.2 \\
89.2-93.6\end{array}$ & $\begin{array}{l}4.4 \\
4.4\end{array}$ & $\begin{array}{l}4.68 \\
4.60\end{array}$ & $\begin{array}{l}106.4 \\
104.5\end{array}$ \\
\hline 15 & 26 & 0353 & $3145,1-3149.5$ & $\begin{array}{l}89.2-93.6 .6 \\
93.6-98.0\end{array}$ & $\begin{array}{l}4.4 \\
4.4\end{array}$ & $\begin{array}{l}4.60 \\
4.65\end{array}$ & $\begin{array}{l}105.7 \\
105.3\end{array}$ \\
\hline 16 & 26 & 0459 & $3149.5-3153.9$ & $98.0-102.4$ & 4.4 & 4.57 & 103.9 \\
\hline 17 & 26 & 0620 & $3153.9-3158.3$ & $102.4-106.8$ & 4.4 & 4.48 & 101.8 \\
\hline 18 & 26 & 0727 & $3158,3-3162.7$ & $106.8-111.2$ & 4.4 & 4.06 & 92.3 \\
\hline 19 & 26 & 0830 & $3162.7-3167.1$ & $111.2-115.6$ & 4.4 & 2.03 & 46.1 \\
\hline 20 & 26 & 0942 & $3167.1-3171.5$ & $115.6-120.0$ & 4.4 & 3.68 & 83.6 \\
\hline 21 & 26 & 1044 & $3171.5-3175.9$ & $120.0-124.4$ & 4.4 & 3.09 & 70.2 \\
\hline 22 & 26 & 1137 & $3175.9-3176.9$ & $124.4-125.4$ & 1.0 & 0.89 & 89.0 \\
\hline 23 & ${ }_{26}^{26}$ & $\begin{array}{l}1257 \\
1526\end{array}$ & $\begin{array}{l}3176.9-3181.3 \\
3181385\end{array}$ & $\begin{array}{l}125.4-129.8 \\
\end{array}$ & 4.4 & 4.29 & 97.5 \\
\hline & 26 & $\begin{array}{l}1526 \\
1627\end{array}$ & $\begin{array}{l}3181.3-3185.7 \\
331857-3188.7\end{array}$ & $\begin{array}{l}129.8-134.2 \\
134.2-137.2\end{array}$ & $\begin{array}{l}4.4 \\
3.0\end{array}$ & 3.29 & $\begin{array}{l}74.8 \\
-14.3\end{array}$ \\
\hline 26 & 26 & $\begin{array}{l}1027 \\
1749\end{array}$ & $3188.7-3192.2$ & $137.2-140.7$ & 3.5 & 3.40 & $\begin{array}{l}41.3 \\
97.1\end{array}$ \\
\hline 27 & 26 & 1857 & $3192,2-3195.7$ & $140.7-144.2$ & 3.5 & 3.03 & 96.6 \\
\hline & Wash & & $3195.7-3261.7$ & $144.2-210.2$ & & & \\
\hline 28 & 26 & 2236 & $3261.7-3264.7$ & $210.2-213.2$ & 3.0 & 3.01 & 100.3 \\
\hline 29 & 26 & 2350 & $3264.7-3266.7$ & $213.2-2$ & 2.0 & 2.02 & 101.0 \\
\hline 30 & 27 & 0107 & $3266.7-3268.2$ & $215.2-2$ & 1.5 & 1.6 & 107.3 \\
\hline & 27 & 0211 & $3268.2-3270.7$ & $216.7-21$ & 2.5 & 2.3. & 95.2 \\
\hline 32 & 27 & 0315 & $3270.7-3273.2$ & $219.2-22$ & 2.5 & 2.19 & 87.6 \\
\hline 33 & 27 & 0410 & $\begin{array}{l}3273.2-3275.2 \\
3775\end{array}$ & $221.7-223.7$ & 2.0 & 2.26 & 113.0 \\
\hline 35 & 27 & 0520 & $3275.2-3277.2$ & $223.7-225.7$ & 2.0 & 2.11 & 105.5 \\
\hline 36 & 27 & $\begin{array}{l}0029 \\
0742\end{array}$ & $3278.2-3279.2$ & $226.7-227.7$ & 1.0 & 0.48 & $\begin{array}{l}93.0 \\
48.0\end{array}$ \\
\hline 37 & 27 & 0920 & $3279.2-3280.2$ & $227.7-227.81$ & 1.0 & 0.11 & 11.0 \\
\hline & & & & & $\begin{array}{l}130.7 \\
227.81\end{array}$ & 112.7 & 86.2 \\
\hline
\end{tabular}


Table 2. Lithostratigraphic summary for Site 502.

\begin{tabular}{|c|c|c|c|c|}
\hline Unit & Hole/Core & $\begin{array}{l}\text { Sub-bottom } \\
\text { Depth }(\mathrm{m})\end{array}$ & Age & Description \\
\hline A & $\begin{array}{l}502,1 \text { to } 3 \\
502 \mathrm{~A}, 1 \text { to } 3 \\
502 \mathrm{~B}, 1 \text { to } 2\end{array}$ & $0-7$ & $\begin{array}{l}\text { Holocene-late } \\
\text { Pleistocene }\end{array}$ & $\begin{array}{l}\text { Foraminifer-bearing nannofossil marl; yellowish } \\
\text { brown to light brownish gray; generally } \\
\text { structureless. }\end{array}$ \\
\hline B & $\begin{array}{l}502,3 \text { to } 25-27 \\
502 \mathrm{~A}, 3 \text { to } 24-27 \\
502 \mathrm{~B}, 2 \text { to } 23 \\
502 \mathrm{C}, 1 \text { to } 16-18\end{array}$ & $7-110$ & $\begin{array}{l}\text { late Pleistocene- } \\
\text { early Pliocene }\end{array}$ & $\begin{array}{l}\text { Foraminifer-bearing nannofossil marl; gray to } \\
\text { olive gray; generally structureless with occa- } \\
\text { sional ash beds, foraminifer cycles and } \\
\text { foraminifer content greater than } 10 \% \text {. }\end{array}$ \\
\hline C & $\begin{array}{l}502,25-27 \text { to } 50 \\
502 \mathrm{~A}, 24-27 \text { to } 67 \\
502 \mathrm{C}, 16-18 \text { to } 27\end{array}$ & $110-210$ & $\begin{array}{l}\text { early Pliocene- } \\
\text { Miocene }\end{array}$ & $\begin{array}{l}\text { Foraminifer-bearing nannofossil marl; to } \\
\text { calcareous clays, light gray to olive gray to } \\
\text { dark greenish gray; foraminiferal content less } \\
\text { than } 10 \% \text {; pyritic ash layers and distinct } \\
\text { burrowing are common. }\end{array}$ \\
\hline D & $\begin{array}{l}\text { S02A, } 68 \\
502 \mathrm{C}, 28 \text { to } 37\end{array}$ & $210-228$ & late Miocene & $\begin{array}{l}\text { Calcareous and ash-bearing clay, pale green to } \\
\text { grayish green; pyritic ash layers are common } \\
\text { and biosiliceous remains are present. }\end{array}$ \\
\hline
\end{tabular}

abundant illite, and common amounts of chlorite and kaolinite (see Zimmerman, this volume). Calcium carbonate content ranges from 35 to $60 \%$ (see Gardner, this volume).

\section{Unit B (7-110 m sub-bottom)}

The upper contact of Unit B with Unit A is transitional, based on a color gradation in Core $3 \mathrm{~A}$, but is marked by cyclical color variations in Holes 502 and 502B. The lower boundary is marked by a decrease in the content of foraminifers to below $10 \%$. The lower contact is located between Cores 25 and 27 in Hole 502 and between Cores 24 and 27 in Hole 502A. The base of the unit in Hole 502C is in Core 18 at approximately 109 meters (Table 2).

The sediment of Unit B is predominantly foraminiferbearing nannofossil marl and nannofossil marl with minor amounts of nannofossil-bearing foraminifer marl. Colors range from gray to olive and light olive gray. The sediment is generally homogeneous with few primary structures, faintly burrowed and mottled, and exhibits indistinct black and grayish green lamina. The upper 60 meters has irregular cycles of foraminifer-rich zones.

Major constituents (Table 3) of Unit B are abundant nannofossils and clay. Foraminifers are abundant to common; estimates of foraminifer content range from 35 to $10 \%$, but as the basal contact is approached, abundances fall in the lower part of the range. Calcium carbonate content ranges from 35 to $55 \%$. Quartz, heavy minerals, and micronodules are present in trace amounts, and zeolite minerals occur in rare to trace amounts. Rare pyrite is dispersed throughout and occasionally concentrated as nodules. Glass shards are often found dispersed in rare amounts, and bedded vitric ashes (1-8 $\mathrm{cm}$ thick) are present but not abundant (Cores 502-8 and $502 \mathrm{~A}-10$ ). The coarse fraction mineral component is similar to that found in Unit A, with the addition of green pellets (glauconite, celadonite), phillipsite, and pyrite. The lower half of Unit B (approximately $60-110 \mathrm{~m}$ sub-bottom) also contains abundant chitoniferous biogenic material (Fig. 5). X-ray diffraction studies show the occasional presence of rare amounts of phillipsite and clinoptilolite. The clay mineral component consists of abundant montmorillonite with common amounts of illite, chlorite, and kaolinite. Mixed layer clays are present in rare amounts.

\section{Unit C (110-210 m sub-bottom)}

The upper contact of Unit C is marked by a decrease in foraminifer content to below $10 \%$. The lower boundary is placed at the first occurrence of siliceous microfossils in Cores 502C-28 $(210 \mathrm{~m})$ and 502A-68 $(215 \mathrm{~m})$.

The sediment consists of foraminifer-bearing nannofossil marl in the upper portion grading into calcareous clay and ash and pyrite-bearing clay in the lower section. Colors in the upper section are gray to light gray but graduafly change to olive gray and dark greenish gray in the lower section. The colors vary irregularly but become consistently darker with depth. Cyclical color patterns become prevalent with depth through this unit.

The marl is structureless but faintly mottled and burrowed in the upper section with only an occasional area of distinct burrows where changes in sediment color allow contrast between the burrows and the surrounding sediment. Burrowing is more intense in the lower section, with Zoophycos common in the middle to lower section. Foraminifers are visible but very sparsely scattered.

The major constituent (Table 3 ) of Unit $C$ is clay that is abundant and shows a gradual increase with depth. Nannofossils are common throughout and are sometimes abundant in the upper sections. Foraminifers range from trace to common amounts but are restricted to less than $10 \%$ throughout. Quartz and heavy minerals are persistent but in trace amounts. Pyrite nodules are randomly distributed, whereas dispersed pyrite crystals are present throughout in common to trace amounts. Ash layers $1-8 \mathrm{~cm}$ thick, some of which are partially devitrified, are more common in this unit than in the sediment above. They increase in abundance with depth and consistently occur with abundant concentrations of pyrite and/or zeolites. Abundant quartz, potash and plagioclase feldspar, and hornblende occur in pulses in the coarse fraction. Volcanic glass, a green mineral that may be celadonite, and pyrite are common throughout. Montmorillonite dominates the clay mineral component, but illite and kaolinite are common and chlorite common to rare. X-ray diffraction studies show occasional small amounts of clinoptilolite.

\section{Unit D (210-227 m sub-bottom)}

Unit $\mathrm{D}$ is represented by the bottom 18 meters of the recovered section. The upper contact is defined by the 
appearance of siliceous microfossils at 210 to 213 meters in Cores 502C-28 and 502A-68, respectively. This unit consists of calcareous and ash-bearing clay interspersed with black beds of pyrite and ash (1-10 cm thick). Colors range from pale green to grayish green and grayish blue green and are often arranged in cyclic patterns. The sediment is intensely burrowed and mottled in various shades of green and light olive brown.

Clay is a dominant to abundant constituent of this unit. Carbonate nannofossils and foraminifers are common to rare and generally constitute less than $10 \%$ of the total sediment. Radiolarians, sponge spicules, and, more rarely, diatoms are persistent throughout in common to rare amounts. Heavy minerals are found only in trace amounts, and zeolites are rare. Dispersed pyrite and shards of volcanic glass are common to rare throughout and often occur together in black beds of pyrite and ash mixtures. The clay mineral component is dominated by montmorillonite; illite and kaolinite occur in common to rare abundance, whereas chlorite and zeolites are rare.

\section{Discussion}

Volcanic ash layers are found consistently in Units C and D and less frequently in Unit B (Fig. 5). They vary from approximately 1 to $5 \mathrm{~cm}$ in thickness but may be as thick as $10 \mathrm{~cm}$. Their lower contacts are relatively sharp but bioturbated, whereas upper contacts are gradational, extending as much as $10 \mathrm{~cm}$ above the ash bed. The ash layers are often black to olive and are almost exclusively a mixture of light-colored glass shards and abundant pyrite. Trace to rare amounts of celadonite and dark glass are also present. Euhedral crystals of zeolite are common in the gradational zone above the ash or as separate laminae and suggest a high degree of diagenetic alteration. Devitrification of the volcanic shards has occurred in some instances (Cores 502A-46, 52,57 , and 58). Dispersed ash shards commonly occur in Units C and D and in the upper portion of Unit B (see Ledbetter, this volume, for details of ash abundance).

Two doublets of ash are of special significance; both consist of two separate but closely spaced ash layers. These doublets are easily recognized and provide distinctive lithologic horizons for correlation between holes. Each doublet consists of a thin ash layer approximately $10 \mathrm{~cm}$ below a larger ash bed (Fig. 6). The first set in Cores 502-32, 502A-32, and 502C-23 occurs at about 132,130 , and 128 meters sub-bottom, respectively. The second doublet is found in Cores 502-40 and 502B-44 at sub-bottom depths of about 166 and 162 meters, respectively. All other ash layers are single beds or irregular concentrations of volcanic shards or zeolite minerals. A distinctive layer of light gray ash occurs in Cores 502-8 and 502B-8 at about 30 meters sub-bottom. Ash occurrence was occasionally noted in the upper section at Site 154 , but correlation between Site 154 and 502 is impossible because ash layers were thoroughly disturbed by rotary drilling at Site 154 (Edgar, Saunders, et al., 1973).

Chitoniferous biogenic material (Fig. 7) was found scattered in trace abundances throughout the section. These biogenic "parts" were photographed from resid- ual sediment that was acidified to remove calcareous material and then sieved through a $63-\mathrm{mm}$ sieve. Material similar to that shown in Figure 7 was found only in sediment that contains appreciable amounts of pyrite. The most common type is identified as a squid hook (Figure 7E), even though the one shown in Figure 7E is from Site 503 in the equatorial Pacific. Material of a similar nature has been noted from Sites 494, 496, 497, 499 , and 500 on the inner slope and floor of the Middle America Trench and at Site 251 in the southwestern Indian Ocean (J. Westberg, personal communication).

We attempted to visually correlate relative sediment texture between holes. A "coarse" texture reflects an abundance of foraminifers that are generally visible. Figure 8 shows areas in which the foraminiferal component was either prominent or absent. In general, prominent to coarse bands occur only above about 60 meters subbottom, and the coarse foraminifer component is rare beneath about 110 meters sub-bottom, the lower boundary of Unit B.

Colors in the top 7 meters of the sequence are banded in shades of brown and yellow (Fig. 8). This zone represents oxidized conditions, and smear slide observations indicate that micronodules (possibly $\mathrm{Fe}-\mathrm{Mn}$ ) are present. The greens and grays below 7 meters sub-bottom indicate reduced conditions where pyrite becomes ubiquitous in at least trace amounts, and below 20 meters micronodules disappear. The sediment between 7 meters and about 50 meters is generally olive gray and olive, and below 50 meters gray and greenish gray become prominent. The sediment darkens with depth; the dominant color becomes green to dark green at about 200 meters sub-bottom.

The texture and color changes do not correlate in detail between holes but do outline areas of similar cyclicity on a broad scale. This lack of correlation may be due in part to localized effects that cause these features to lack significant lateral extension.

Carbonate content decreases irregularly with depth in each hole, with an average of 40 to $50 \%$ in Unit A to less than $20 \%$ in Unit D (Fig. 9). Well-defined cyclic variations of carbonate are superimposed on this trend of decreased carbonate with depth. Gardner (this volume) presents a detailed discussion of the carbonate stratigraphy. Bulk accumulation rates for the carbonate and noncarbonate fractions suggest that the decrease is caused primarily by a large terrigenous and volcanic influx in the lower sections and a gradual decrease of this component with time (see Accumulation Rates section for details).

Several observations aboard ship and during subsequent studies suggest that an abrupt change in sediment type occurs below 200 to 210 meters sub-bottom. Sediment below this level is characterized by the presence of siliceous microfossils, high percentages of smectite relative to the other clay minerals, poor smectite crystallinity, low ratio of quartz to plagioclase, low bulk density, high water content, low carbonate content, and high porosity. Sediment above 200 to 210 meters subbottom has just the opposite characteristics. Also, a shift in $\delta^{13} \mathrm{C}$ that can be correlated to a similar event 


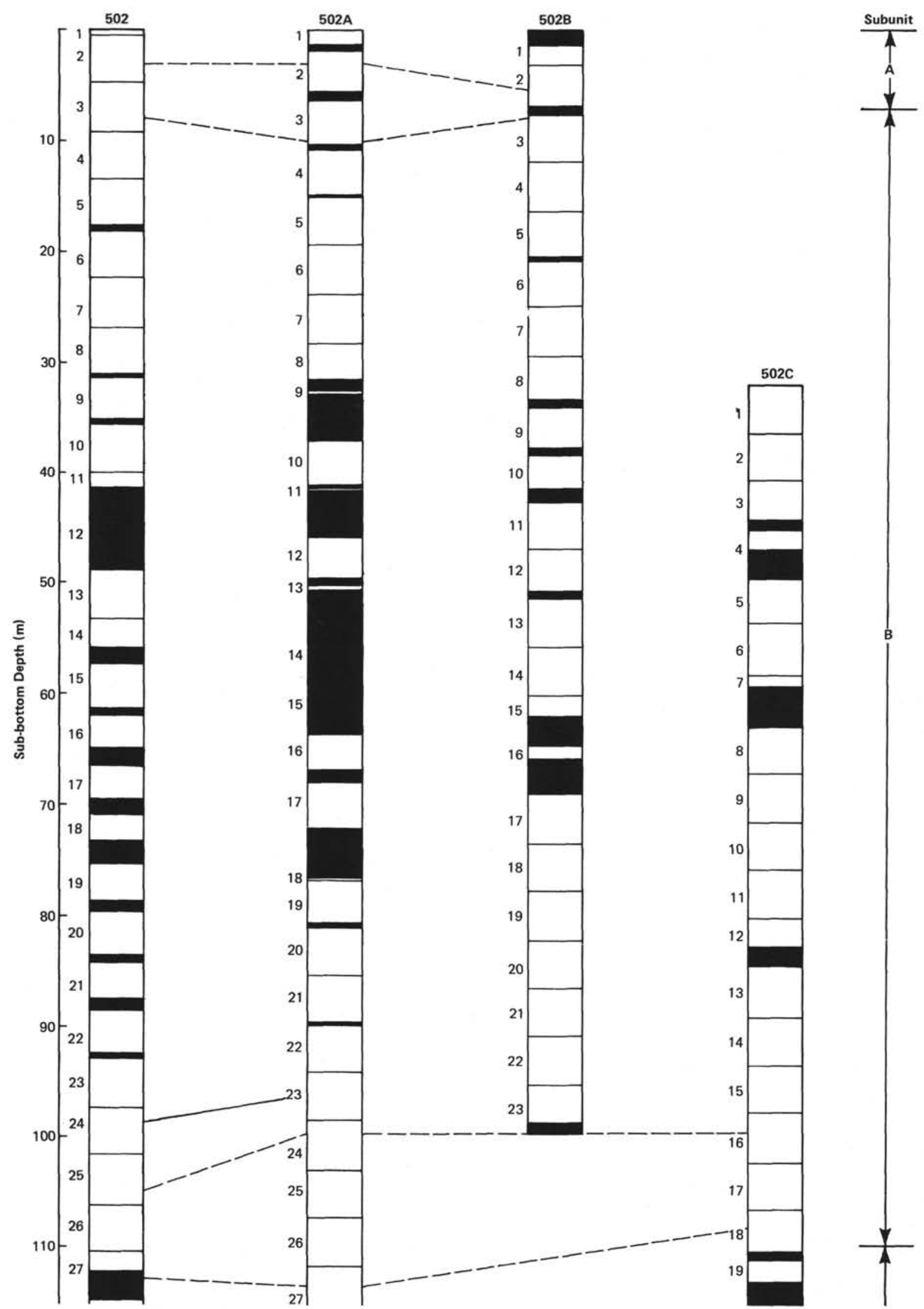

Figure 5. Correlation of megascopic volcanic ash layers between Holes 502, 502A, 502B, and 502C. Note ash doublets near 130 and 160 meters sub-bottom. Lithologic units are given in the righthand margin. Areas of no recovery are shown by black zones. Dashed lines are problematic correlations. 


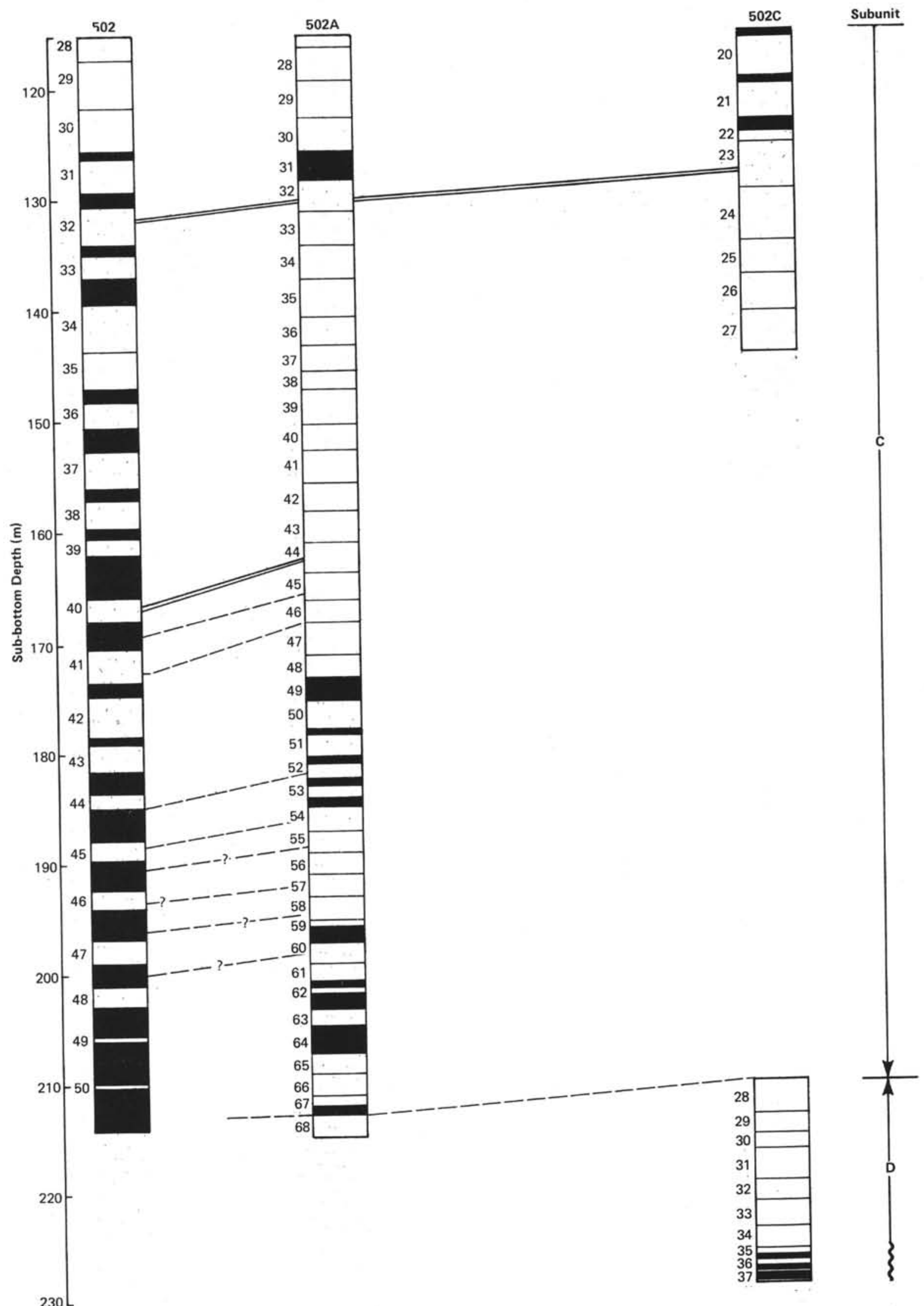

Figure 5. (Continued). 


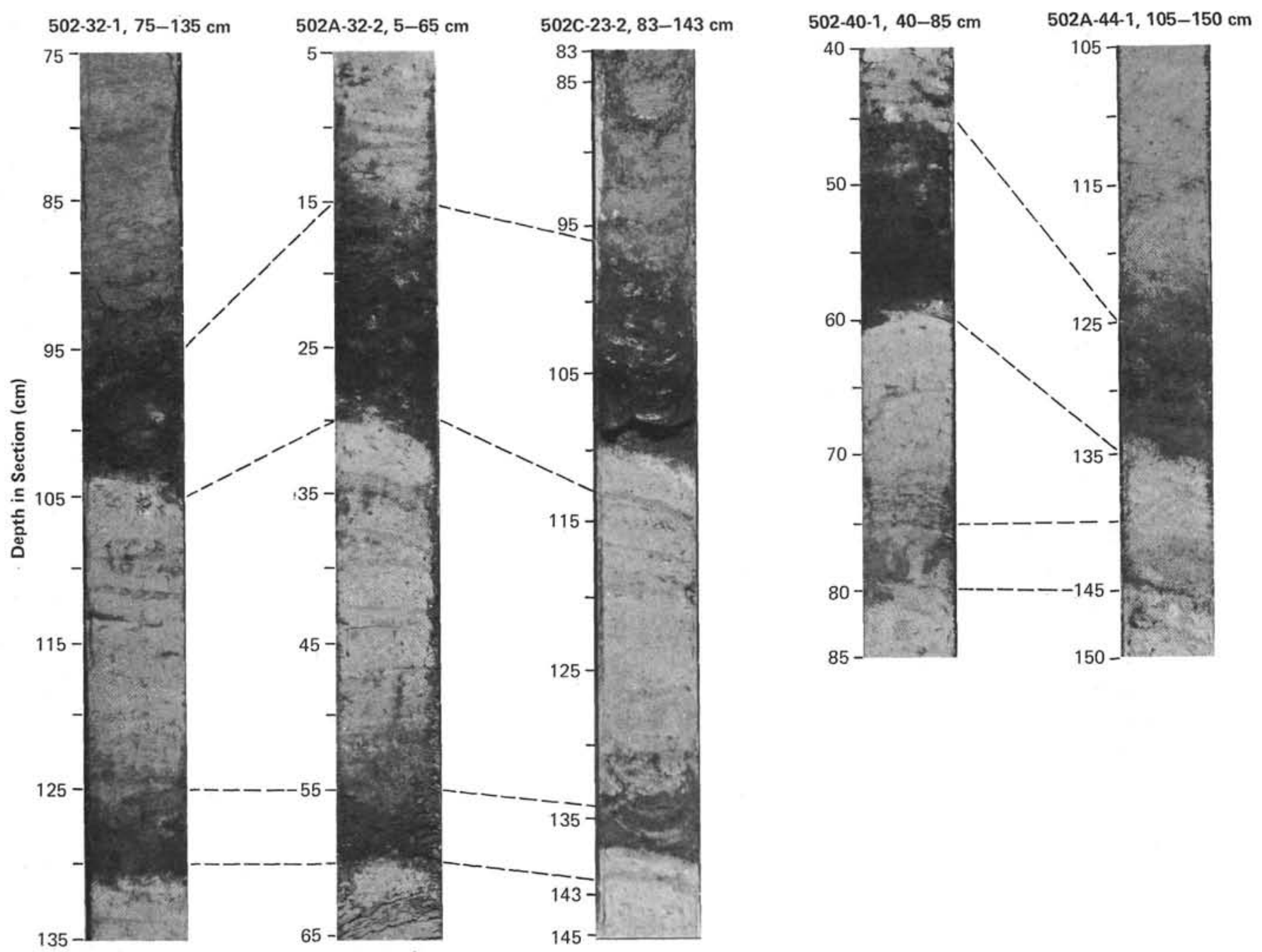

Figure 6. Photograph and location within holes of ash doublets used for correlation between holes.

dated 6.5 Ma (Keigwin, this volume) occurs between 196 and 199 meters sub-bottom (Keigwin, this volume). The section below this depth is similar to a "Pacific-type" marine sediment (Heath, 1969), whereas the section above this level is similar to an "Atlantic-type" sediment with terrigenous components.

\section{PHYSICAL PROPERTIES}

Since its inception, DSDP has maintained a program to measure physical properties of deep sea sediment to complement the geological, geophysical, and technological investigations carried out aboard Glomar Challenger. Unfortunately, rotation of the drill bit around the sediment often results in severe disturbance of these physical properties (Demars and Nacci, 1978; Lee, 1973). The HPC, however, recovers a continuous section of relatively undisturbed sediment to a maximum depth of greater than 200 meters sub-bottom. Therefore we undertook a detailed program of physical property analyses on Leg 68. The major objectives of this program were to understand the downcore variations in physical properties and relate them to geologic and paleoceanographic parameters, observe the behavior of a compacting sediment column, establish the engineering limits of the HPC and the degree and nature of disturbance it causes, and to use the physical properties data to help interpret the seismic records collected in the region.

The physical properties determined at Site 502 include shear strength; sonic velocity-both through the liner and on chunk samples; wet-bulk density, grain density, porosity, and water content on chunk samples; and saturated bulk density by the continuous scan gammaray attenuation porosity evaluation (GRAPE). The interested reader is referred to Mayer (this volume) for a full discussion of the physical properties of the recovered sediment.

We found a general trend of increased shear strength with depth (Fig. 10) that is the result of increased overburden and compaction. Calculated effective overburden pressure, derived from saturated bulk density data, is $11,500 \mathrm{~g} / \mathrm{cm}^{2}$ at 206 meters sub-bottom (Mayer, this volume). Shear strength values range from near zero in the uppermost sediment to a maximum of over $3000 \mathrm{~g} /$ $\mathrm{cm}^{2}$ at 194 meters. A rapid increase in shear strength occurs at about 88 meters and between 110 and 130 meters (Fig. 10). High-frequency fluctuations of shear strength (1-2 m wavelengths) occur in all four holes and may reflect subtle changes in lithology. Shear strength values 


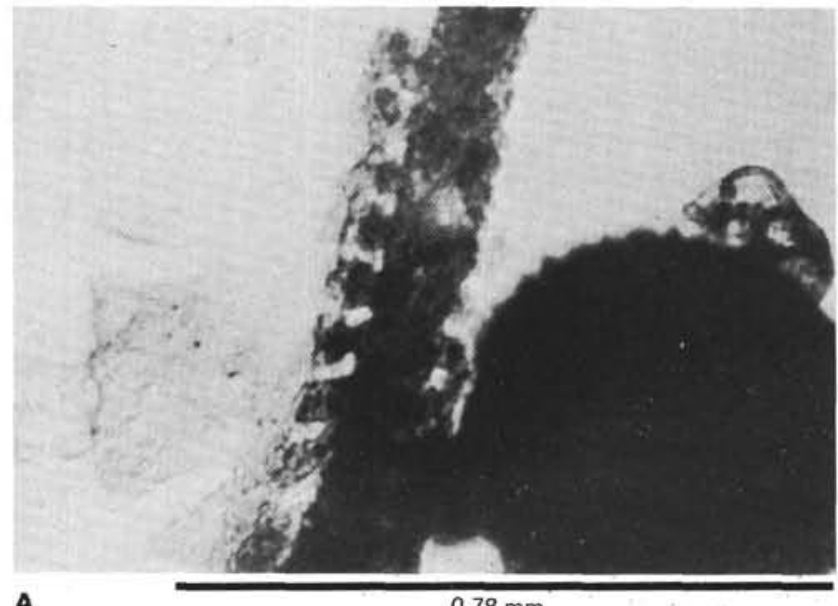

A

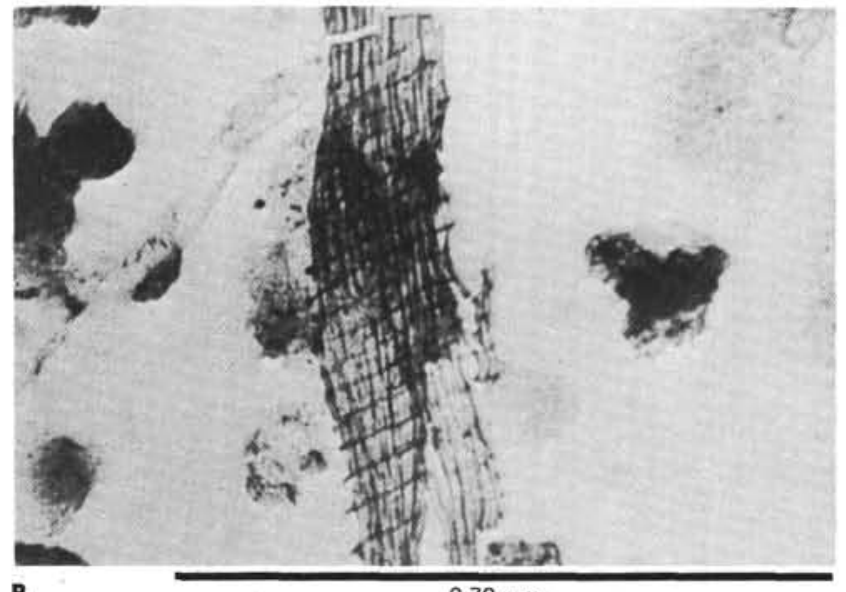

B

$0.78 \mathrm{~mm}$

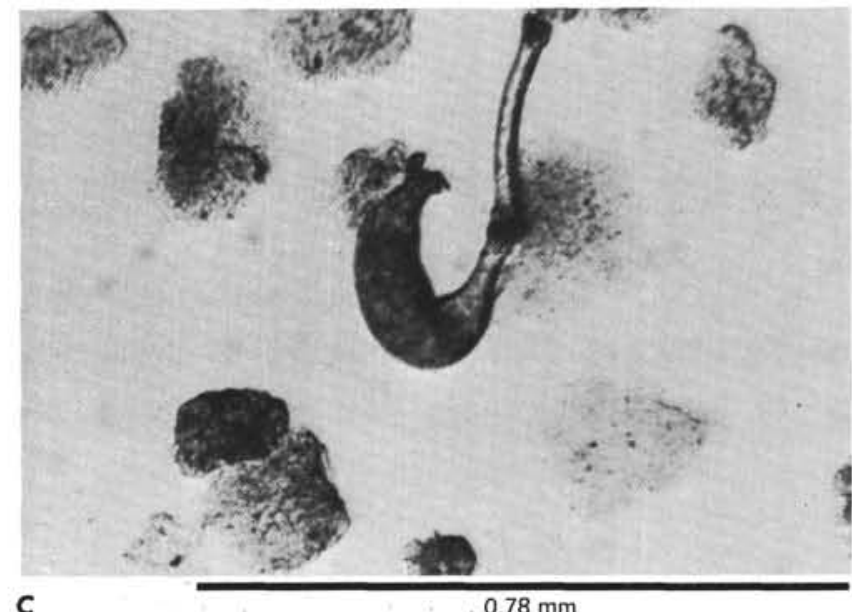

C

$0.78 \mathrm{~mm}$

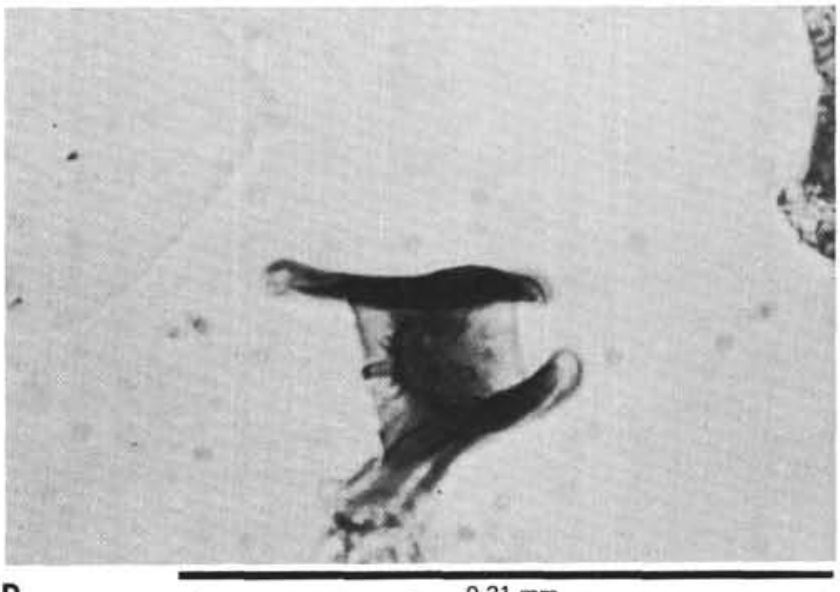

$0.31 \mathrm{~mm}$

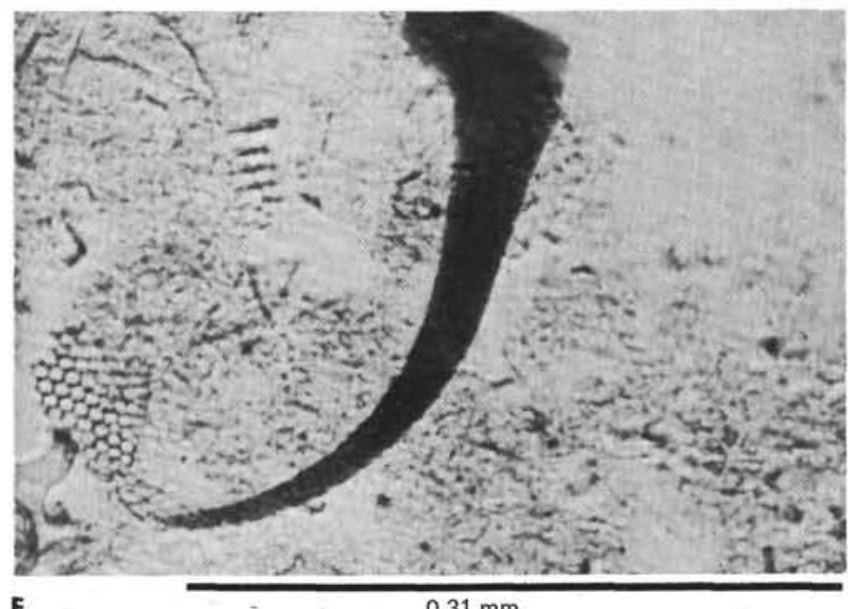

E

$0.31 \mathrm{~mm}$

Figure 7. Photographs of biogenic parts found in sediment from Sites 502 and 503. A. Sample 502A-8-2, approx. 30 meters sub-bottom. Unidentified. B. Sample 502A-16-2, approx. 65 meters sub-bottom. C. B. Miller (personal communication) suggests a bit of wood or other vegetable fiber, whereas A. Hutchinson (personal communication) identified it as a piece of chitonous tintinid lorica (test). C. Sample 502A-17-3, approx. 71 meters sub-bottom. C. B. Miller says it is reminiscent of a crustacean spermatophore. D. Sample 502A-21-2, approx. 87 meters sub-bottom. J. $\mathrm{K}$. Thompson (personal communication) identified this as a chitonous mouth part of a crustacean, whereas C. B. Miller suggests it is a larval stage of an echinoderm. E. Sample 503B-25-2, approx. 106 meters sub-bottom. C. B. Miller identified this as a hook from a squid arm. 

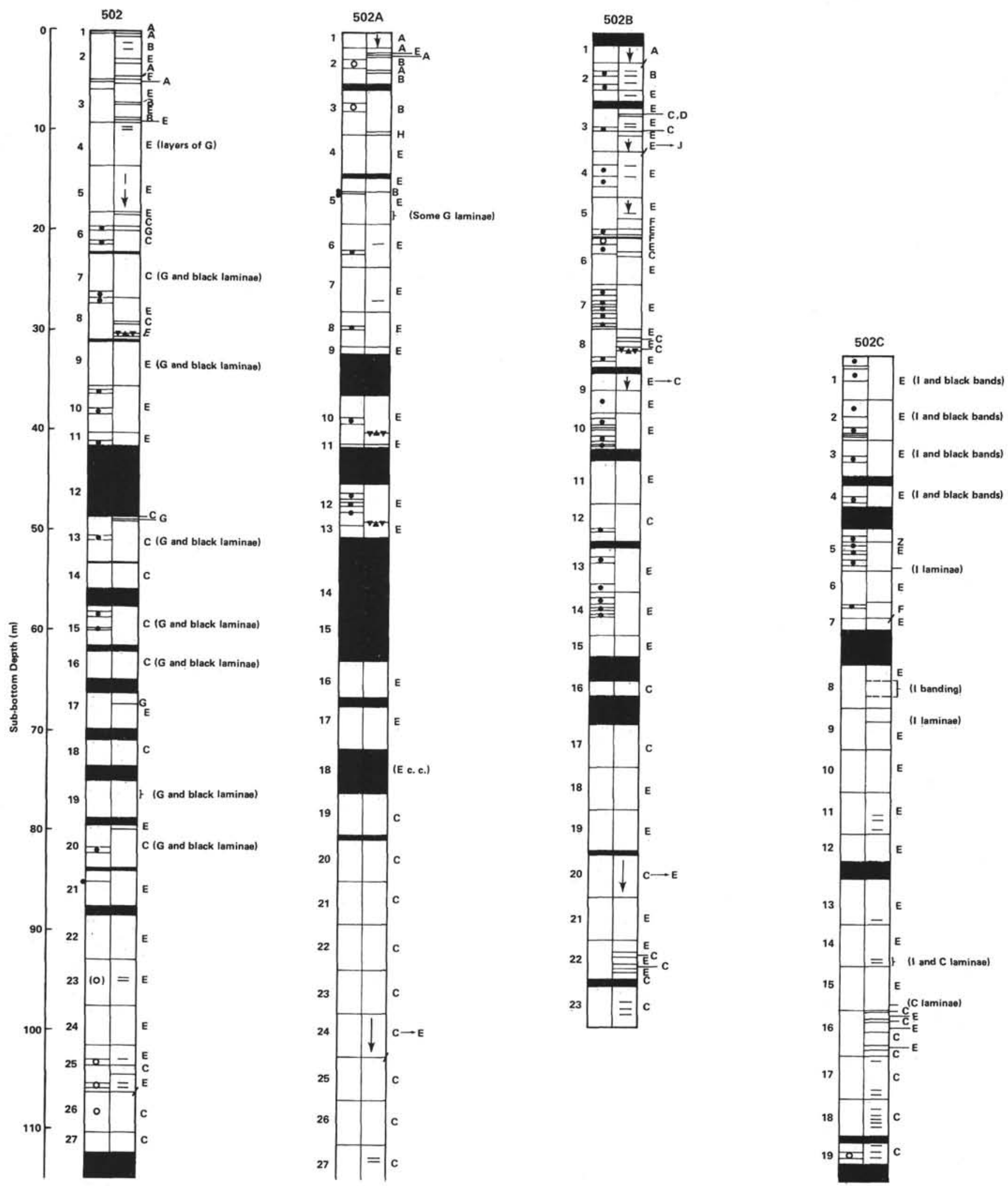

Figure 8. Log of textural and color variations versus sub-bottom depth in Holes 502, 502A, 502B, and 502C. 

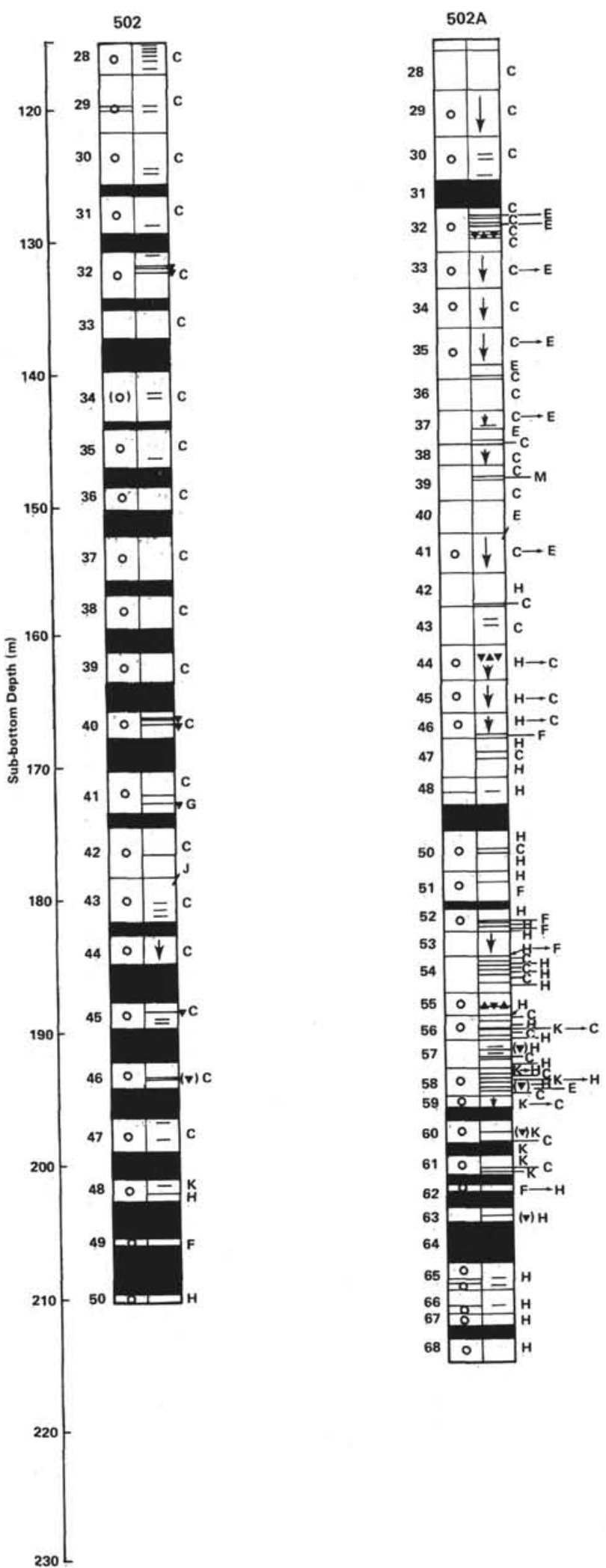

Figure 8. (Continued). 


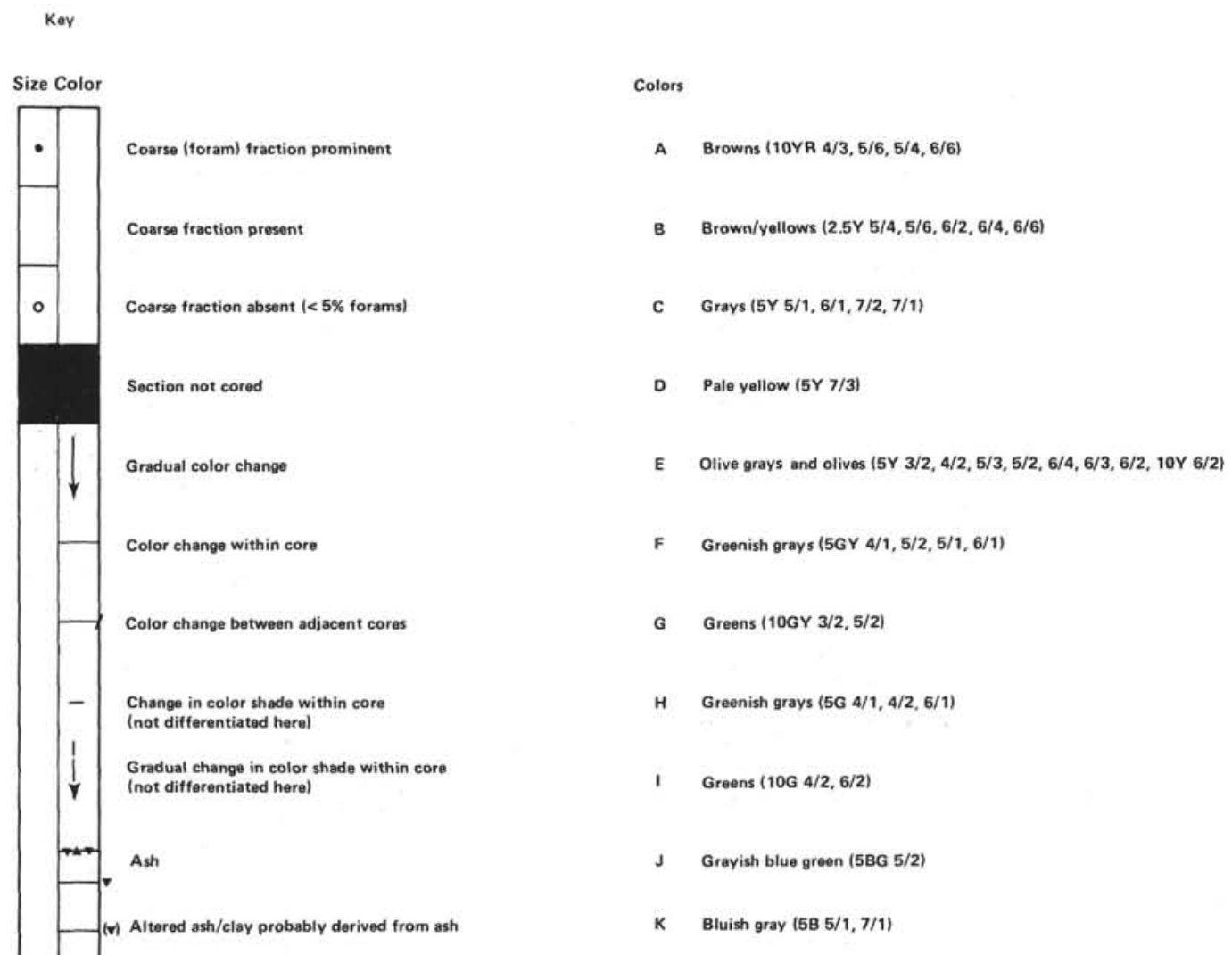

Figure 8. (Continued).

for samples from deeper than 100 meters sub-bottom are two to three times greater than any values previously determined on rotary-drilled material from an equivalent depth. Lee (1973) used the method of Ladd and Lambe (1963) to calculate in situ shear strength for a drilled section. The values from Site 502 closely resemble Lee's calculated in situ values rather than his raw data, implying that the HPC has caused minimal disturbance.

The needle penetrometer is a simple device that produced surprisingly consistent results. The data reveal a gradual decrease in penetration with increasing depth (Fig. 11) that can be attributed to compaction, but some of the secondary structure is probably due to lithologic variations. The large number of measurements provide an interesting insight into the nature of HPC disturbance. The penetration values for the upper 100 meters of the sediment show an imbricate structure; the top of each core gives anomalously high penetration that suggests disturbance in the upper part of each core. This pattern occurs despite the attempt to avoid obviously disturbed intervals. High penetration values in the uppermost section of each core become infrequent below about 100 meters, where increased induration minimizes disturbance.

$P$-wave velocities (Fig. 12) were measured both through the liner and on chunk samples used for gravimetric analyses. Surprisingly, the two values correlate reasonably well, probably because the cores completely filled the liner. Velocities range between 1.520 and 1.665 $\mathrm{km} / \mathrm{s}$. A cyclic variation in velocity can be seen in the top 70 to 80 meters of the sediment column. These cycles continue across core boundaries and are probably real. The velocity values are fairly constant from about 80 to 130 meters sub-bottom, with a baseline value of about $1.550 \mathrm{~km} / \mathrm{s}$, but the baseline shifts at 130 meters to about $1.580 \mathrm{~km} / \mathrm{s}$. We attempted to determine velocities on several ash layers but found it difficult to transmit sound through them. Successful measurements on an ash from about 173 meters sub-bottom reveals a maximum velocity of $1.81 \mathrm{~km} / \mathrm{s}$.

We collected density data on both continuous GRAPE and chunk samples (see Introduction). Saturated bulk density values vary from a minimum of about $1.44 \mathrm{~g} /$ $\mathrm{cm}^{3}$ at 4 meters to a maximum of $1.75 \mathrm{~g} / \mathrm{cm}^{3}$ at 198.3 meters sub-bottom (Fig. 13). Density increases with depth, but with numerous high-frequency fluctuations. Water content (Fig. 14) and porosity show the same trends, but with a sign opposite from that of saturated bulk density. A decrease in water content (increase in density and decrease in porosity) occurs at about 85 meters, coincident with an increase in shear strength. Unexpectedly high (about 50\%) water contents and low saturated bulk densities (about $1.50 \mathrm{~g} / \mathrm{cm}^{3}$ ) were measured on several of the ashes.

An interesting change in density, water content, and porosity occurs below 200 meters sub-bottom. Density significantly decreases below this level, but water content and porosity increase. Despite 200 meters of overburden, the material below this level has the lowest saturated bulk density of any material from the site (Mayer, 


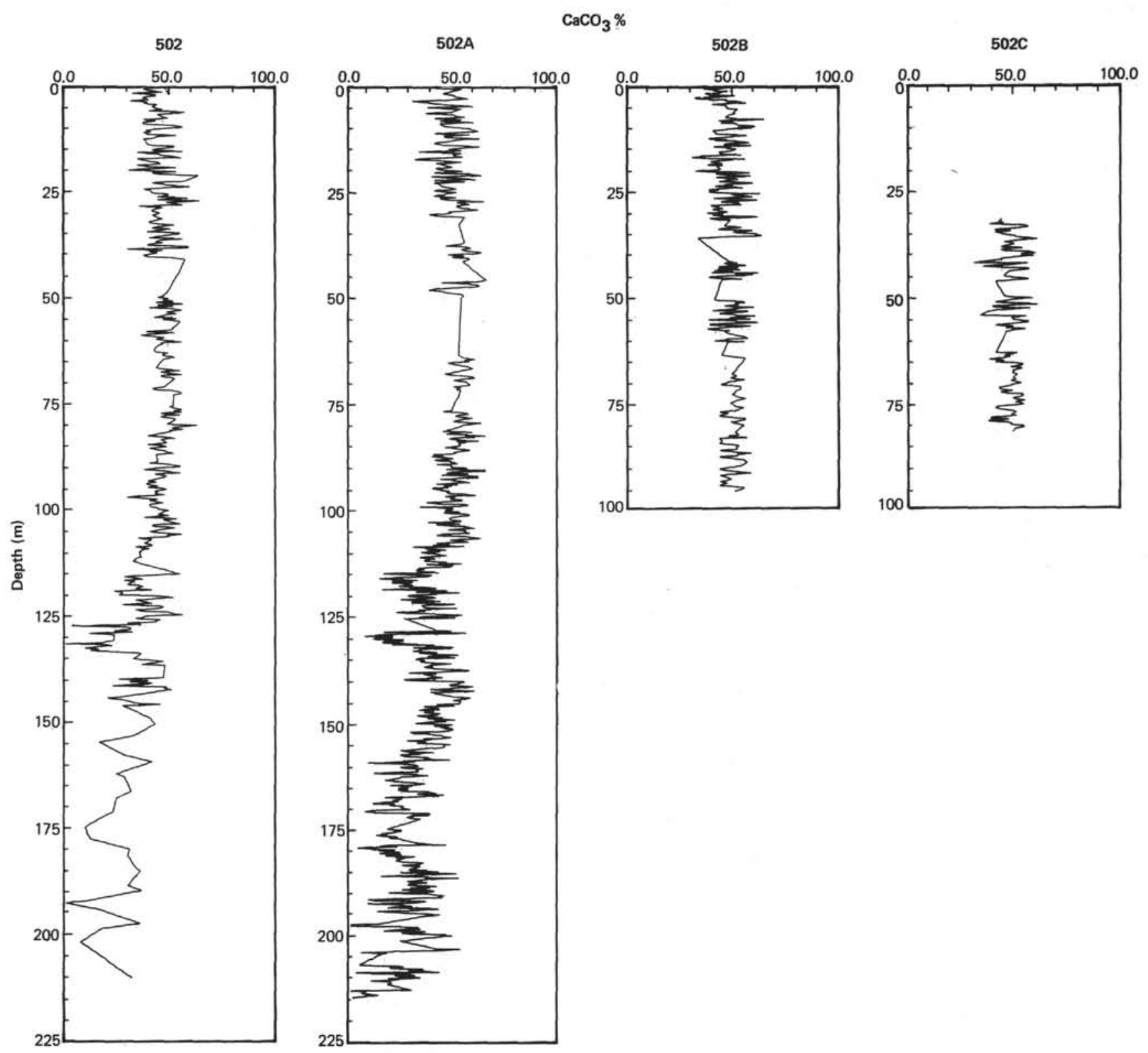

Figure 9. Calcium carbonate content versus sub-bottom depth for Holes 502, 502A, 502B, and 502C. (From Gardner, this volume.)

this volume). This change appears to be related to changes in the crystallinity of clay minerals, nannofossil preservation, and occurrence of siliceous microfossils.

\section{CORRELATION OF THE SEISMIC PROFILE AND CORED SECTION}

We approached Site 502 with a 40 - and a 5 -in. ${ }^{3}$ airgun array firing at 10 -s intervals. A slave recorder was delayed $5 \mathrm{~s}$ and filtered at $80 / 640 \mathrm{~Hz}$. Figure 4 is an enlargement of the slave record of Site 502. Sediment thicknesses were calculated using a velocity of $1550 \mathrm{~m} / \mathrm{s}$ (see Physical Properties section).

Three acoustic units were recognized in the upper 250 meters: (1) an upper acoustically stratified layer, 0 to 85 meters sub-bottom; (2) an acoustically transparent section, 85 to 200 meters sub-bottom; and (3) a faintly stratified layer, below 200 meters sub-bottom. Figure 15 shows a correlation between the seismic section converted to depth and the recovered section. Measured $P$-wave velocities on bulk samples and cores show larger variations of velocity in the 0 to 85 meter interval than below. The range varies from a minimum of 1.520 to a maximum of $1.665 \mathrm{~km} / \mathrm{s}$. The velocity of the section below 85 meters averages $1.550 \mathrm{~km} / \mathrm{s}$, with less variation about the mean. This might explain why the acoustic section above 85 meters is acoustically stratified and the section below this level is acoustically transparent.

We found a rough agreement between the acoustic units and the lithologic units, but a better correlation exists with the profile of shear strength. Shear strength increases linearly from 30 to about $400 \mathrm{~g} / \mathrm{cm}^{2}$ between 0 and 120 meter sub-bottom but shows an increase to greater than $1000 \mathrm{~g} / \mathrm{cm}^{2}$ at about 85 meters. Water content decreases linearly in the top 100 meters from 50 to 


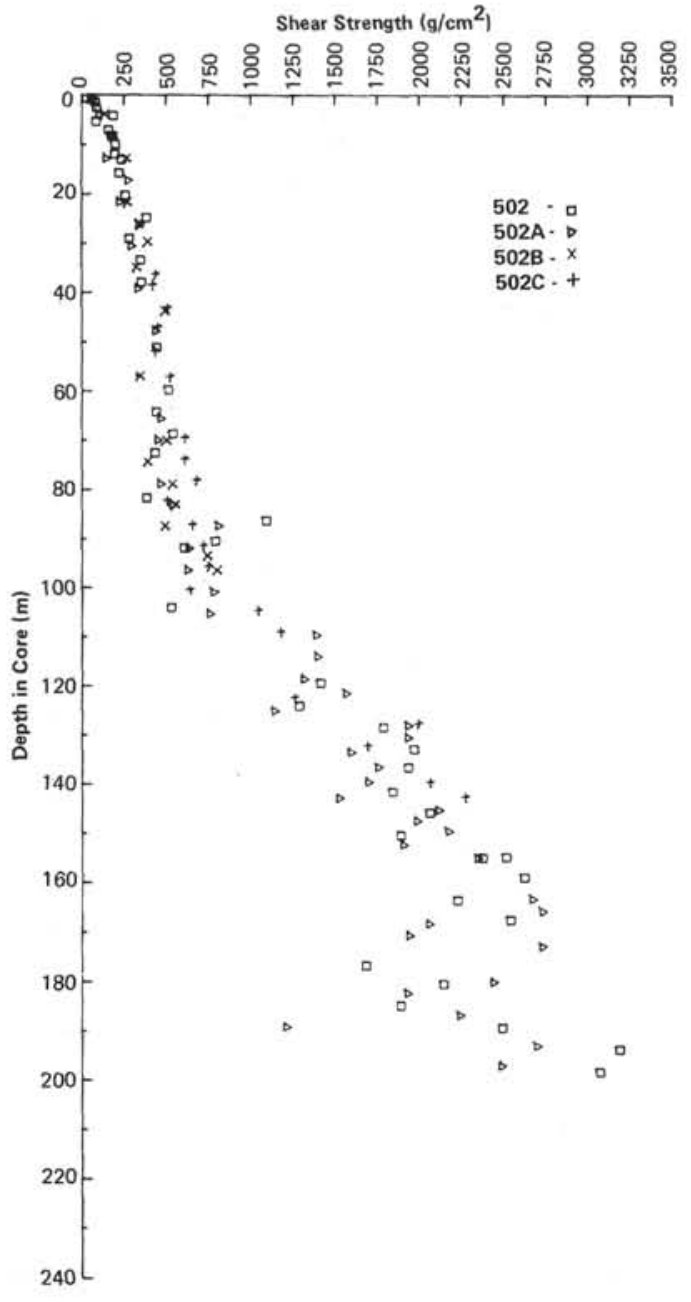

Figure 10. Shear strength $\left(\mathrm{g} / \mathrm{cm}^{2}\right)$, versus sub-bottom depth for Site 502.

$45 \%$, but at 85 meters the baseline shifts to about $40 \%$. The bulk density baseline also shifts from $1.5 \mathrm{~g} / \mathrm{cm}^{3}$ above 85 meters to $1.6 \mathrm{~g} / \mathrm{cm}^{3}$ below 85 meters. This level is coincident with the contact between Acoustic Units 1 and 2, and this correlation is similar to that found by Mayer (1979).

\section{BIOSTRATIGRAPHY}

Foraminifers, calcareous nannofossils, radiolarians, and diatoms were found at Site 502. Foraminifers and nannofossils are present throughout, but siliceous microfossils are found only at the top and near the base of the section. Good preservation and high abundances of calcareous microfossils characterize the Quaternary and upper Pliocene section. A decrease in preservation and abundances occurs below approximately 110 meters subbottom. This decrease is coupled with the presence of a cold-water(?) planktonic foraminiferal species (sinistral Neogloboquadrina pachyderma) associated with an otherwise tropical-subtropical fauna and the absence of uniquely tropical nannofossils. Preservation of calcareous microfossils is poor to moderate in upper Miocene sediment, and abundance decreases near the base of the section, where siliceous microfossils occur. A detailed discussion of the stratigraphic relationships among for-

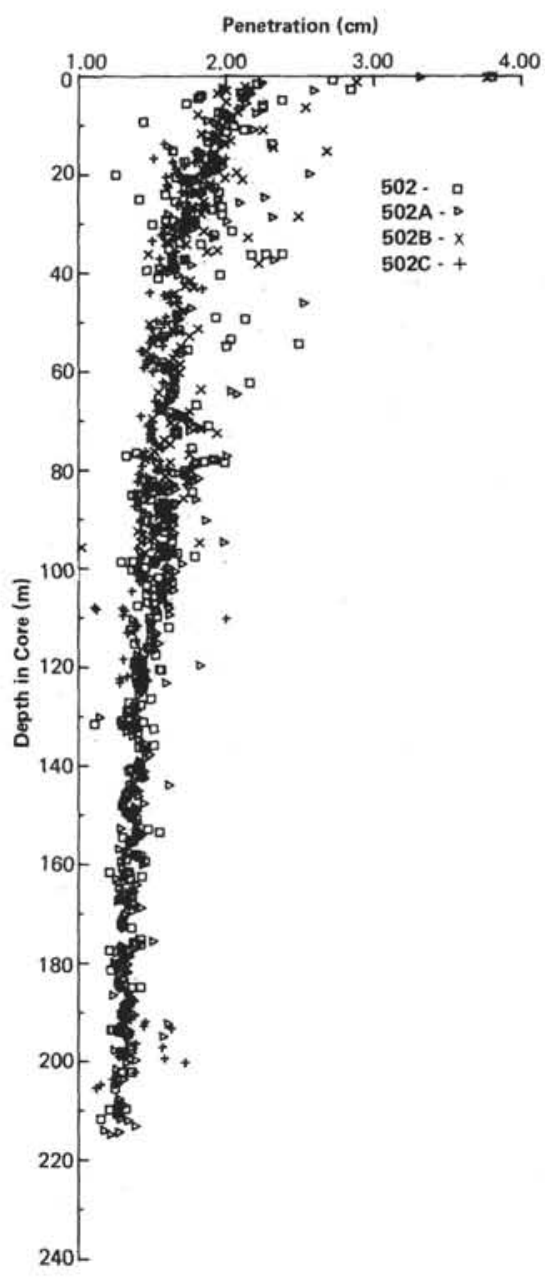

Figure 11. Penetrometer penetration $(\mathrm{cm})$ versus sub-bottom depth for Site 502.

aminifers, calcareous nannofossils, radiolarians, and diatoms is found in Kent and Keigwin (this volume).*

We identified most major epoch boundaries by foraminiferal horizons. However, we use the last appearance of Discoaster brouweri to define the Pliocene-Pleistocene boundary. Biostratigraphic resolution is poor in the mid-Pliocene for both nannofossils and foraminifers. The informal boundary between lower and upper Pliocene was chosen as the last appearance of Sphaeroidinellopsis $\mathrm{sp}$. at approximately 81 meters.

The Miocene/Pliocene boundary was identified at about 146 meters sub-bottom on the basis of the first appearance of Globorotalia tumida. This boundary is not precisely determined by calcareous nannofossil zones, but the lowest occurrence of Ceratolithus acutus at 141 meters correlates well with the foraminiferal boundary. The upper Miocene sequence has poor stratigraphic resolution. Calcareous microfossils are rare and poorly preserved, so that only one foraminiferal zone and three calcareous nannofossil zones can be identified in this interval. The base of the section is early-late Miocene in age. Radiolarians characteristic of the Didymocyrtis antepenultima Zone are found below 211 meters. Diatom biohorizons suggest that this interval may be correlative

- This chapter does not appear in this volume. 


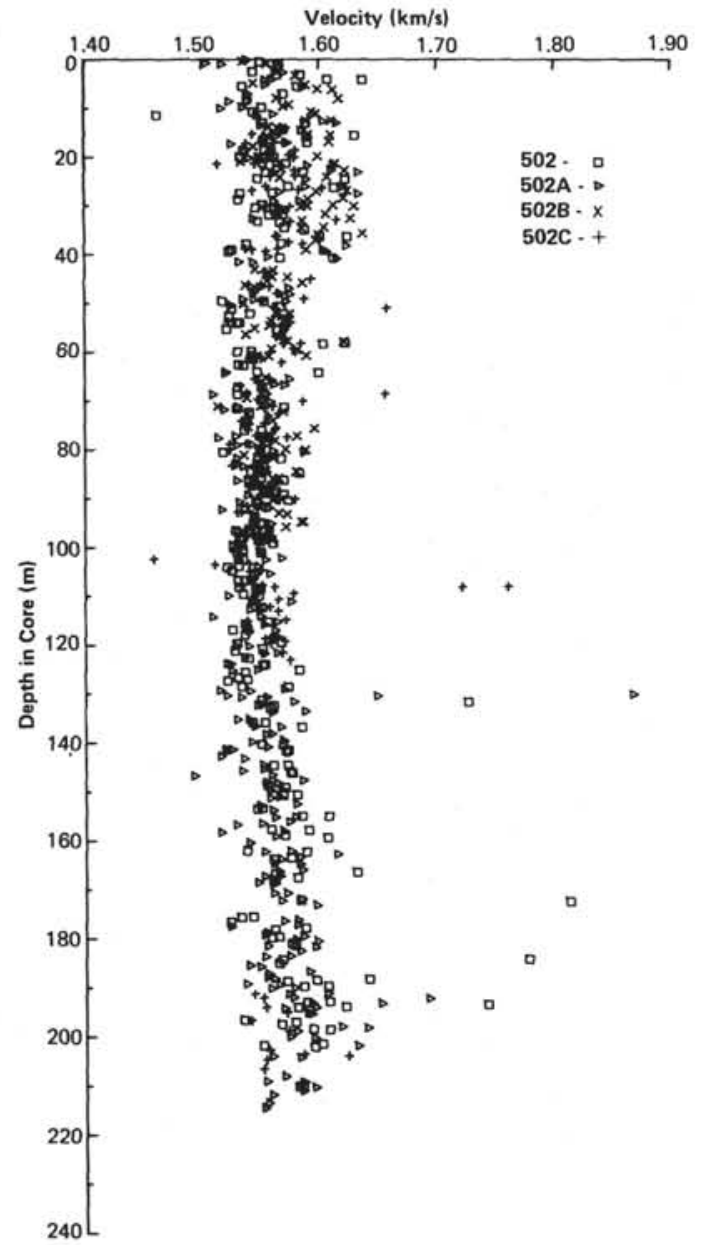

Figure 12. Sonic velocity $(\mathrm{km} / \mathrm{s})$ versus sub-bottom depth for Site 502 .

with paleomagnetic Chrons 7 and 8 , ranging from 7.5 to 8.5 Ma.

Figure 16 includes the major biostratigraphic zonations identified at Site 502. The details of each biotic group are given in the following.

\section{Calcareous Nannofossils}

Calcareous nannofossils occur throughout the sediments of Site 502. Preservation of calcareous nannofossils is generally good, but the abundance and preservation slightly decrease below 115 meters sub-bottom (mid-Pliocene). However, nannofossils continue to be common to abundant with good to moderate preservation down to approximately 214 meters, where another drop in abundance, but not preservation, occurs. The nannofloral assemblage from Quaternary to the midPliocene is characterized by an abundance of warm water taxa, such as Scyphosphaera and discolithinids, as well as abundant and diverse discoasters in the upper Pliocene. These diagnostic taxa are absent or less abundant below the mid-Pliocene. A complete sequence of all Quaternary, Pliocene, and upper Miocene nannofossil zones was recovered and is described in part by Rio (this volume). Here, we summarize the shipboard nannofloral biostratigraphy, with emphasis on the zonal and epoch boundaries (Figs. 16 and 19).

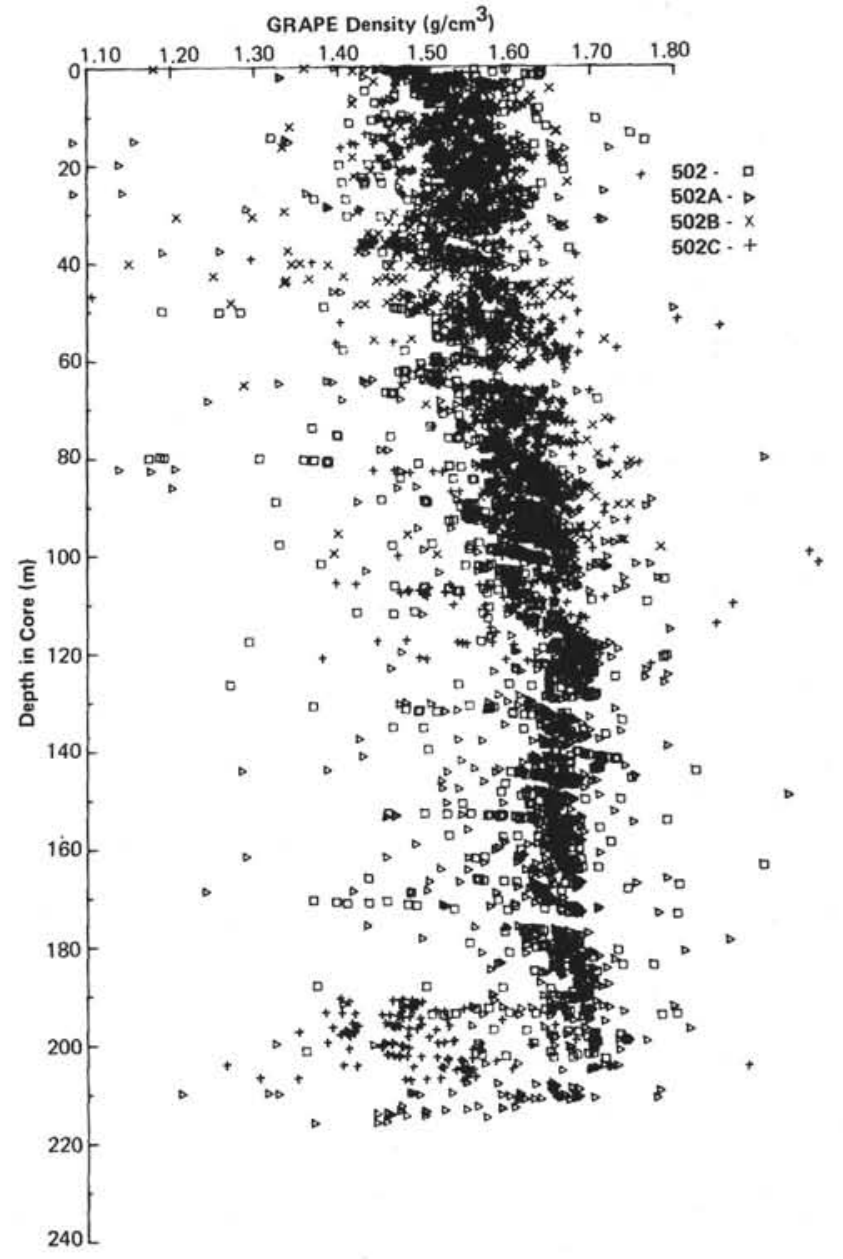

Figure 13. Saturated bulk density $\left(\mathrm{g} / \mathrm{cm}^{3}\right)$ versus sub-bottom depth for Site 502.

Nannofloral assemblages are diverse and well preserved throughout the Quaternary sequence, and all zones except the Emiliania huxleyi Acme Zone (Holocene) of Gartner (1977) are present at this site. Pseudoumbilica lacunosa is relatively rare in the upper part of its range but becomes dominant in the early Pleistocene assemblages. The short range of the small Gephyrocapsa is distinctive in this interval, in which larger forms of this genus are quite sparse. The highest occurrence of Cyclococcolithus macintyrei was consistently found above the last occurrence of discoasters.

The Pliocene/Pleistocene boundary can be defined at this site by the last occurrence of Discoaster brouweri, which occurs in Sections 502A-12-2, $71 \mathrm{~cm}$; 502B-11-1, $101 \mathrm{~cm}$; and $502 \mathrm{C}-2-2,31 \mathrm{~cm}$, between 48 and $38 \mathrm{me}-$ ters, respectively (Burnett and Prell, this volume*). Rio (this volume) uses the appearance of Gephyrocapsa oceanica to define the Pliocene/Pleistocene boundary. The completeness of the recovered sections allows the differentiation of all short upper Pliocene nannofossil zones that are based on discoaster succession. Biostratigraphic resolution in the mid- and lower Pliocene is somewhat poorer than in the upper Pliocene. The last occurrence

- This chapter does not appear in this volume. 


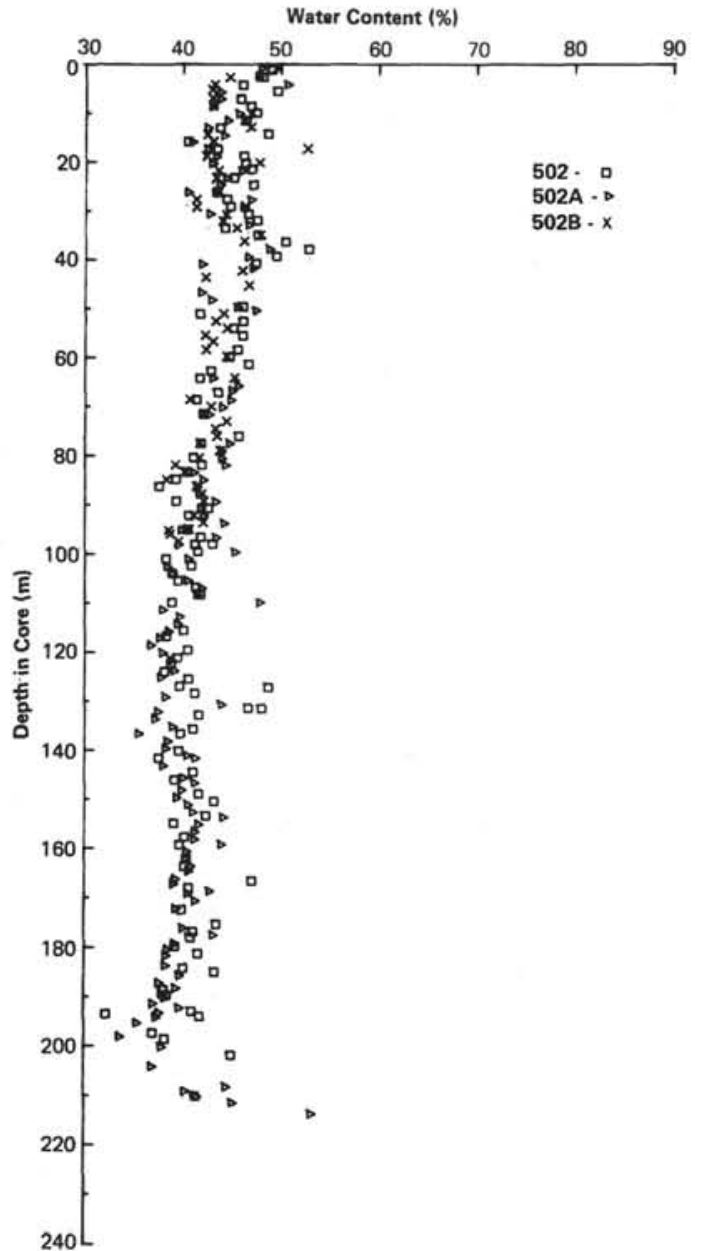

Figure 14. Water content versus sub-bottom depth for Site 502 .

of D. tamalis (between Sections 502-17,CC and 502$18, \mathrm{CC}, 502 \mathrm{~A}-16, \mathrm{CC}$ and 502A-17, CC, 502B-16,CC and 502B-17, CC, and 502C-8, CC and 502C-9, CC) provides a reliable datum to differentiate upper from lower Pliocene. However, D. tamalis is fairly sparse in this section, particularly near the top and bottom of its range.

The lower Pliocene is subdivided using primarily ceratoliths, which are generally rare in this section. The last occurrence of Amaurolithus tricorniculatus is somewhat difficult to determine because of its sparsity. $\mathrm{Ce}$ ratolithus rugosus is rare at the base of its range, so we used the highest occurrence of $C$. acutus (Samples 502$31-1,75 \mathrm{~cm}$ to $502-31-2,75 \mathrm{~cm} ; 502 \mathrm{~A}-31, \mathrm{CC}$ to $502 \mathrm{~A}$ $32, \mathrm{CC}$; and $502 \mathrm{C}-21, \mathrm{CC}$ to $502 \mathrm{C}-22, \mathrm{CC}$ ) at nearly the same level or slightly lower in this section to define the base of the $C$. rugosus Zone. A. primus provides a reliable datum, with its uppermost occurrence just above the Miocene/Pliocene boundary. The base of C. acutus was consistently above the Miocene/Pliocene boundary (as defined by foraminiferal evidence) at approximately 140 meters depth. This boundary occurs within the lowermost Pliocene nannofossil zone in most standard calcareous nannofossil zonations. We used the base of $C$. acutus (Samples 502-34-1, $75 \mathrm{~cm}$ to $502-34-2,75 \mathrm{~cm}$; $502 \mathrm{~A}-35, \mathrm{CC}$ to $502 \mathrm{~A}-36, \mathrm{CC}$; and $502 \mathrm{C}-25, \mathrm{CC}$ to $502 \mathrm{C}-$ $26, \mathrm{CC}$ ) to approximate the Miocene/Pliocene boundary.
Two subzones of the $D$. quinqueramus Zone of the uppermost Miocene are recognized at this site. The $A$. primus subzone extends through most of the $D$. quinqueramus Zone, with the $D$. berggreni Subzone in the lowermost part (Fig. 15). D. quinqueramus, D. berggreni, D. surculus, D. pentaradiatus, and Reticulofenestra pseudoumbilica are common throughout the A. primus Subzone, whereas A. primus is relatively sparse. The first occurrence of $R$. pseudoumbilica occurs near the base of this subzone. The base of the $D$. quinqueramus Zone was encountered at about 214 meters subbottom. The nannofloral assemblage occurring at the base of the section is characteristic of the lowermost upper Miocene and includes $D$. bellus, D. variabilis, and D. neohamatus.

\section{Planktonic Foraminifers}

Planktonic foraminifers occur throughout Site 502 but are most abundant in the Quaternary and upper Pliocene. The lower part of upper Miocene sediments is characterized by intervals of carbonate dissolution and consequently rare foraminifers. A complete discussion of the biostratigraphy, including the sample location of foraminiferal datums and zonal boundaries and biogeography of the Neogene planktonic foraminifers, is given in Keigwin (this volume). Here, we summarize their biostratigraphy, with emphasis on the epoch and zonal boundaries.

We generally follow the biostratigraphic framework developed by Jenkins and Orr (1972) because it is applicable to both the Atlantic and Pacific faunas. The planktonic foraminiferal zonation is summarized in Figures 16 and 19. The Pliocene/Pleistocene boundary as defined by the first appearance of Globorotalia truncatulinoides occurs in Samples 502A-12-3, $59 \mathrm{~cm}, 502 \mathrm{~B}-$ $11-2,111 \mathrm{~cm}$, and 502C-2-3, $41 \mathrm{~cm}$ (Burnett and Prell, this volume) near the last appearance of Discoaster brouweri at about 45 meters sub-bottom. The lower/upper Pliocene boundary is informally defined by the last appearance of Sphaeroidinellopsis sp., which occurs in Samples 502-20-1, $100 \mathrm{~cm}, 502 \mathrm{~A}-20-2,50 \mathrm{~cm}, 502 \mathrm{~B}-19-$ $2,75 \mathrm{~cm}$, and $502 \mathrm{C}-10-3,70 \mathrm{~cm}$. The Miocene-Pliocene boundary is defined by the first appearance of $G$. $t u$ mida in Sample 502-35,CC, 502A-37,CC, and 502C$26, \mathrm{CC}$. The upper Miocene has proven impossible to zone. Either important marker species are absent (such as the first appearance of Pulleniatina sp.) or they are difficult to identify with certitude (such as the first appearance of $G$. plesiotumida).

An interesting faunal change appears in the mid Pliocene. Sediment from DSDP Hole 154A in the Colombia Basin contains abundant sinistral Neogloboquadrina pachyderma within a predominantly tropical assemblage in an interval dated at about 3.6-3.7 Ma (Keigwin, 1978). This association is surprising because sinistral $N$. pachyderma is thought to the "coldest" phenotype of the "coldest" foraminifer species in Holocene distributions. This interval marks the bottom of the hemipelagic section of Hole 154A. Sediment at Site 502 is hemipelagic throughout, and this same assemblage is present in Cores 502-28 to 502-48. Thus the interval of sinistral $N$. 


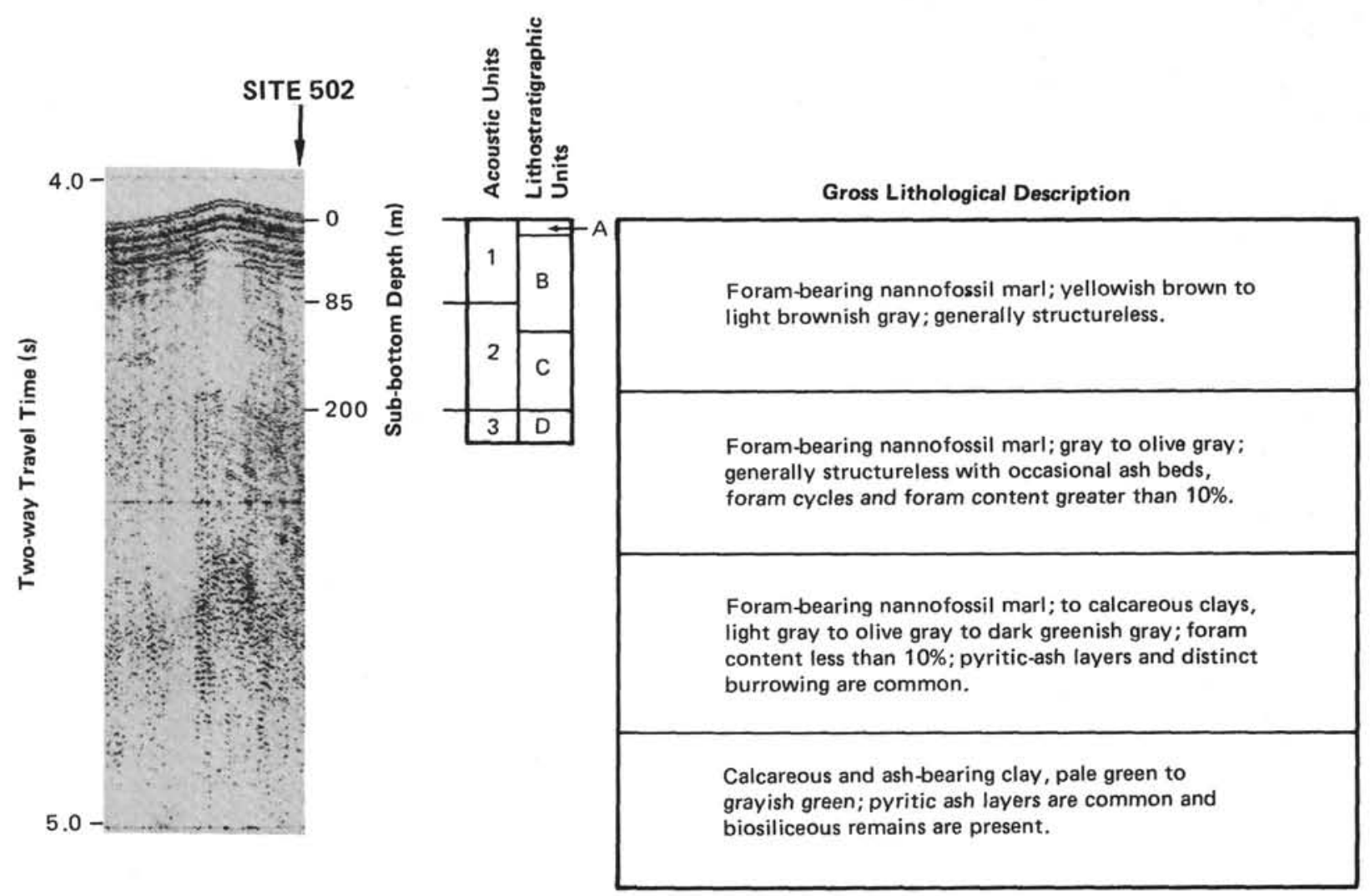

Figure 15. Correlation between the acoustic units recognized on the airgun seismic profile (filtered at $80 / 640 \mathrm{~Hz}$ ) and the lithostratigraphic units at Site 502 .

pachyderma occurrence is not short as assumed at Hole $154 \mathrm{~A}$ but represents a fauna that spans about 1.5 m.y.

\section{Diatoms}

Diatoms are absent throughout most of the section. Scattered fragments occur only in the lowermost cores from Hole 502C. Diatoms are common and fairly well preserved in one sample, $502 \mathrm{C}-30-1,18 \mathrm{~cm}$. In addition to various long-ranging species, Nitzschia porteri and Thalassiosira burkliana are present. If the age ranges for these species are the same as in the Pacific, then the age of this sample is mid-late Miocene (7.5-8.5 m.y.)within the $N$. porteri Zone of Burckle (1972) (Fig. 16).

\section{Radiolarians}

Radiolarians and indeed siliceous microfossils in general are not present in Tertiary sediments younger than about middle Miocene in the Gulf of Mexico and Caribbean (Riedel and Sanfilippo, 1973; Sanfilippo and Riedel, 1973, 1976). Cores from Site 502 were examined for radiolarians to establish whether this absence is continuous from mid-Miocene onward and to attempt to shed light on the reason for their absence. A channel sample of about 5 to $10 \mathrm{cc}$ total volume was taken throughout the length of each core section from Hole 502A, disaggregated, sieved through a $63-\mu \mathrm{m}$ mesh, and the coarse fraction acidified to remove the calcareous microfossils.

Siliceous radiolarian skeletons were found only in Cores 502A-1 and 502B-1 (increasingly corroded downward), of Quaternary age, and in 502A-67 and 502A-68 (less corroded downward), of early late Miocene age (Didymocyrtis antepenultima Zone) (see Figs. 16 and 19). Many samples between these two radiolarian intervals (notably from Cores 502A-50 and 51 and above) contain very rare, fragmentary radiolarians and sponge spicules replaced by an opaque mineral.

A few moderately well-preserved radiolarians occur in Cores 502-28 and 29. The abundance and state of preservation of radiolarians below 215 meters sub-bottom decline to a minimum in Core 502C-35. Preservation improves within a pyritized mass in Core 502-36, but radiolarians remain very rare as a result of dilution with volcanogenic components. The assemblage in Core $502 \mathrm{C}-36$ represents the $D$. antepenultima Zone, but it is possible that the lump was displaced from higher in the hole and that the sediment at this depth is somewhat older. The worsening preservation in Samples 502C$30, \mathrm{CC}$ to $502 \mathrm{C}-35, \mathrm{CC}$ indicates that the transition from radiolarian-rich sediment of the middle Tertiary to radiolarian-absent sediment in the upper Tertiary section is irregular.

The well-preserved radiolarians at the top and bottom of the section represent diverse assemblages characteristic of tropical, open ocean conditions, and, as far as can be determined, the opaque fragments are the remnants of a normal oceanic assemblage (with orospaerids, Lamprocyclas, etc.). The evidence suggests that the absence of siliceous microfossils in sediments of this region is continuous from the early late Miocene to the Quaternary and that dissolution within the sediment, 


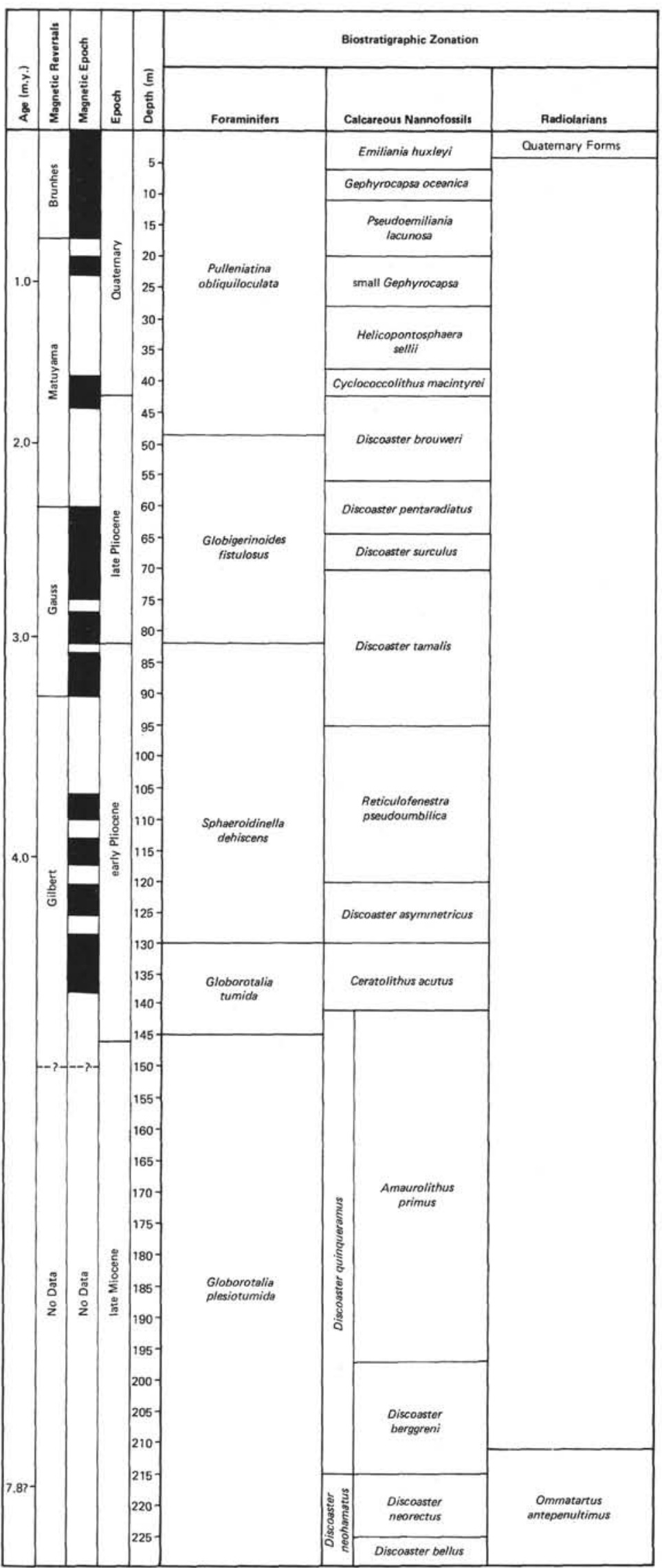

Figure 16. Summary of the biostratigraphic zonations of Site 502. 
rather than absence from the waters above, was responsible.

\section{PALEOMAGNETISM}

The undisturbed nature of the HPC sediment allowed us to perform detailed paleomagnetic measurements on the section. Paleomagnetic measurements, using a longcore spinner magnetometer, were made at $15-\mathrm{cm}$ intervals in Hole 502 and at $10-\mathrm{cm}$ intervals in Holes 502A, $502 \mathrm{~B}$, and $502 \mathrm{C}$. The long-core spinner magnetometer gives the direction of the declination component of natural remanent magnetization (NRM) of the sediment with respect to an orientation mark on the core liner. Unfortunately, the sense of the orientation mark was not always maintained from core to core, so the polarity of sediment magnetization (normal or reversed) was sometimes ambiguous. Additional information was obtained from measurement of individual sample cubes taken after the cores were split. Polarity could be established in most cases from the sign of the vertical component of the NRM. This information was used to interpret the polarity of intervals that have a similar declination within the rest of each core. An additional declination adjustment was applied to each core to align the determined polarities from core to core.

A magnetic polarity log was developed for each hole (Fig. 17; Table 4). No-recovery intervals and various degrees of core disturbance required the construction of a composite section by overlapping the best records from each hole. We can identify the following composite magnetozones: Brunhes, 0 to 17 meters; Matuyama, 17 to 60 meters; Gauss, 60 to 89 meters; Gilbert, 89 to at least 142 meters (Fig. 17; Table 4). The paleomagnetic polarity record below about 140 meters is complicated by a marked shallowing of the inclinations, combined with an increase in unstable magnetization.
We also identify all the recognized magnetosubchrons within the Matuyama (Jaramillo and Olduvai), Gauss (Kaena and Mammoth), and Gilbert (Cochiti, Nunivak, $\mathrm{C}_{1}$, and $\mathrm{C}_{2}$ ) Chrons. Additional short-term paleomagnetic features not universally recognized are tentatively identified within the Matuyama Chron. One of these may correlate to the Cobb Mt. Subchron and another to the Reunion Subchron. Correlation to the magnetic reversal time scale shows we recovered a virtually complete stratigraphic sequence for at least the past $4.5 \mathrm{~m} . \mathrm{y}$. A detailed discussion of the magnetostratigraphy for Site 502 is presented by Kent and Spariosu (this volume).

\section{ACCUMULATION RATES}

We used 12 horizons to generate sedimentation rate and accumulation rate curves for Site 502. These horizons represent the nine best magnetostratigraphic boundaries, the base of the Amaurolithus primus and Discoaster neorectus zones, and an assumed zero age for the sediment/water interface. The age and thickness of the 11 time intervals are given in Table 5. The thickness of each interval was computed in holes that contain both age boundaries so that differences in sub-bottom depth between holes are eliminated. Exceptions to this practice are Interval 9, from the top of Gilbert $C_{1}$ to the bottom of Gilbert $\mathrm{C}_{2}$ Subchrons, and Interval 11, bounded by the biostratigraphic datums not recovered in one hole.

A sedimentation rate for each time interval was calculated from the age versus depth. Because sedimentation rate is a function of both sediment influx at the time of deposition and postdepositional compaction, bulk accumulation rates were calculated in order to remove some of the compaction effect. The calculated accumulation rate provides a better approximation of sediment influx rate, particularly in older compacted sediment (van Andel et al., 1975). Sedimentation rates at

Table 4. Location in each hole and the sub-bottom depths of the paleomagnetic boundaries found at Site 502.

\begin{tabular}{|c|c|c|c|c|c|c|c|c|}
\hline \multirow[b]{2}{*}{$\begin{array}{l}\text { Paleomagnetic Chrons } \\
\text { and Subchrons }\end{array}$} & \multicolumn{2}{|c|}{ Hole 502} & \multicolumn{2}{|c|}{ Hole $502 \mathrm{~A}$} & \multicolumn{2}{|c|}{ Hole 502B } & \multicolumn{2}{|c|}{ Hole $502 \mathrm{C}$} \\
\hline & $\begin{array}{c}\text { Sample } \\
\text { (interval in } \mathrm{cm} \text { ) }\end{array}$ & $\begin{array}{l}\text { Sub-bottom } \\
\text { Depth (m) }\end{array}$ & $\begin{array}{c}\text { Sample } \\
\text { (interval in } \mathrm{cm} \text { ) }\end{array}$ & $\begin{array}{l}\text { Sub-bottom } \\
\text { Depth (m) }\end{array}$ & $\begin{array}{c}\text { Sample } \\
\text { (interval in } \mathrm{cm} \text { ) }\end{array}$ & $\begin{array}{l}\text { Sub-bottom } \\
\text { Depth (m) }\end{array}$ & $\begin{array}{c}\text { Sample } \\
\text { (interval in } \mathrm{cm} \text { ) }\end{array}$ & $\begin{array}{l}\text { Sub-bottom } \\
\text { Depth (m) }\end{array}$ \\
\hline Brunhes/Matuyama & - & - & $5-2,60-70$ & $17.20 \pm 0.05$ & $5-1,140-150$ & $16.25 \pm 0.05$ & - & - \\
\hline top of Jaramillo & $6-1,110-145$ & $19.27 \pm 0.17$ & $6-1,80-90$ & $20.90 \pm 0.05$ & $5-3,110^{a}$ & 18.62 & - & - \\
\hline bottom of Jaramillo & $6-3,55-75$ & $21.66 \pm 0.10$ & $6-3,15-25$ & $22.28 \pm 0.05$ & $6-2,45-70$ & $21.44 \pm 0.13$ & - & - \\
\hline top of Olduvai & $10-2,120-135$ & $38.07 \pm 0.07$ & $10-2,105-115$ & $39.70 \pm 0.05$ & - & - & - & - \\
\hline bottom of Olduvai & - & - & $12-1,90-100$ & $46.75 \pm 0.05$ & $11-1,90-110$ & $42.30 \pm 0.07$ & - & - \\
\hline Matuyama/Gauss & $15-2,115-130$ & $60.21 \pm 0.05$ & - & - & - & - & $6-2,125-140$ & $55.47 \pm 0.07$ \\
\hline top of Kaena & - & - & $19-1,140-145$ & $77.87 \pm 0.02$ & $\begin{array}{l}18-1,140 \\
18-2,15\end{array}$ & $73.36 \pm 0.13$ & $9-1,100-130$ & $68.30 \pm 0.10$ \\
\hline bottom of Kaena & - & - & $19-3,20-50$ & $79.80 \pm 0.15$ & $18-3,40-50$ & $75.59 \pm 0.05$ & $\begin{array}{l}9-2,145 \\
9-3,20\end{array}$ & $70.28 \pm 0.13$ \\
\hline top of Mammoth & $20-1,90-105$ & $80.54 \pm 0.07$ & $20-2,90-100$ & $83.42 \pm 0.05$ & $19-2,110-120$ & $79.20 \pm 0.05$ & $10-2,60-100$ & $73.72 \pm 0.05$ \\
\hline bottom of Mammoth & $\begin{array}{l}20-2,145 \\
20-3,17\end{array}$ & $82.62 \pm 0.11$ & - & - & - & - & - & - \\
\hline Gauss/Gilbert & $22-1,90-105$ & $89.37 \pm 0.07$ & $22-2,30-70$ & $91.91 \pm 0.20$ & - & - & - & - \\
\hline top of Cochiti & $25-3,75-80$ & $105.30 \pm 0.02$ & - & - & - & - & $\begin{array}{l}16-2,115 \\
16-3,20\end{array}$ & $101.07 \pm 0.13$ \\
\hline bottom of Cochiti & $26-3,15-30$ & $109.0 \pm 0.07$ & - & - & - & - & $17-2,120-135$ & $104.87 \pm 0.07$ \\
\hline top of Nunivak & - & - & $28-1,70-90$ & $116.94 \pm 0.10$ & - & - & $18-2,125-130$ & $109.51 \pm 0.03$ \\
\hline bottom of Nunivak & - & - & $29-1,100-120$ & $120.40 \pm 0.10$ & - & - & $19-1,130-145$ & $112.52 \pm 0.07$ \\
\hline top of $C_{1}$ & - & $\quad-$ & - & - & - & - & $20-2,70-90$ & $117.90 \pm 0.10$ \\
\hline bottom of $\mathrm{C}_{1}$ & $30-3,15-30$ & $124.91 \pm 0.07$ & - & - & - & - & $\begin{array}{l}21-1,100 \\
21-2,20\end{array}$ & $121.35 \pm 0.35$ \\
\hline top of $C_{2}$ & $31-2,45-60$ & $128.12 \pm 0.07$ & - & - & - & - & - & - \\
\hline bottom of $\mathrm{C}_{2}$ & - & - & $34-1,90-100$ & $135.25 \pm 0.05$ & - & - & - & - \\
\hline
\end{tabular}

a The paleomagnetic record was not definitive in this hole, so correlation with oxygen isotope stratigraphy (Prell, this volume) was also used to confirm the location of this datum. 


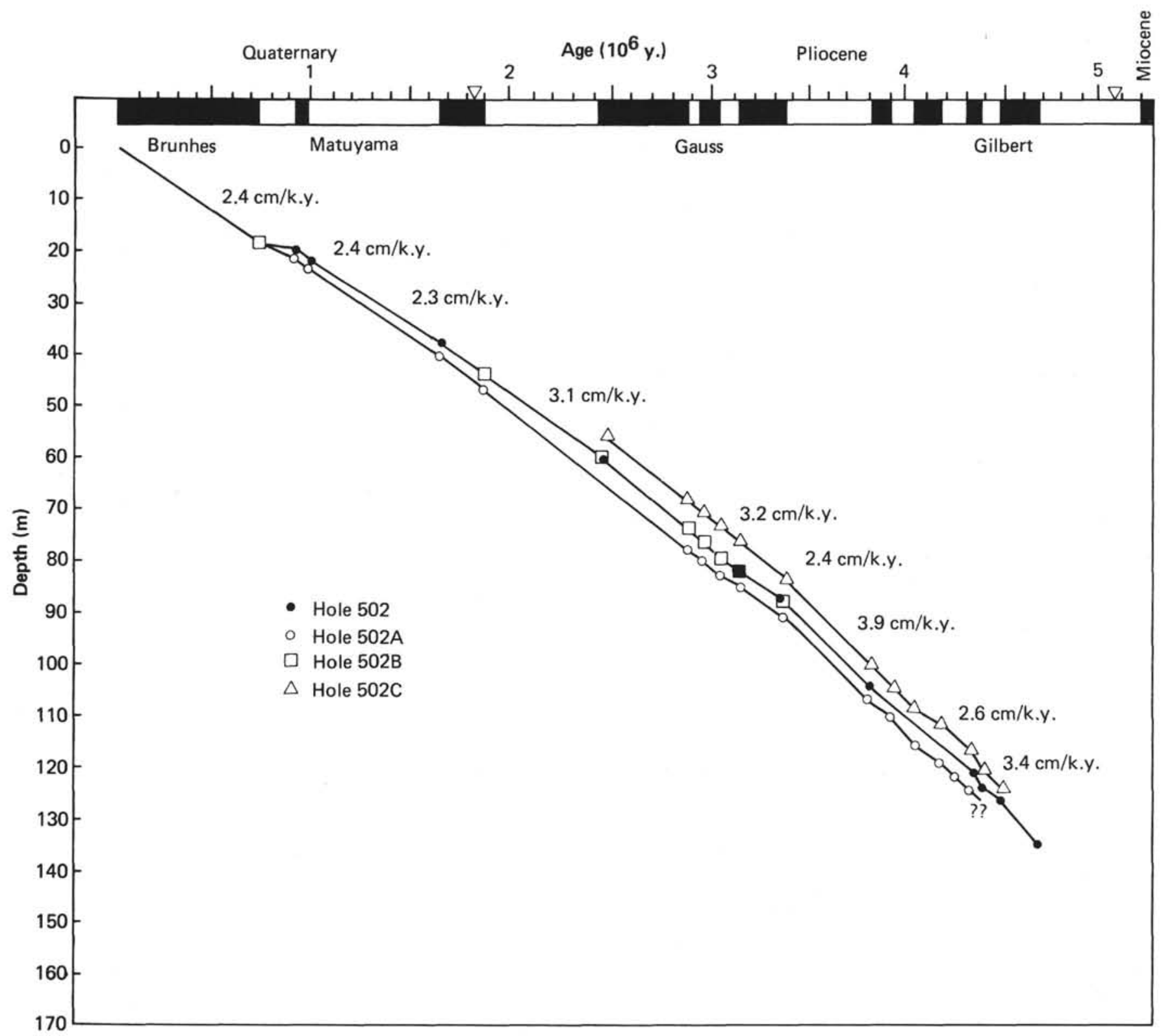

Figure 17. Age versus depth in hole for magnetostratigraphic boundaries in Site 502. Average sedimentation rates between selected magnetostratigraphic boundaries are also given.

Site 502 range from 1.8 to $4.8 \mathrm{~cm} / \mathrm{k} . \mathrm{y}$. with an average of $3.0 \mathrm{~cm} / \mathrm{k} . \mathrm{y}$. Highest sedimentation rates occur in the Pliocene to late Miocene, and lowest rates occur during the Pleistocene.

Wet-bulk density (GRAPE) and water content data were used to calculate bulk accumulation rates for each time interval used in the sedimentation rate curve (Table 5). Bulk accumulation rates (Fig. 18) show the same trend as sedimentation rate, with highest values for the intervals older than $1.8 \mathrm{~m}$.y. The apparent increase in the mid-Pliocene may be an artifact of the time scale. A major change in the time scale, however, would be required to change substantially the pattern of decreased rates throughout the section. The decrease in rates may be due to several factors, including sediment influx from terrigenous sources, biogenic productivity, and carbonate preservation. Carbonate and noncarbonate accumulation rates were calculated in order to separate some of these components.

Carbonate accumulation rates were calculated from bulk density and average carbonate content (Table 5). The trend in carbonate accumulation rates is quite different from bulk rates and varies by a factor of two in the section (Fig. 18). The Pliocene is characterized by higher carbonate accumulation rates than in the late Miocene and Pleistocene. The high rates persist over a period from approximately 2 to $5 \mathrm{Ma}$. The noncarbonate accumulation rate decreases from late Miocene to Holocene. The decrease in noncarbonate material must be due to a reduction in terrigenous sediment influx. 
Table 5. Measured and calculated parameters used to determine sedimentation and accumulation rates.

\begin{tabular}{|c|c|c|c|c|c|c|c|c|c|c|c|}
\hline \multirow[b]{2}{*}{ Time Interval } & \multirow[b]{2}{*}{$\begin{array}{c}\text { Age } \\
\text { (m.y.) }\end{array}$} & \multirow[b]{2}{*}{$\begin{array}{c}\text { Depth }^{\mathrm{a}} \\
\text { (m) }\end{array}$} & \multirow{2}{*}{$\begin{array}{l}\text { Mean } \\
\text { Thickness } \\
(\mathrm{m})\end{array}$} & \multirow[b]{2}{*}{$\begin{array}{l}\text { Sed. Rate } \\
(\mathrm{cm} / \mathrm{k} . \mathrm{y} .)\end{array}$} & \multirow[b]{2}{*}{$\underset{\mathrm{g} / \mathrm{cm}^{3}}{\operatorname{Mean} \delta_{y} \mathrm{c}}$} & \multirow[b]{2}{*}{$\begin{array}{l}\text { W.C. } \\
(\%)\end{array}$} & \multirow[b]{2}{*}{$\underset{\left(\mathrm{g} / \mathrm{cm}^{3}\right)}{\operatorname{Meen} \delta \mathrm{g}^{\mathrm{d}}}$} & \multirow[b]{2}{*}{$\begin{array}{c}\text { Bulk } \\
\text { Accum. Rate } \\
\left(\mathrm{g} / \mathrm{cm}^{2} / \mathrm{k} . \mathrm{y} .\right)\end{array}$} & \multirow{2}{*}{$\begin{array}{c}\text { Mean } \\
\mathrm{CaCO}_{3} \\
(\%)\end{array}$} & \multicolumn{2}{|c|}{ Accum. Rate ${ }^{f}$} \\
\hline & & & & & & & & & & $\underset{\left(\mathrm{g} / \mathrm{cm}^{2} / \mathrm{k} . \mathbf{y} .\right)}{\mathrm{CaCO}_{3}}$ & $\begin{array}{l}\text { Non- } \mathrm{CaCO}_{3} \\
\left(\mathrm{~g} / \mathrm{cm}^{2} / \mathrm{k} . \mathrm{y} .\right)\end{array}$ \\
\hline 0-Brunhes/Matuyama & $0-0.73$ & $\begin{array}{l}0-? \\
0-17.2 \\
0-16.2 \\
0-? \\
?-19.3\end{array}$ & 16.7 & 2.3 & $\begin{array}{l}1.6 \\
1.65\end{array}$ & $\begin{array}{l}46.5 \\
-\end{array}$ & 1.1 & 2.5 & $\begin{array}{l}47.1 \\
-\end{array}$ & 1.2 & 1.3 \\
\hline $\begin{array}{l}\text { Brunhes/Matuyama- } \\
\text { top of Jaramillo }\end{array}$ & $0.73-0.91$ & $\begin{array}{c}17.2-20.9 \\
16.2-21.4 \\
?\end{array}$ & 3.2 & 1.8 & $\begin{array}{l}1.6 \\
1.65 \\
-\end{array}$ & $\begin{array}{l}44.8 \\
-\end{array}$ & 1.1 & 1.9 & $\begin{array}{l}43.0 \\
=\end{array}$ & 0.8 & 1.1 \\
\hline $\begin{array}{l}\text { Top of Jaramillo- } \\
\text { top of Olduvai }\end{array}$ & $0.91-1.76$ & $\begin{array}{c}19.3-38.1 \\
20.9-39.7 \\
21.4-? \\
?\end{array}$ & 18.8 & 2.2 & $\begin{array}{l}1 . \overline{6} \\
1.6 \\
=\end{array}$ & $\begin{array}{l}48.4 \\
47.0 \\
- \\
=\end{array}$ & 1.1 & 2.4 & $\begin{array}{l}47.7 \\
49.6 \\
- \\
=\end{array}$ & 1.2 & 1.2 \\
\hline $\begin{array}{l}\text { Top of Olduvai- } \\
\text { Matuyama/Gauss }\end{array}$ & $1.76-2.48$ & $\begin{array}{c}38.1-60.2 \\
39.7-? \\
?\end{array}$ & 22.1 & 3.1 & $\begin{array}{l}1.6 \\
-\end{array}$ & $\begin{array}{l}47.5 \\
=\end{array}$ & 1.1 & 3.4 & $\begin{array}{l}47.6 \\
=\end{array}$ & 1.6 & 1.8 \\
\hline & & $?-55.5$ & & & - & - & & & - & & \\
\hline Matuyama/Gauss- & $2.48-3.07$ & $\begin{array}{r}60.2-80.5 \\
?-83.4\end{array}$ & 19.3 & 3.3 & ${ }_{-}^{1.65}$ & $\stackrel{44.8}{-}$ & 1.15 & 3.8 & $\begin{array}{l}49.9 \\
-\end{array}$ & 1.9 & 1.9 \\
\hline top of Mammoth & & $\begin{array}{r}?-79.2 \\
55.5-73.7\end{array}$ & & & $\overline{65}$ & - & & & $=$ & & \\
\hline & & $80.6-89.4$ & & & 1.7 & 41.5 & & & 47.2 & & \\
\hline Top of Mammoth- & $3.07-3.40$ & $83.4-91.9$ & 8.6 & 2.6 & 1.7 & 43.6 & 1.2 & 3.1 & 50.5 & 1.5 & 1.6 \\
\hline Gauss/Gilbert & & $\begin{array}{l}79.2-? \\
73.7-?\end{array}$ & & & $=$ & $\overline{-}$ & & & $\overline{-}$ & & \\
\hline & & $89.4-105.3$ & & & 1.7 & 42.2 & & & 45.1 & & \\
\hline Gauss/Gilbert- & $3.40-3.83$ & 91.9-? & 15.9 & 3.7 & 1.75 & 43.0 & 1.2 & 4.4 & 49.2 & 2.1 & 2.3 \\
\hline top of Cochiti & & $? ?$ & & & $=$ & $\overline{-}$ & & & $\overline{-}$ & & \\
\hline & & 105.3-? & & & 1.7 & 41.5 & & & 38.0 & & \\
\hline Top of Cochiti- & $3.83-4.35$ & $?$ & 16.8 & 3.2 & - & - & 1.2 & 3.8 & - & 1.4 & 2.4 \\
\hline top of Gilbert $C_{1}$ & & $?$ & & & - & - & & & - & & \\
\hline & & $101.1-117.9$ & & & $\begin{array}{l}1.75 \\
1.75\end{array}$ & $\overline{43.7}$ & & & $\overline{313}$ & & \\
\hline Top of Gilbert $C_{1}-$ & $4.35-4.71$ & $?-135.2$ & 17.3 & 4.8 & - & - & 1.2 & 5.75 & - & 1.75 & 4.0 \\
\hline bottom of Gilbert $C_{2}$ & & & & & - & - & & & - & & \\
\hline & & 117.9-? & & & $\overline{-\pi}$ & - & & & - & & \\
\hline Bottom of Gilbert $C_{2}-$ & $4.71-6.5$ & $135.2-196.3$ & 60.6 & 34 & 1.75 & $\begin{array}{l}40.5 \\
-\end{array}$ & 1.25 & 4.2 & $\begin{array}{c}29.4 \\
-\end{array}$ & 12 & 3.0 \\
\hline base of $A$. primus & $4.71-0.5$ & $?$ & 00.0 & & $\overline{-}$ & - & & 4.2 & $\overline{-}$ & & 3.0 \\
\hline & & ?- & & & - & - & & & - & & \\
\hline & $6.5-73$ & 196.3-? & 30 & 38 & - & $\overline{-}$ & 12 & 45 & $\overline{-}$ & 0.9 & 3.6 \\
\hline base of $D$. neorectus & & 195.8-? & & 3.8 & $\overline{-}$ & $=$ & 1.2 & & $=$ & 0.9 & 3.0 \\
\hline & & -226 & & & 1.6 & 38.0 & & & 20.0 & & \\
\hline
\end{tabular}

Depth interval for each time slice is shown for each hole, in order; 502 through $502 \mathrm{C}$.

b Mean thickness computed only when both boundaries of a time slice were recovered.

c Wet-bulk density from GRAPE data.

d Calculated dry-bulk density: $\delta_{\mathrm{d}}-\delta_{\mathrm{w}} /(1+\% \mathrm{wc})$.

e Bulk accumulation rate $=$ sedimentation $\times \delta_{\mathrm{d}}$.

f Accumulation rate of $\mathrm{CaCO}_{3}=$ bulk accumulation rate $\times \% \mathrm{CaCO}_{3}$; noncarbonate rate $=$ bulk $-\mathrm{CaCO}_{3}$ rate.

\section{GEOCHEMICAL MEASUREMENTS}

Routine analyses were made only for salinity of interstitial water from Holes 502B and 502C. Salinity of interstitial water shows an increase in Hole 502B from an initial value of $35.5 \%$ at 2 meters sub-bottom to a maximum value of $39.6 \%$ at 14.5 meters. Salinity decreases to $37.4 \%$ between 14.5 and 27.5 meters and then increases to $38.2 \%$ below 27.5 meters. We can find no correlation of any observed parameter with these salinity changes.

Salinity remains fairly constant in Hole $502 \mathrm{C}$ from a sub-bottom depth of 37 down to 143.5 meters, with a range between $34.5 \%$ and $36.6 \%$. The one exception occurs at a depth of 135 meters, where it reaches the anomalously high value of $39.6 \%$.

\section{SUMMARY AND CONCLUSIONS}

Site 502 is located on a horst in the Colombia Basin in the vicinity of Site 154 . The location of Site 502 was

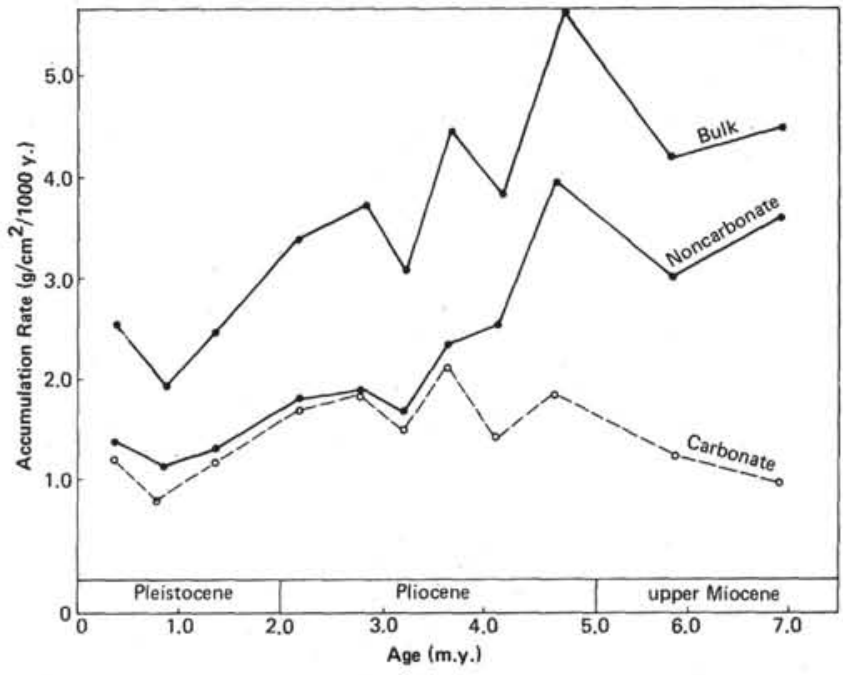

Figure 18. Bulk, noncarbonate, and carbonate accumulation rates $(\mathrm{g} /$ $\mathrm{cm}^{2} 1000$ y.) versus time at Site 502. 
chosen in an area that has a thick, acoustically transparent section without the distinct reflector that was found to be volcanogenic turbidites at Site 154. Site 502 consists of four holes, all cored within about 200 meters of each other to a maximum depth of 227 meters sub-bottom. The holes were all cored using the Hydraulic Piston Corer (HPC), and the sediment recovered represents in composite, a nearly continuous, almost totally undisturbed section for at least the past $7.8 \mathrm{~m}$.y. (Holocene to early late Miocene).

Our objective at Site 502 was to recover an undisturbed, complete section of Quaternary and Neogene sediment that would permit a wide variety of detailed studies of the paleoclimatic, paleoceanographic, and tectonic history of the western Caribbean Sea. We recovered a nearly complete, undisturbed record that extends from early late Miocene through Holocene. Figure 19 shows a summary of core recovery, lithostratigraphy, magnetostratigraphy, biostratigraphy, age, and calculated accumulation rates of this section.

The sediment from Site 502 consists of foraminiferbearing nannofossil marl that grades to calcareous clay with depth. The top seven meters of the section is yellowish brown, but the remainder is various shades of gray to greenish gray. The latter colors indicate reduced conditions, and because the upper section is oxidized, we feel that post depositional reduction of the sediment is pervasive. The sediment seldom exceeds $60 \% \mathrm{CaCO}_{3}$, indicating a significant influence from terrigenous sources throughout the Neogene and Quaternary. However, cyclic accumulation of carbonate is apparent throughout the entire section.

The succession of nannofossil and planktonic foraminiferal biostratigraphic zones and biohorizons at Site 502 (see Fig. 16) indicate that we recovered a complete biostratigraphic section from the late Miocene to the Holocene. All 19 major paleomagnetic chrons and subchrons of the Pliocene and Quaternary were also identified (Fig. 17). We believe this is the first time all magnetozones have been recognized in one section. In addition to the major paleomagnetic events, several excursions of the field were observed within the Matuyama Chron. These normal polarity excursions are up to $30 \mathrm{~cm}$ long, and two of them may correlate to the Cobb Mt. and Reunion Subchrons.

The combination of biostratigraphy and magnetostratigraphy reveals that deposition at Site 502 has been continuous over the past $7.5 \mathrm{~m} . \mathrm{y}$. and that accumulation rates have been relatively high (about $3 \mathrm{~cm} / \mathrm{k}$.y.). This high-quality record has enabled us to examine the detailed history of sedimentary components in the late Neogene and Quaternary.

\section{REFERENCES}

Burckle, L. H., 1972. Late Cenozoic planktonic diatom zones from the eastern equatorial Pacific. Nova Hedwigia Beiheft, 39:217-246.

Demars, K. R., and Nacci, V. A., 1978. Significance of Deep Sea Drilling Project sediment physical property data. Mar. Geotechnol., 3(No. 2):151-170.

Edgar, N. T., Saunders, J. B., et al., 1973. Site 154. In Edgar, N. T., Saunders, J. B., et al., Init. Repts. DSDP, 15: Washington (U.S. Govt. Printing Office), 407-471.

Gartner, S., 1977. Calcareous nannofossil biostratigraphy and revised zonation of the Pleistocene. Mar. Micropaleo., 2:1-25.

Haq, B. U., Worsley, T. R., Burckle, L. H., Douglas, R. G., Keigwin, L. D., Jr., Opdyke, N. D., Savin, S. M., Sommer, M. A., Vincent, E., and Woodruff, F., 1980. Late Miocene marine carbon isotopic shift and synchroneity of some phytoplanktonic biostratigraphic events. Geology, 8:427-431.

Heath, G. R., 1969. Mineralogy of Cenozoic deep-sea sediments from the Equatorial Pacific Ocean. Geol. Soc. Am. Bull., 80:1997-2018.

Jenkins, G. D., and Orr, W. N., 1972. Planktonic foraminiferal biostratigraphy of the eastern equatorial Pacific, Leg 9. In Hays et al., Init. Repts. DSDP, 9: Washington (U.S. Govt. Printing Office), 1059-1205.

Keigwin, L. D., Jr., 1978. Pliocene closing of the Isthmus of Panama, based on biostratigraphic evidence from nearby Pacific Ocean and Caribbean Sea cores. Geology, v. 6:630-634.

Lee, H. J., 1973. Measurements and estimates of engineering and other physical properties, Leg 19. In Creager, J. S., Scholl, D. W., et al., Init. Repts. DSDP, 19: Washington (U.S. Govt. Printing Office), 701-720.

Mayer, L. A., 1979. Deep-sea carbonates: acoustic, physical, and stratigraphic properties. J. Sed. Pet., 49:819-836.

Prell, W. L., 1978. Upper Quaternary sediments of the Colombia Basin: spatial and stratigraphic variation. Geol. Soc. Am. Bull., 89: 1241-1255.

Riedel, W. R., and Sanfilippo, A., 1973. Cenozoic radiolaria from the Caribbean, Deep Sea Drilling Project. In Edgar, N. T., Saunders, J. B., et al., Init. Repts. DSDP, 15: Washington (U.S. Govt. Printing Office), 705-751.

Sanfilippo, A., and Riedel, W. R., 1973. Cenozoic radiolaria (exclusive of theoperids, artostrobidds, and amphipyndacids) from the Gulf of Mexico, Deep Sea Drilling Project, Leg 10. In Worzel, J. L., Bryant, W., et al., Init. Repts. DSDP, 10: Washington (U.S. Govt. Printing Office), 475-611.

1976. Radiolarian occurrences in the Caribbean region. Publication de la VII Conférence Géologique des Caralbes (Cayenne, la Guyane), pp. 145-168.

van Andel, Tj. H., Heath, G. R., and Moore, T. C., Jr., 1975. Cenozoic history and paleoceanography of the central equatorial $\mathrm{Pa}$ cific Ocean. Geol. Soc. Am. Mem. 143. 

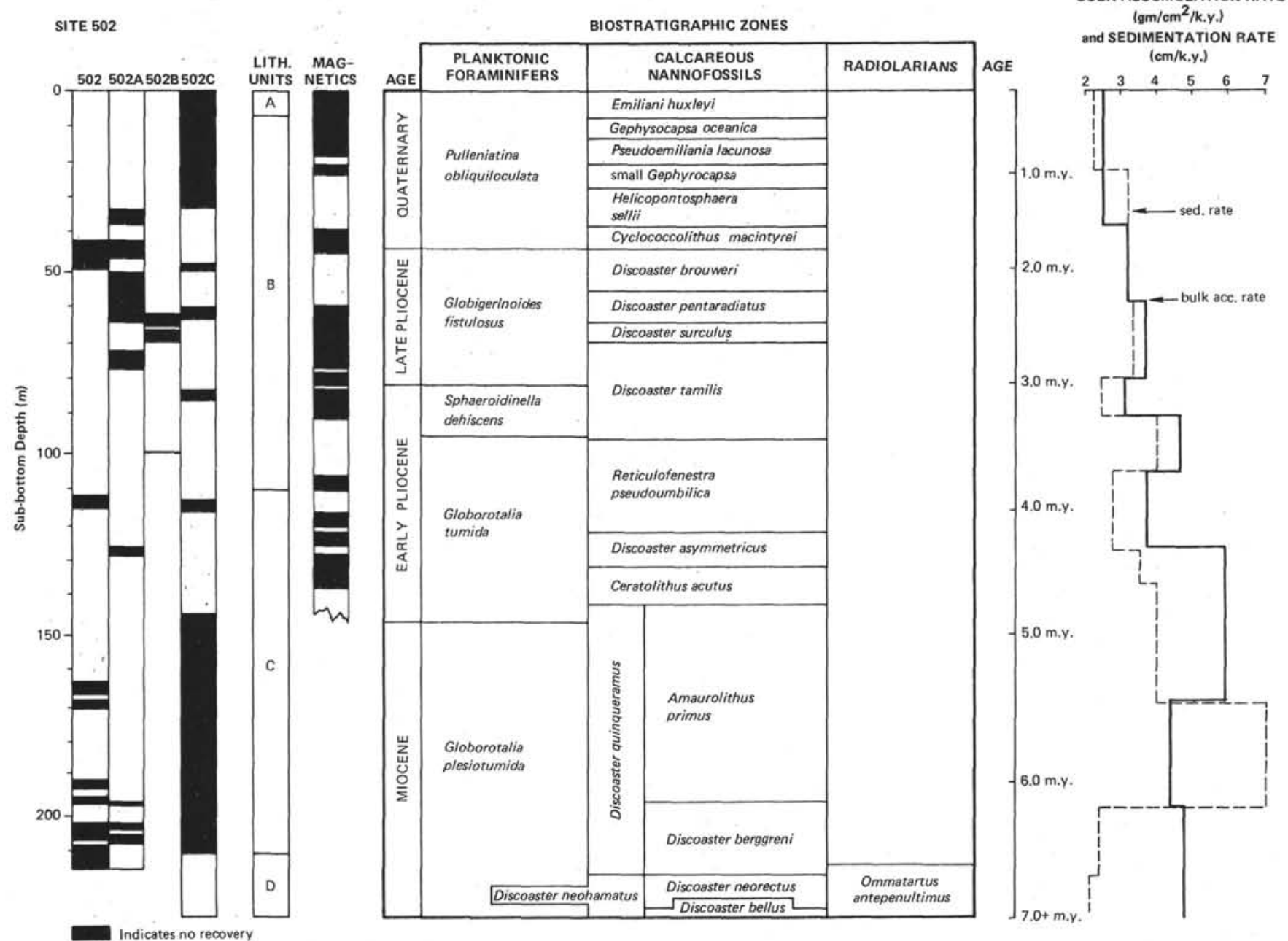

Figure 19. Summary of the recovery, lithostratigraphy, magnetostratigraphy, biostratigraphy, and sediment accumulation rates (given in Table 5) for Site 502. 


\section{APPENDIX}

Table 3. Smear slide summary of major and minor lithologies for Site 502. The estimates are qualitative, using $<5 \%$ estimate $=$ rare, $5-25 \%=$ common, $25-75 \%=$ abundant, and $>75 \%=$ dominant.

HOLE 502
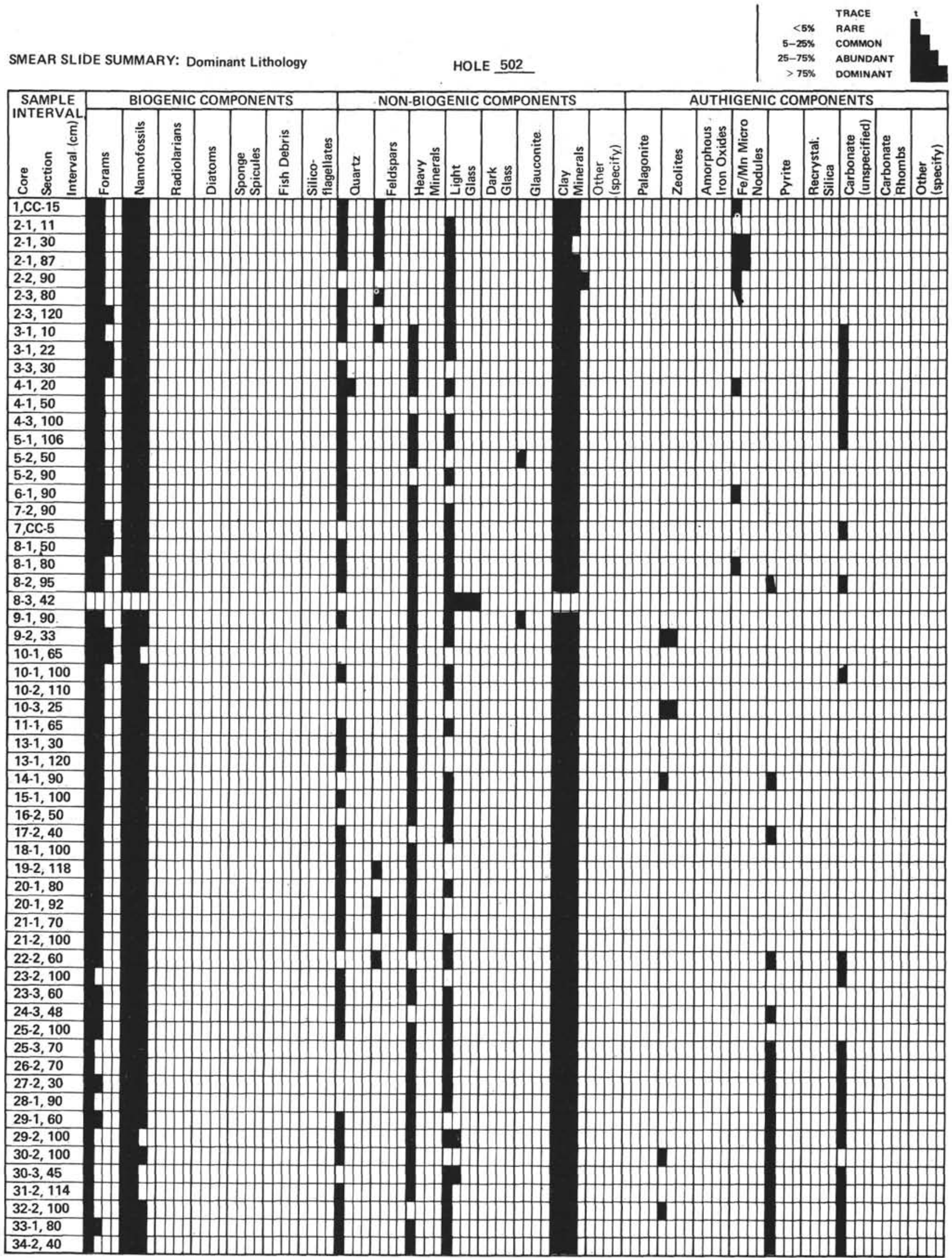
Table 3. (Continued).

SMEAR SLIDE SUMMARY: Dominant Lithology

HOLE 502

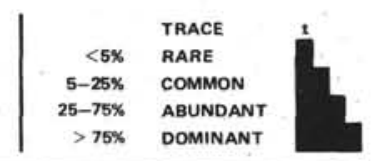

\begin{tabular}{|c|c|c|c|c|c|c|c|c|c|c|c|c|c|c|c|c|c|c|c|c|c|c|c|c|c|}
\hline SAMPLE & & $\mathrm{BIO}$ & ENI & $\mathrm{CON}$ & PONE & VTS & & & NOI & $\mathrm{BIOG}$ & ENIC & COMP & $\mathrm{ONE}$ & NTS & & & & AUTH & HIGENI & $\mathrm{C} \mathrm{CO}$ & MPON & NENTS & & & \\
\hline 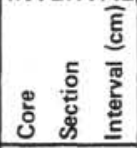 & हैं & 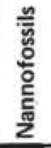 & 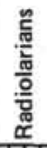 & 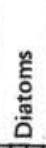 & 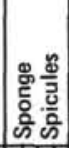 & 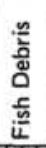 & 畩 & 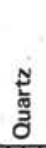 & 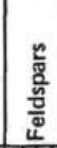 & 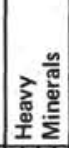 & 穿哭 & $\begin{array}{l}2 \\
\frac{2}{2} \\
0 \\
0\end{array}$ & 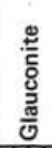 & 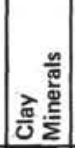 & 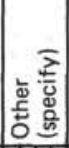 & 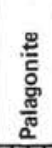 & 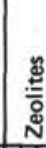 & 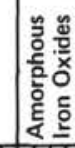 & 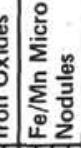 & है & 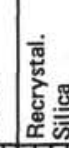 & 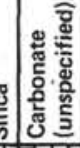 & & & 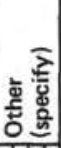 \\
\hline $34-2,90$ & & & & & & & & & & & & & & & & & & & & & & & & & \\
\hline $35-1,110$ & & & & & & & & & & & & & & & & & & & & & & & & & \\
\hline $36-1,74$ & & & & & & & & & & & & & & & & & & & & & & & & & \\
\hline $37 \cdot 1,100$ & & & & & & & & & & & & & & & & & & & & & & & & & \\
\hline $37 \cdot 2,90$ & & & & & & & & & & & & & & & & & & & & & & & & & \\
\hline $38-2,60$ & & & & & & & & & & & & & & & & & & & & & & & & & \\
\hline $39-1,70$ & & & & & & & & & & & & & & & & & & & & & & & & & \\
\hline $40-1,100$ & & & & & & & & & & & & & & & & & & & & & & & & & \\
\hline $41-1,130$ & & & & & & & & & & & & & & & & & & & & & & & & & \\
\hline $41-2,110$ & & & & & & & & & & & & & & & & & & & & & & & & & \\
\hline $42 \cdot 1$ & & & & & & & & & & & & & & & & & & & & & & & & & \\
\hline $42-2,130$ & & & & & & & & & & & & & & & & & & & & & & & & & \\
\hline $43-2,70$ & & & & & & & & & & & & & & & & & & & & & & & & & \\
\hline $43-2,80$ & & & & & & & & & & & & & & & & & & & & & & & & & \\
\hline $44-1,80$ & & & & & & & & & & & & & & & & & & & & & & & & & \\
\hline $45-1,80$ & & & & & & & & & & & & & & & & & & & & & & & & & \\
\hline $45-1,130$ & & & & & & & & & & & & & & & & & & & & & & & & & \\
\hline $46-1,135$ & & & & & & & & & & & & & & & & & & & & & & & & & \\
\hline $46-1,46$ & & & & & & & & & & & & & & & & & & & & & & & & & \\
\hline $46-1,75$ & & & & & & & & & & & & & & & & & & & & & & & & & \\
\hline $47-1,80$ & & & & & & & & & & & & & & & & & & & & & & & & & \\
\hline $47 \cdot 1,140$ & & & & & & & & & & & & & & & & & & & & & & & & & \\
\hline $48.1,60$ & & & & & & & & & & & & & & & & & & & & & & & & & \\
\hline $49-1,25$ & & & & & & & & & & & & & & & & & & & & & & & & & \\
\hline $50-1,20$ & & & & & & & & & & & & & & & & & & & & & & & & & \\
\hline
\end{tabular}


Table 3. (Continued).

\begin{tabular}{|c|c|c|c|c|c|c|c|c|c|c|c|c|c|c|c|c|c|c|c|c|c|c|c|c|}
\hline \multirow{2}{*}{ 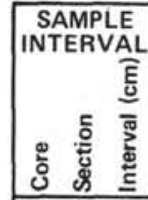 } & \multicolumn{7}{|c|}{ BIOGENIC COMPONENTS } & \multicolumn{8}{|c|}{ NON-BIOGENIC COMPONENTS } & \multicolumn{9}{|c|}{ AUTHIGENIC COMPONENTS } \\
\hline & & 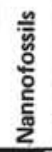 & 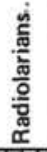 & 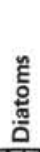 & 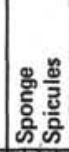 & 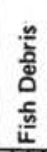 & 遮 & है & 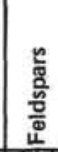 & 窟商 & 盇若 & $\begin{array}{l}\text { 总 } \\
\text { o. }\end{array}$ & 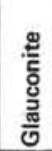 & 严竞 & 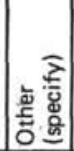 & 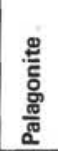 & 兽 & 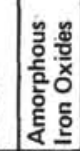 & 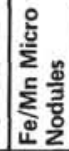 & 营 & 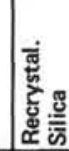 & 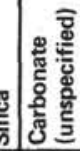 & 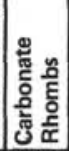 & 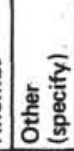 \\
\hline \multicolumn{25}{|l|}{$3-1,22$} \\
\hline \multicolumn{25}{|l|}{$3.1,89$} \\
\hline \multicolumn{25}{|l|}{$3-2,101$} \\
\hline \multicolumn{25}{|l|}{$3-3,85$} \\
\hline \multicolumn{25}{|l|}{$4-2,47$} \\
\hline \multicolumn{25}{|l|}{$5 \cdot 1,77$} \\
\hline \multicolumn{25}{|l|}{$6-2,56$} \\
\hline \multicolumn{25}{|l|}{$15-1,84$} \\
\hline \multicolumn{25}{|l|}{$17-1,120$} \\
\hline \multicolumn{25}{|l|}{$20-3,40$} \\
\hline \multicolumn{25}{|l|}{$24-1,146$} \\
\hline \multicolumn{25}{|l|}{$27 \cdot 2,63$} \\
\hline \multicolumn{25}{|l|}{$29 \cdot 1,116$} \\
\hline \multirow{2}{*}{\multicolumn{25}{|c|}{$\begin{array}{l}30-3,39 \\
31-1,114\end{array}$}} \\
\hline \multirow{2}{*}{\multicolumn{25}{|c|}{$\begin{array}{l}31-1,114 \\
32-1,93\end{array}$}} \\
\hline & & & & & & & & & & & & & & & & & & & & & & & & \\
\hline \multicolumn{25}{|l|}{$32-1,100$} \\
\hline $32-1,129$ & & & & & & & & & & & & & & & & & & & & & & & & \\
\hline $39.1,76$ & & & & & & & & & & & & & & & & & & & & & & & & \\
\hline $40-1,47$ & & & & & & & & & & & & & & & & & & & & & & & & \\
\hline $40-1,55$ & & & & & & & & & & & & & & & & & & & & & & & & \\
\hline $40-1,76$ & & & & & & & & & & & & & & & & & & & & & & & & \\
\hline $40-1,149$ & & & & & & & & & & & & & & & & & & & & & & & & \\
\hline $41-2,68$ & & & & & & & & & & & & & & & & & & & & & & & & \\
\hline 441,108 & & & & & & & & & & & & & & & & & & & & & & & & \\
\hline $44-1,130$ & & & & & & & & & & & & & & & & & & & & & & & & \\
\hline 44, CC-27 & & & & & & & & & & & & & & & & & & & & & & & & \\
\hline $45 \cdot 1,43$ & & & & & & & & & & & & & & & & & & & & & & & & \\
\hline $45-1,46$ & & & & & & & & & & & & & & & & & & & & & & & & \\
\hline $48-1,25$ & & & & & & & & & & & & & & & & & & & & & & & & \\
\hline $48-1,106$ & & & & & & & & & & & & & & & & & & & & & & & & \\
\hline $50 \cdot 1,27$ & & & & & & & & & & & & & & & & & & & & & & & & \\
\hline
\end{tabular}


Table 3. (Continued).

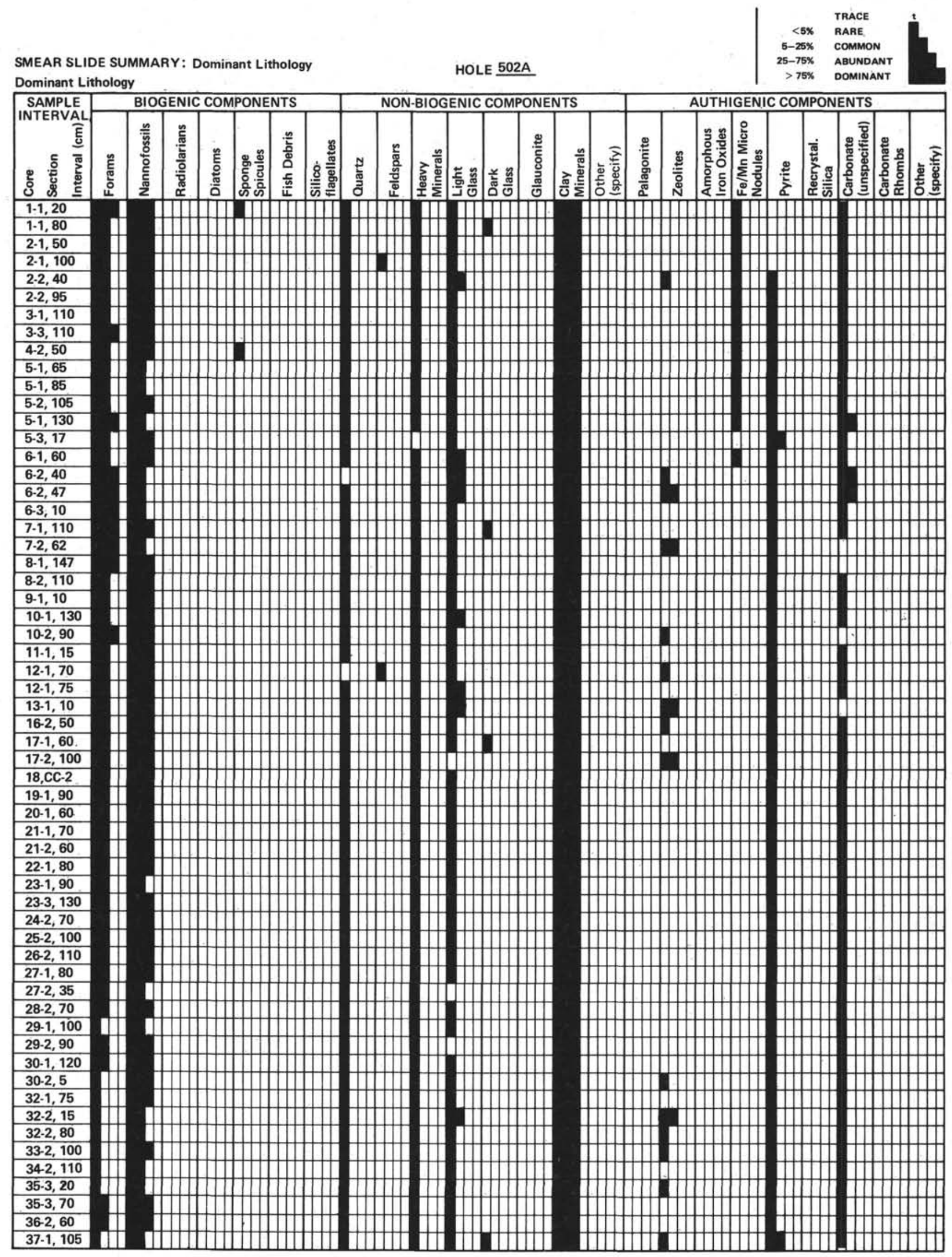


Table 3. (Continued).

SMEAR SLIDE SUMMARY: Dominant Lithology

HOLE $\underline{502 A}$

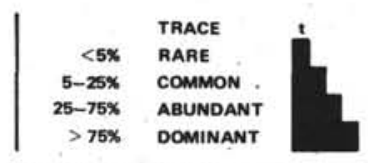

\begin{tabular}{|c|c|c|c|c|c|c|c|c|c|c|c|c|c|c|c|c|c|c|c|c|c|c|c|c|}
\hline \multirow{2}{*}{ 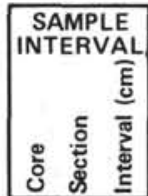 } & \multicolumn{7}{|c|}{ BIOGENIC COMPONENTS } & \multicolumn{8}{|c|}{ NON-BIOGENIC COMPONENTS } & \multicolumn{9}{|c|}{ AUTHIGENIC COMPONENTS } \\
\hline & है & 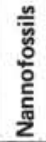 & 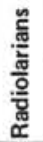 & 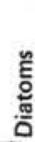 & 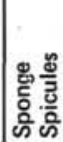 & 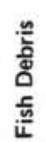 & 惫 & वै & 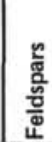 & 离 & 奇兽 & 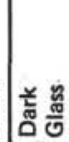 & 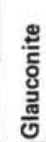 & 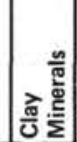 & 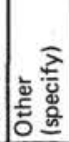 & 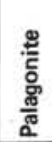 & $\begin{array}{l}\stackrel{\mathscr{E}}{\circ} \\
\text { N } \\
\text { N }\end{array}$ & 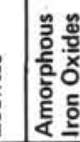 & 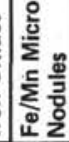 & ؛ั & 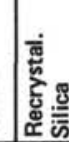 & 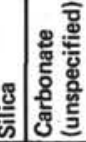 & 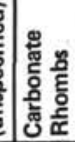 & 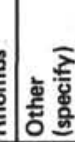 \\
\hline $37.2,90$ & & & & & & & & & & & & & & & & & & & & & & & & \\
\hline $38-1,90$ & & & & & & & & & & & & & & & & & & & & & & & & \\
\hline $39 \cdot 1,110$ & & & & & & & & & & & & & & & & & & & & & & & & \\
\hline $40 \cdot 1,100$ & & & & & & & & & & & & & & & & & & & & & & & & \\
\hline $40-2,90$ & & & & & & & & & & & & & & & & & & & & & & & & \\
\hline $41-2,100$ & & & & & & & & & & & & & & & & & & & & & & & & \\
\hline $42-1,100$ & & & & & & & & & & & & & & & & & & & & & & & & \\
\hline $43-1,70$ & & & & & & & & & & & & & & & & & & & & & & & & \\
\hline $43-2,5$ & & & & & & & & & & & & & & & & & & & & & & & & \\
\hline 442,60 & & & & & & & & & & & & & & & & & & & & & & & & \\
\hline $45-1,80$ & & & & & & & & & & & & & & & & & & & & & & & & \\
\hline $46-2,15$ & & & & & & & & & & & & & & & & & & & & & & & & \\
\hline $46-2,50$ & & & & & & & & & & & & & & & & & & & & & & & & \\
\hline $47-1,120$ & & & & & & & & & & & & & & & & & & & & & & & & \\
\hline $47-2,100$ & & & & & & & & & & & & & & & & & & & & & & & & \\
\hline $48-1,60$ & & & & & & & & & & & & & & & & & & & & & & & & \\
\hline $48-1,130$ & & & & & & & & & & & & & & & & & & & & & & & & \\
\hline $50-1,130$ & & & & & & & & & & & & & & & & & & & & & & & & \\
\hline $50-2,40$ & & & & & & & & & & & & & & & & & & & & & & & & \\
\hline $51-1,60$ & & & & & & & & & & & & & & & & & & & & & & & & \\
\hline $51-2,50$ & & & & & & & & & & & & & & & & & & & & & & & & \\
\hline $52-1,87$ & & & & & & & & & & & & & & & & & & & & & & & & \\
\hline $52-1,120$ & & & & & & & & & & & & & & & & & & & & & & & & \\
\hline $53-1,70$ & & & & & & & & & & & & & & & & & & & & & & & & \\
\hline $54-2,10$ & & & & & & & & & & & & & & & & & & & & & & & & \\
\hline $54-2,60$ & & & & & & & & & & & & & & & & & & & & & & & & \\
\hline $55-1,35$ & & & & & & & & & & & & & & & & & & & & & & & & \\
\hline $55-1,90$ & & & & & & & & & & & & & & & & & & & & & & & & \\
\hline $55-1,90$ & & & & & & & & & & & & & & & & & & & & & & & & \\
\hline $55-1,120$ & & & & & & & & & & & & & & & & & & & & & & & & \\
\hline $57 \cdot 1,120$ & & & & & & & & & & & & & & & & & & & & & & & & \\
\hline $57-2,20$ & & & & & & & & & & & & & & & & & & & & & & & & \\
\hline $58-1,147$ & & & & & & & & & & & & & & & & & & & & & & & & \\
\hline $58-1,95$ & & & & & & & & & & & & & & & & & & & & & & & & \\
\hline $59, \mathrm{CC}-10$ & & & & & & & & & & & & & & & & & & & & & & & & \\
\hline $59, \mathrm{CC}-20$ & & & & & & & & & & & & & & & & & & & & & & & & \\
\hline $60-1,80$ & & & & & & & & & & & & & & & & & & & & & & & & \\
\hline $60-1,110$ & & & & & & & & & & & & & & & & & & & & & & & & \\
\hline $61-1,50$ & & & & & & & & & & & & & & & & & & & & & & & & \\
\hline $61-1,80$ & & & & & & & & & & & & & & & & & & & & & & & & \\
\hline $62-1,42$ & & & & & & & & & & & & & & & & & & & & & & & & \\
\hline $63-1,60$ & & & & & & & & & & & & & & & & & & & & & & & & \\
\hline $63-1,130$ & & & & & & & & & & & & & & & & & & & & & & & & \\
\hline $65-1,35$ & & & & & & & & & & & & & & & & & & & & & & & & \\
\hline $65-2,30$ & & & & & & & & & & & & & & & & & & & & & & & & \\
\hline $66-1,90$ & & & & & & & & & & & & & & & & & & & & & & & & \\
\hline $66-2,30$ & & & & & & & & & & & & & & & & & & & & & & & & \\
\hline $67-1,50$ & & & & & & & & & & & & & & & & & & & & & & & & \\
\hline $68-1,82$ & & & & & & & & & & & & & & & & & & & & & & & & \\
\hline $68 \cdot 2,50$ & & & & & & & & & & & & & & & & & & & & & & & & \\
\hline
\end{tabular}


Table 3. (Continued).

SMEAR SLIDE SUMMARY : Minor Lithology

HOLE 502A
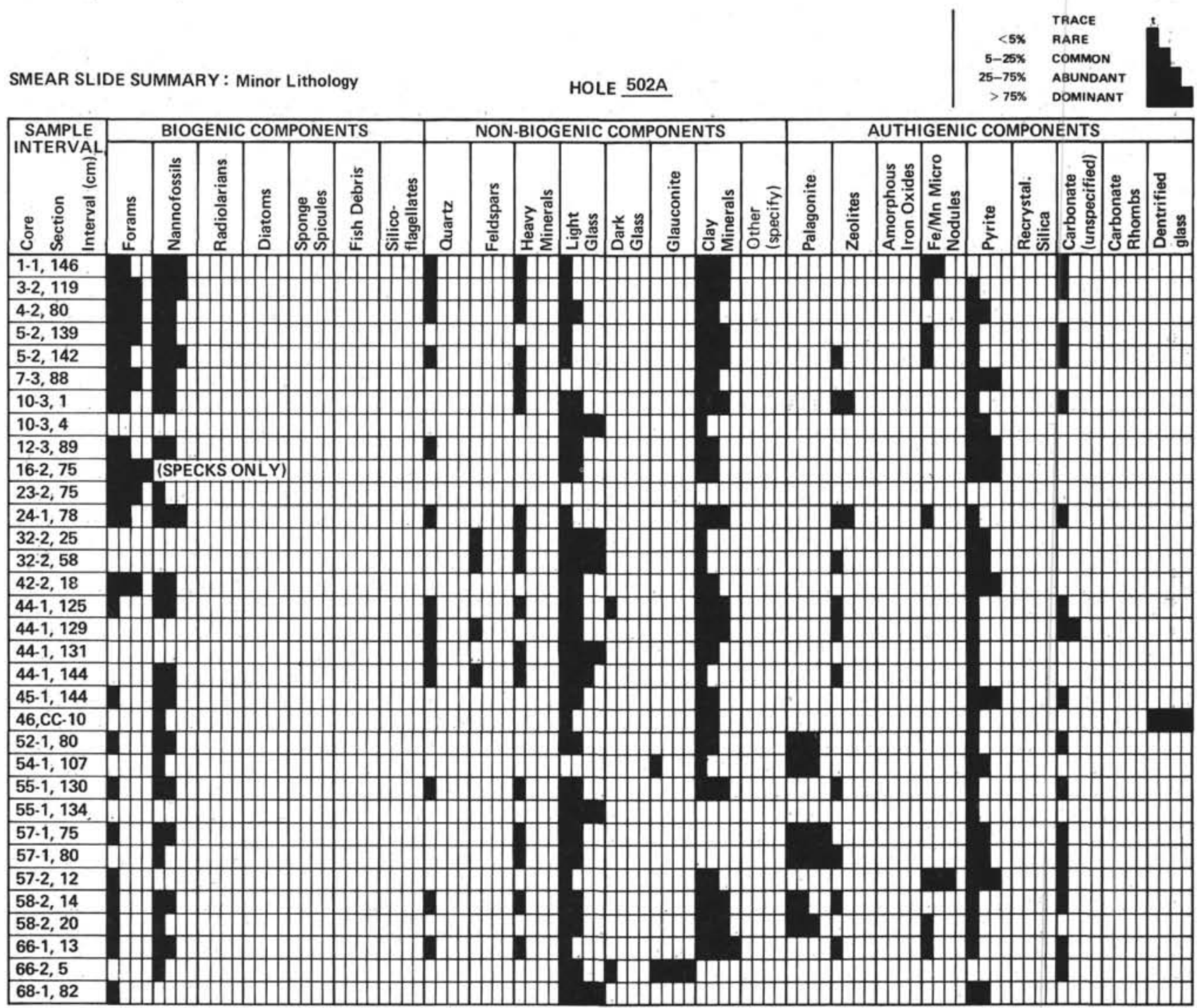
Table 3. (Continued).

SMEAR SLIDE SUMMARY: Dominant Lithology

HOLE 502B

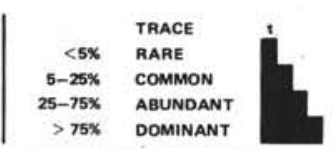

\begin{tabular}{|c|c|c|c|c|c|c|c|c|c|c|c|c|c|c|c|c|c|c|c|c|c|c|c|c|}
\hline \multirow{2}{*}{ 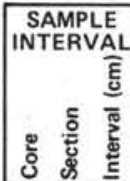 } & \multicolumn{7}{|c|}{ BIOGENIC COMPONENTS } & \multicolumn{8}{|c|}{ NON-BIOGENIC COMPONENTS } & \multicolumn{9}{|c|}{ AUTHIGENIC COMPONENTS } \\
\hline & 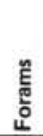 & 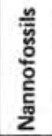 & 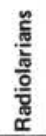 & $\begin{array}{l}\text { है } \\
\text { है } \\
\text { क्ष }\end{array}$ & 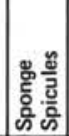 & 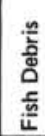 & 离 & 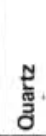 & 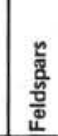 & 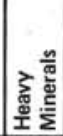 & $\frac{\mathrm{E}}{0}$ & 关恕 & 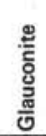 & 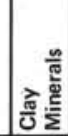 & 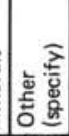 & 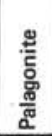 & 产 & 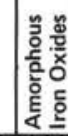 & 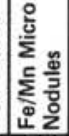 & 总 & 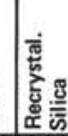 & 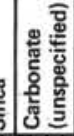 & 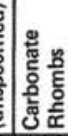 & 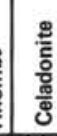 \\
\hline $1-1,80$ & & & & & & & & & & & & & & & & & & & & & & & & \\
\hline $1-1,136$ & & & & & & & & & & & & & & & & & & & & & & & & \\
\hline $2 \cdot 1,90$ & & & & & & & & & & & & & & & & & & & & & & & & \\
\hline $2-2,47$ & & & & & & & & & & & & & & & & & & & & & & & & \\
\hline $2 \cdot 3,50$ & & & & & & & & & & & & & & & & & & & & & & & & \\
\hline $3-1,110$ & & & & & & & & & & & & & & & & & & & & & & & & \\
\hline $3-2,23$ & & & & & & & & & & & & & & & & & & & & & & & & \\
\hline $3-3,10$ & & & & & & & & & & & & & & & & & & & & & & & & \\
\hline $3-3,110$ & & & & & & & & & & & & & & & & & & & & & & & & \\
\hline $4-1,5$ & & & & & & & & & & & & & & & & & & & & & & & & \\
\hline $4-1,110$ & & & & & & & & & & & & & & & & & & & & & & & & \\
\hline $5-1,90$ & & & & & & & & & & & & & & & & & & & & & & & & \\
\hline $5 \cdot 2,105$ & & & & & & & & & & & & & & & & & & & & & & & & \\
\hline $5-3,92$ & & & & & & & & & & & & & & & & & & & & & & & & \\
\hline $6-1,16$ & & & & & & & & & & & & & & & & & & & & & & & & \\
\hline $6-2,80$ & & & & & & & & & & & & & & & & & & & & & & & & \\
\hline $7 \cdot 3,65$ & & & & & & & & & & & & & & & & & & & & & & & & \\
\hline $7 \cdot 3,90$ & & & & & & & & & & & & & & & & & & & & & & & & \\
\hline $8-1,95$ & & & & & & & & & & & & & & & & & & & & & & & & \\
\hline $8 \cdot 2,130$ & & & & & & & & & & & & & & & & & & & & & & & & \\
\hline $8-3,30$ & & & & & & & & & & & & & & & & & & & & & & & & \\
\hline $9-1,140$ & & & & & & & & & & & & & & & & & & & & & & & & \\
\hline $9.2,60$ & & & & & & & & & & & & & & & & & & & & & & & & \\
\hline $9 \cdot 3,10$ & & & & & & & & & & & & & & & & & & & & & & & & \\
\hline $10-2,48$ & & & & & & & & & & & & & & & & & & & & & & & & \\
\hline $11-1,120$ & & & & & & & & & & & & & & & & & & & & & & & & \\
\hline $11-2,26$ & & & & & & & & & & & & & & & & & & & & & & & & \\
\hline $12-3,30$ & & & & & & & & & & & & & & & & & & & & & & & & \\
\hline 13-2, 81 & & & & & & & & & & & & & & & & & & & & & & & & \\
\hline 141,80 & & & & & & & & & & & & & & & & & & & & & & & & \\
\hline $14-1,130$ & & & & & & & & & & & & & & & & & & & & & & & & \\
\hline $15-1,54$ & & & & & & & & & & & & & & & & & & & & & & & & \\
\hline $15-1,90$ & & & & & & & & & & & & & & & & & & & & & & & & \\
\hline $16-1,80$ & & & & & & & & & & & & & & & & & & & & & & & & \\
\hline $17 \cdot 1,70$ & & & & & & & & & & & & & & & & & & & & & & & & \\
\hline $17-2,124$ & & & & & & & & & & & & & & & & & & & & & & & & \\
\hline $18-2,60$ & & & & & & & & & & & & & & & & & & & & & & & & \\
\hline $19-2,80$ & & & & & & & & & & & & & & & & & & & & & & & & \\
\hline $20-1,110$ & & & & & & & & & & & & & & & & & & & & & & & & \\
\hline $20-3,2$ & & & & & & & & & & & & & & & & & & & & & & & & \\
\hline $21 \cdot 2,40$ & & & & & & & & & & & & & & & & & & & & & & & & \\
\hline $22 \cdot 2,110$ & & & & & & & & & & & & & & & & & & & & & & & & \\
\hline $22-4,100$ & & & & & & & & & & & & & & & & & & & & & & & & \\
\hline $23-1,110$ & & & & & & & & & & & & & & & & & & & & & & & & \\
\hline $23-2,90$ & & & & & & & & & & & & & & & & & & & & & & & & \\
\hline
\end{tabular}

SMEAR SLIDE SUMMARY: Minor Lithology

HOLE 502B

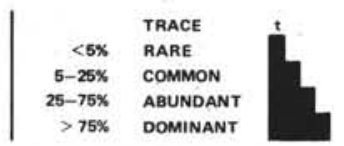

\begin{tabular}{|c|c|c|c|c|c|c|c|c|c|c|c|c|c|c|c|c|c|c|c|c|c|c|c|c|}
\hline \multirow{2}{*}{ 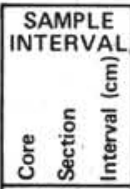 } & \multicolumn{7}{|c|}{ BIOGENIC COMPONENTS } & \multicolumn{8}{|c|}{ NON-BIOGENIC COMPONENTS } & \multicolumn{9}{|c|}{ AUTHIGENIC COMPONENTS } \\
\hline & $\begin{array}{l}\text { 总 } \\
\text { 운 }\end{array}$ & 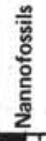 & 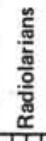 & है & 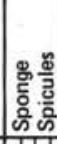 & 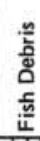 & 客 & $\begin{array}{l}\text { 跑 } \\
\text { בै }\end{array}$ & 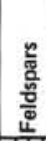 & 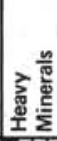 & 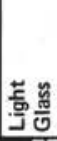 & 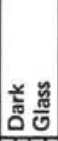 & 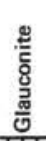 & 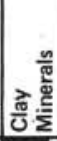 & 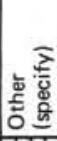 & 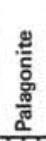 & 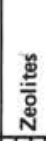 & 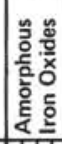 & 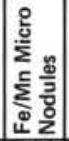 & 蓘 & 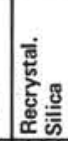 & 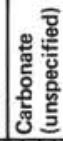 & 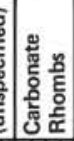 & 迹 \\
\hline $3-1,86$ & & & & & & & & & & & & & & & & U1] & & & & & & & & \\
\hline $4-2,95$ & & & & & & & & & & & & & & & & & & & & & & & & \\
\hline $5 \cdot 2,73$ & & & & & & & & & & & & & & & & & & & & & & & & \\
\hline $8 \cdot 2,40$ & & & & & & & & & & & & & & & & & & & & & & & & \\
\hline $8 \cdot 2,46$ & & & & & & & & & & & & & & & & & & & & & & & & \\
\hline $9 \cdot 2,33$ & & & & & & & & & & & & & & & & & & & & & & & & \\
\hline $20 \cdot 3,75$ & & & & & & & & & & & & & & & & & & & & & & & & \\
\hline
\end{tabular}


Table 3. (Continued).

SMEAR SLIDE SUMMARY: Dominant Lithology

HOLE $502 C$

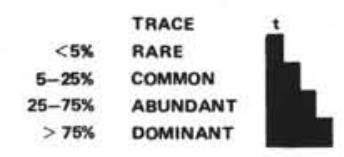

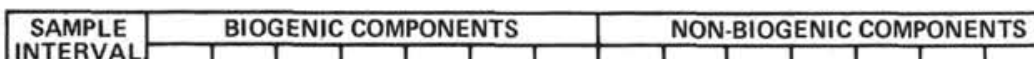

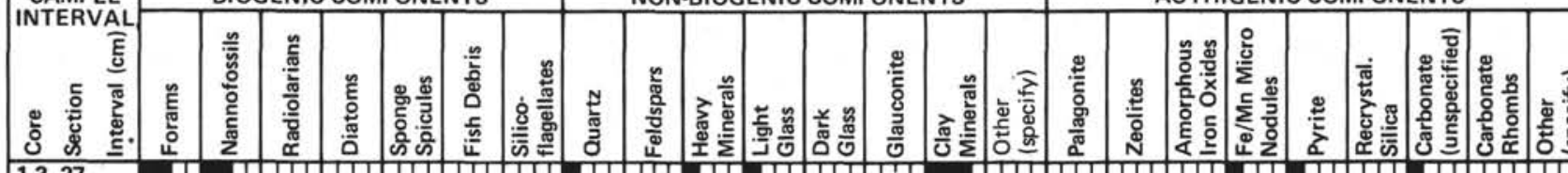

$1 \cdot 3,27$

$1-3,27$

$1 \cdot 3,110$

$2-3,60$

$2-3,80$

\begin{tabular}{|l|}
\hline$-1,80$ \\
\hline $3-2,21$
\end{tabular}

\begin{tabular}{|l|l}
\hline 41,130 \\
\hline $4-2,25$
\end{tabular}

$4-2,25$

\begin{tabular}{|l}
\hline $5-1,100$ \\
\hline $5-2,95$
\end{tabular}

$5-2,130$

6-2, 70

6-3, 5

7-1,60

8-3, 70

9-2, 70

$10-2,60$

$11-2,115$

$11-3,75$

$12-1,90$

$13-2,120$

$13-3,130$

$14-2,70$

143,60

$15-2,70$

$15-3,94$

16-1, 90

$16-3,115$

17-2, 145

17-3, 70

$18-1,80$

18-2, 55

$19-1,70$

$19-1,145$

20-1, 45

\begin{tabular}{|l|}
\hline $20-3,50$ \\
\hline $21-1,70$ \\
\hline
\end{tabular}

\begin{tabular}{|l}
$21-2,10$ \\
\hline $22-1,30$
\end{tabular}

\begin{tabular}{|l}
$22-1,30$ \\
\hline $22-2, C C$
\end{tabular}

23-1, 90

23-3, 50

$24-3,10$

$24-2$, 30

25-1, 65

25-1, 165

26-2, 60

26-2, 120

$27-2,50$

27-2, 95

28-2, 70

28-2, 55

29.2, 20

29-2, 80

$30-1,80$

$31-2,50$

$31-2,80$

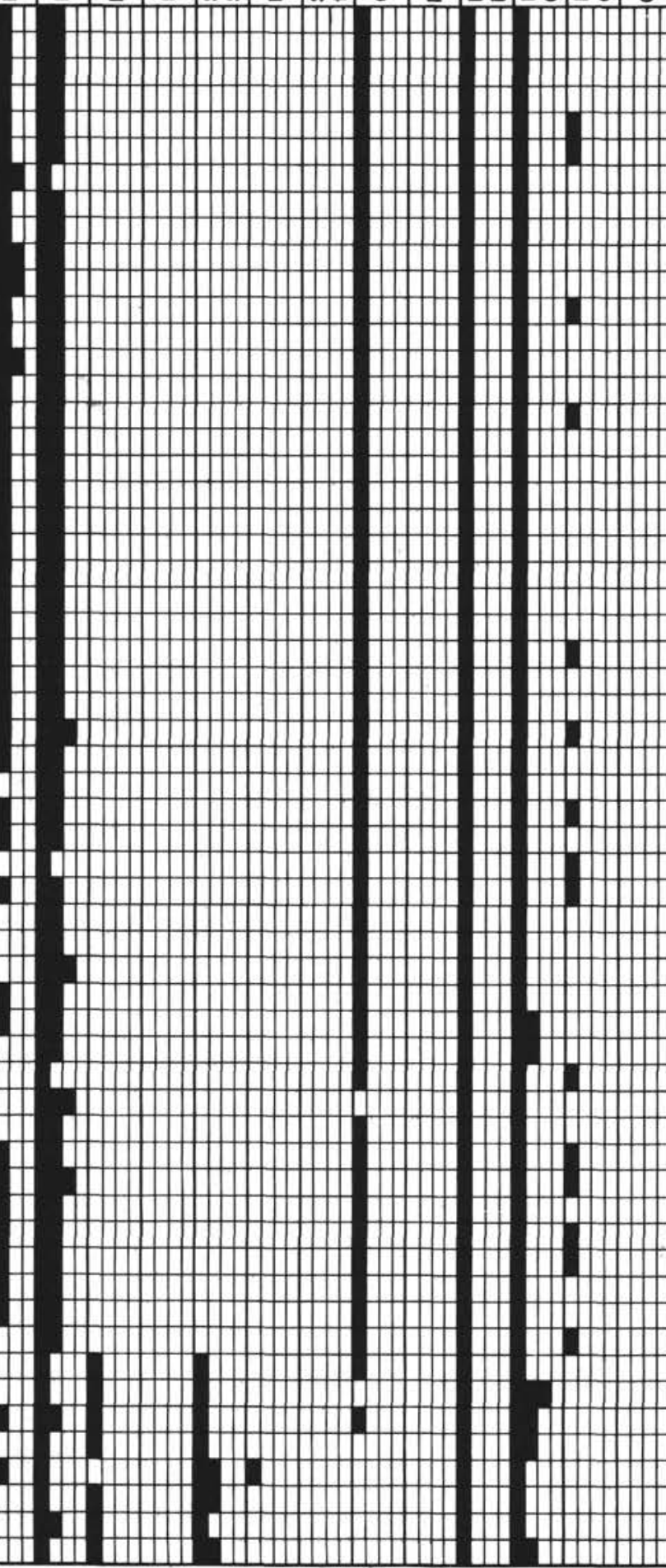

(1)


Table 3. (Continued).

\begin{tabular}{|c|c|c|c|c|c|c|c|c|c|c|c|c|c|c|c|c|c|c|c|c|c|c|c|c|}
\hline \multirow{2}{*}{ 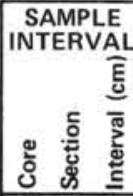 } & \multicolumn{7}{|c|}{ BIOGENIC COMPONENTS } & \multicolumn{8}{|c|}{ NON-BIOGENIC COMPONENTS } & \multicolumn{9}{|c|}{ AUTHIGENIC COMPONENTS } \\
\hline & & 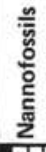 & 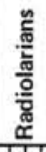 & 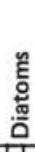 & 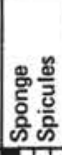 & 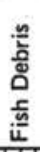 & 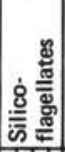 & $\begin{array}{l}\frac{N}{0} \\
\text { वี } \\
\text { वै }\end{array}$ & 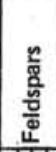 & 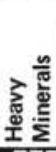 & 奇鵕 & $\begin{array}{l}\text { 前 } \\
\text { 爫 }\end{array}$ & 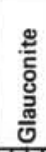 & 焉 & 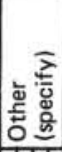 & 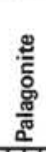 & 莣 & 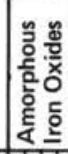 & 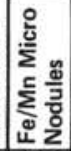 & 䒺 & 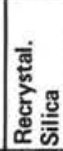 & 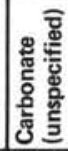 & 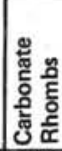 & 产 \\
\hline $33-1,100$ & & & & & & & & & & & & & & & & & & & & & & & & \\
\hline $34-1,90$ & & & & & & & & & & & & & & & & & & & & & & & & \\
\hline $34-2,50$ & & & & & & & & & & & & & & & & & & & & & & & & \\
\hline $35-1,55$ & & & & & & & & & & & & & & & & & & & & & & & & \\
\hline $35-1,80$ & & & & & & & & & & & & & & & & & & & & & & & & \\
\hline $36-1,25$ & & & & & & & & & & & & & & & & & & & & & & & & \\
\hline $37-1,5$ & & & & & & & & & & & & & & & & & & & & & & & & \\
\hline
\end{tabular}

SMEAR SLIDE SUMMARY: Minor Lithology

HOLE 502C

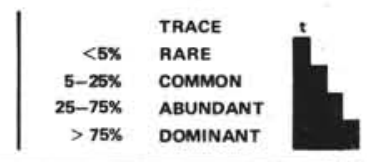

\begin{tabular}{|c|c|c|c|c|c|c|c|c|c|c|c|c|c|c|c|c|c|c|c|c|c|c|c|c|}
\hline \multirow{2}{*}{ 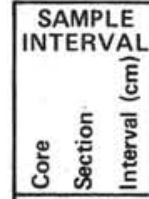 } & \multicolumn{7}{|c|}{ BIOGENIC COMPONENTS } & \multicolumn{8}{|c|}{ NON-BIOGENIC COMPONENTS } & \multicolumn{9}{|c|}{ AUTHIGENIC COMPONENTS } \\
\hline & & 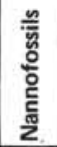 & 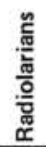 & 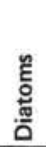 & 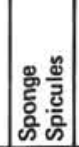 & 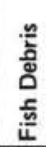 & 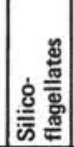 & 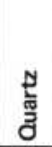 & 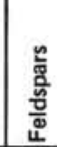 & 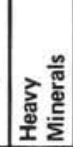 & 喜鵕 & 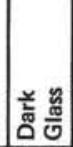 & 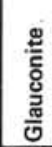 & 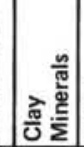 & 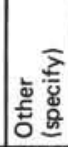 & 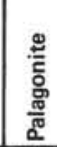 & 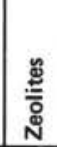 & 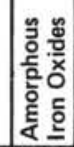 & 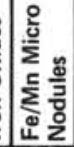 & 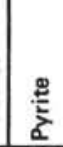 & 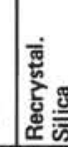 & 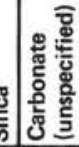 & 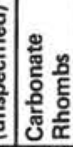 & 这 \\
\hline $3-2,43$ & & & & & & & & & & & & & & & & & & & & & & & & \\
\hline $14-1,141$ & & & & & & & & & & & & & & & & & & & & & & & & \\
\hline $14-2,135$ & & & & & & & & & & & & & & & & & & & & & & & & \\
\hline $14-3,104$ & & & & & & & & & & & & & & & & & & & & & & & & \\
\hline $15 \cdot 1,10$ & & & & & & & & & & & & & & & & & & & & & & & & \\
\hline $23-2,95$ & & & & & & & & & & & & & & & & & & & & & & & & \\
\hline $23-2,110$ & & & & & & & & & & & & & & & & & & & & & & & & \\
\hline $23-2,131$ & & & & & & & & & & & & & & & & & & & & & & & & \\
\hline $23-2,134$ & & & & & & & & & & & & & & & & & & & & & & & & \\
\hline $23-2,137$ & & & & & & & & & & & & & & & & & & & & & & & & \\
\hline $28-2,40$ & & & & & & & & & & & & & & & & & & & & & & & & \\
\hline $28-2,43$ & & & & & & & & & & & & & & & & & & & & & & & & \\
\hline $29 \cdot 1,40$ & & & & & & & & & & & & & & & & & & & & & & & & \\
\hline $30-1,18$ & & & & & & & & & & & & & & & & & & & & & & & & \\
\hline $32-1,14$ & & & & & & & & & & & & & & & & & & & & & & & & \\
\hline $32-1,98$ & & & & & & & & & & & & & & & & & & & & & & & & \\
\hline $32-1,106$ & & & & & & & & & & & & & & & & & & & & & & & & \\
\hline $32-1,113$ & & & & & & & & & & & & & & & & & & & & & & & & \\
\hline $33-1,87$ & & & & & & & & & & & & & & & & & & & & & & & & \\
\hline $33-2,44$ & & & & & & & & & & & & & & & & & & & & & & & & \\
\hline $33-2,50$ & & & & & & & & & & & & & & & & & & & & & & & & \\
\hline $35-1,72$ & & & & & & & & & & & & & & & & & & & & & & & & \\
\hline
\end{tabular}



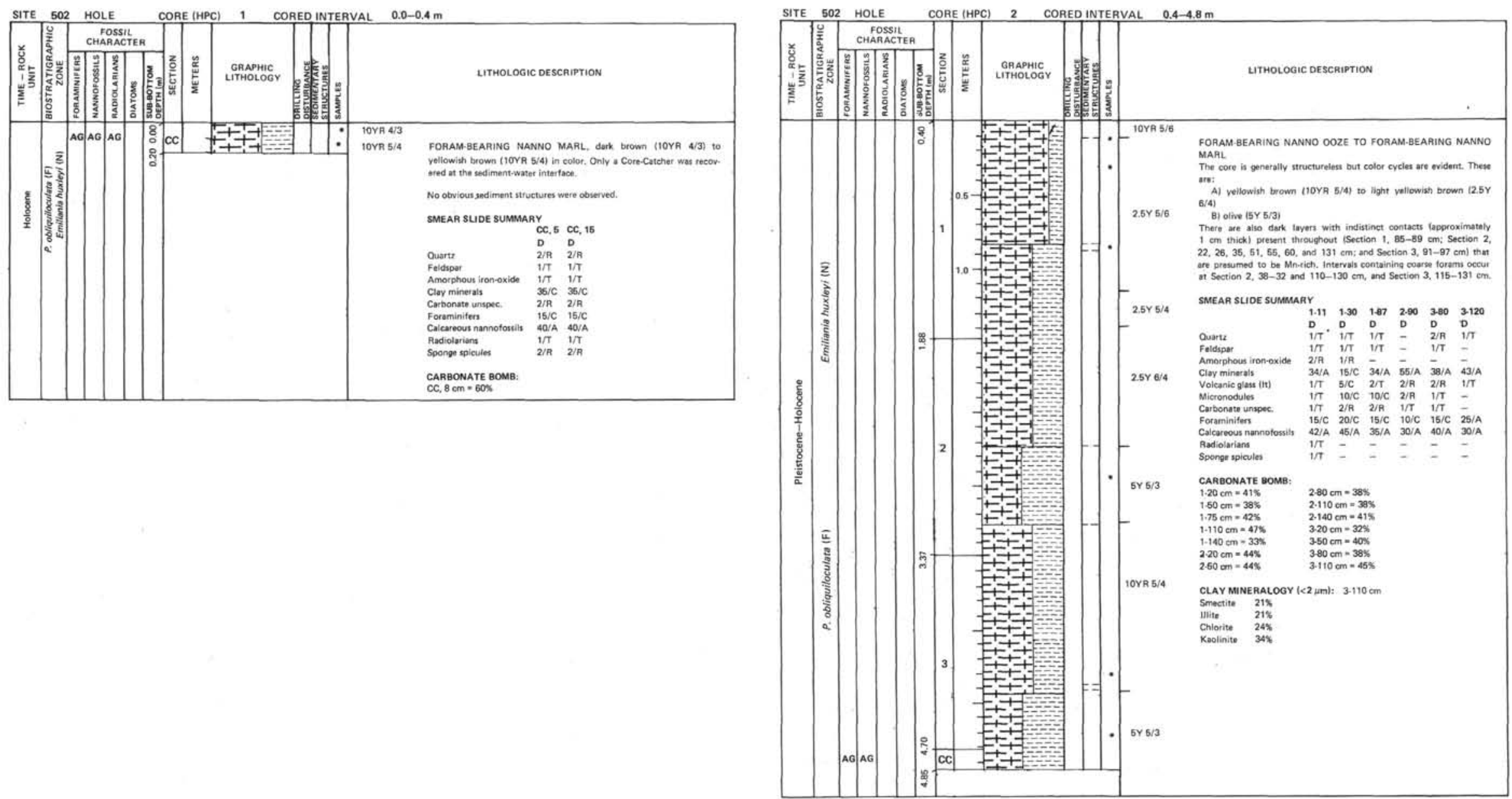

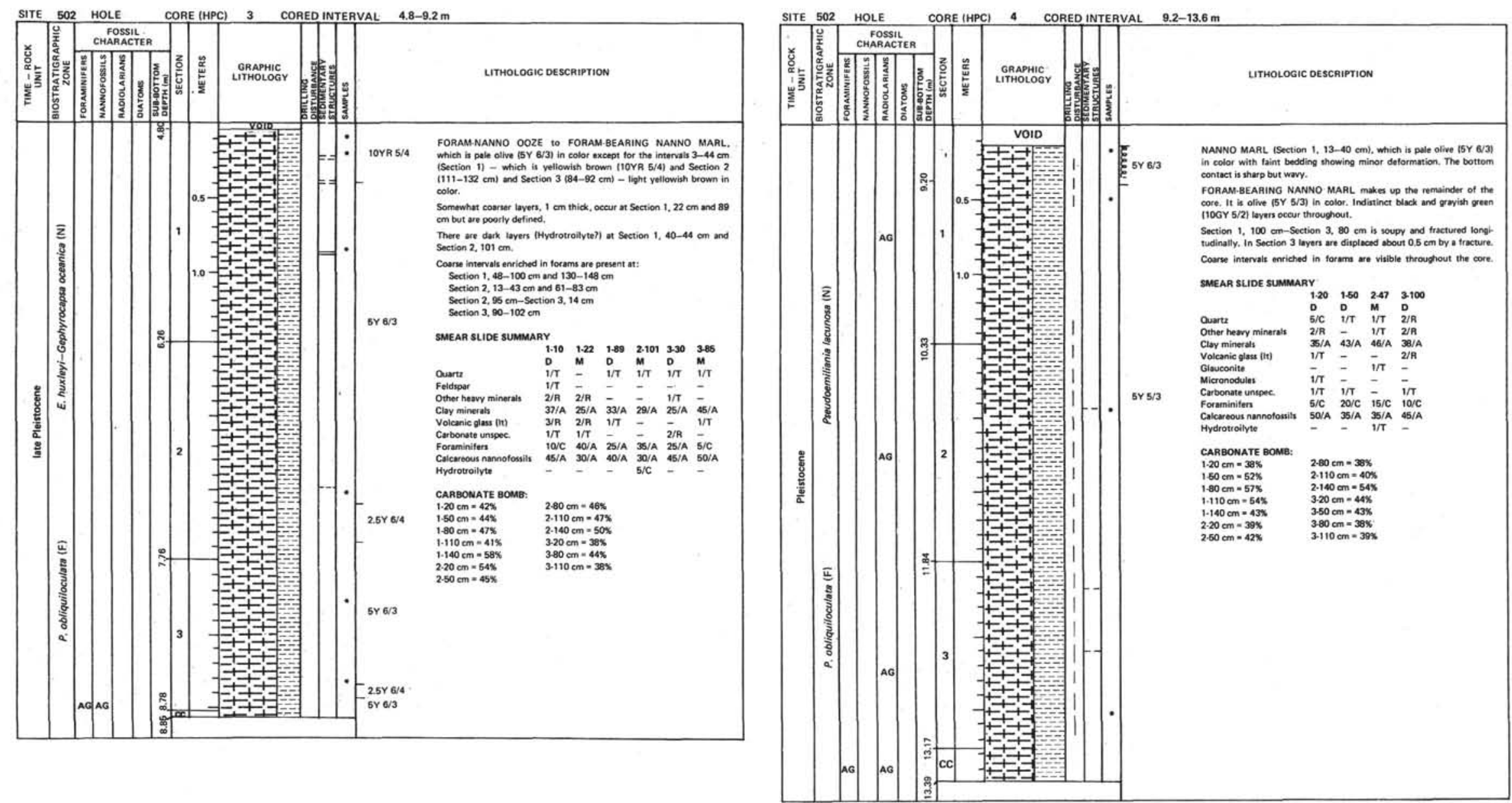

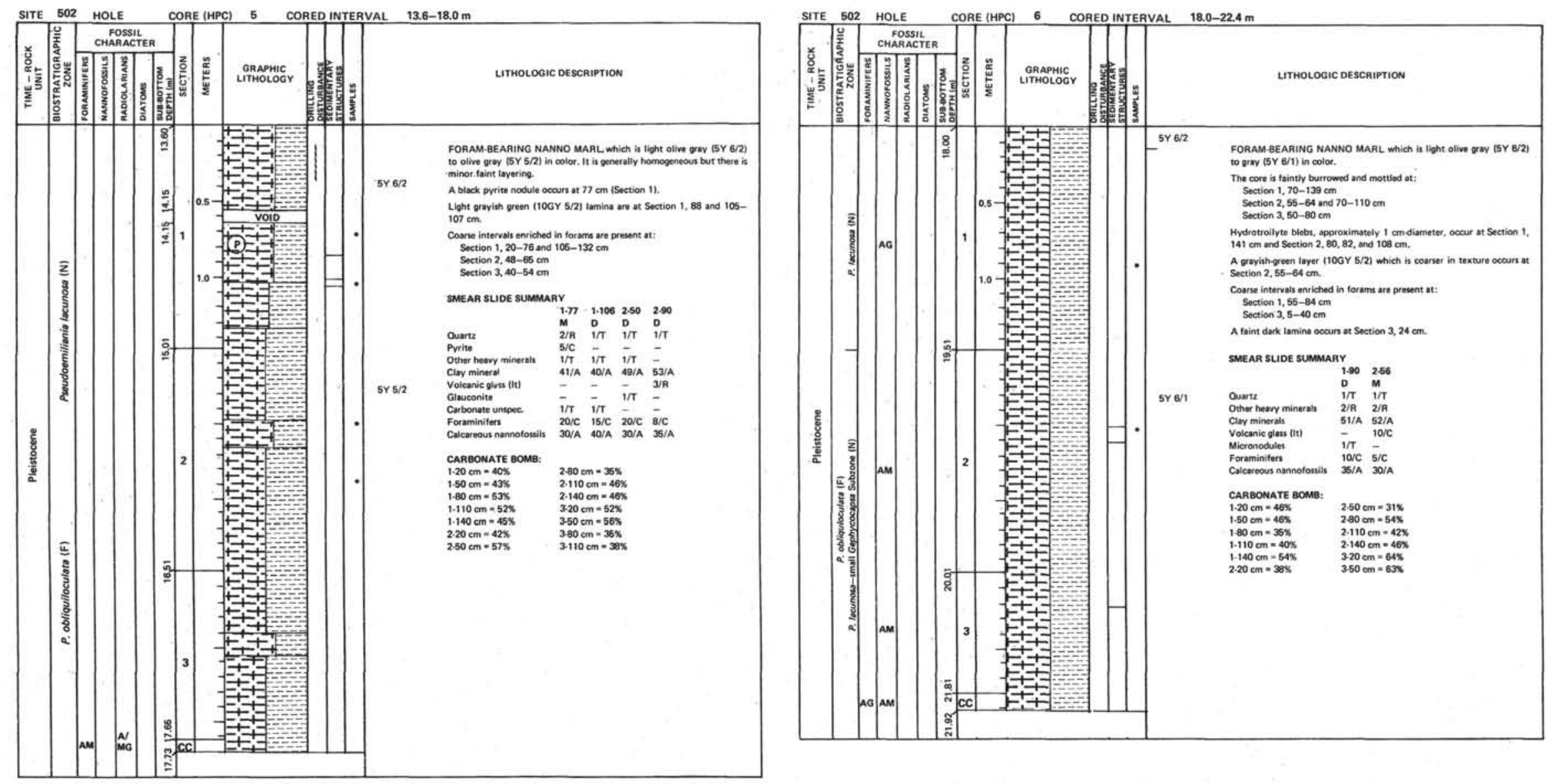

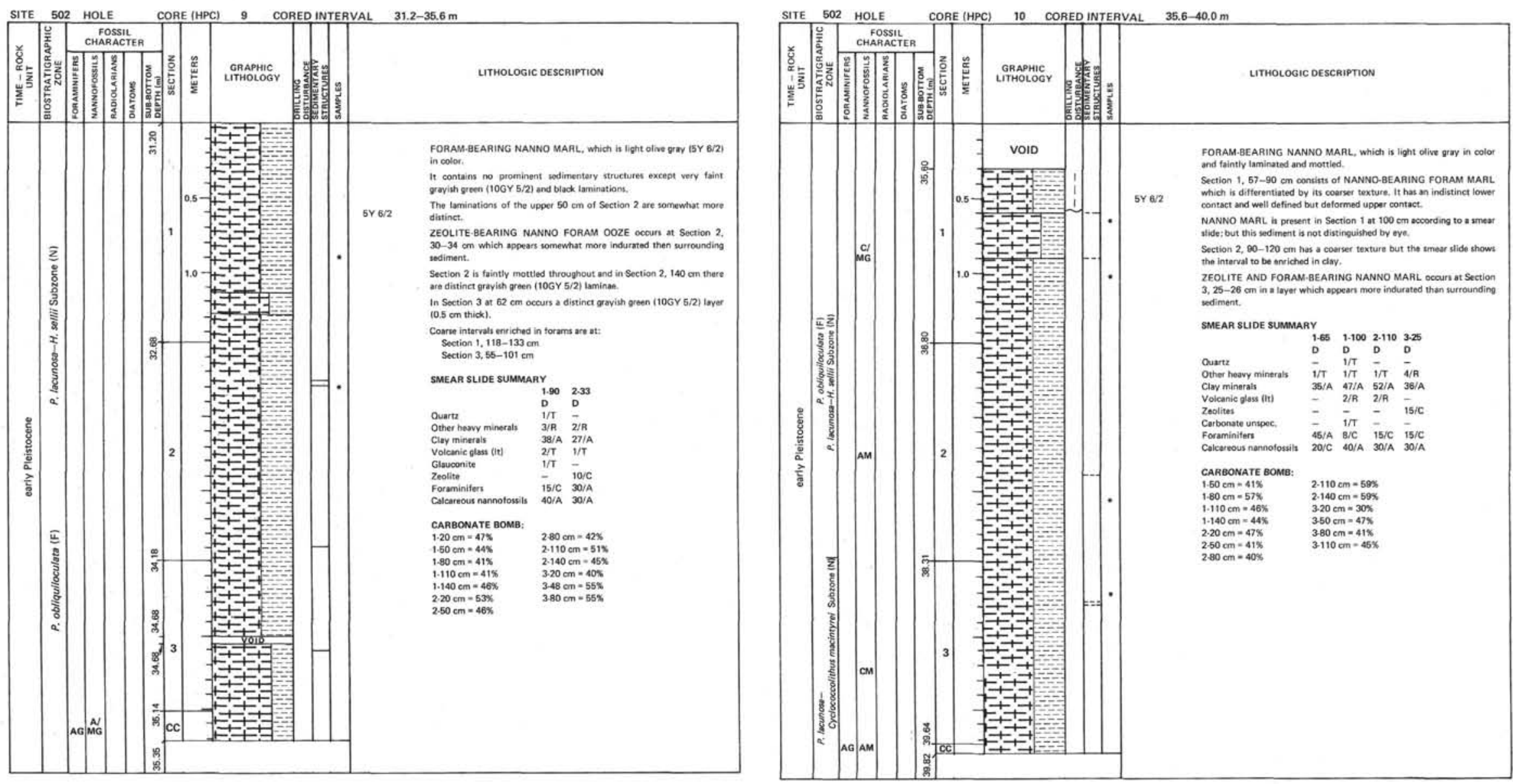


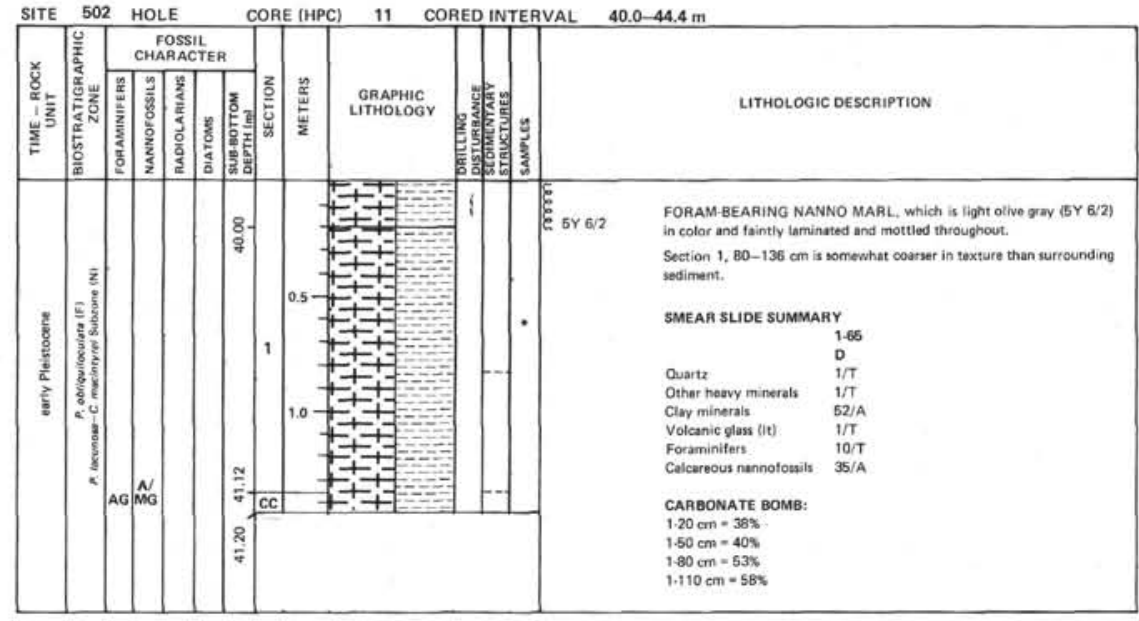

SITE 502 HOLE CORE (HPC) 12 CORED INTERVAL $44.4-48.8 \mathrm{~m}$

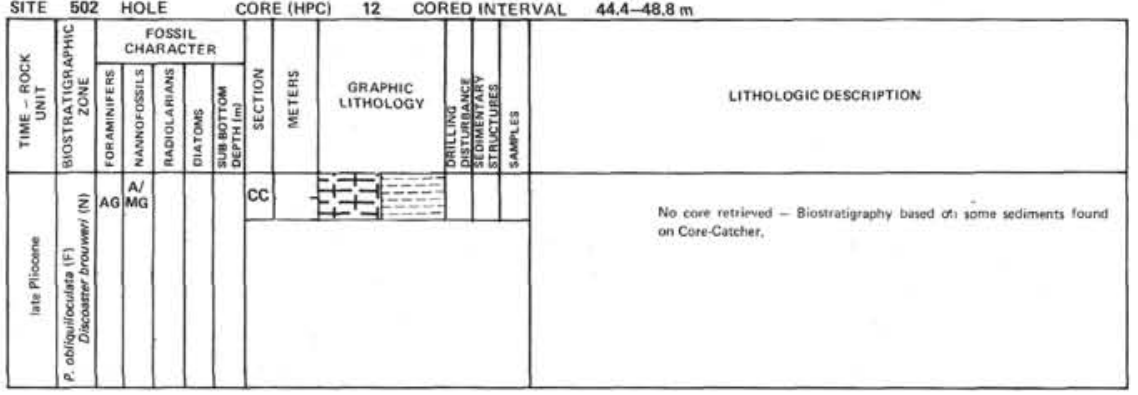

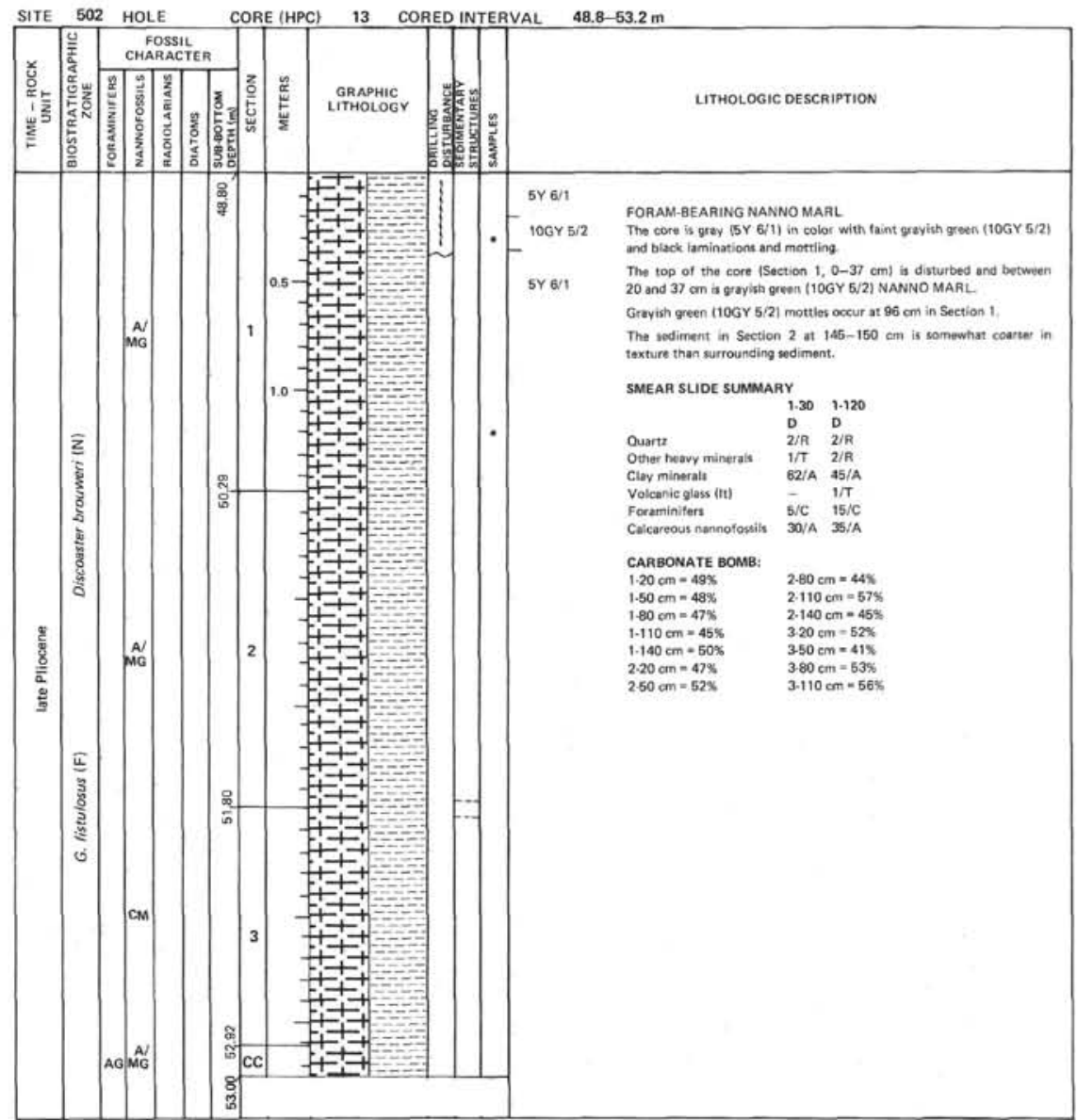



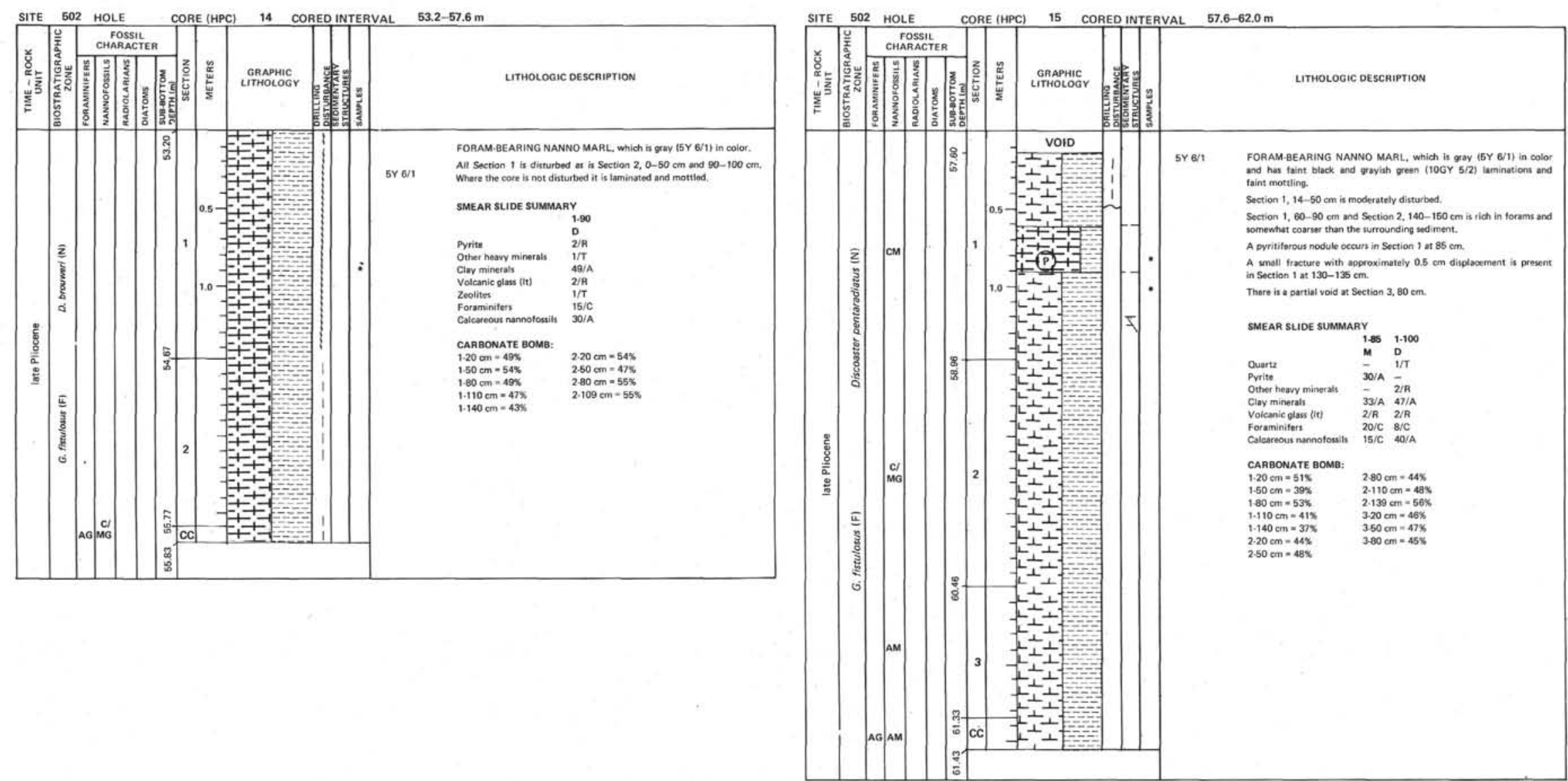


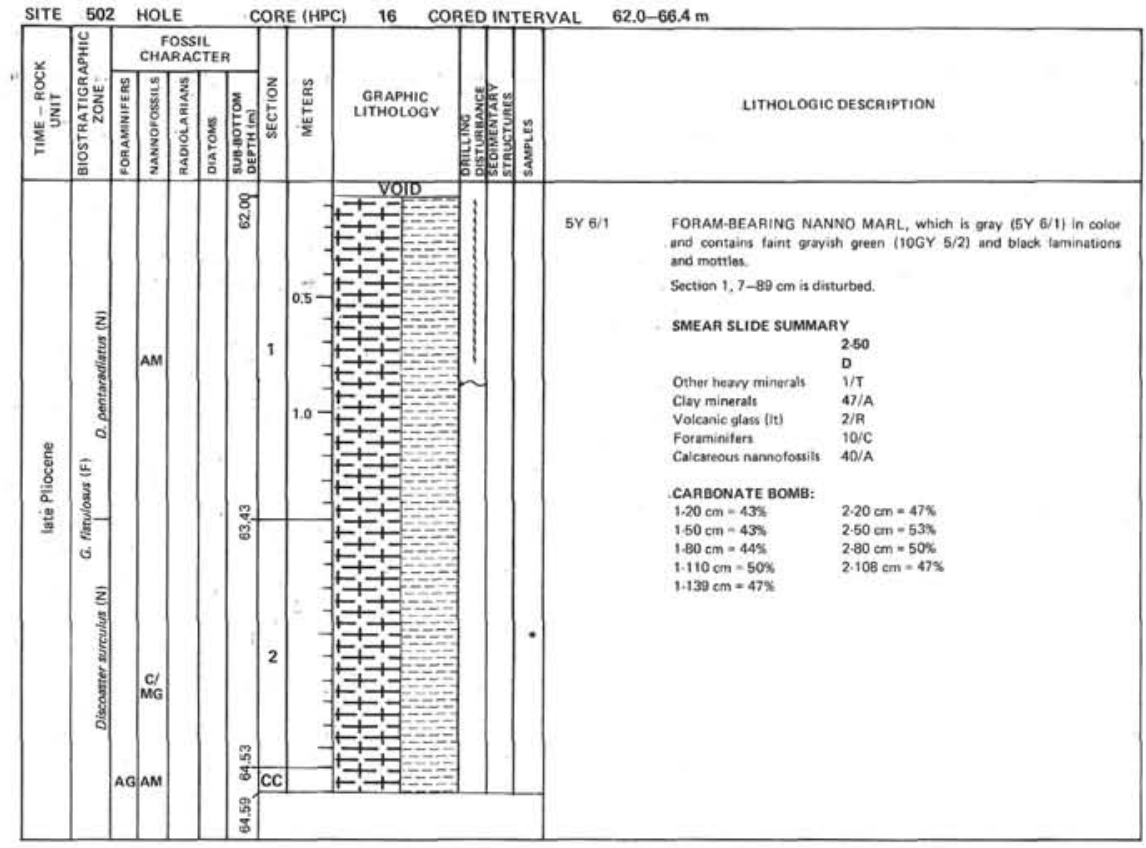

SITE 502 HOLE CORE IHPC) 17 CORED INTSERVAL 66.4-70.8 m

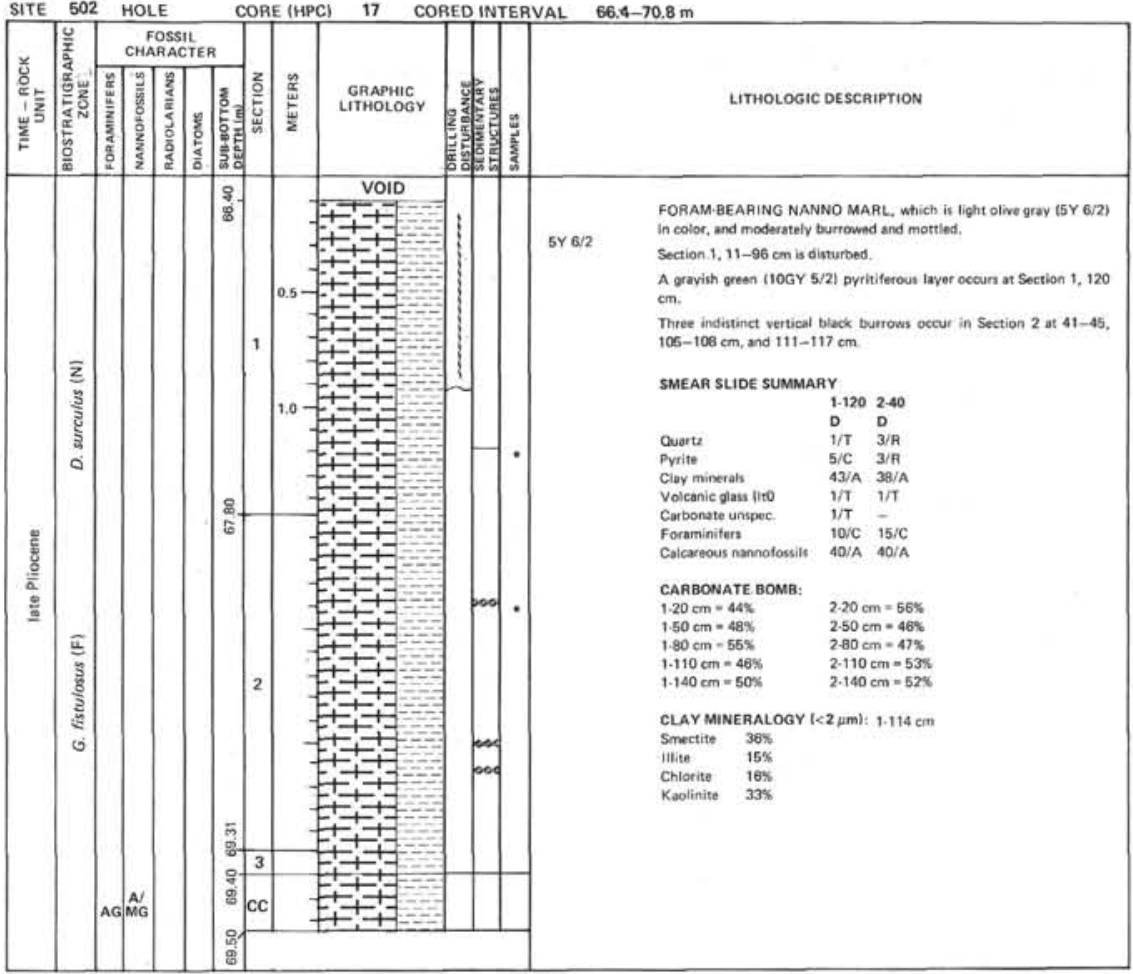

SITE 502 HOLE CORE (HPC) 18 CORED INTERVAL $70.8-75.2 \mathrm{~m}$

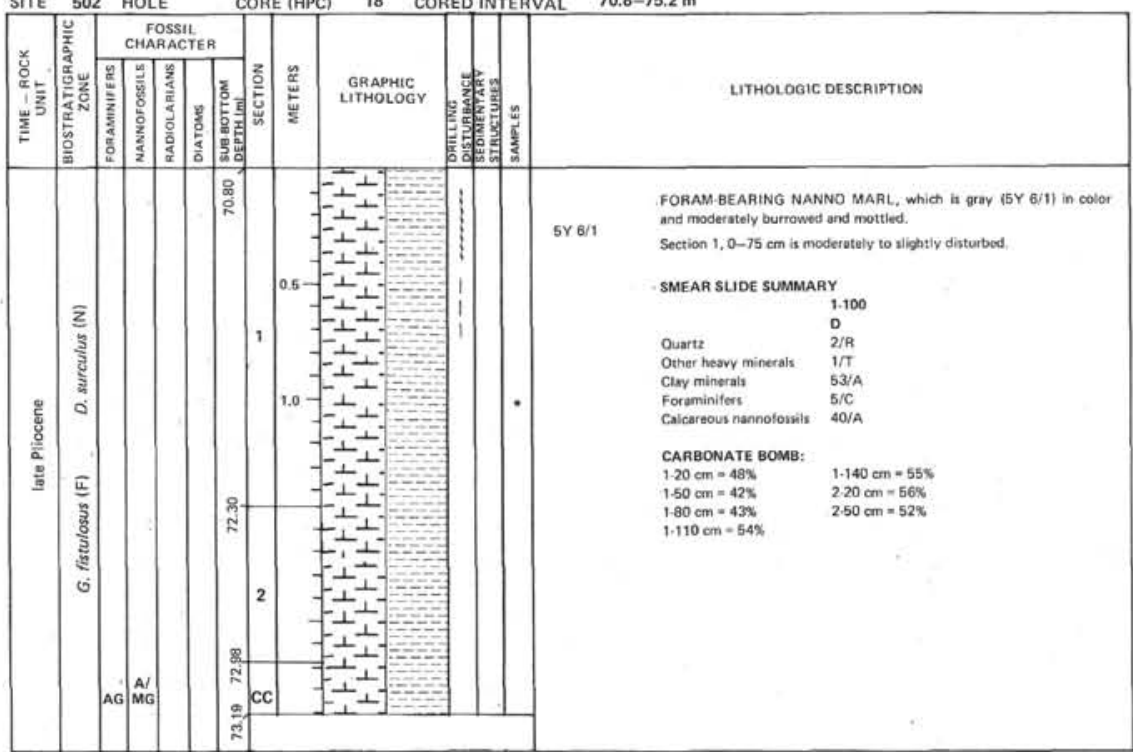



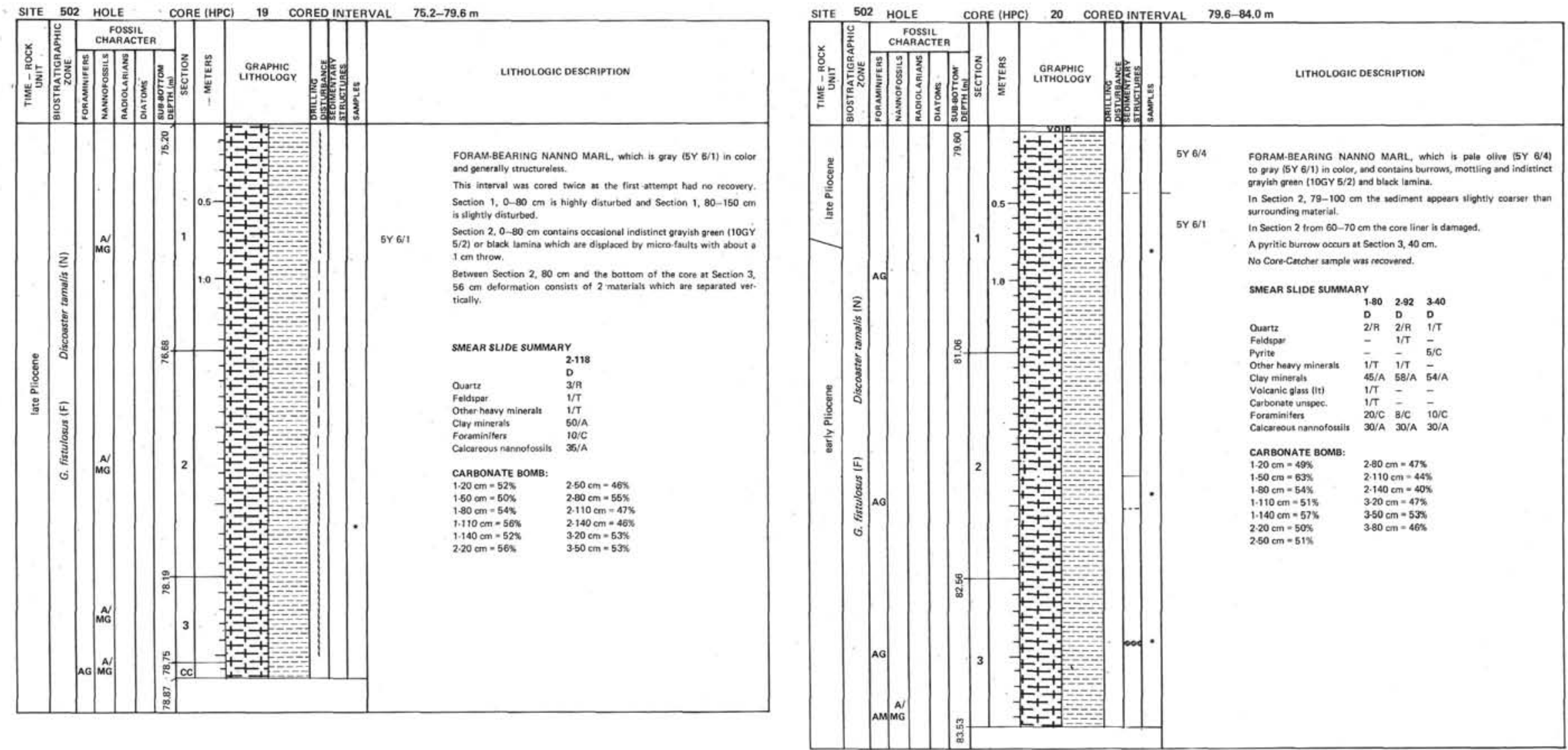


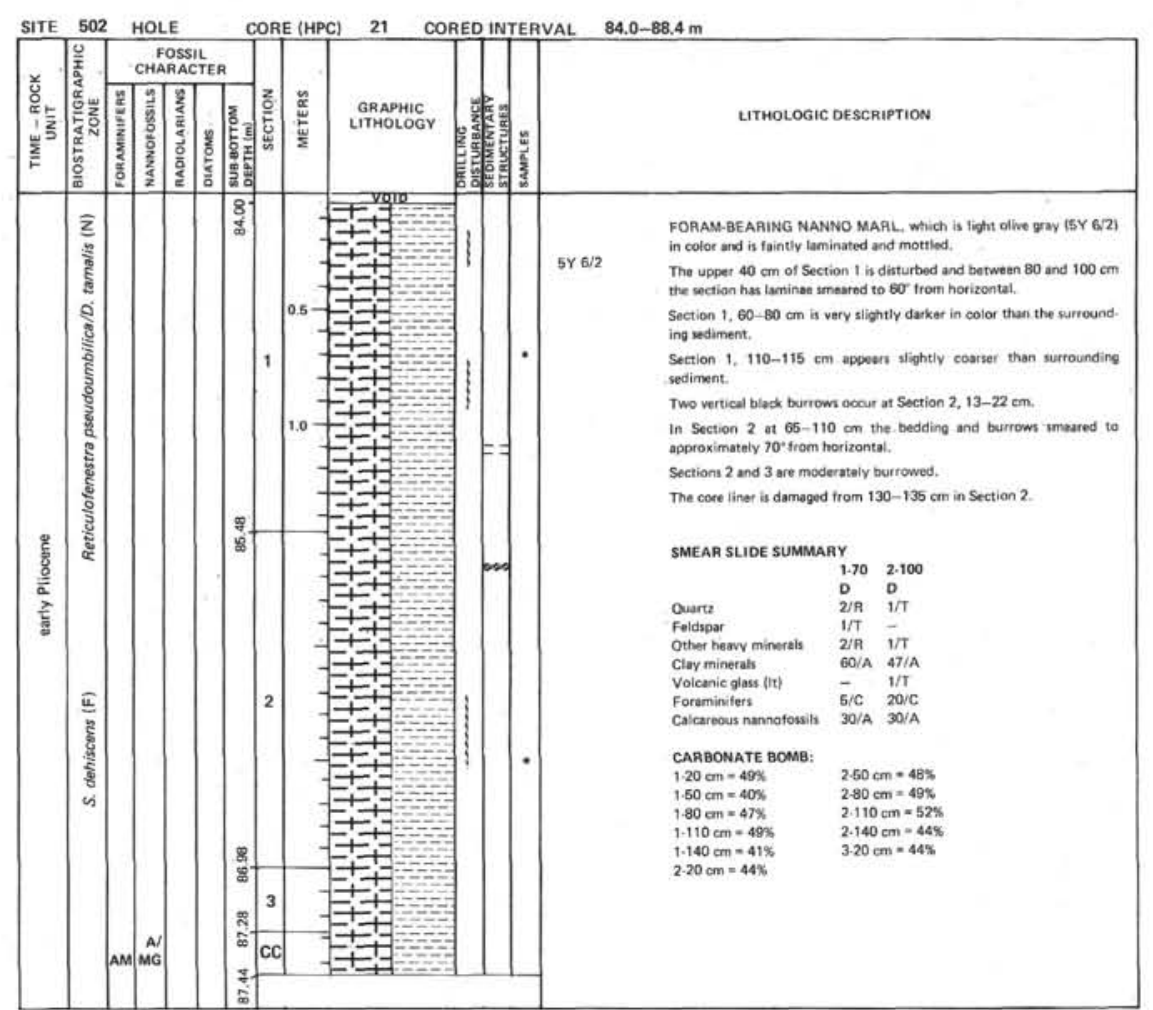

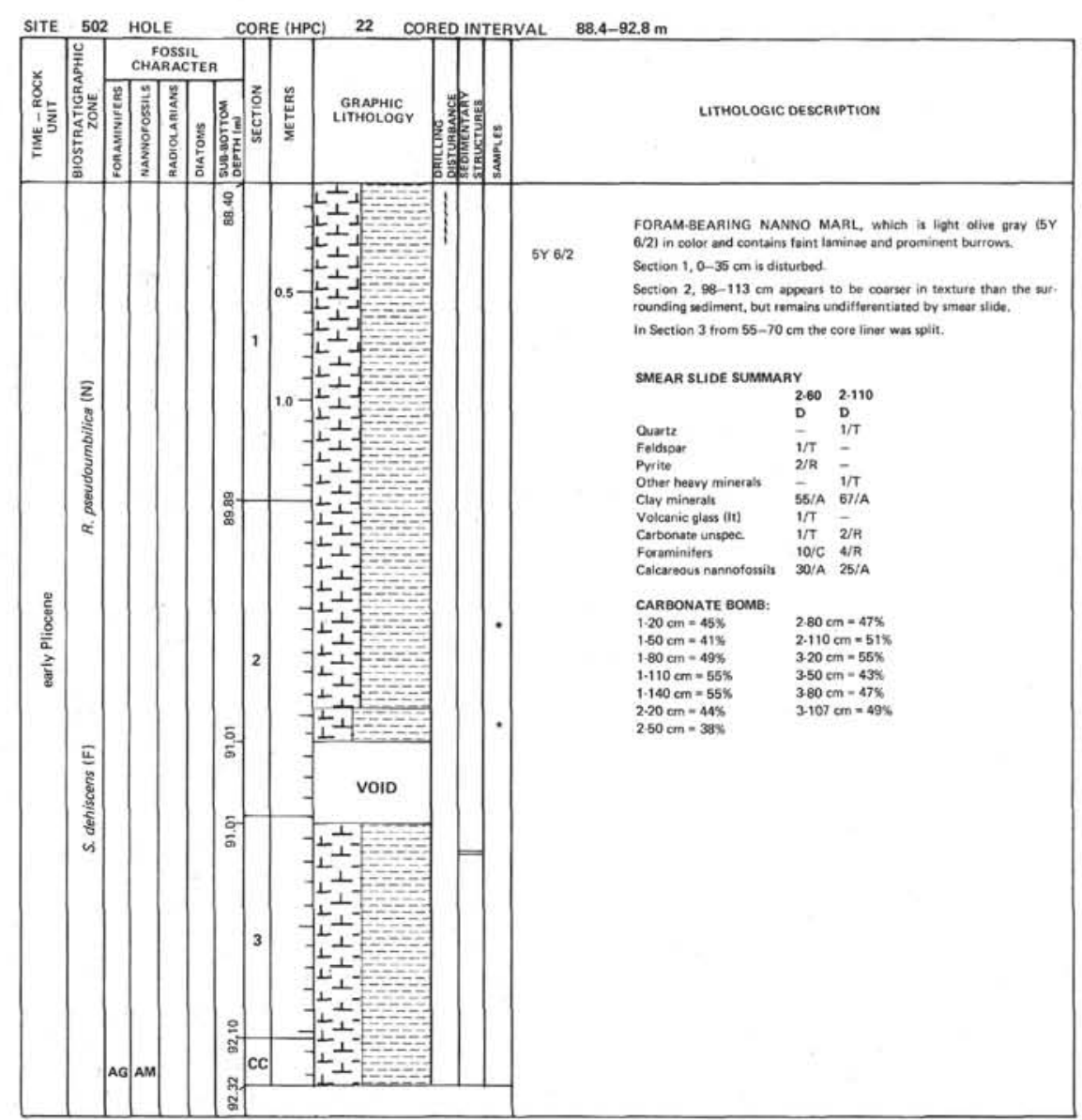



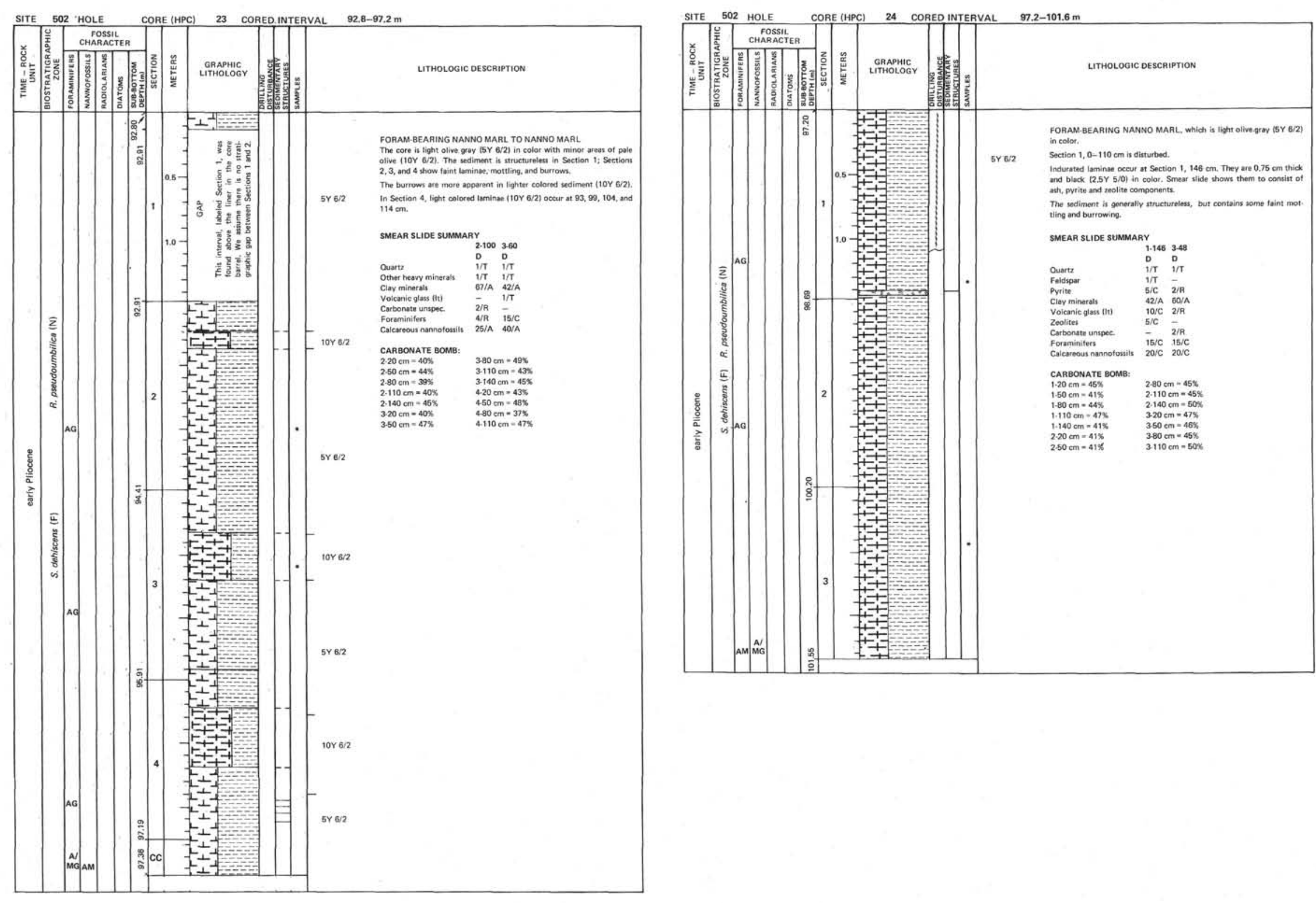

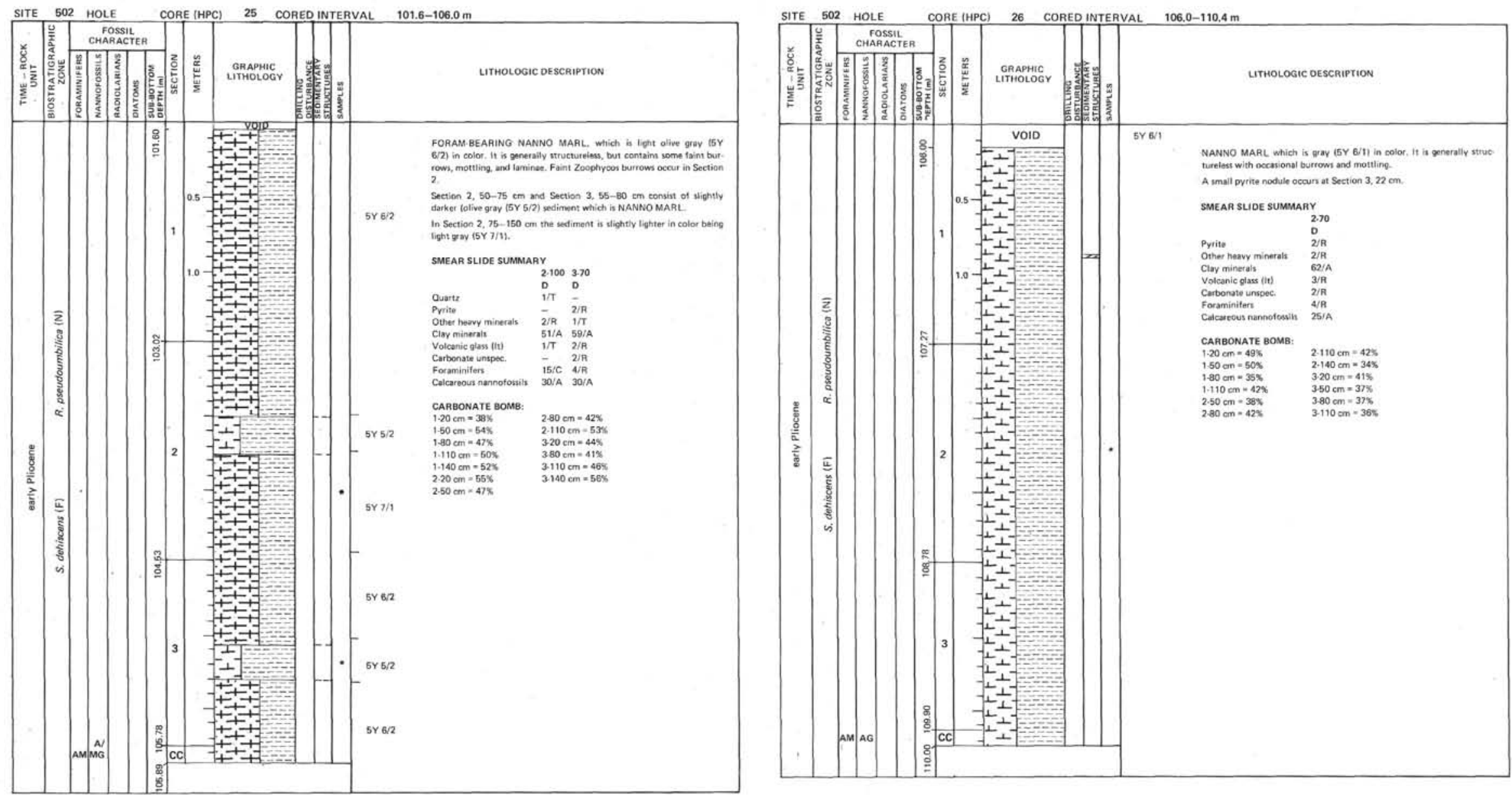

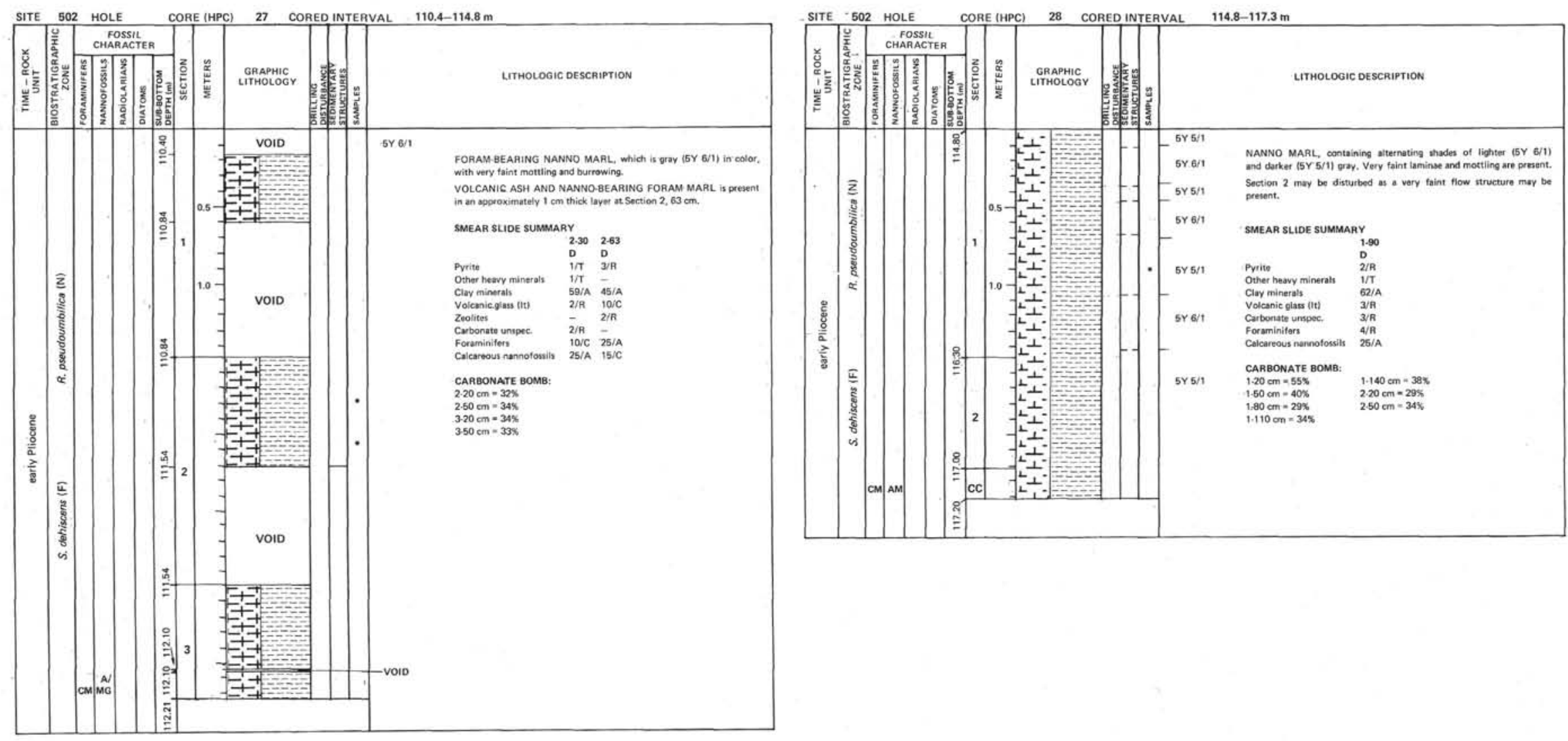

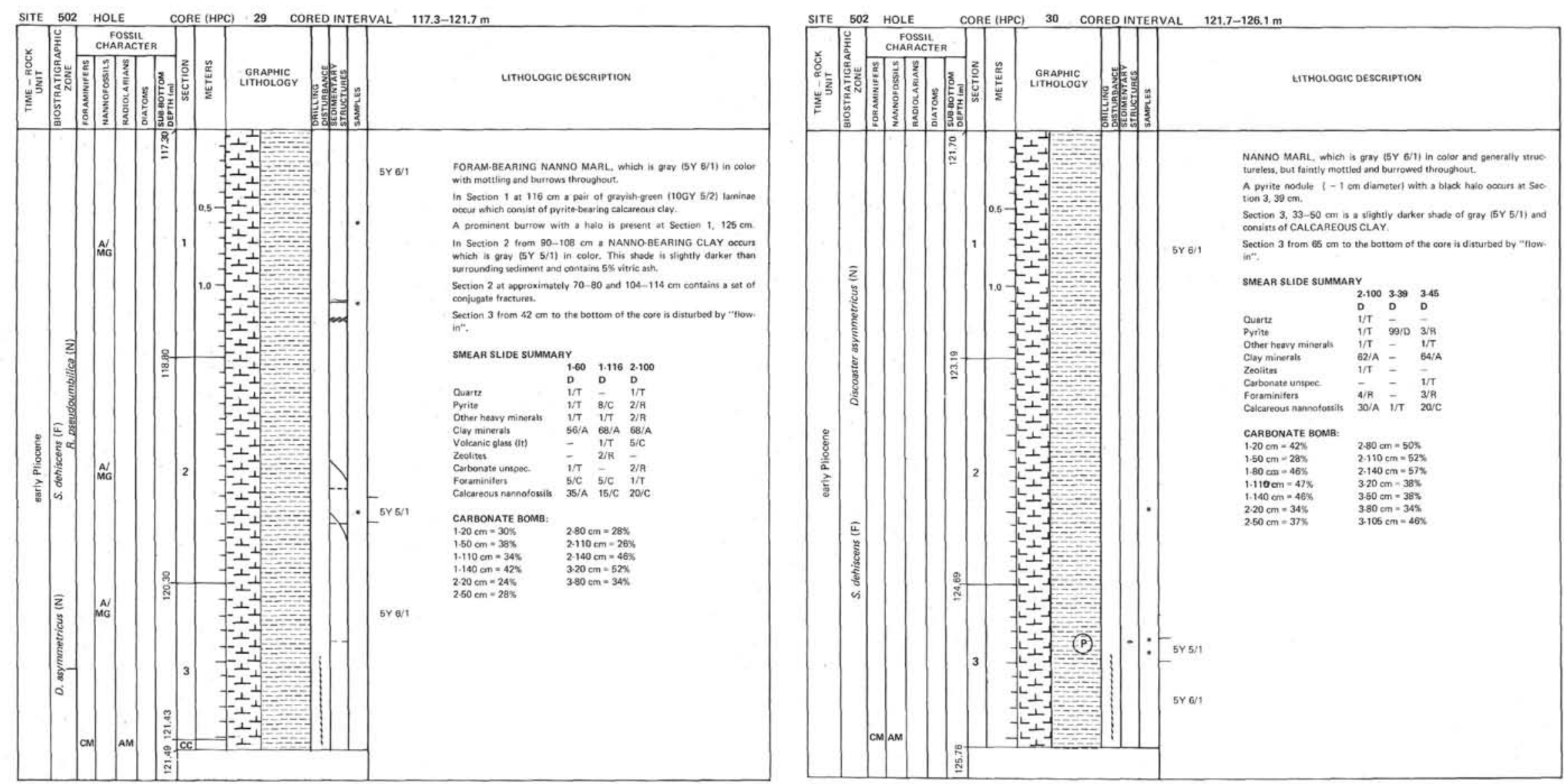

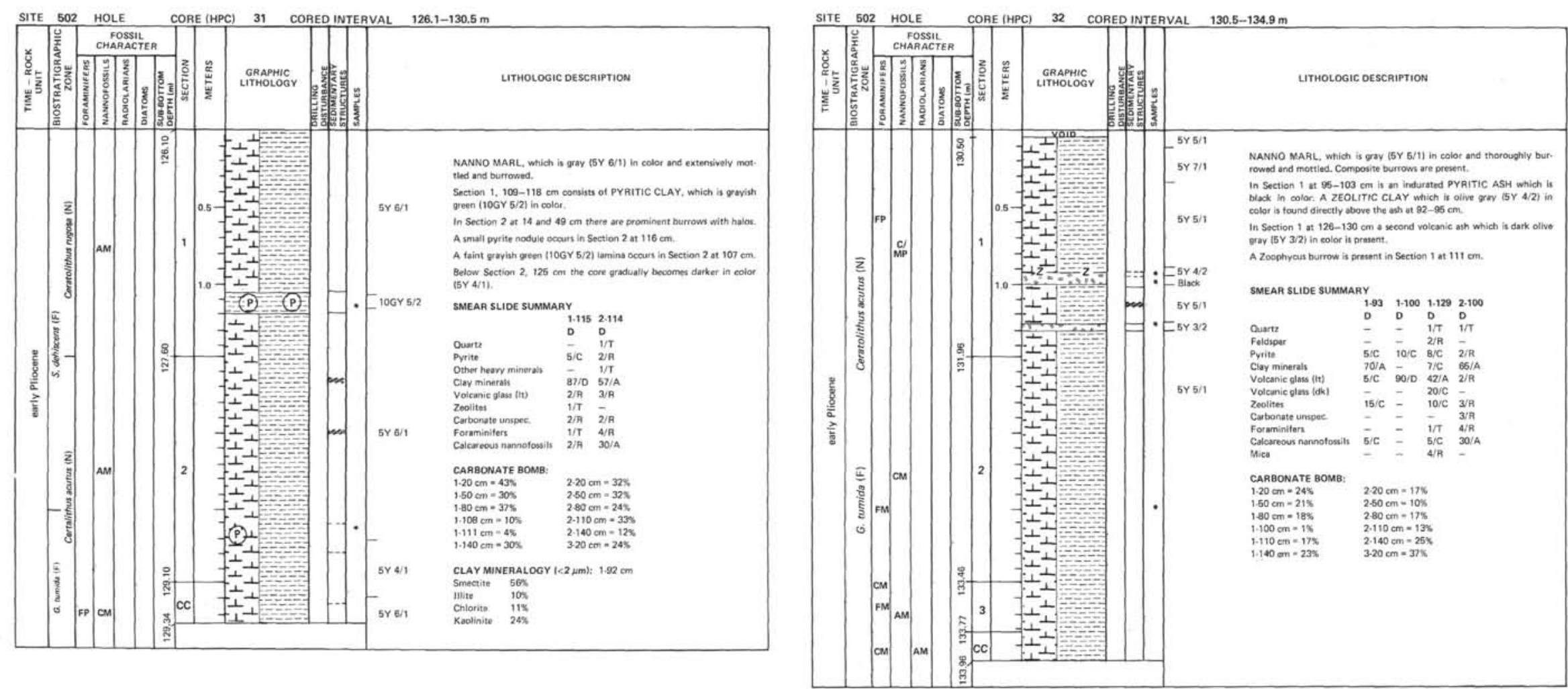

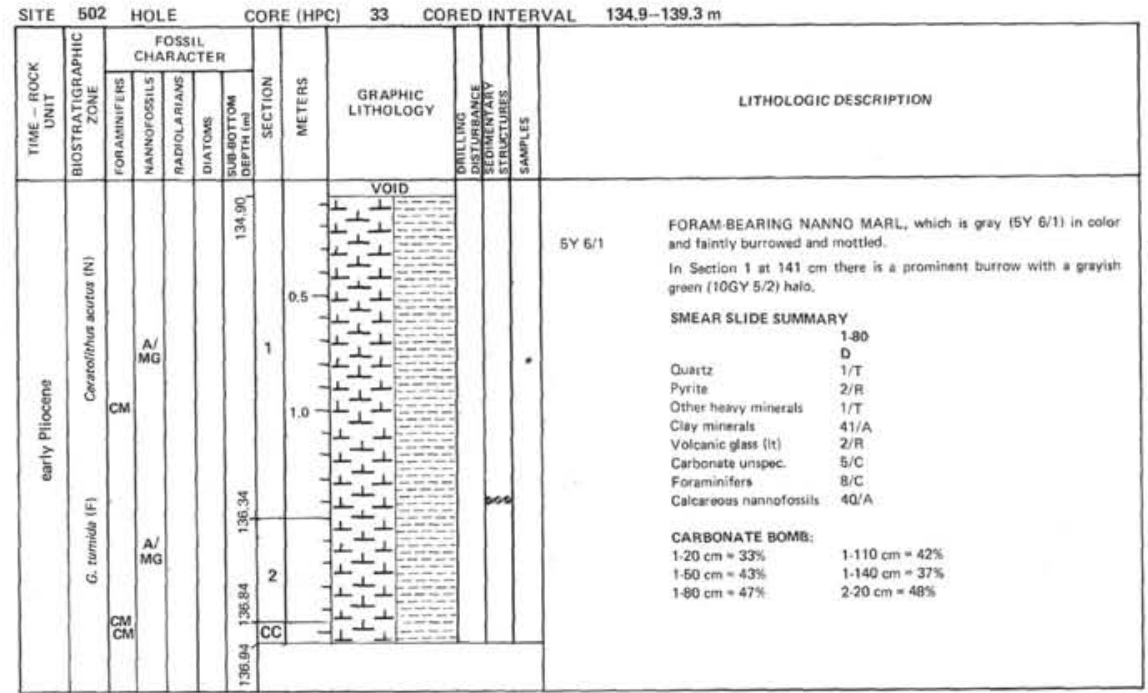



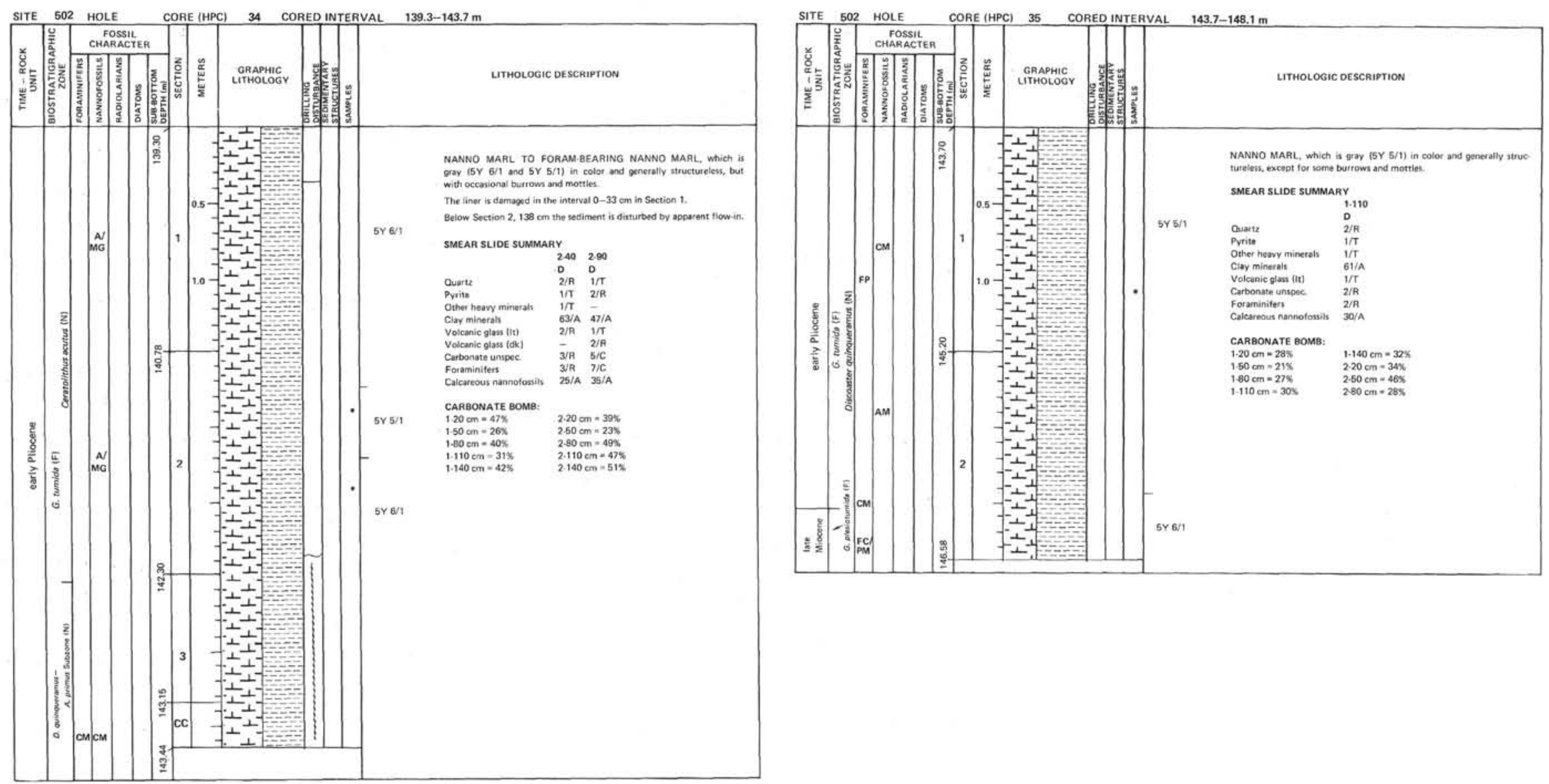

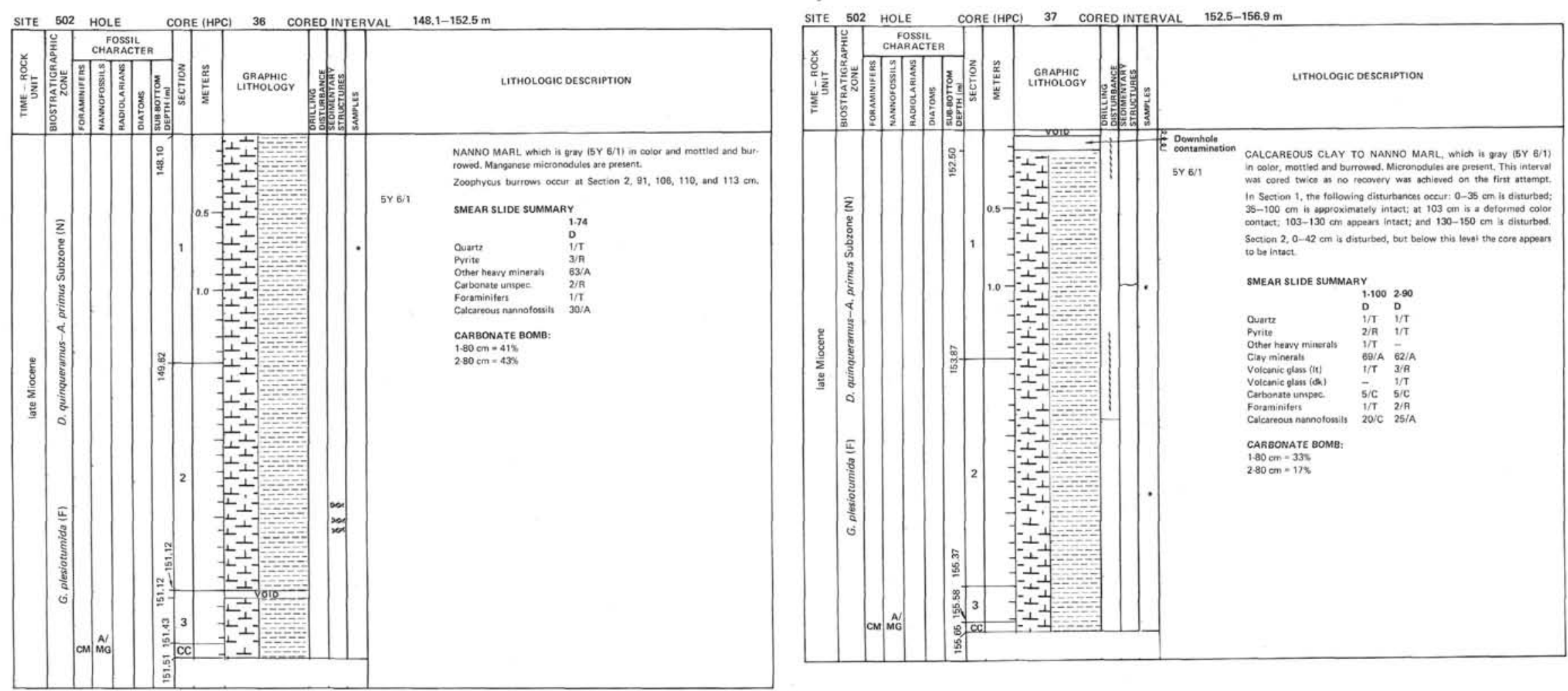

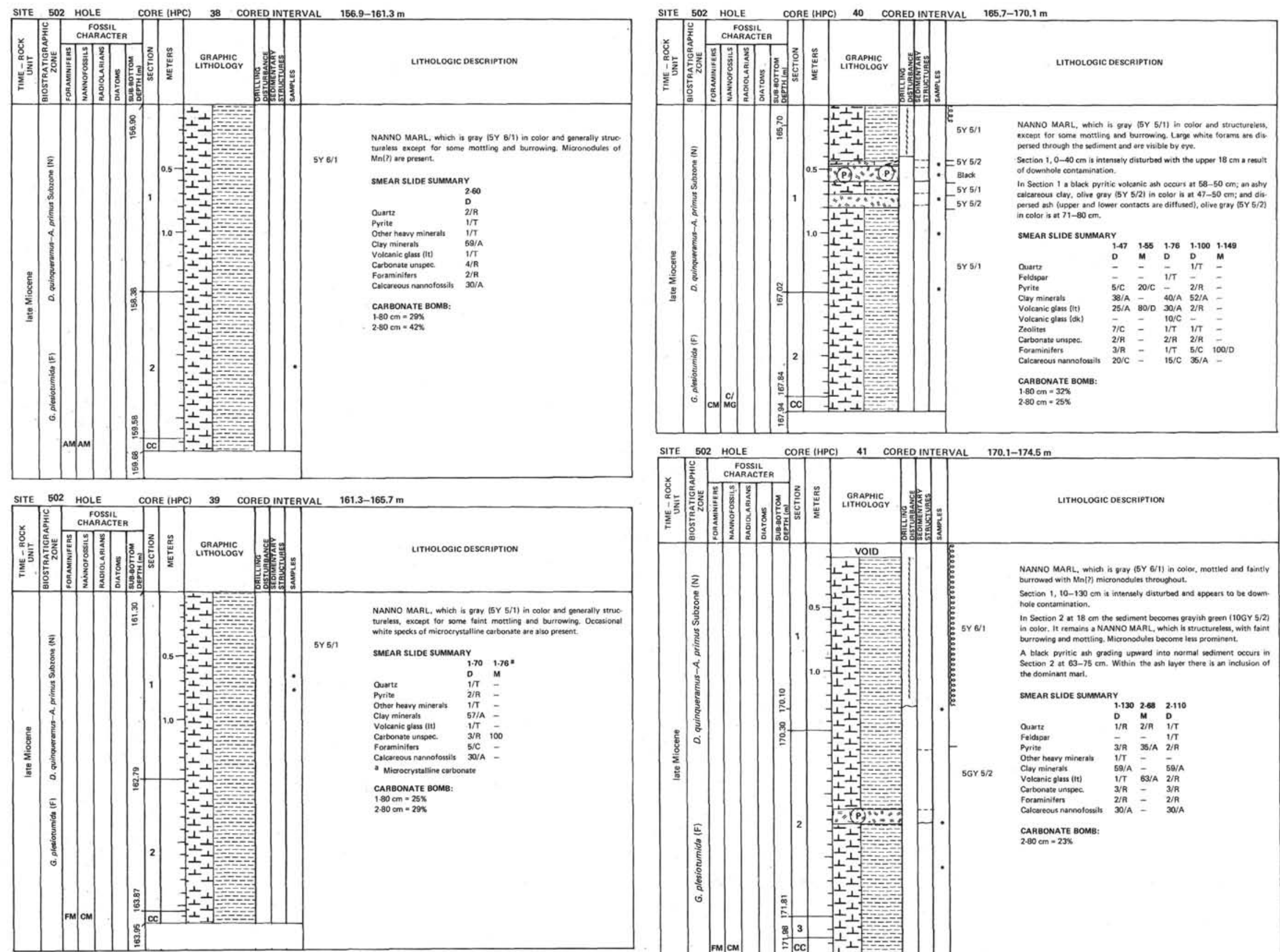

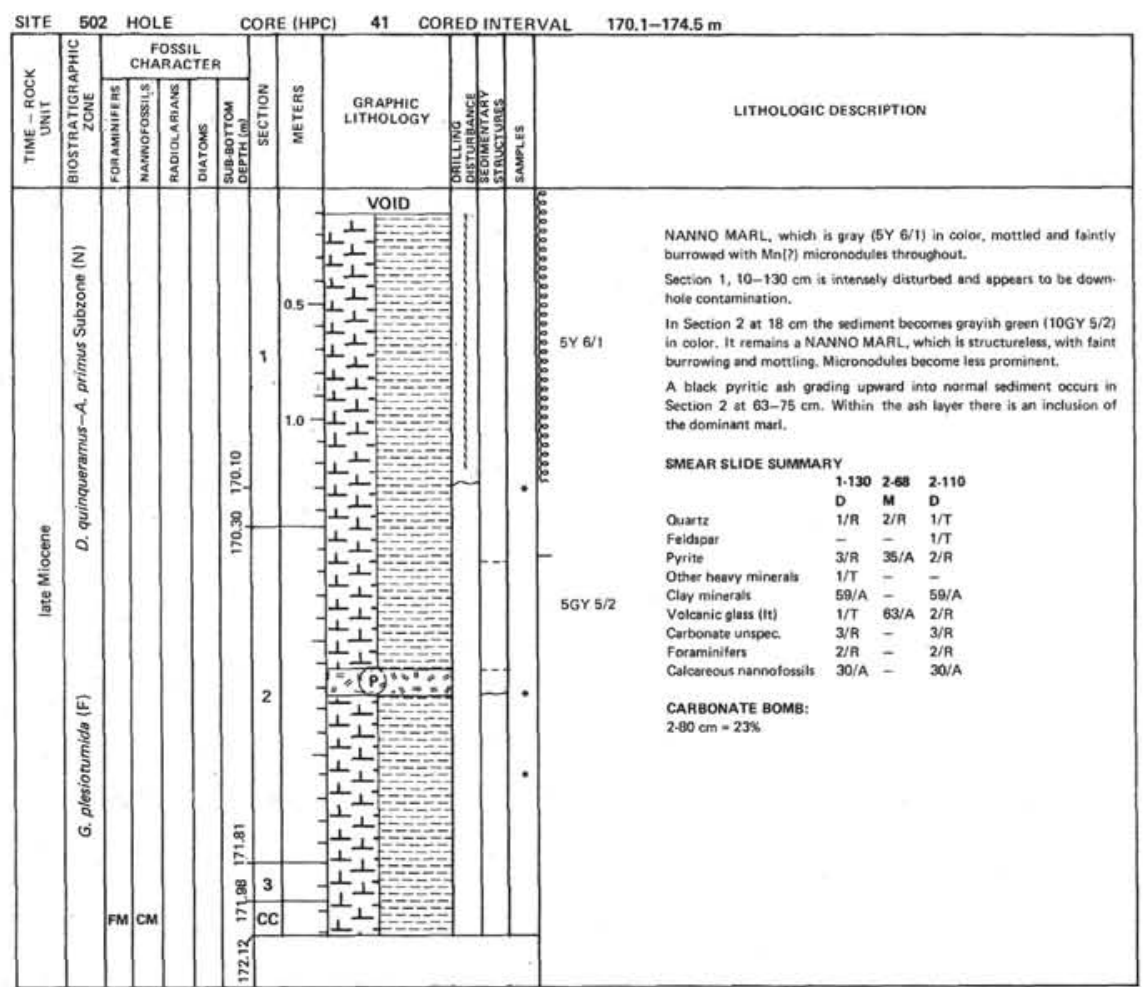




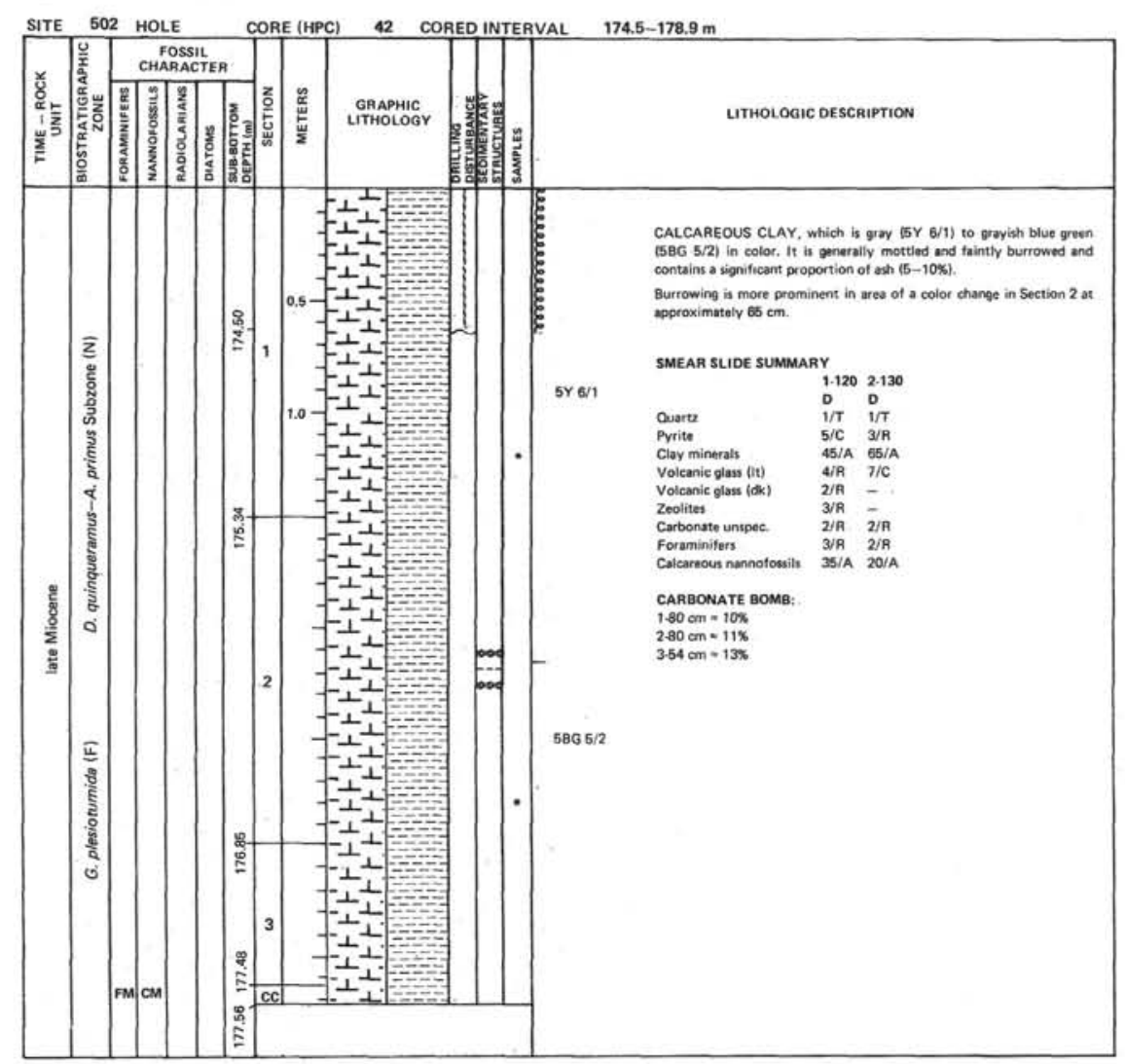

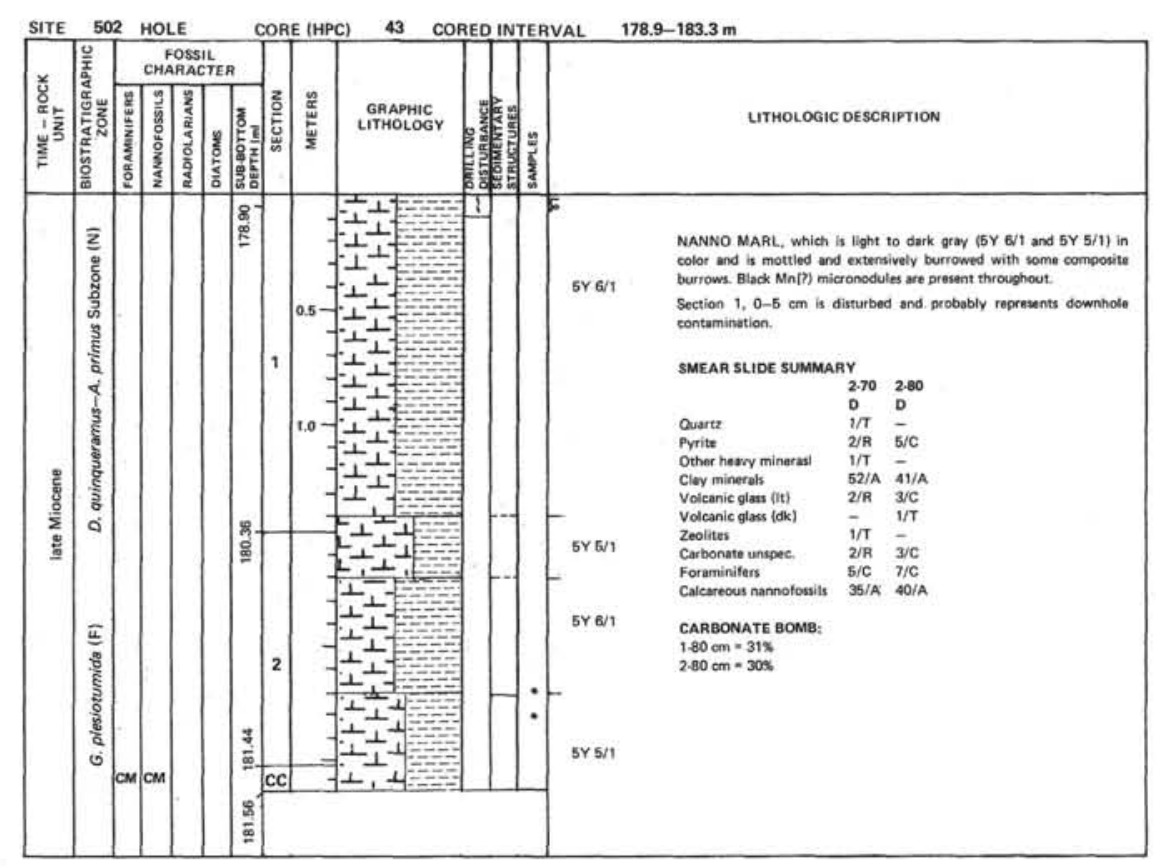

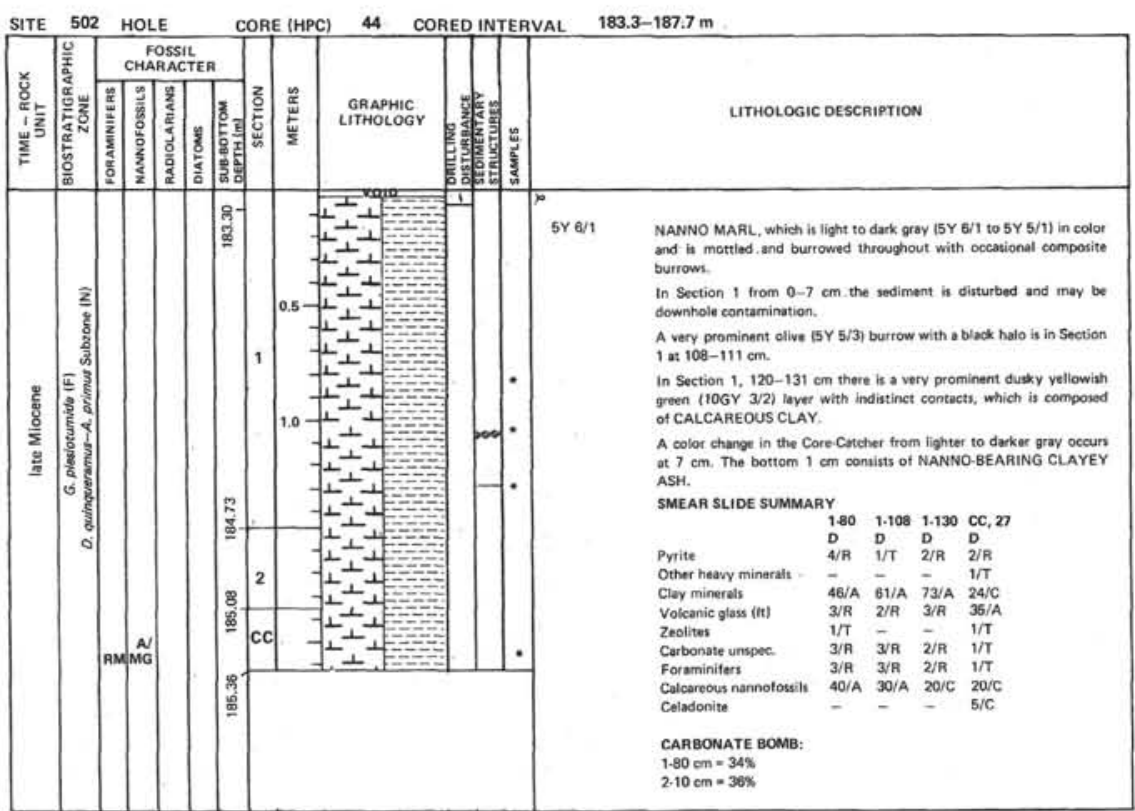



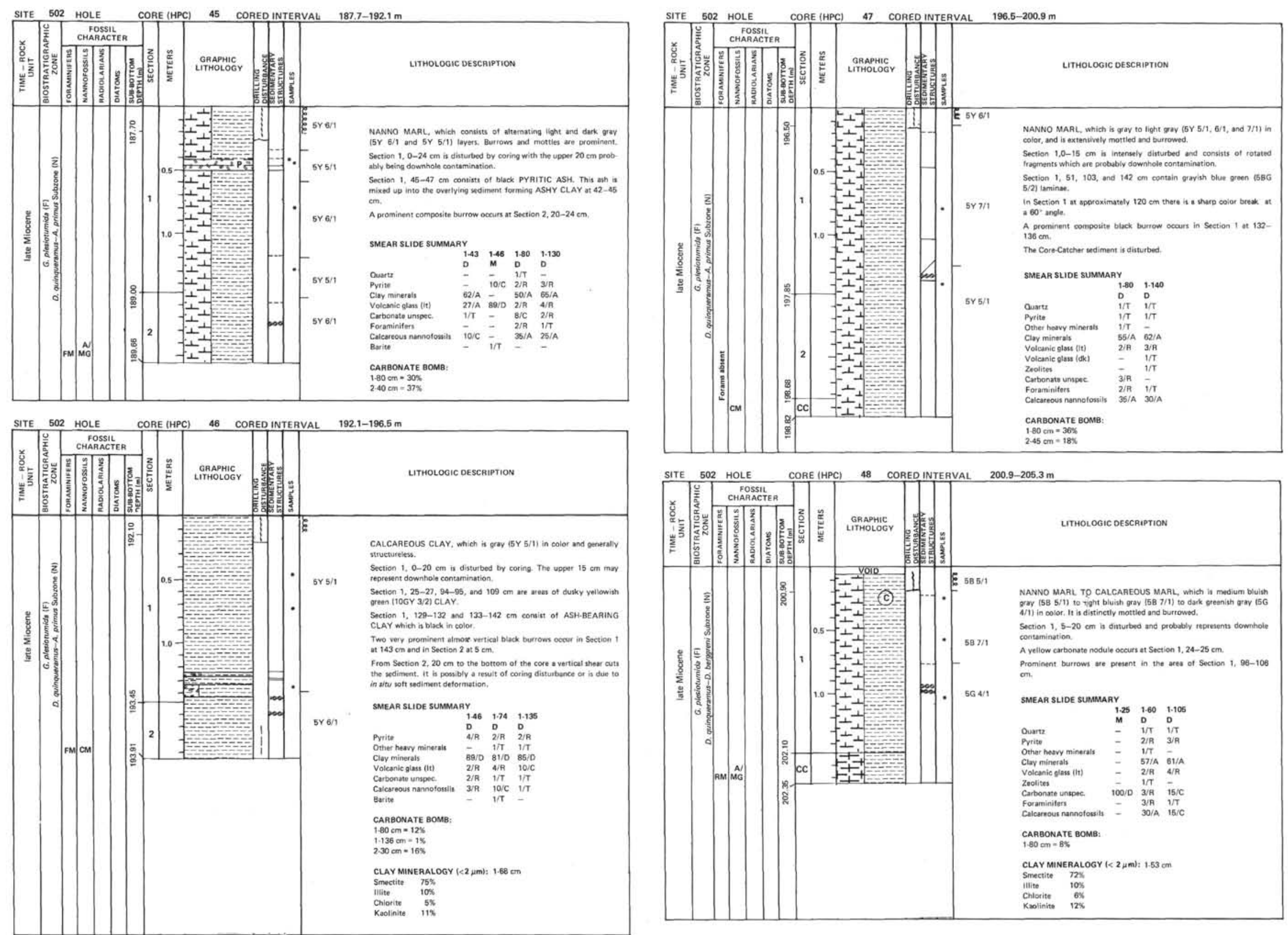


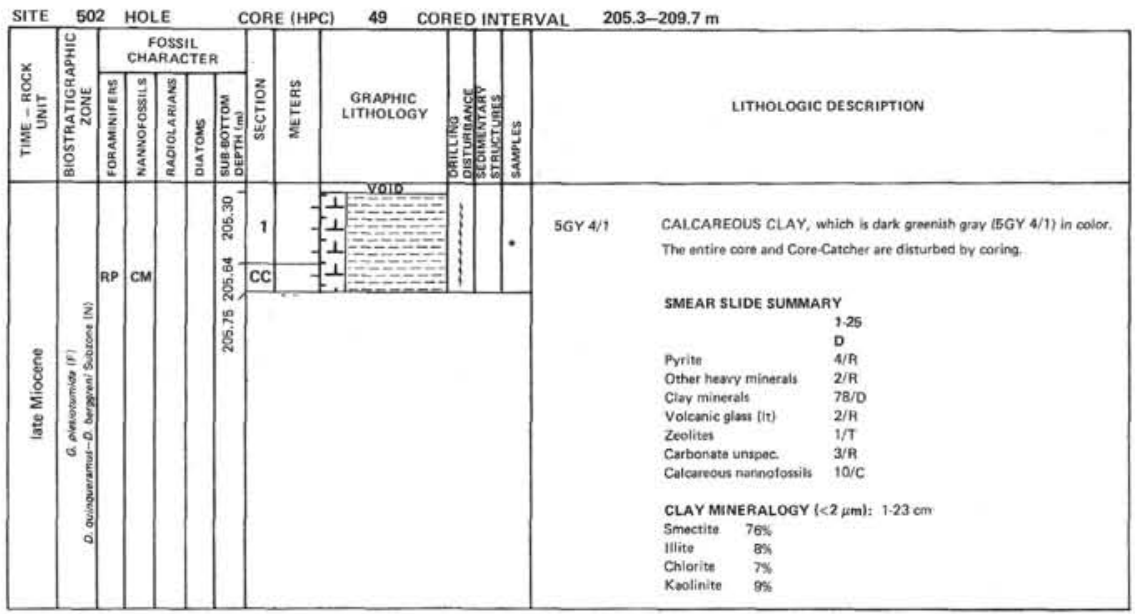

SITE 502 HOLE CORE (HPC) 50 CORED INTERVAL 209.7-214.1 m

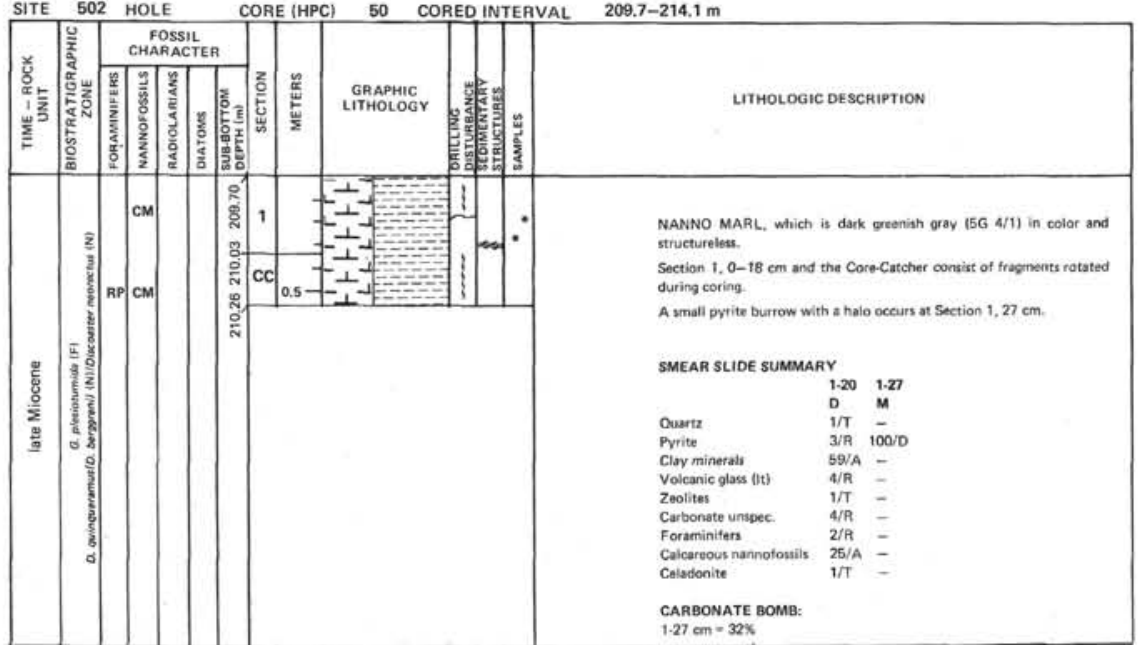

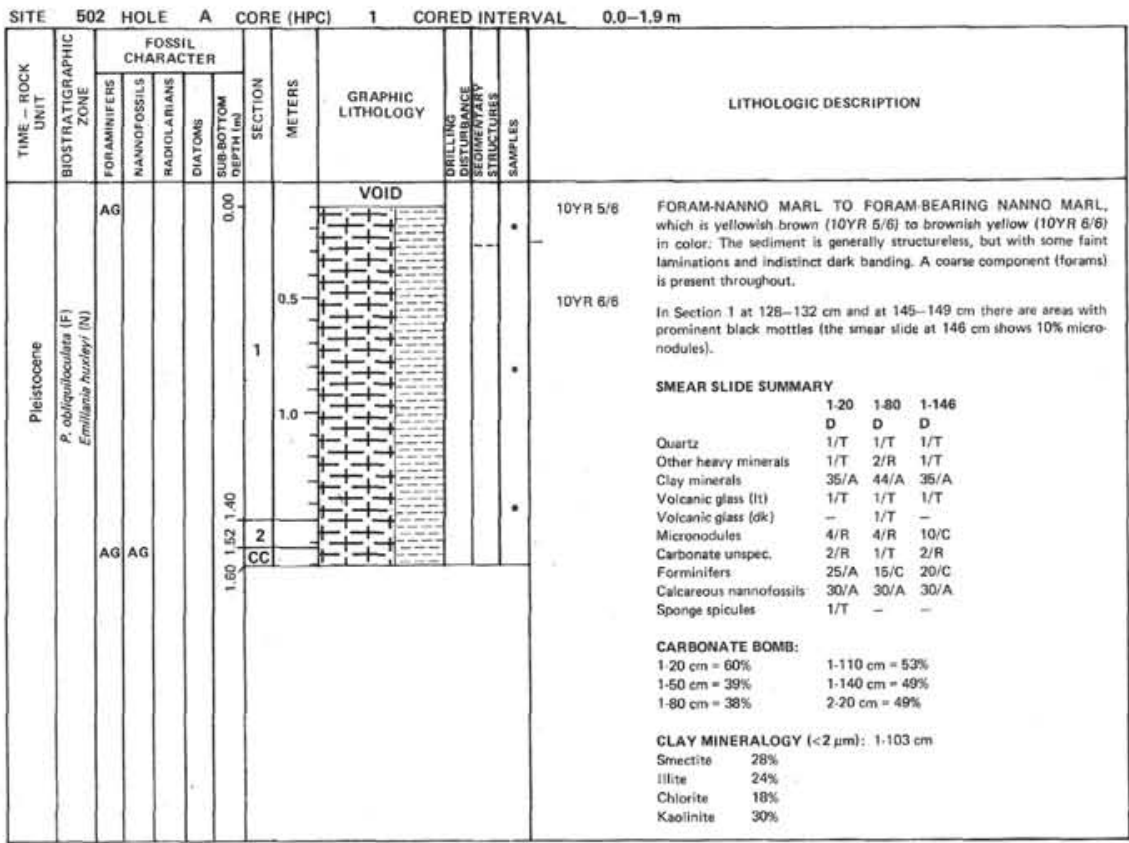



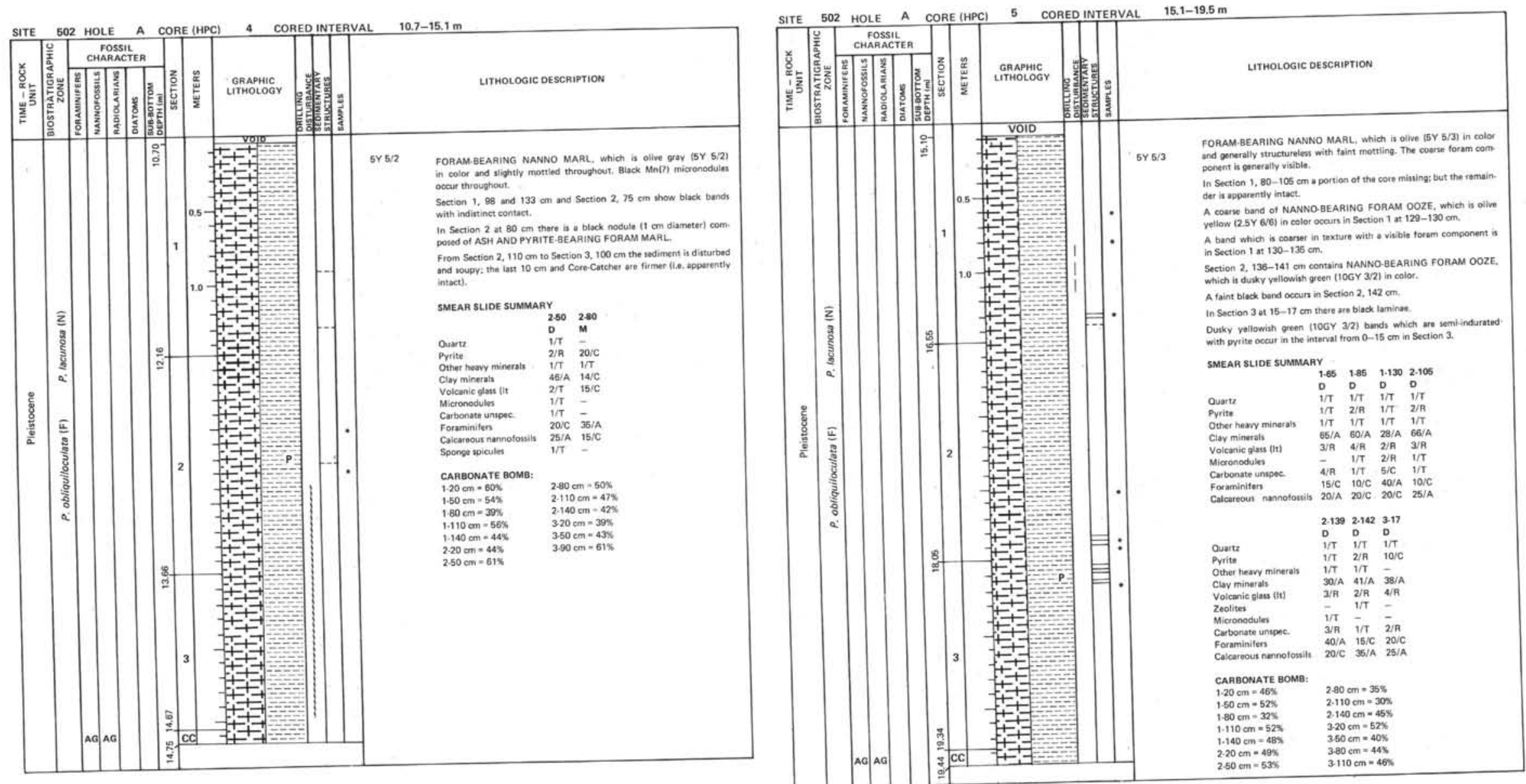

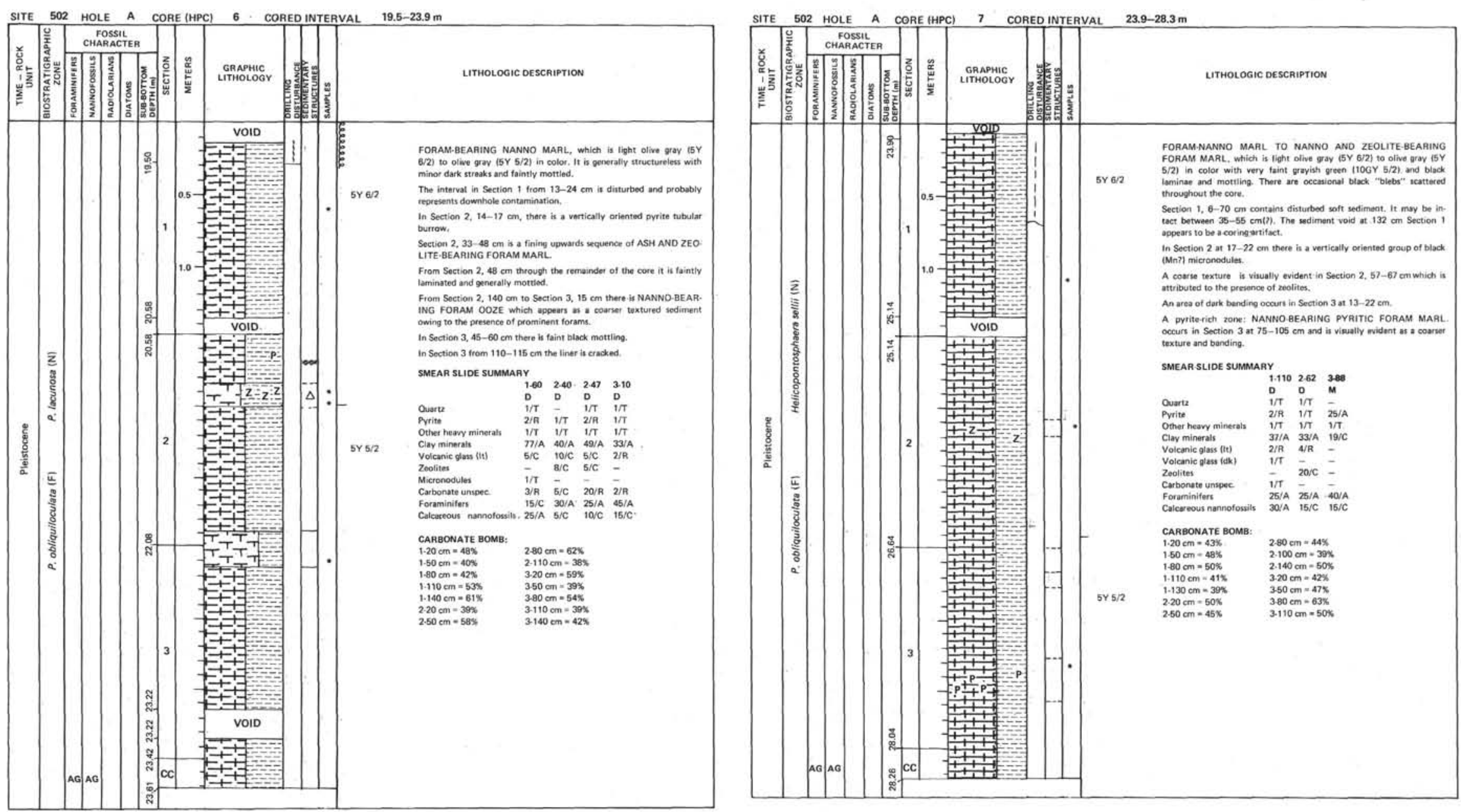


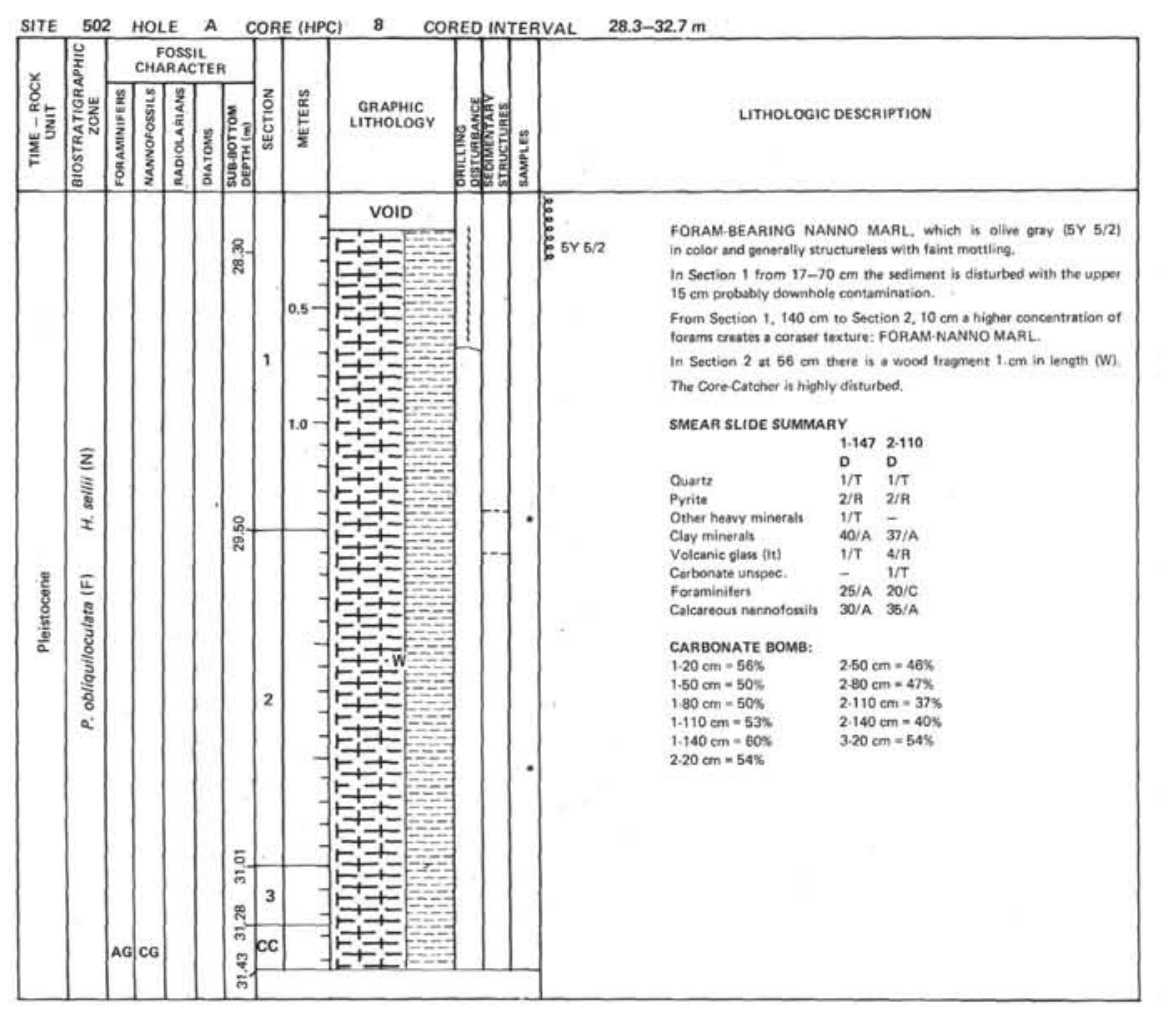

SITE 502 HOLE A CORE (HPC) 9 CORED INTERVAL $32.7-37.1 \mathrm{~m}$

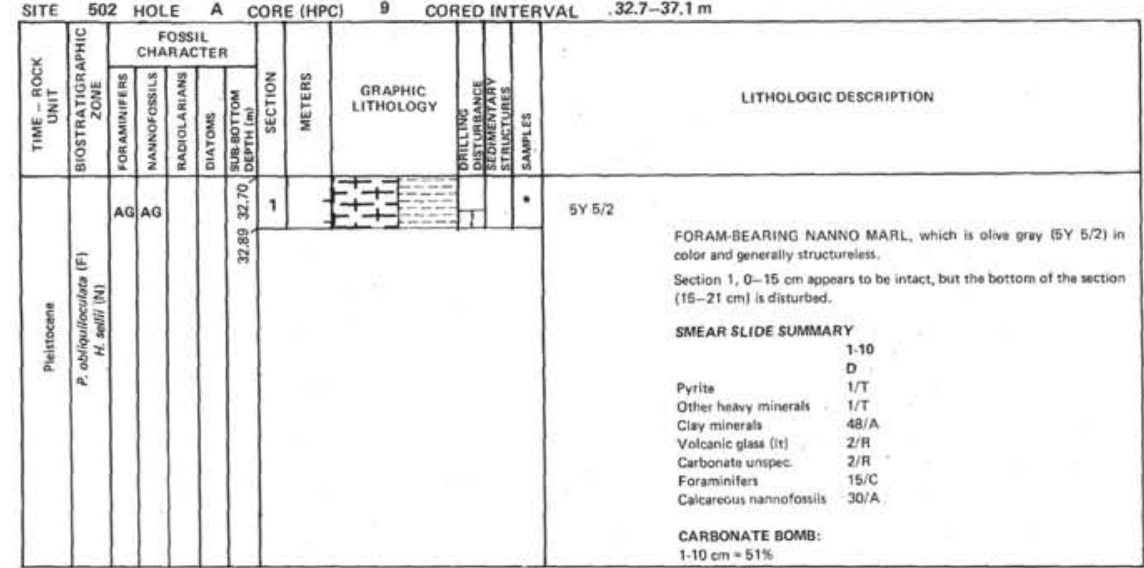

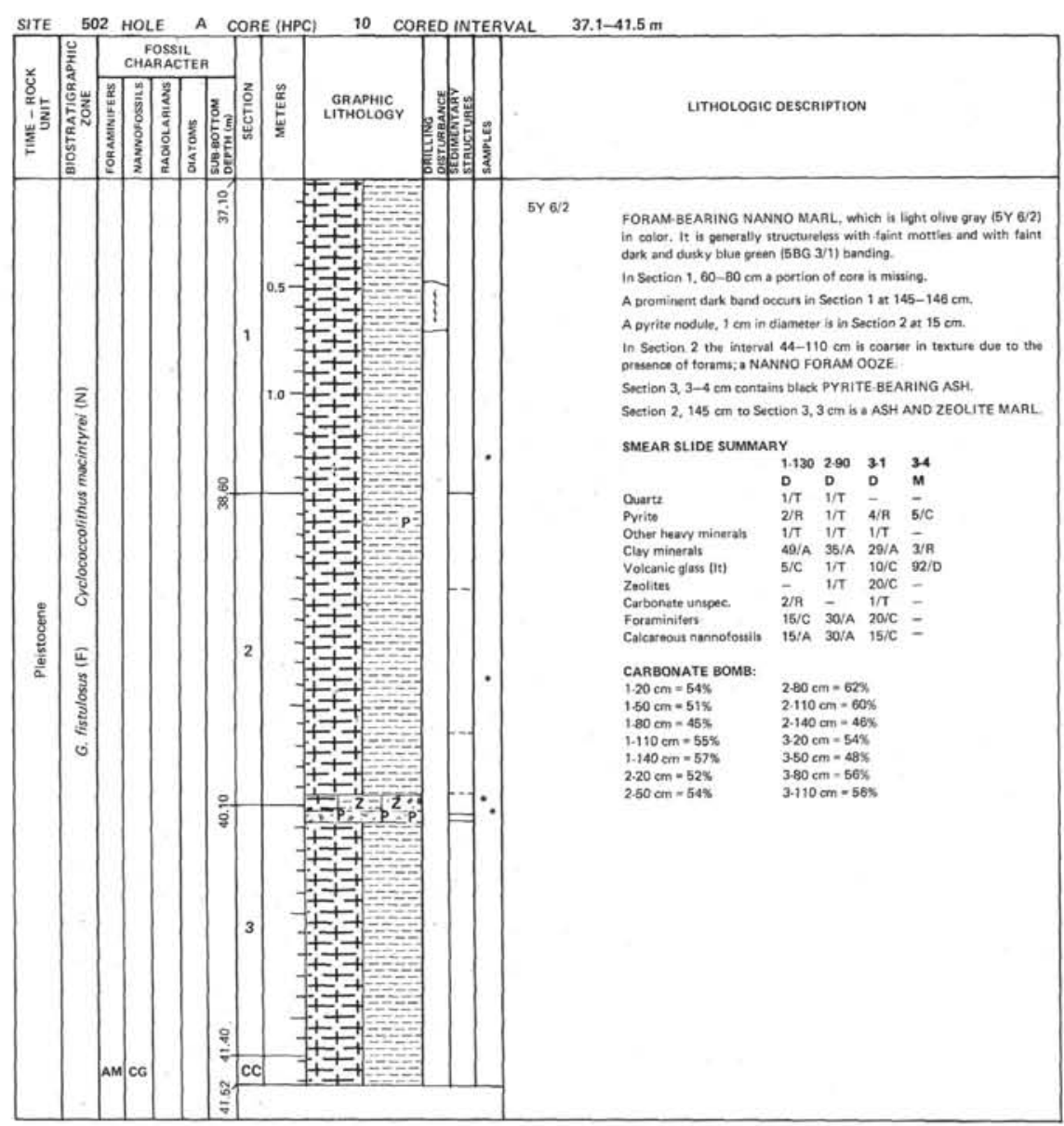



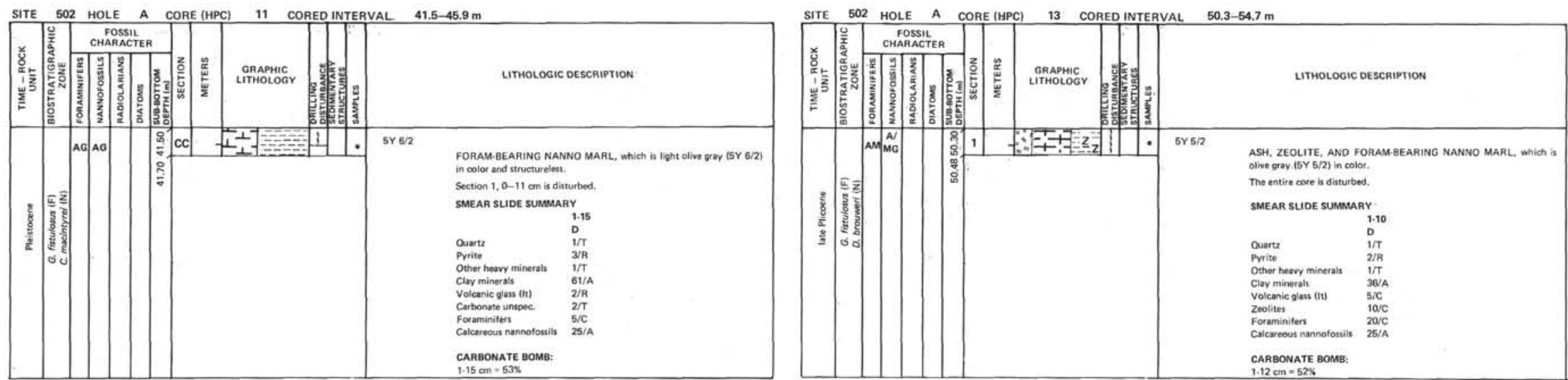

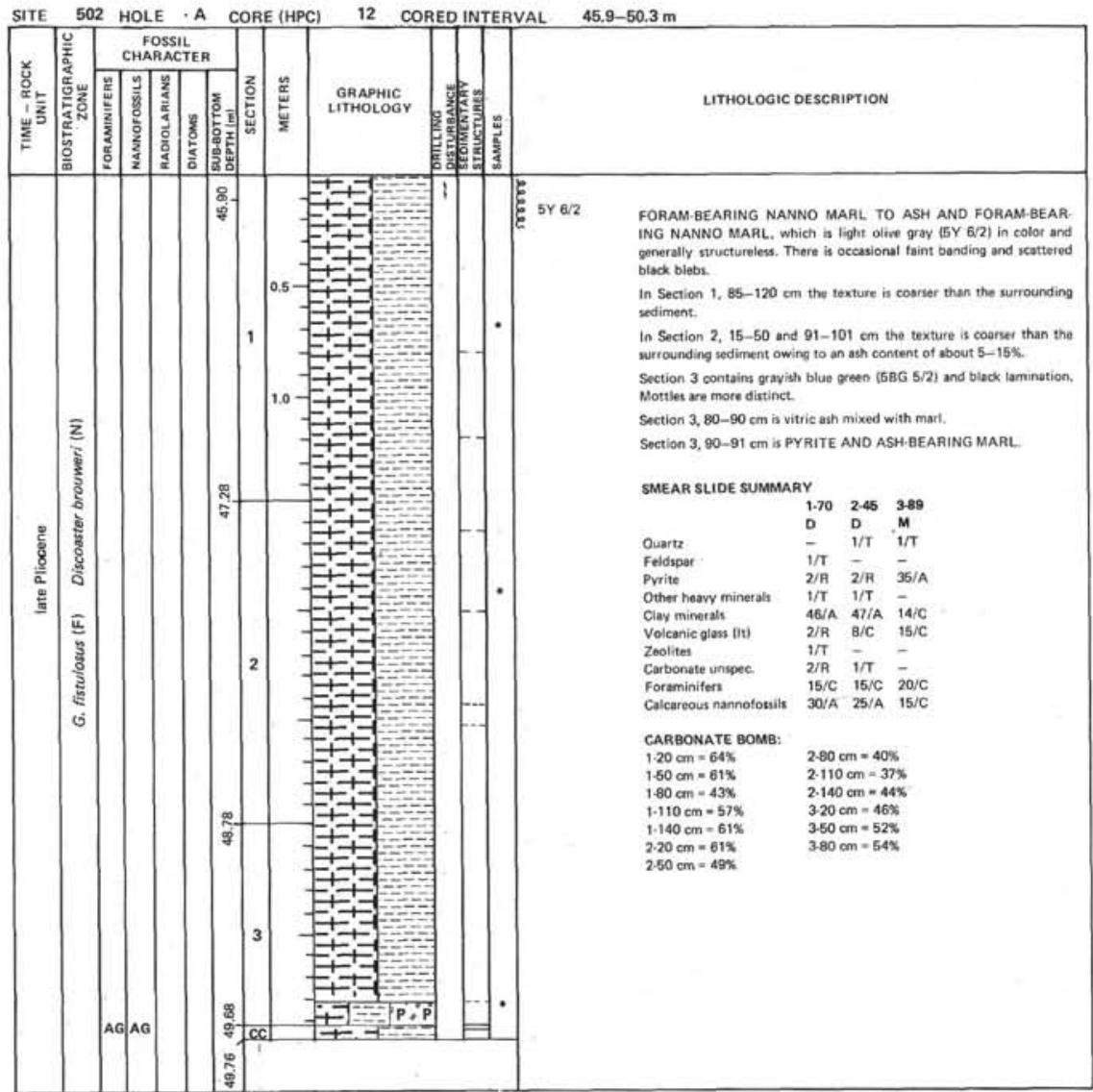

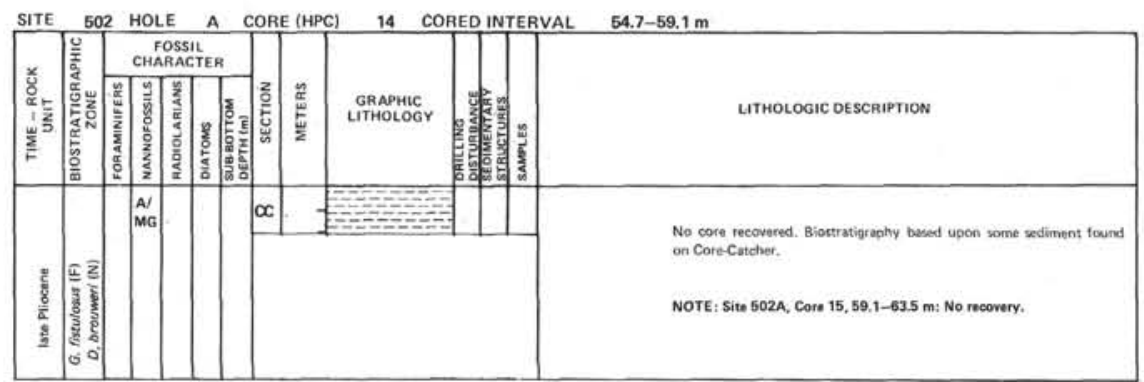




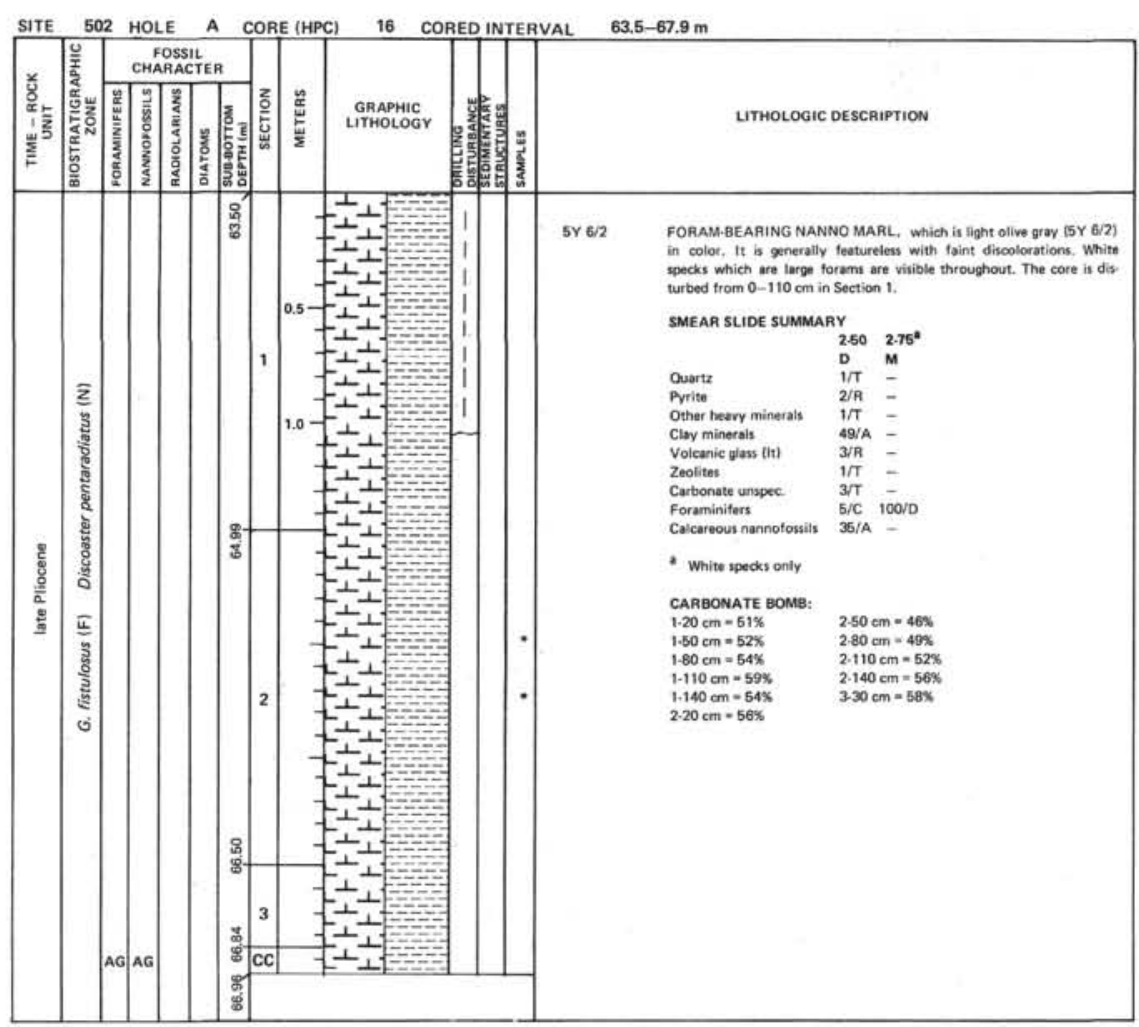
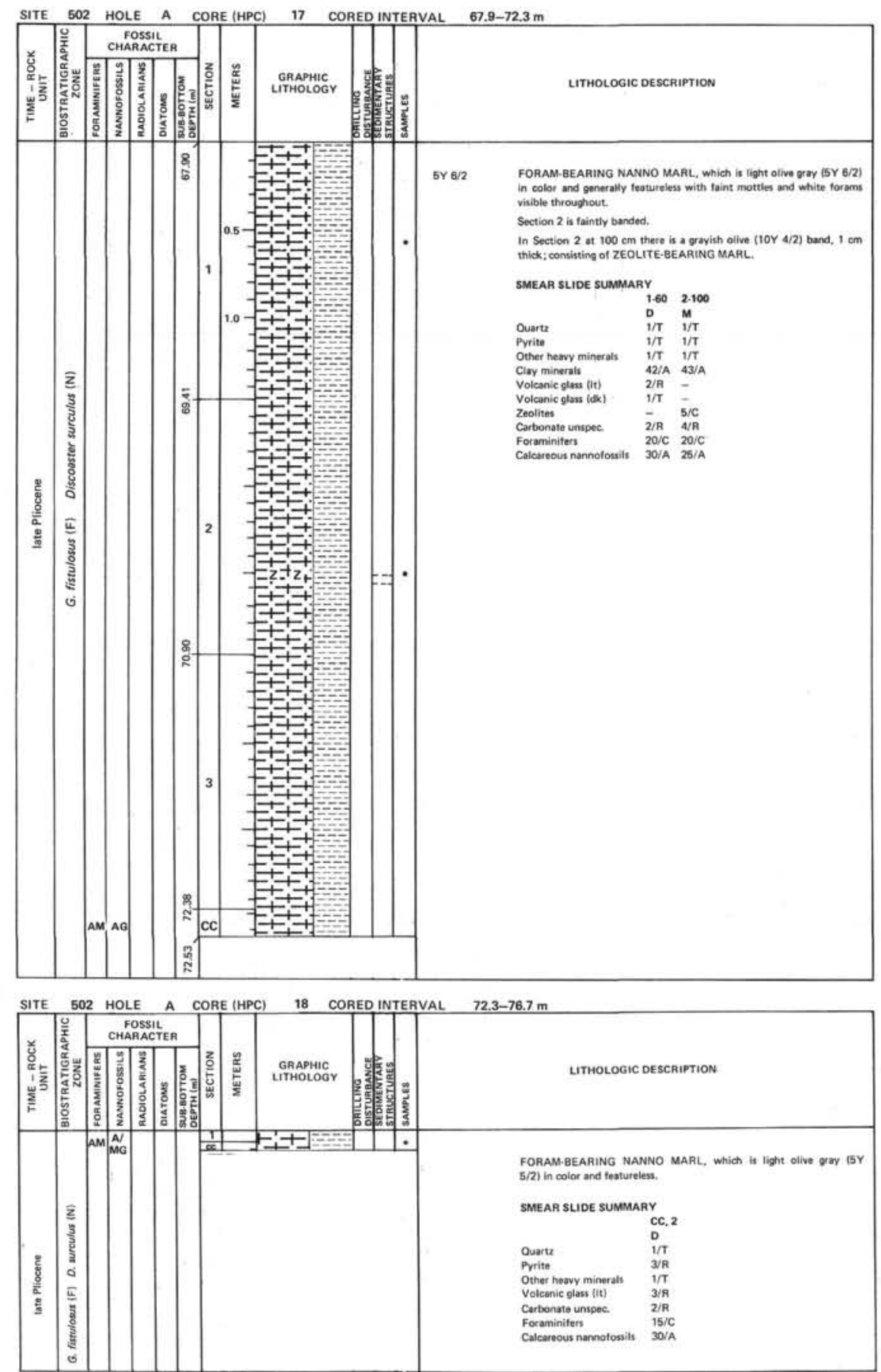


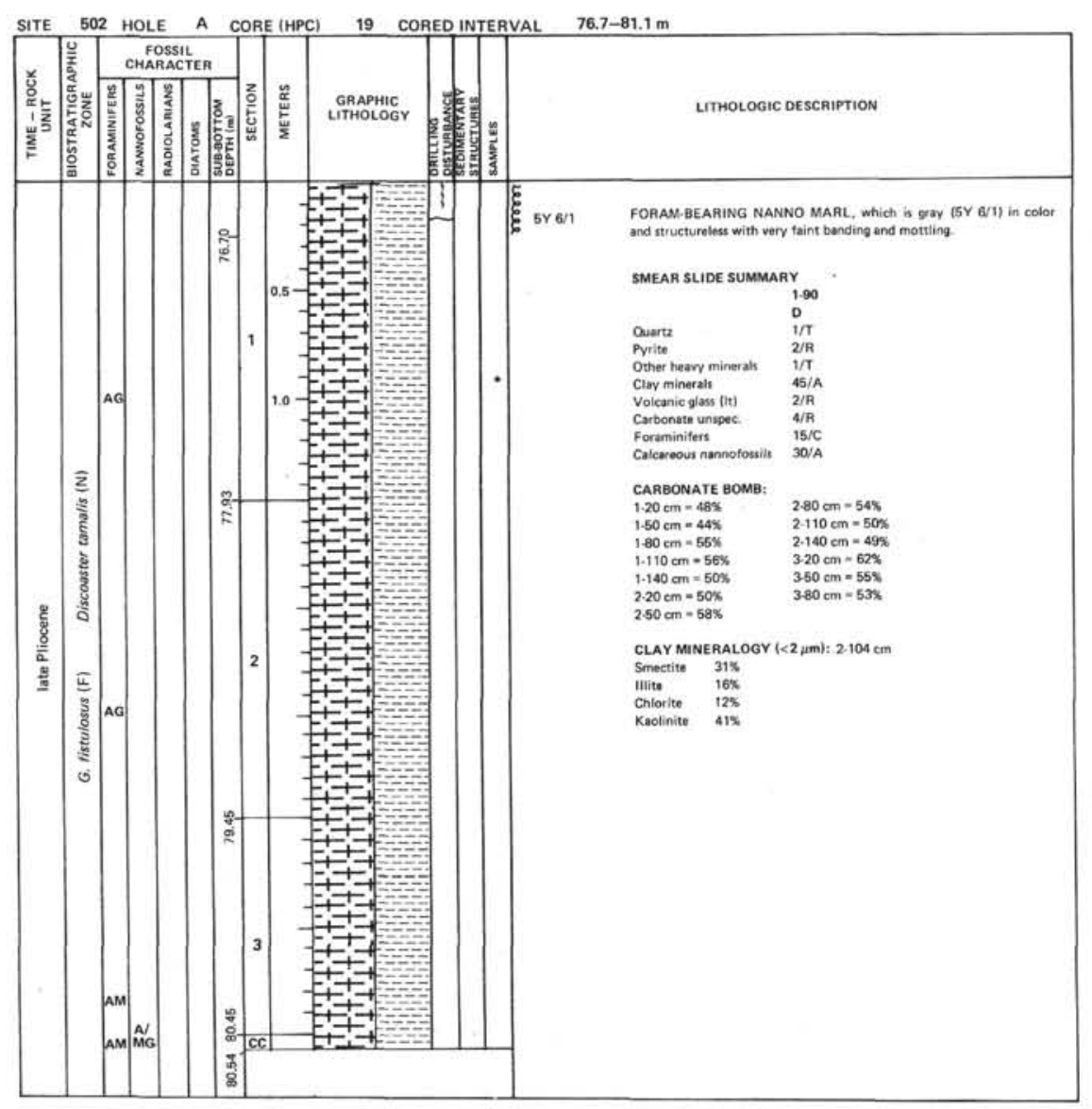

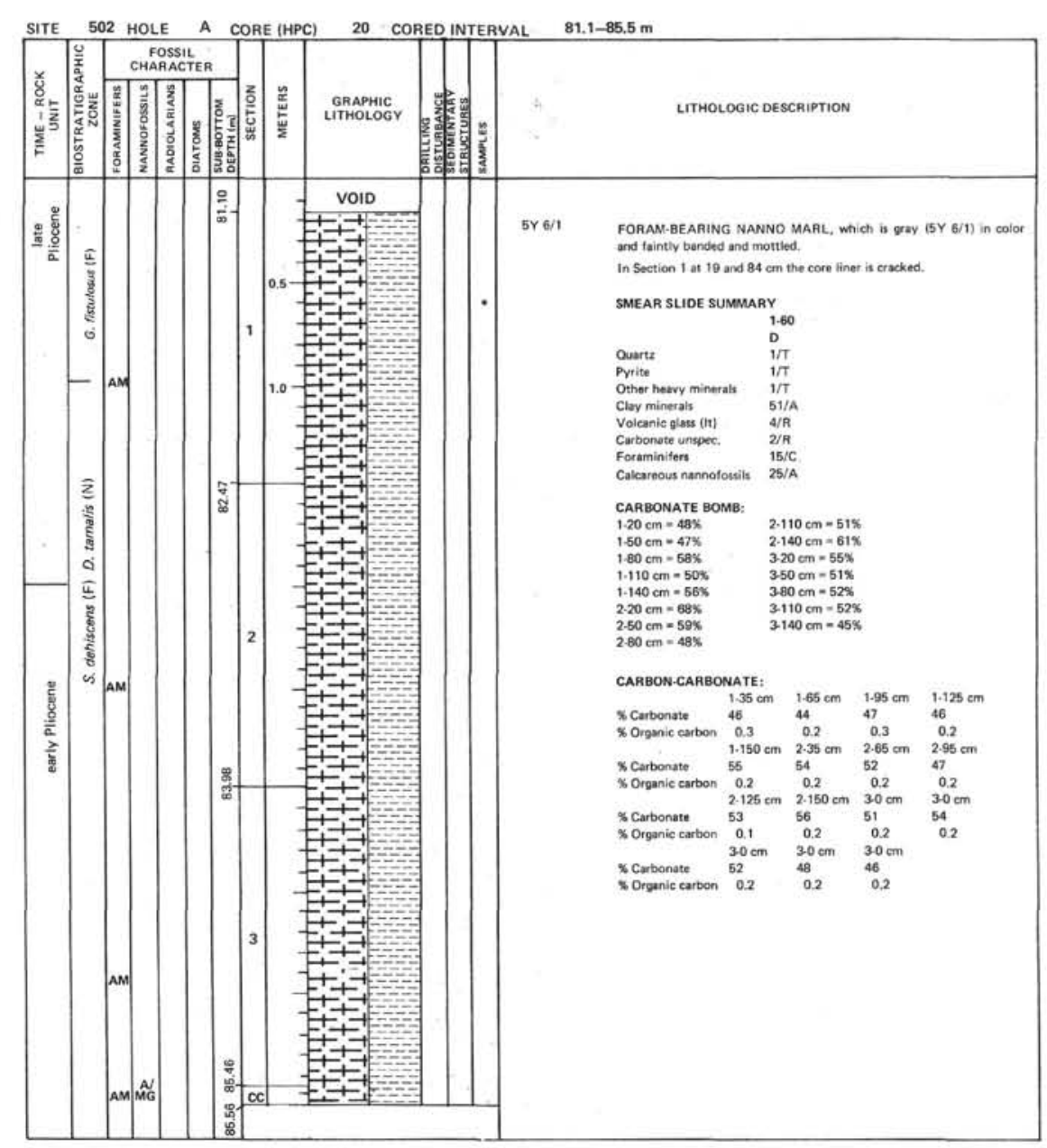



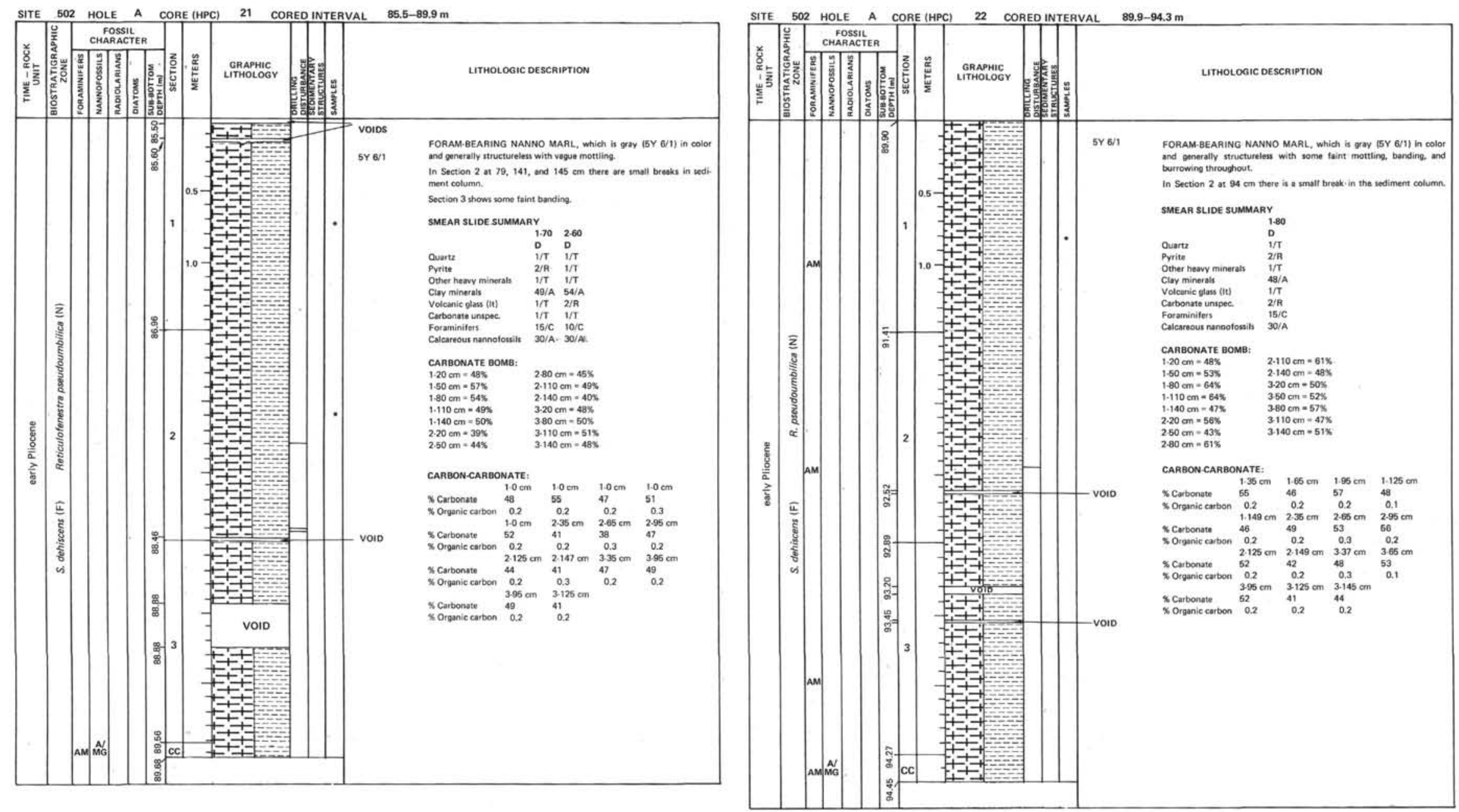

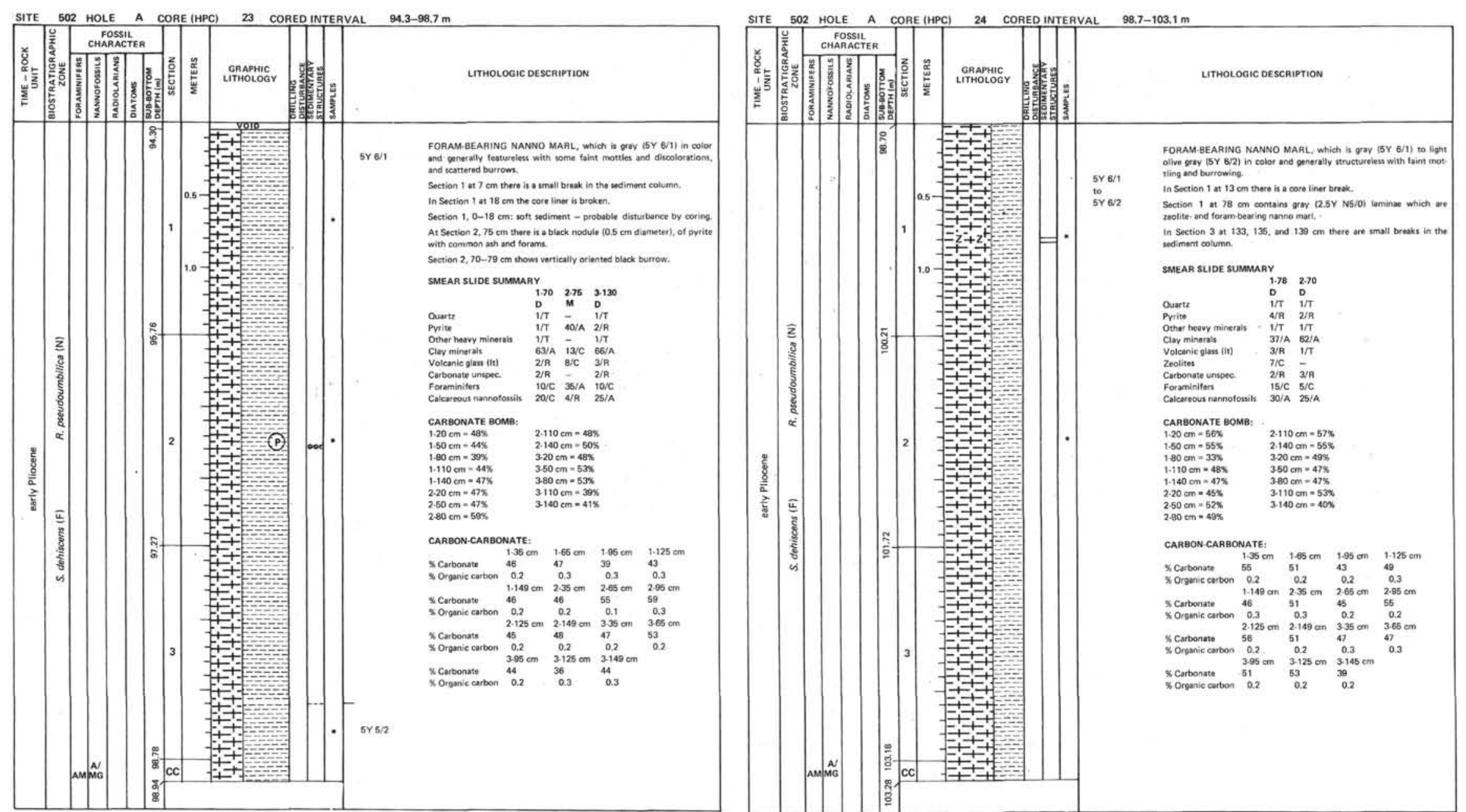

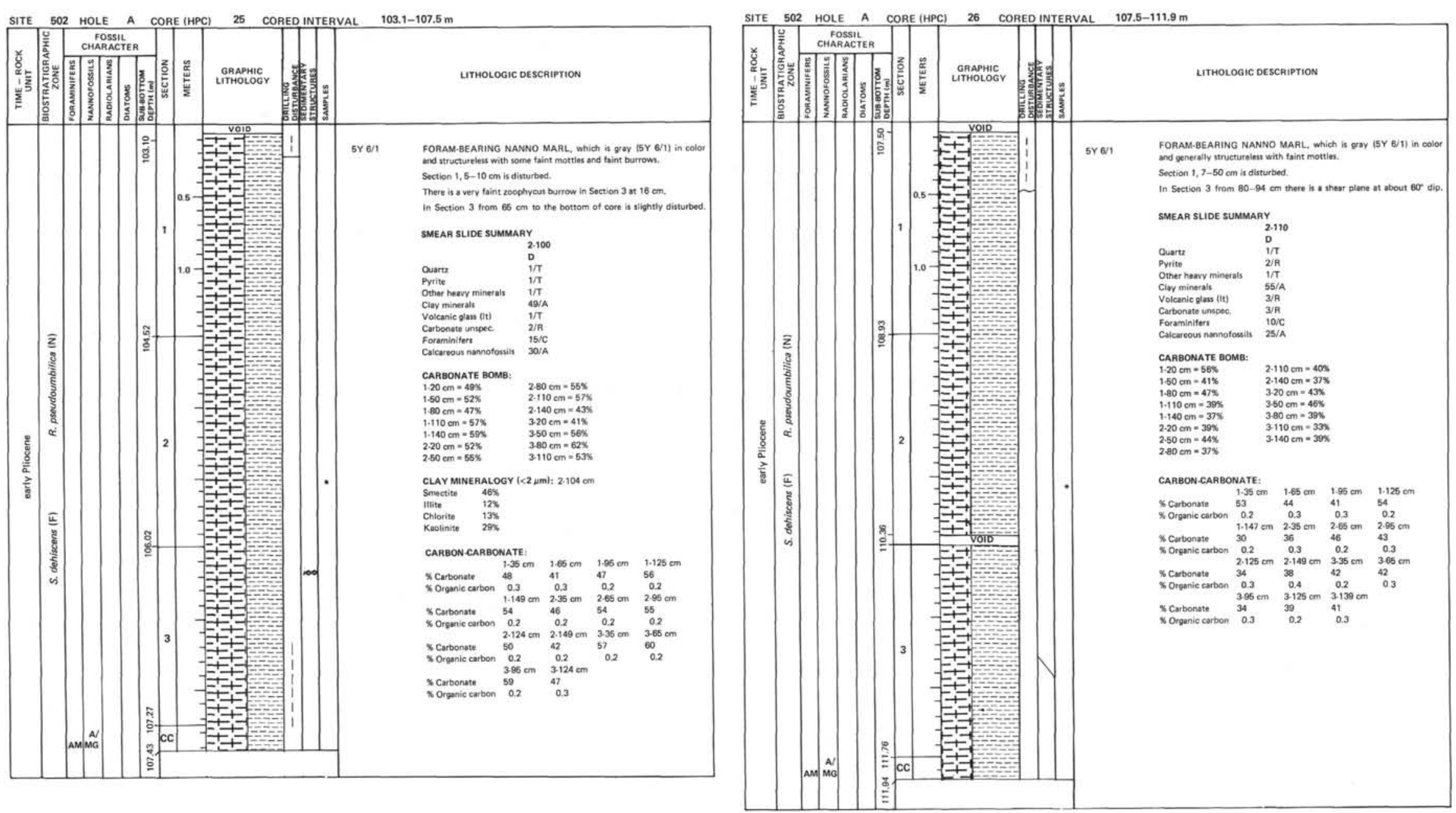

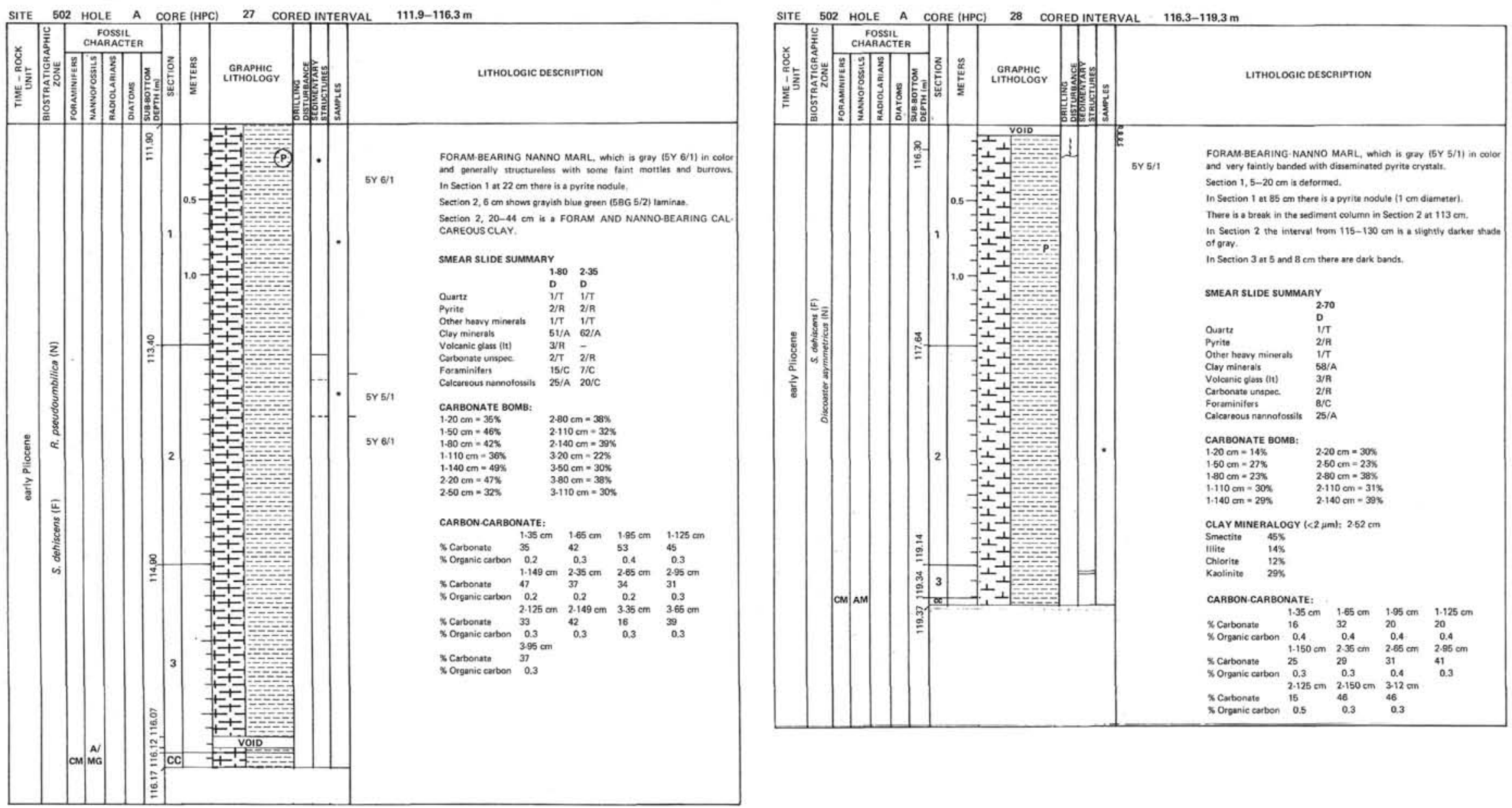

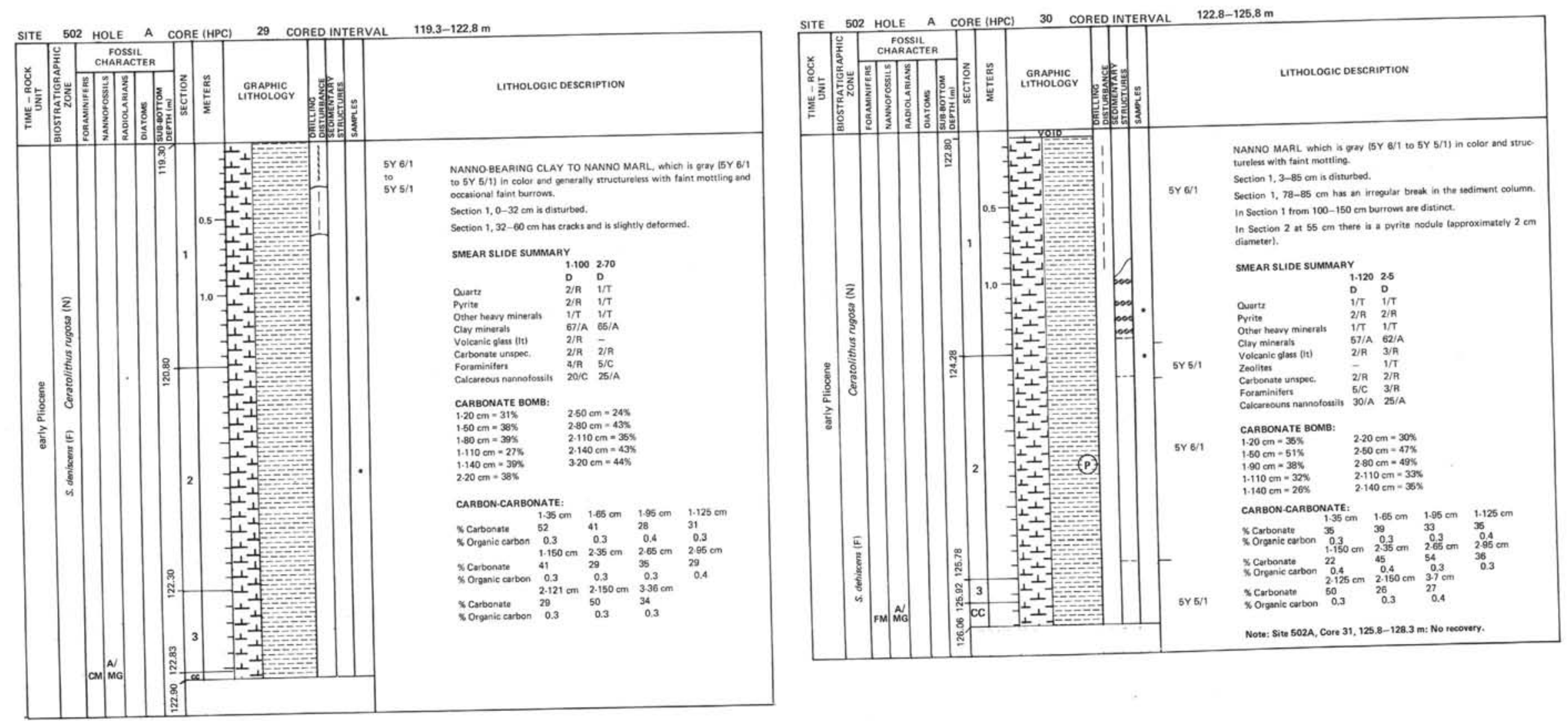


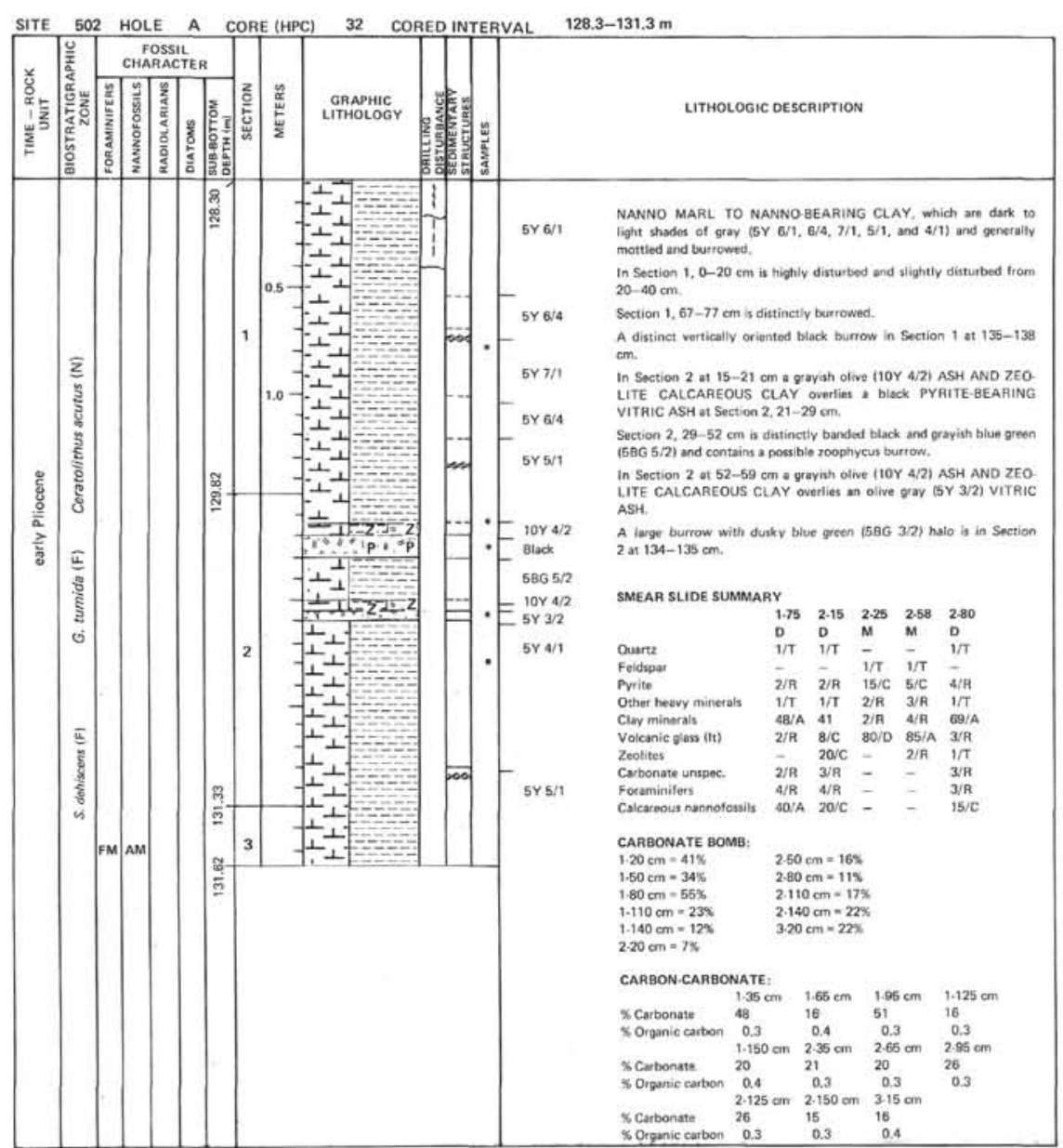

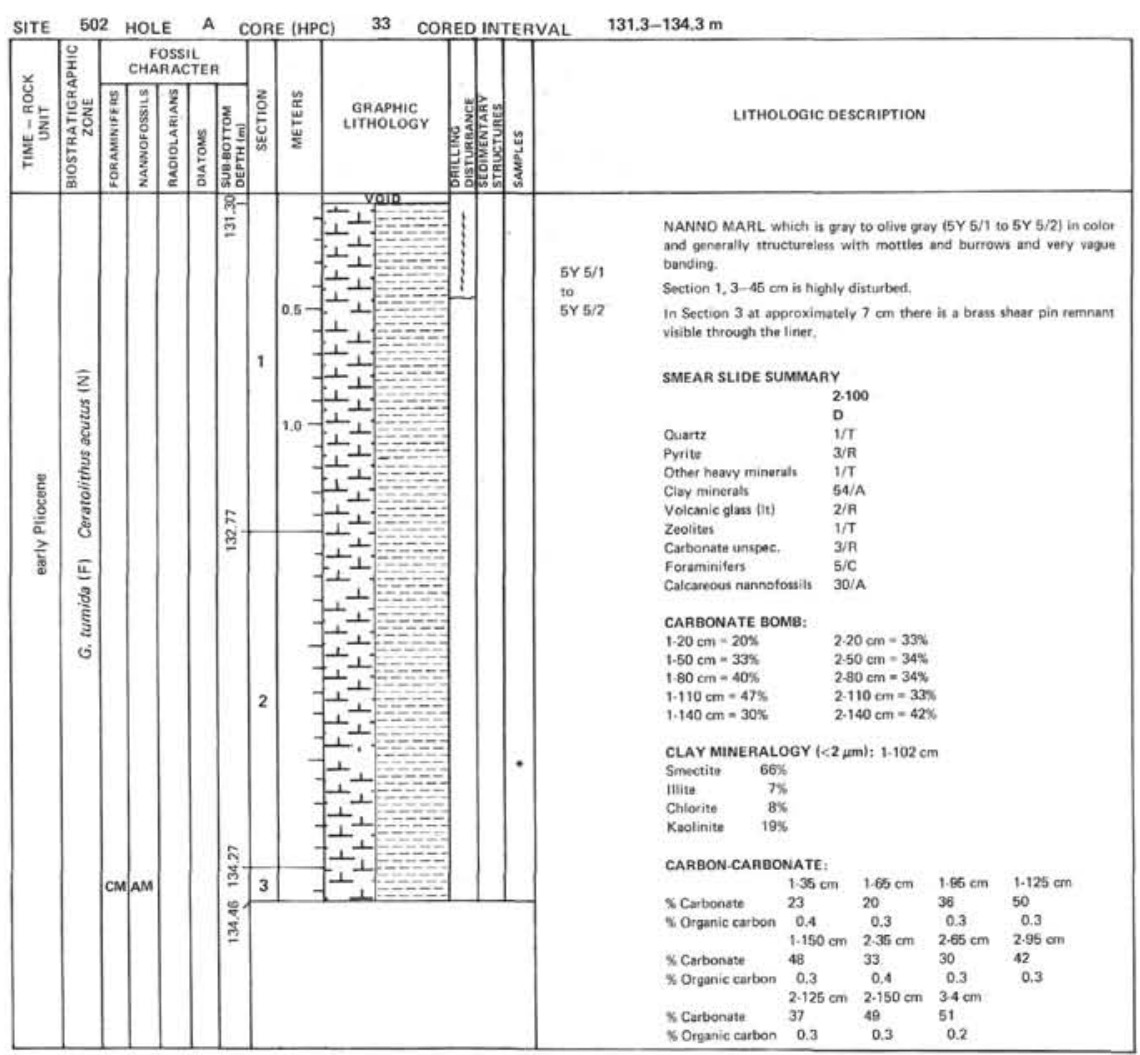




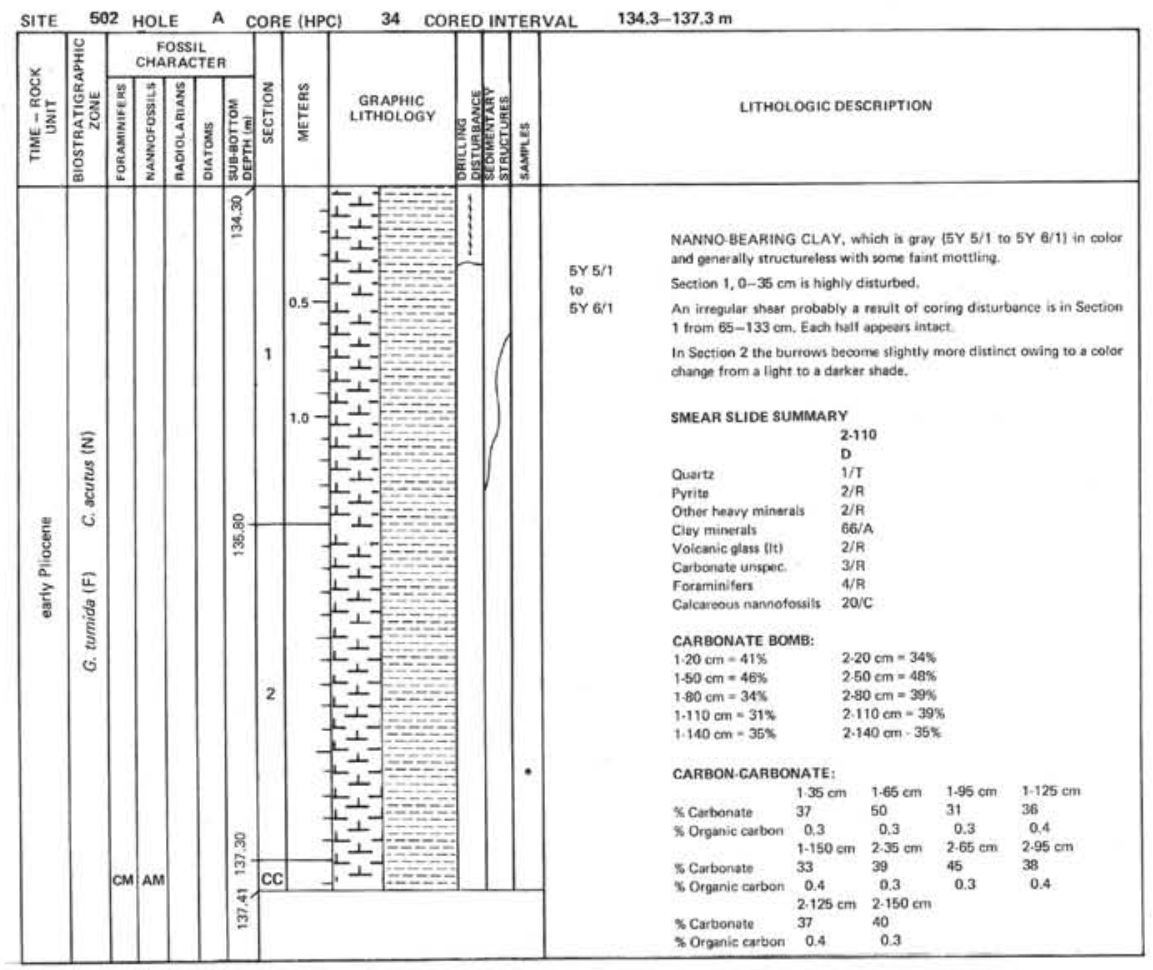

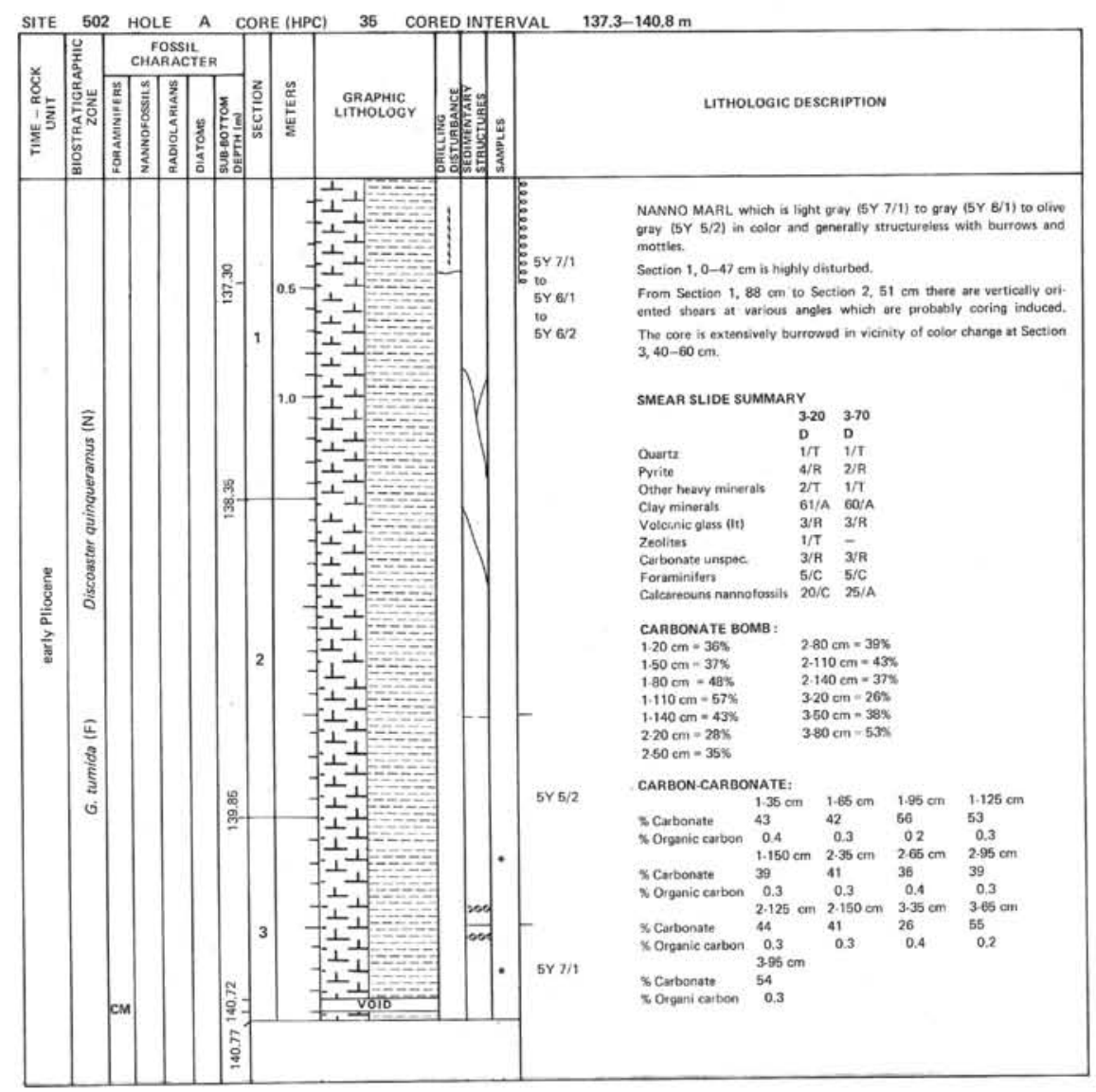



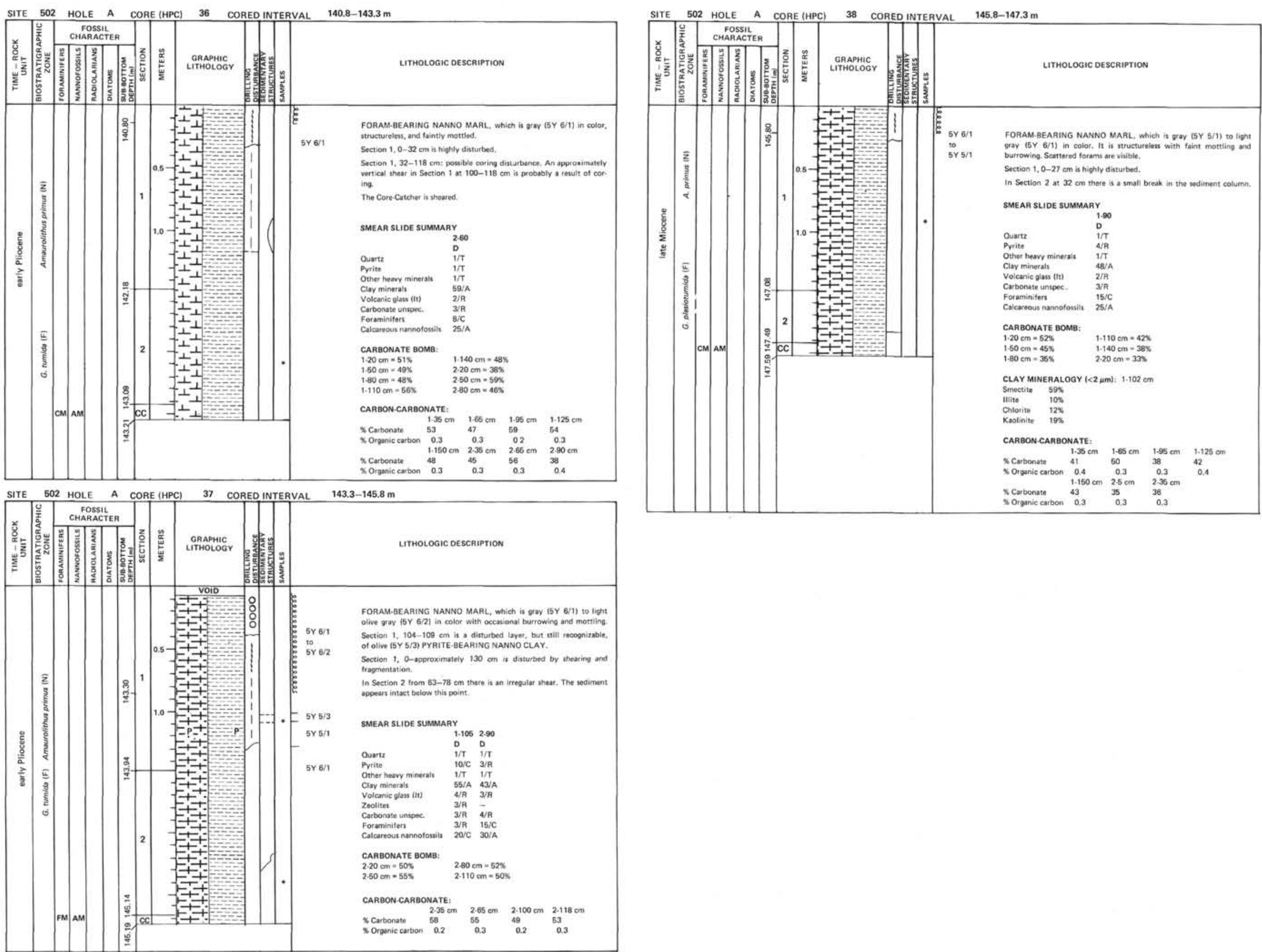

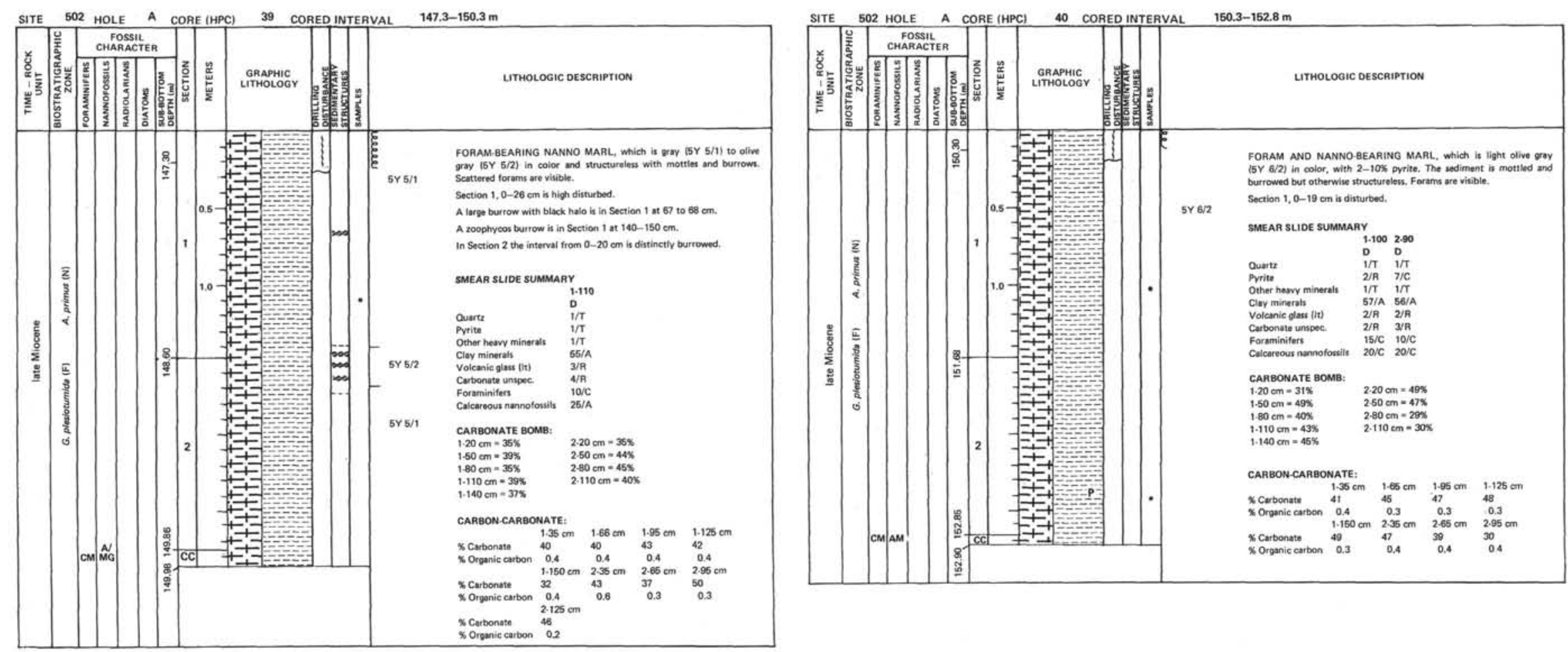

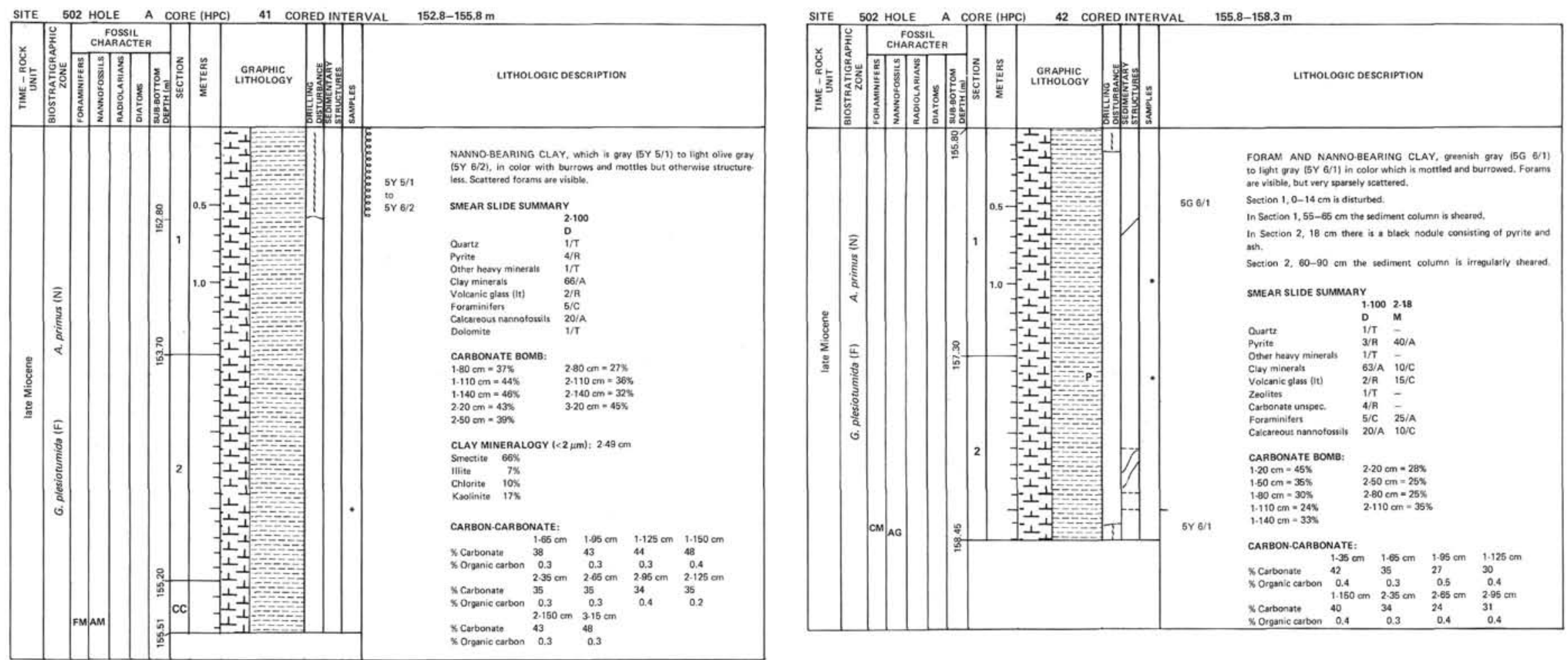


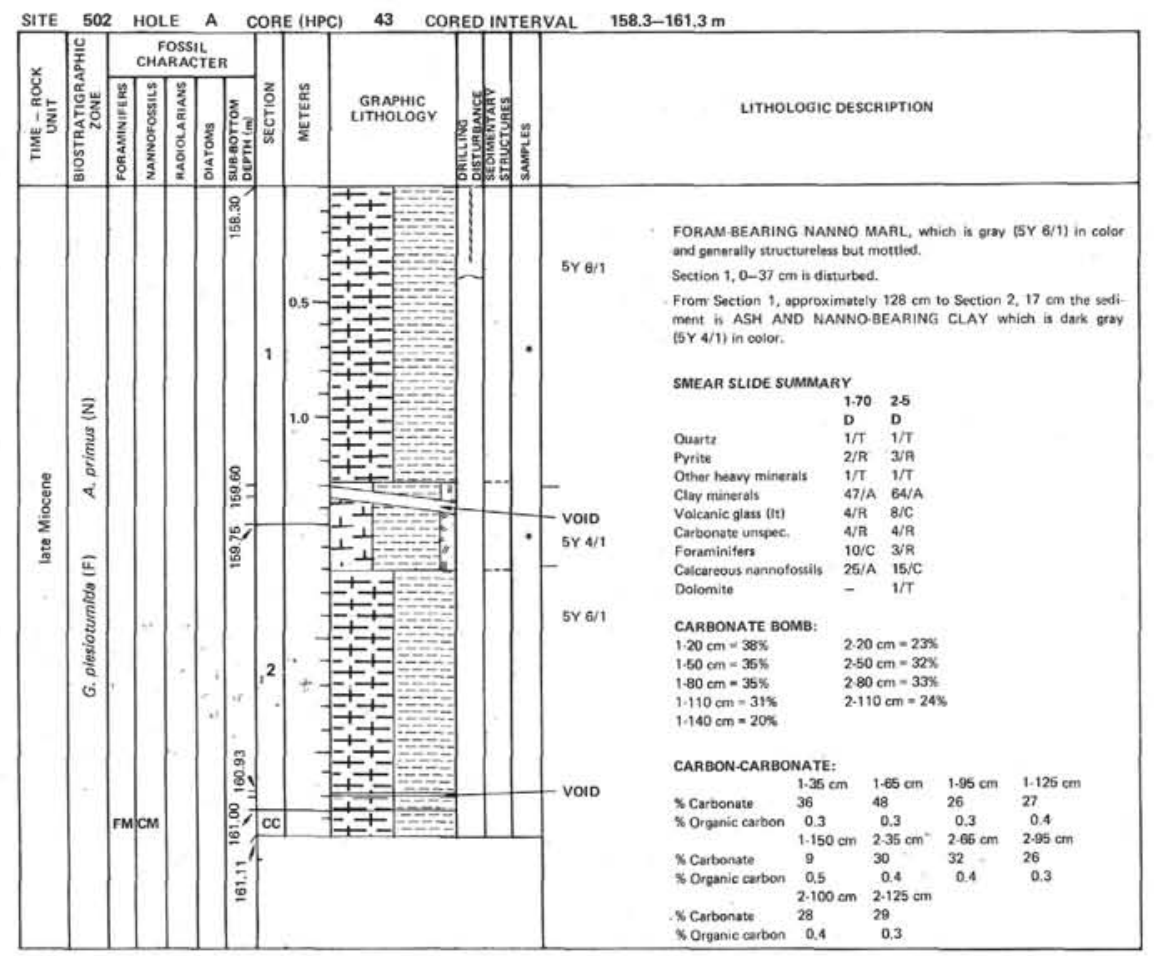

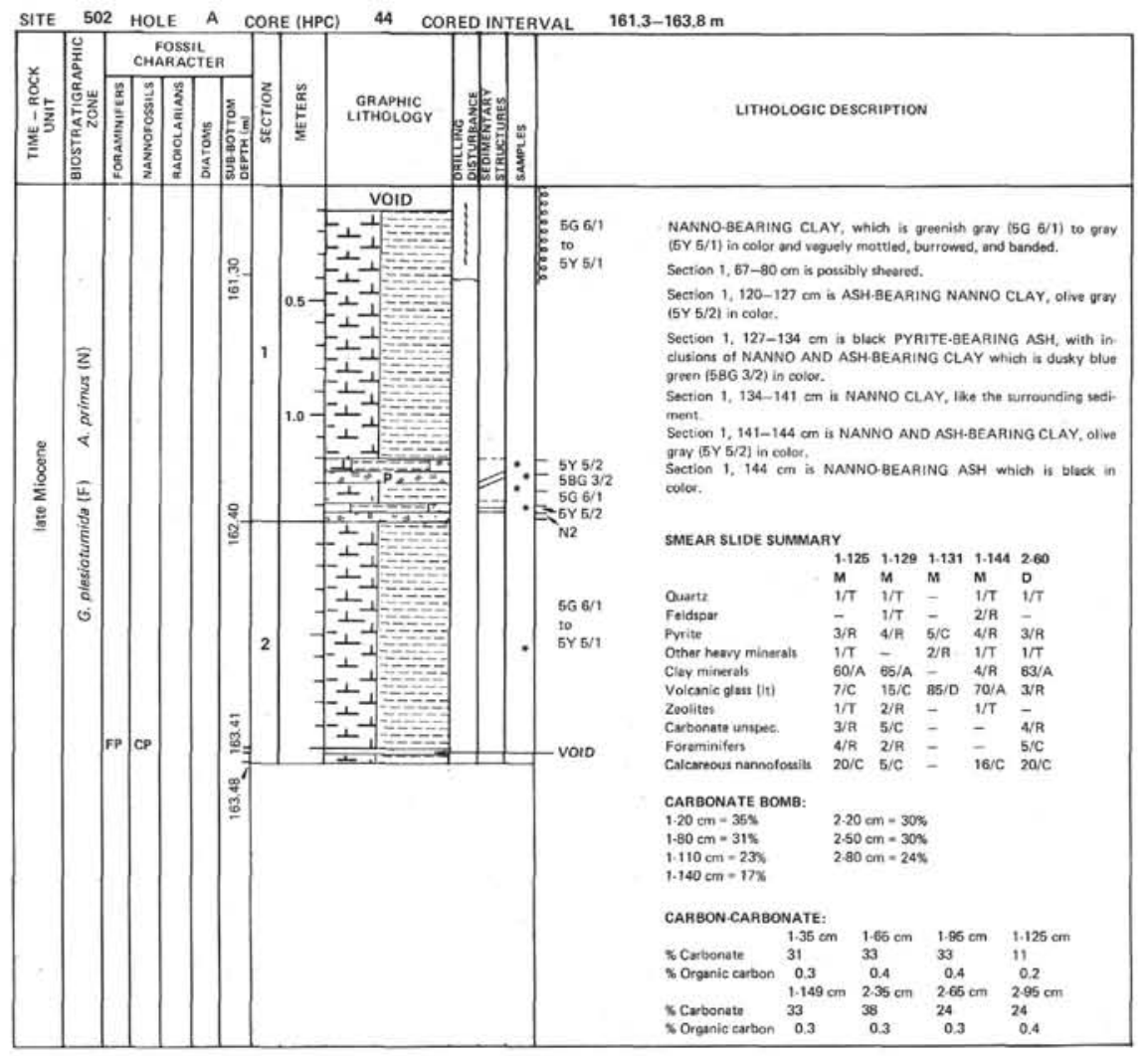



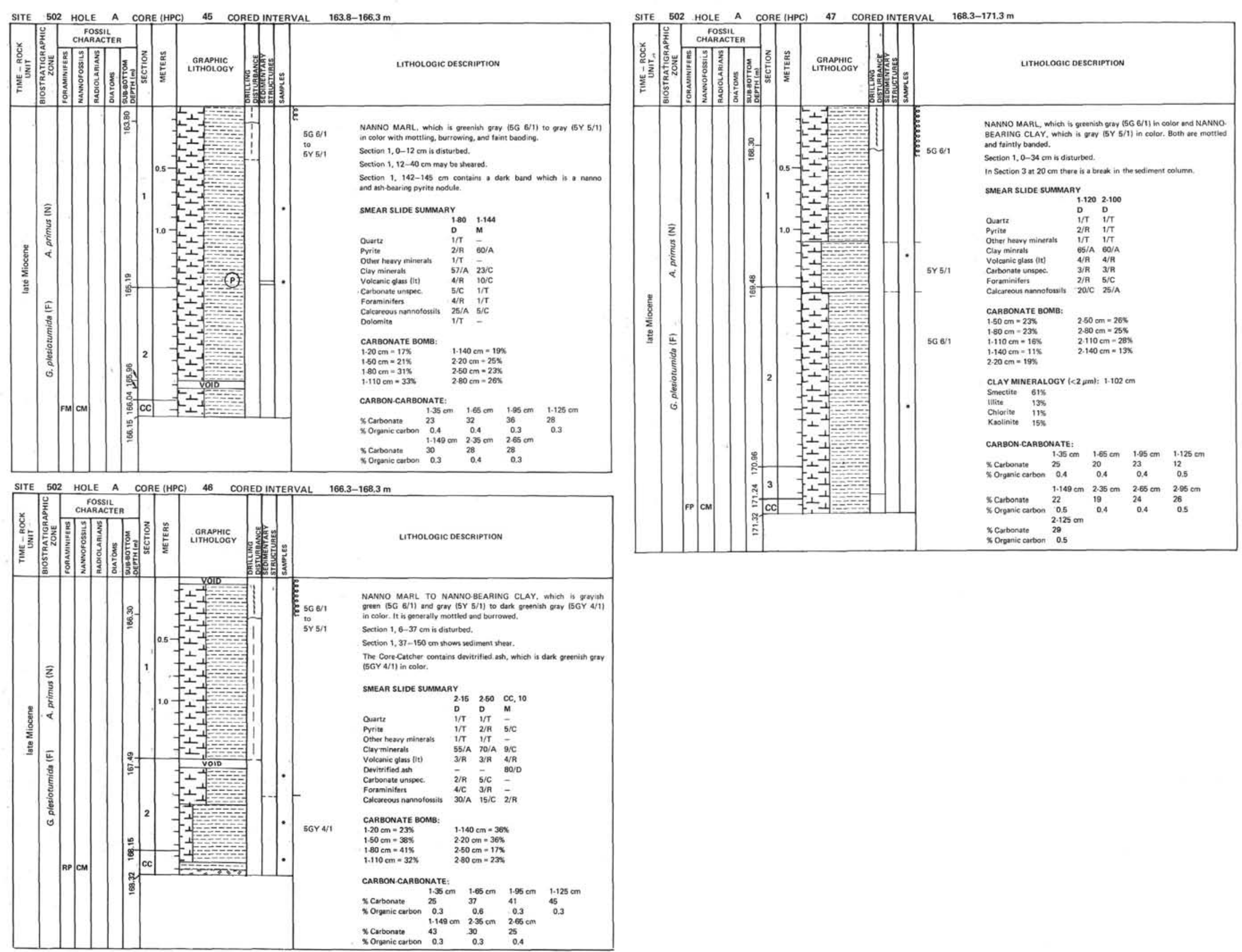


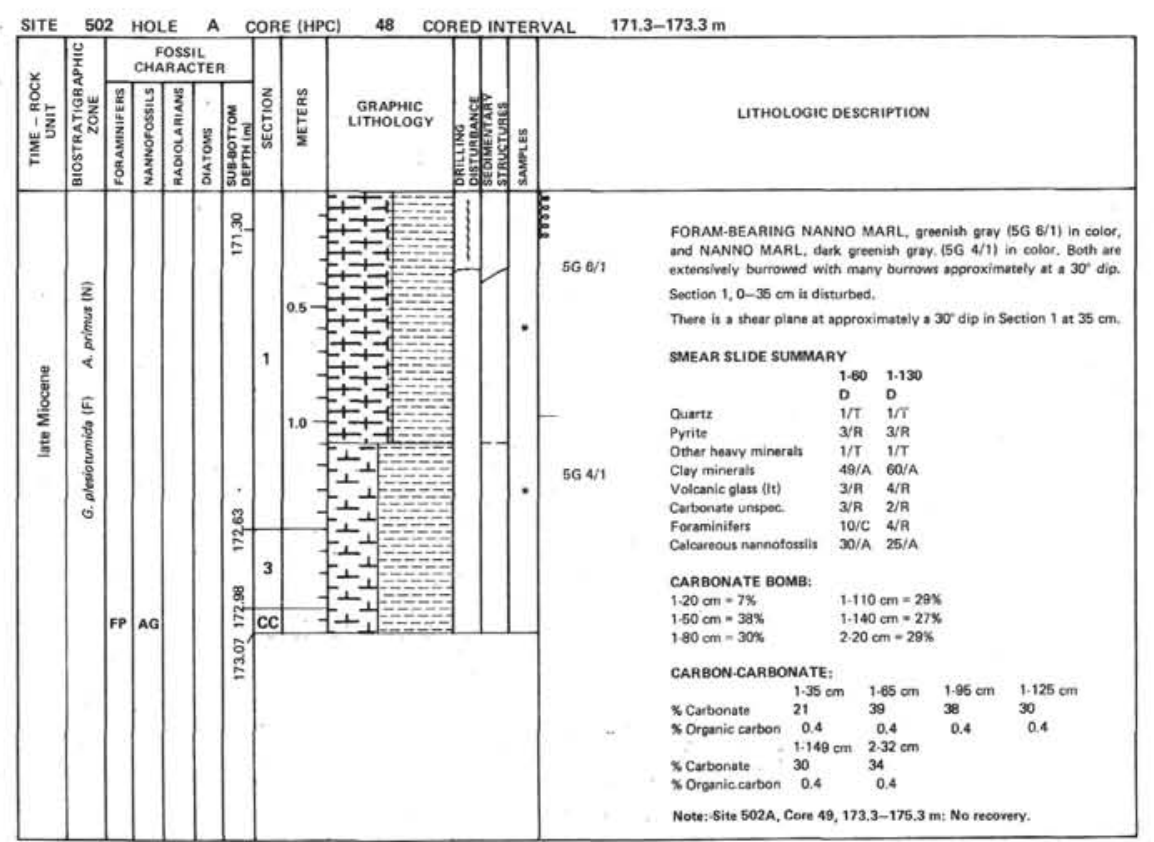

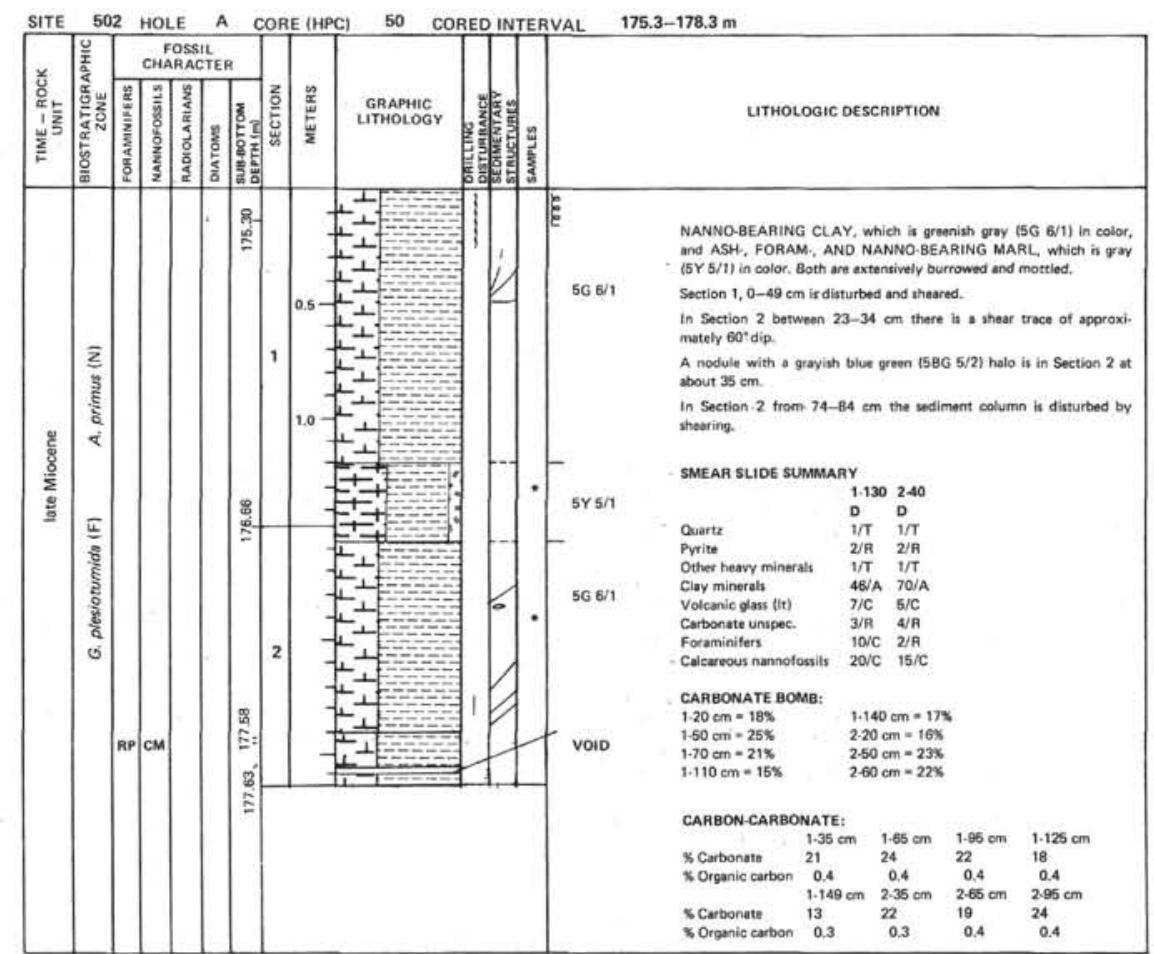



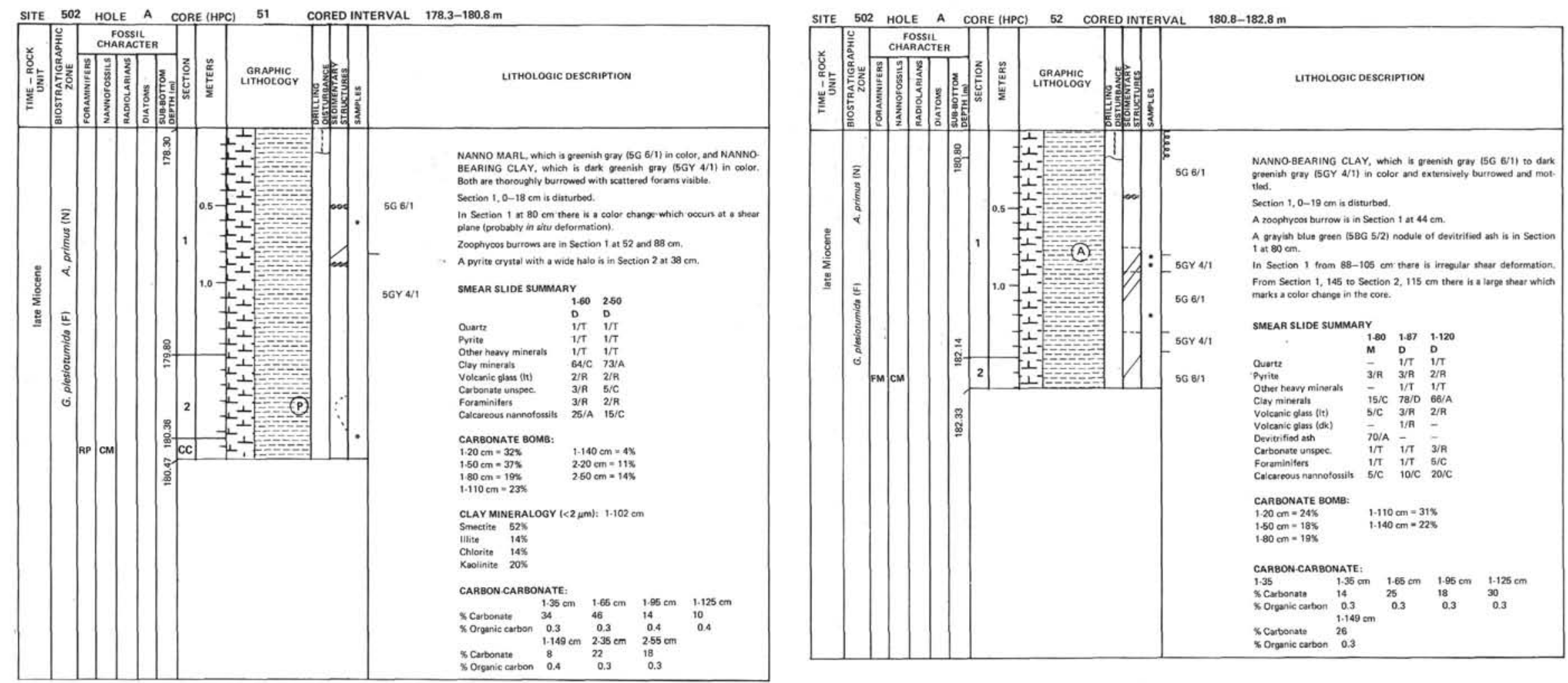

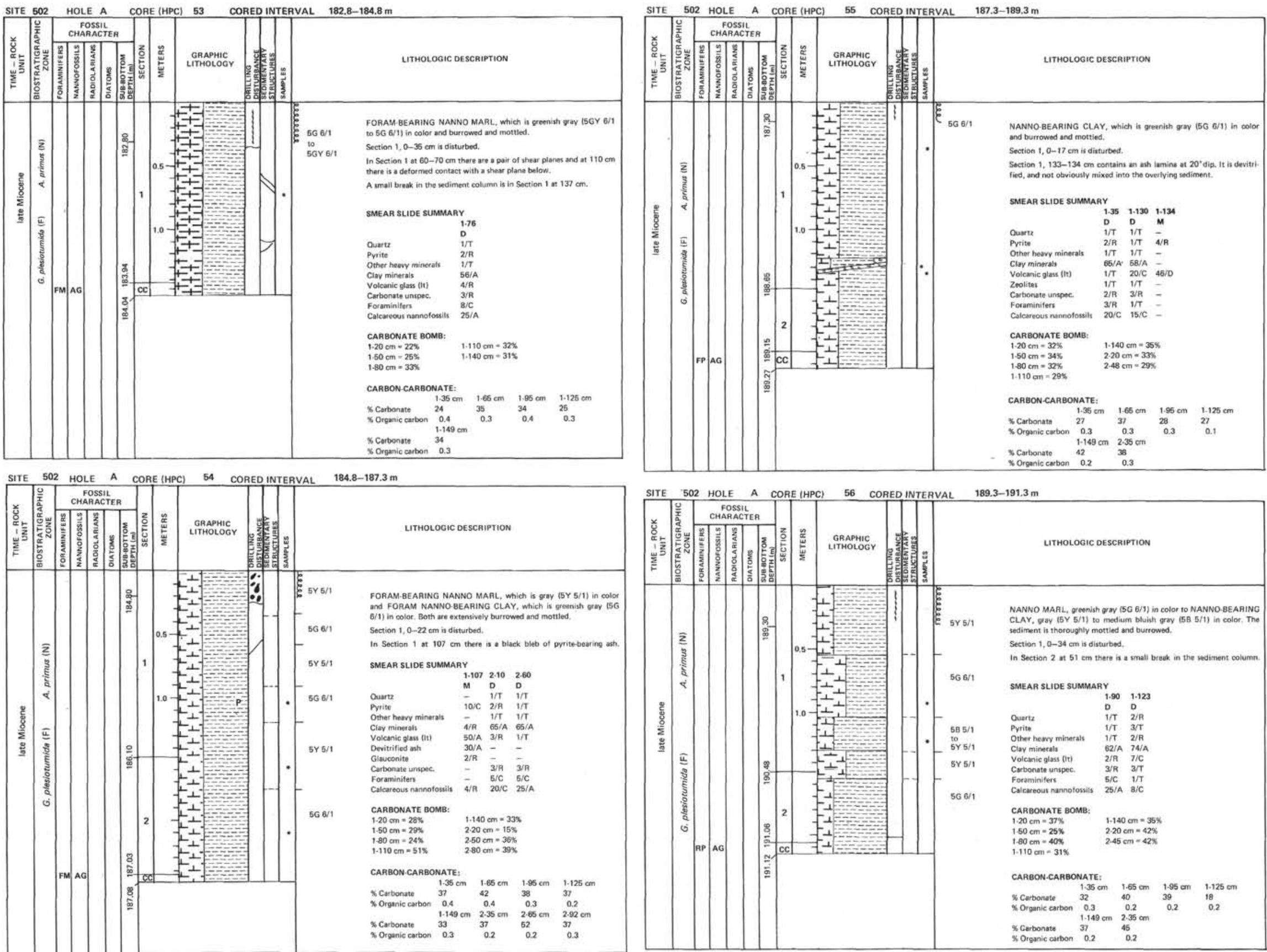

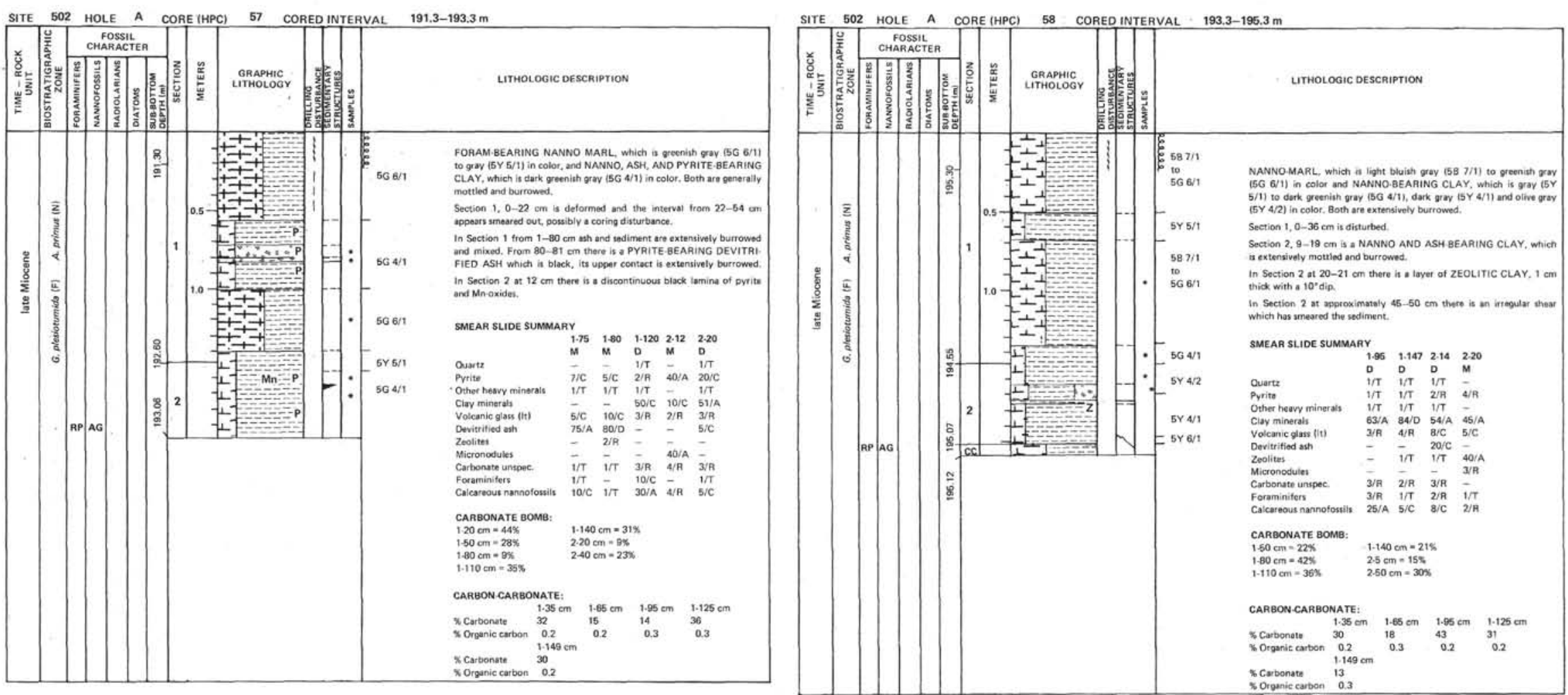

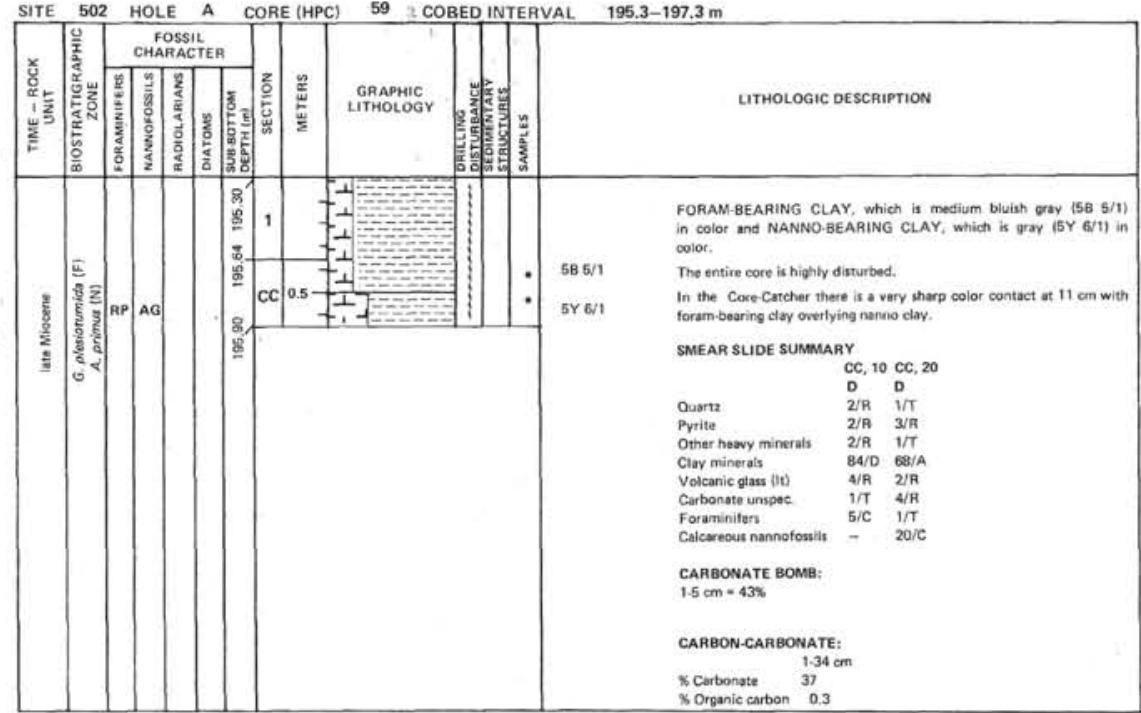



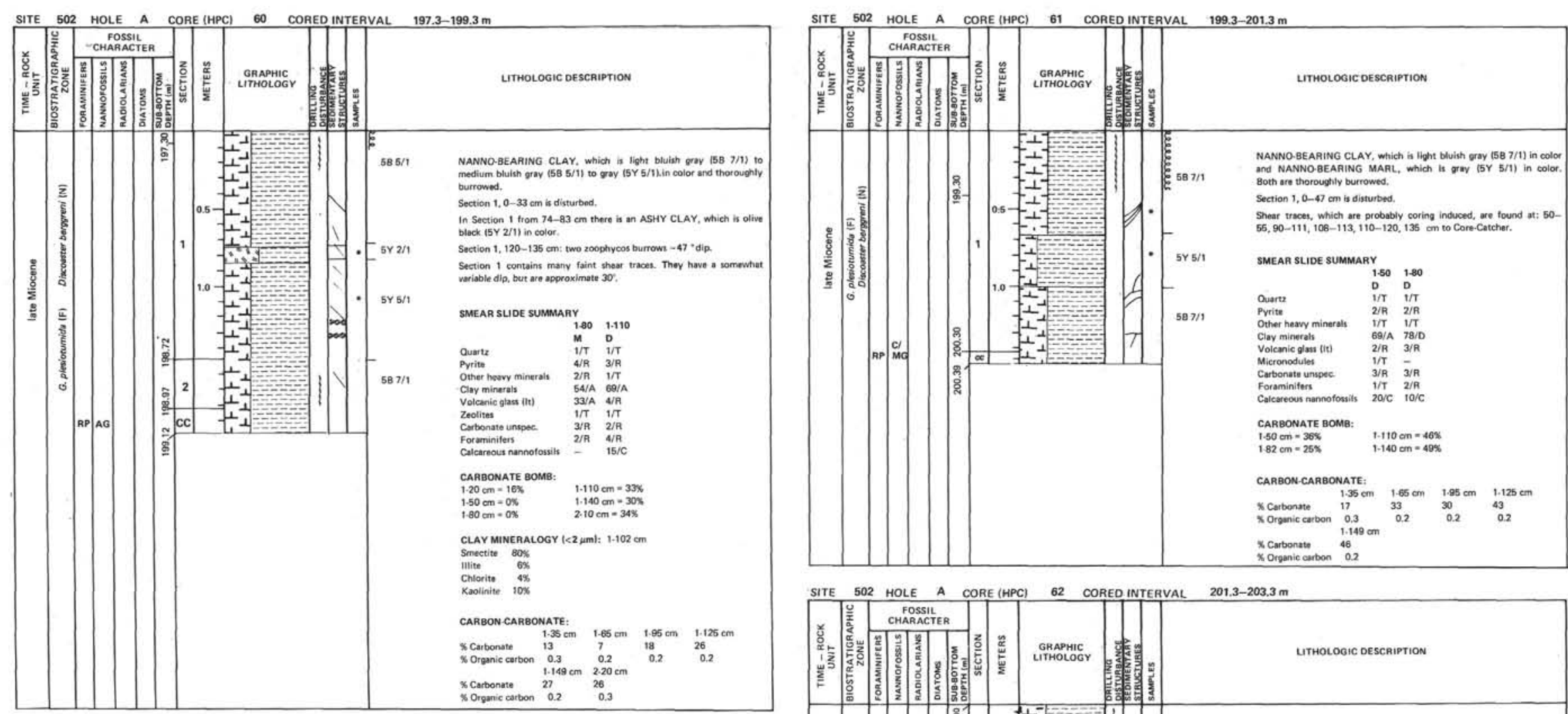

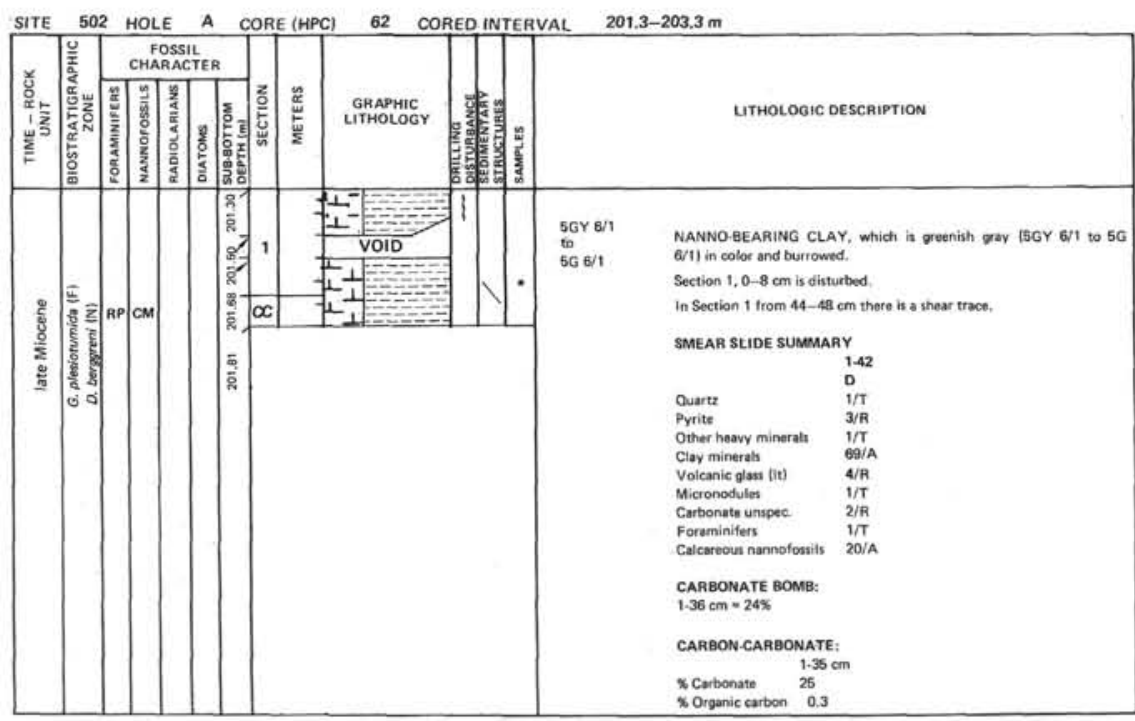



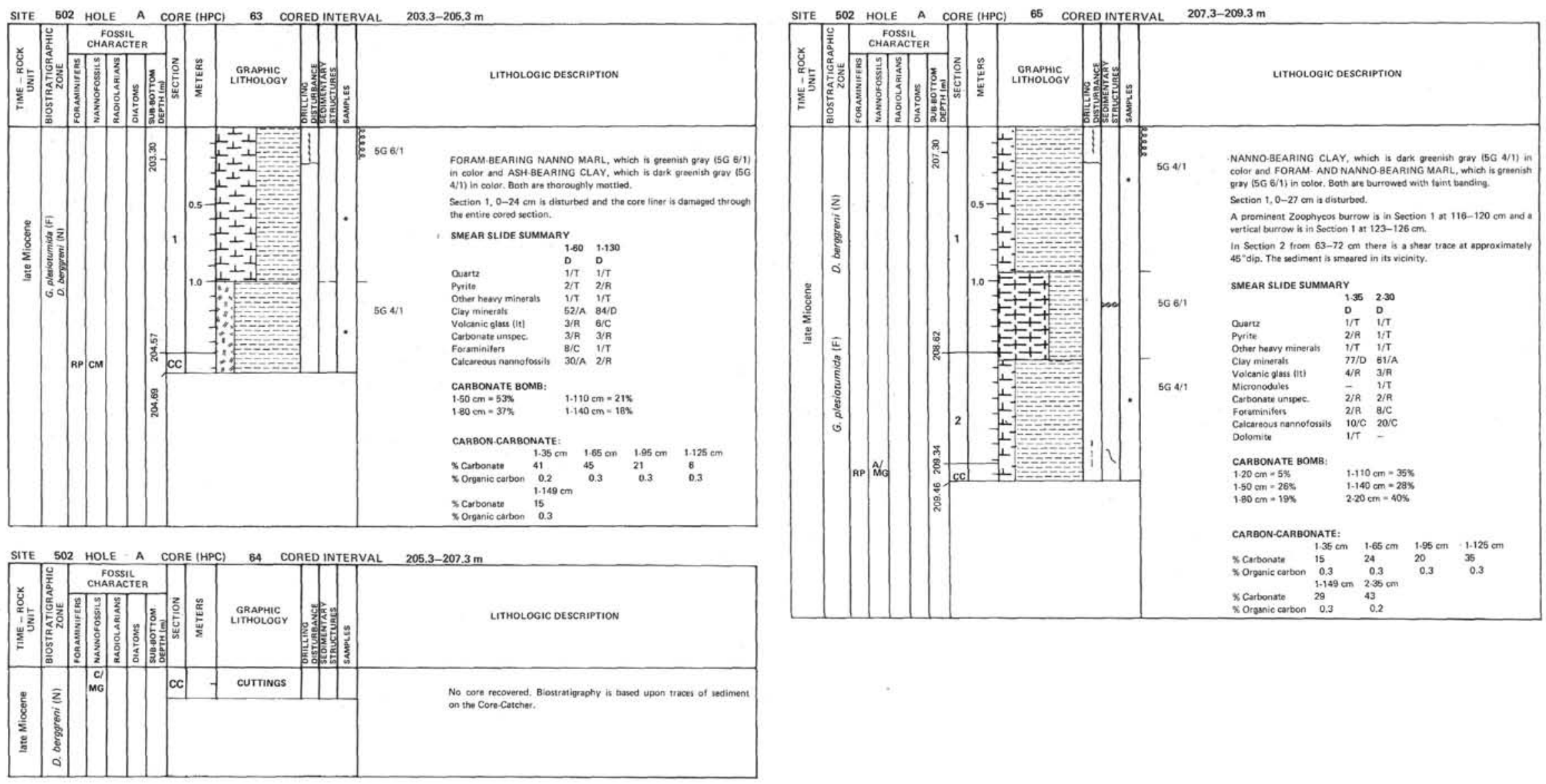

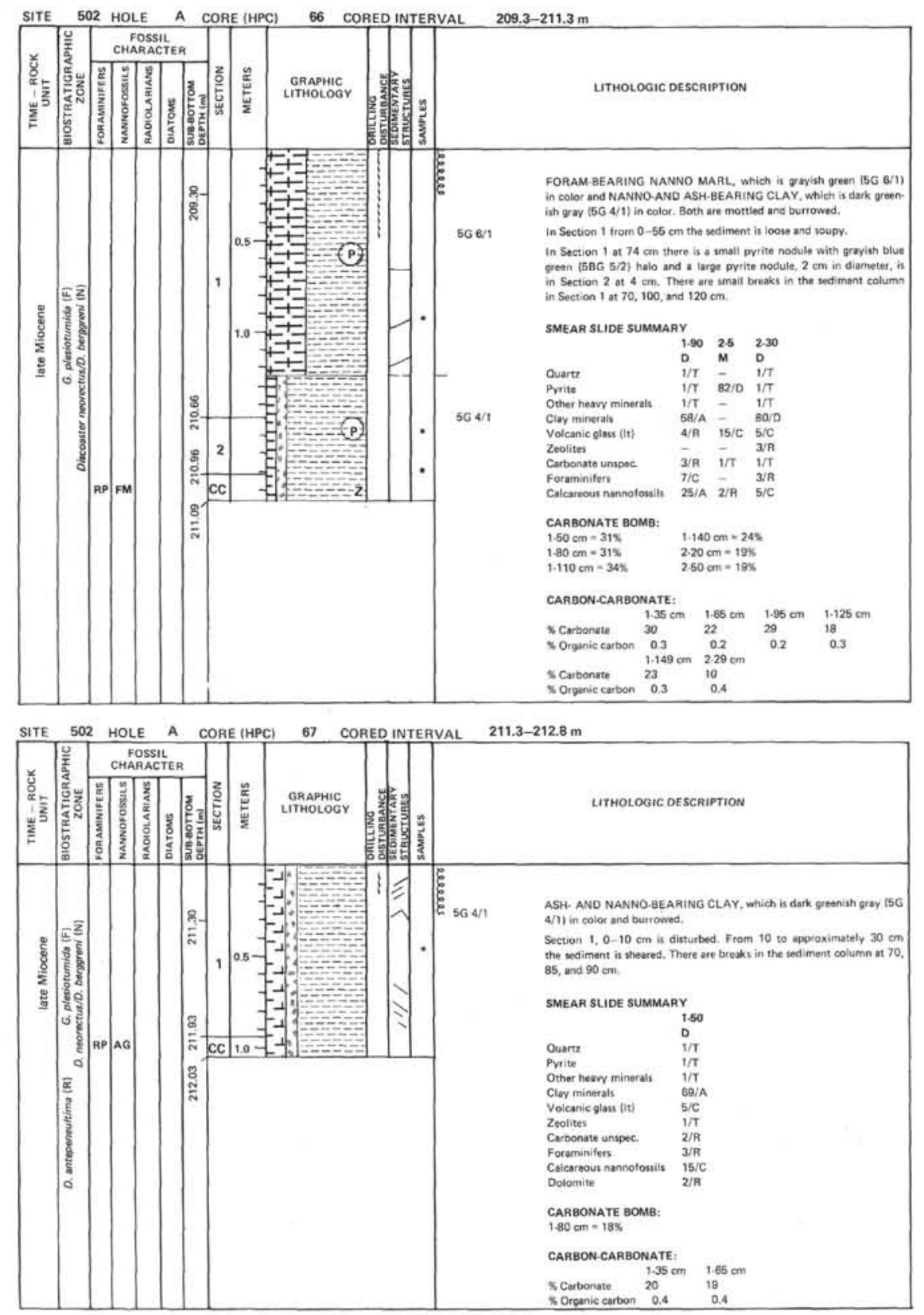

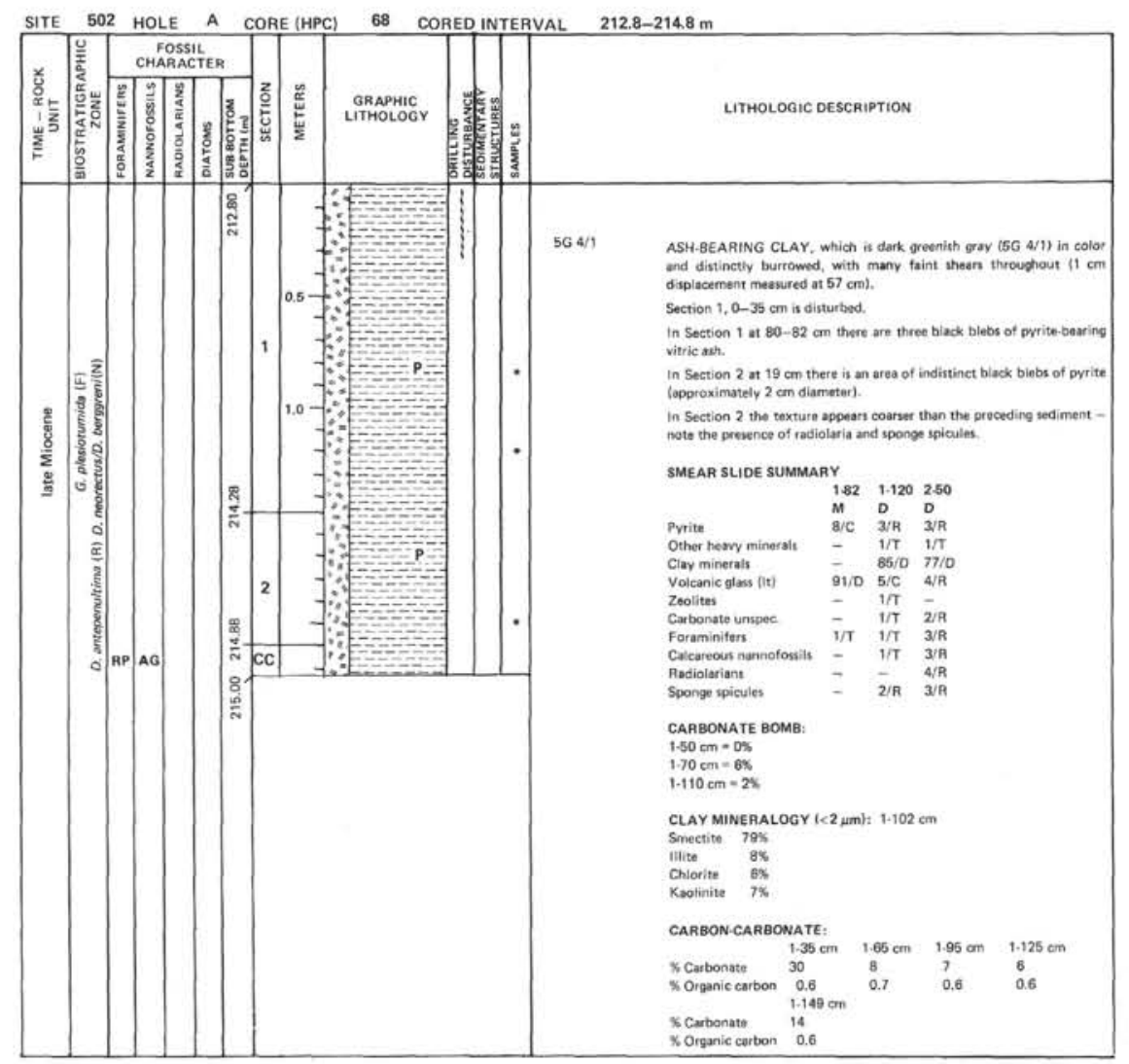



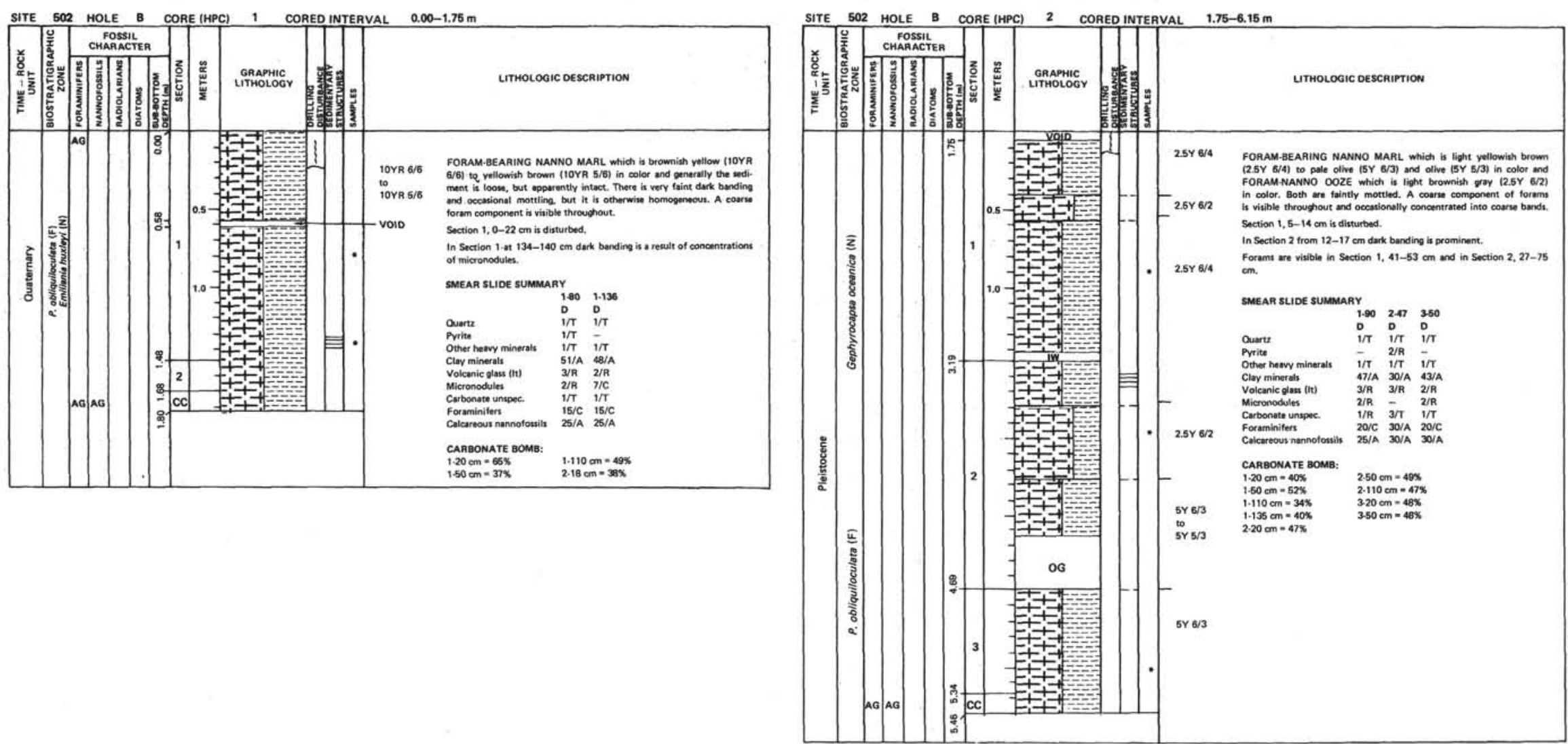

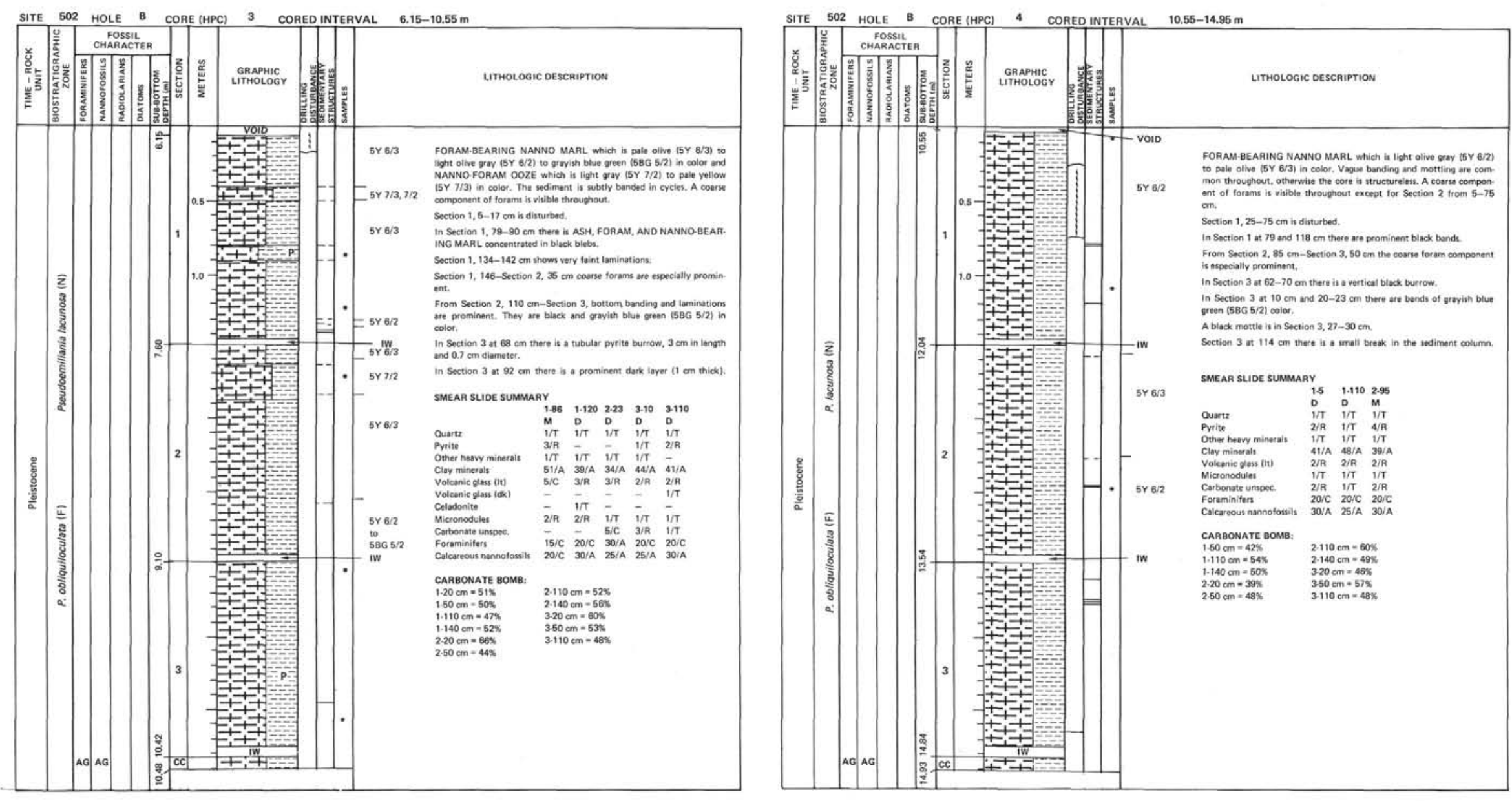

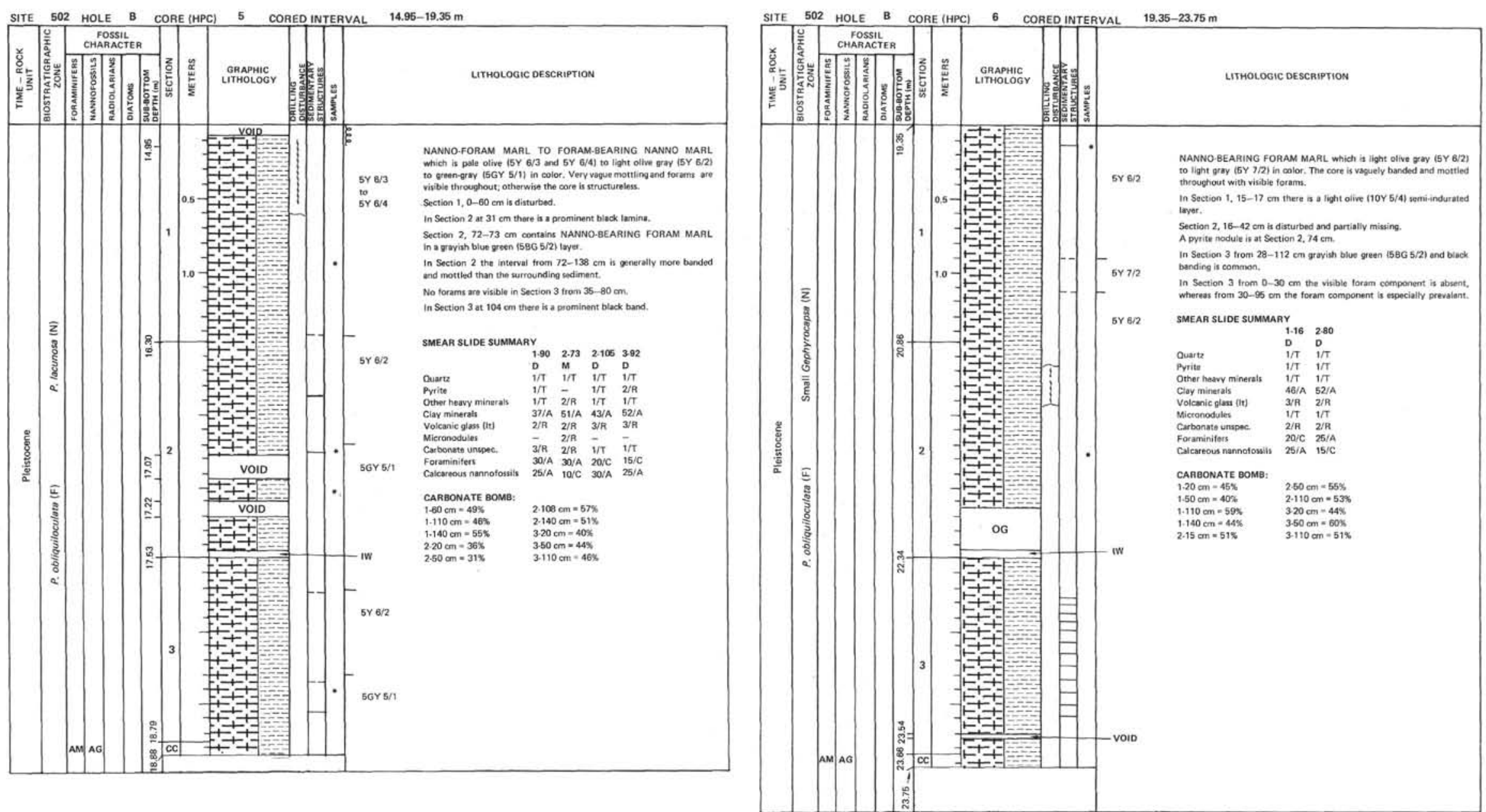

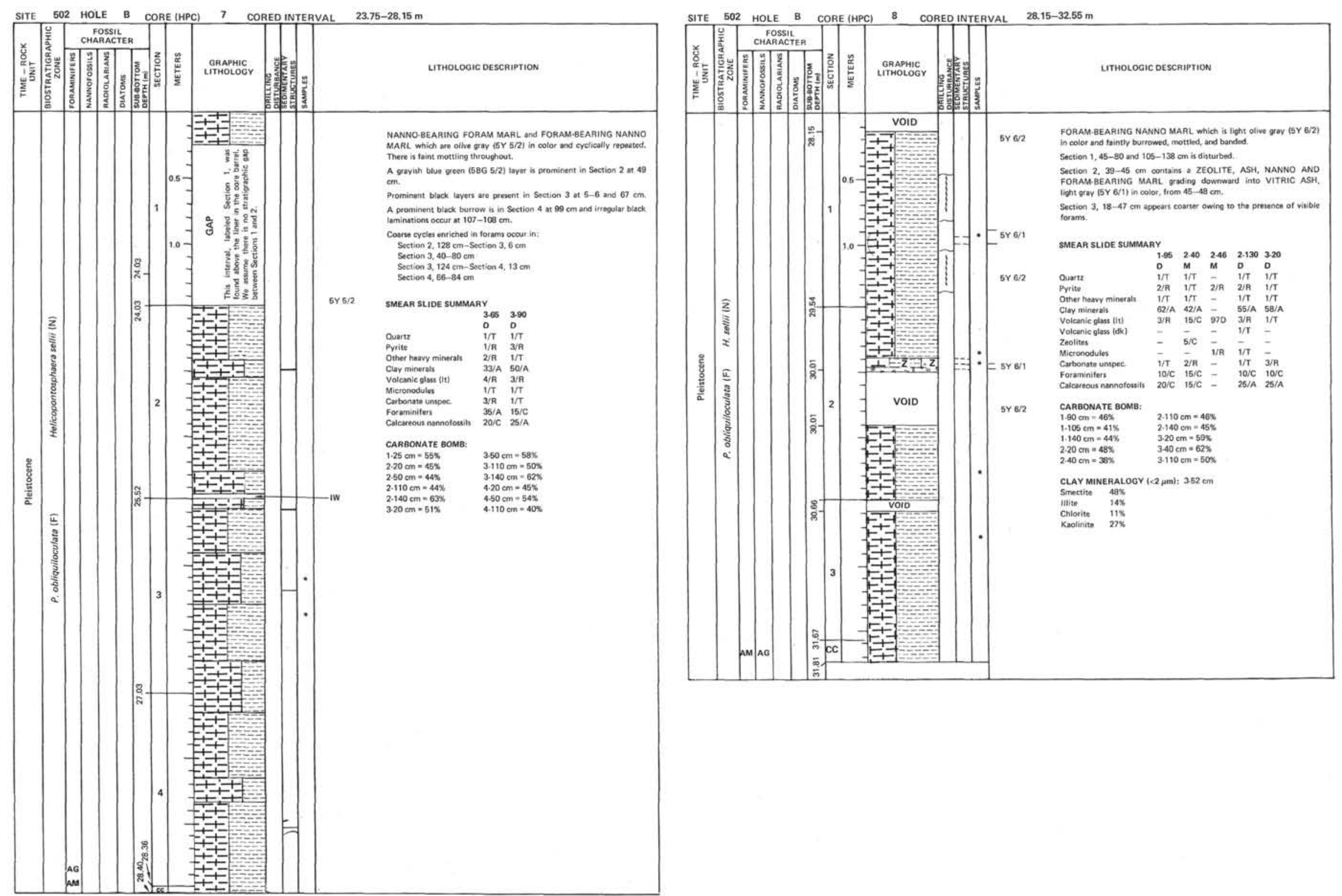

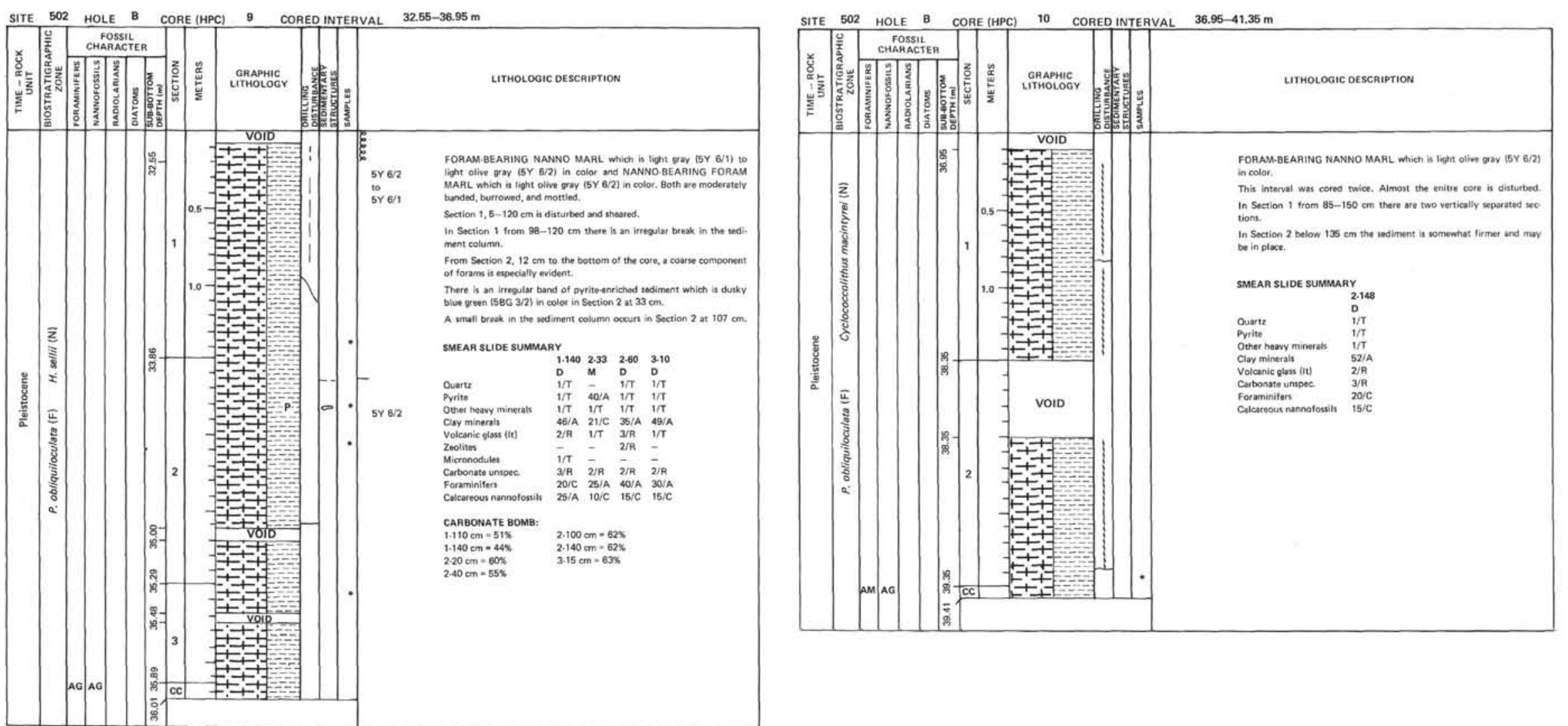

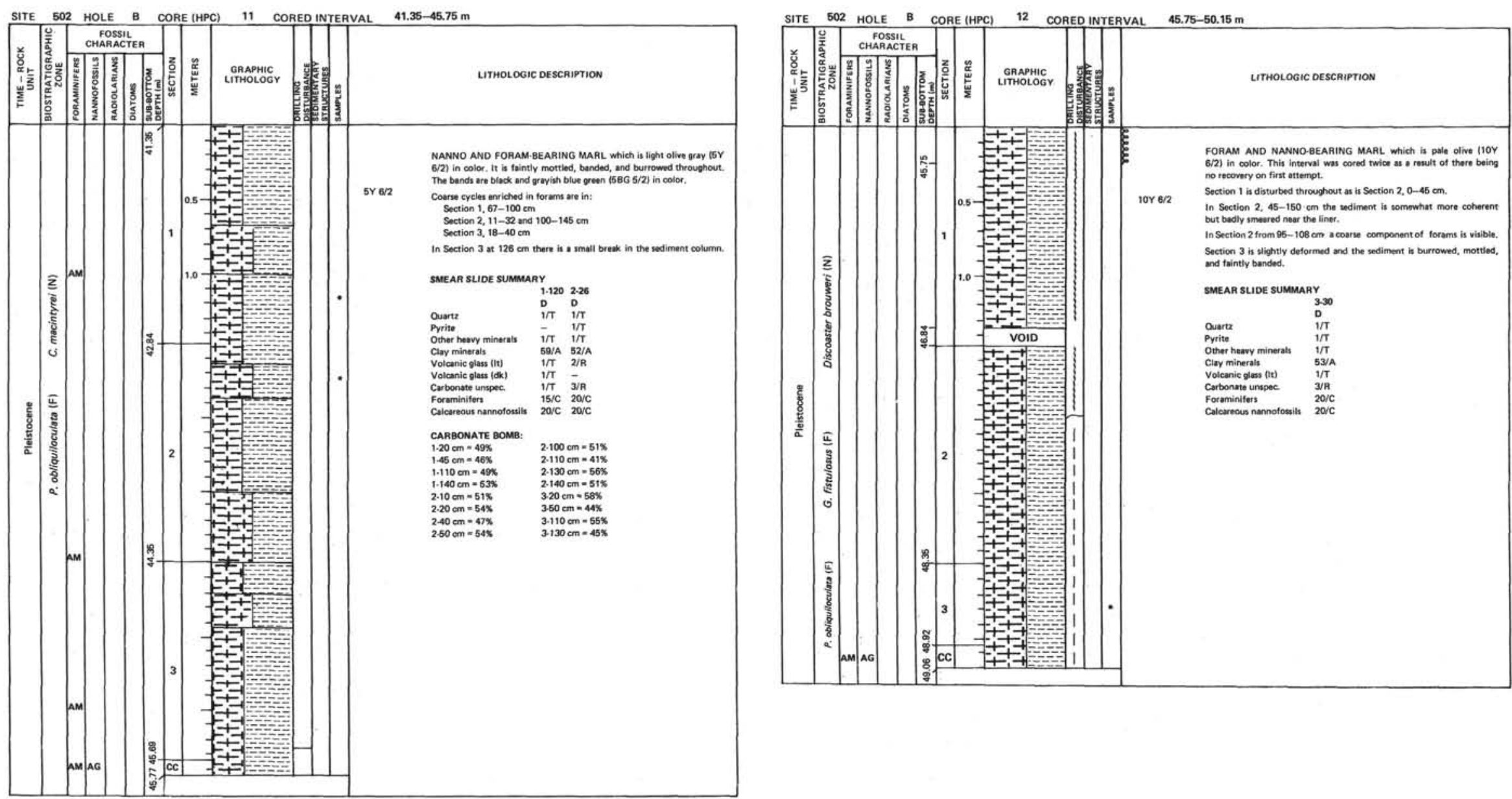

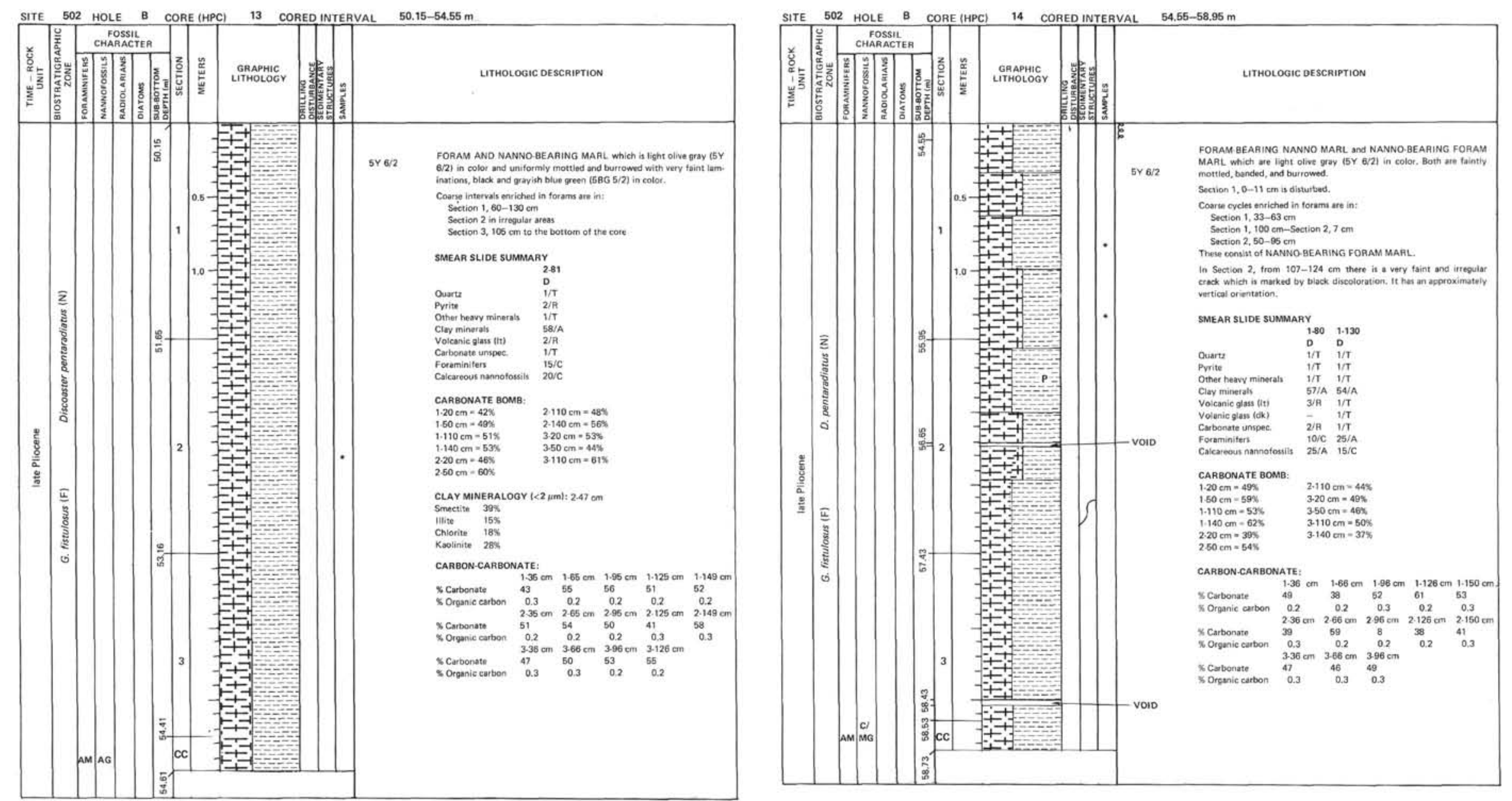

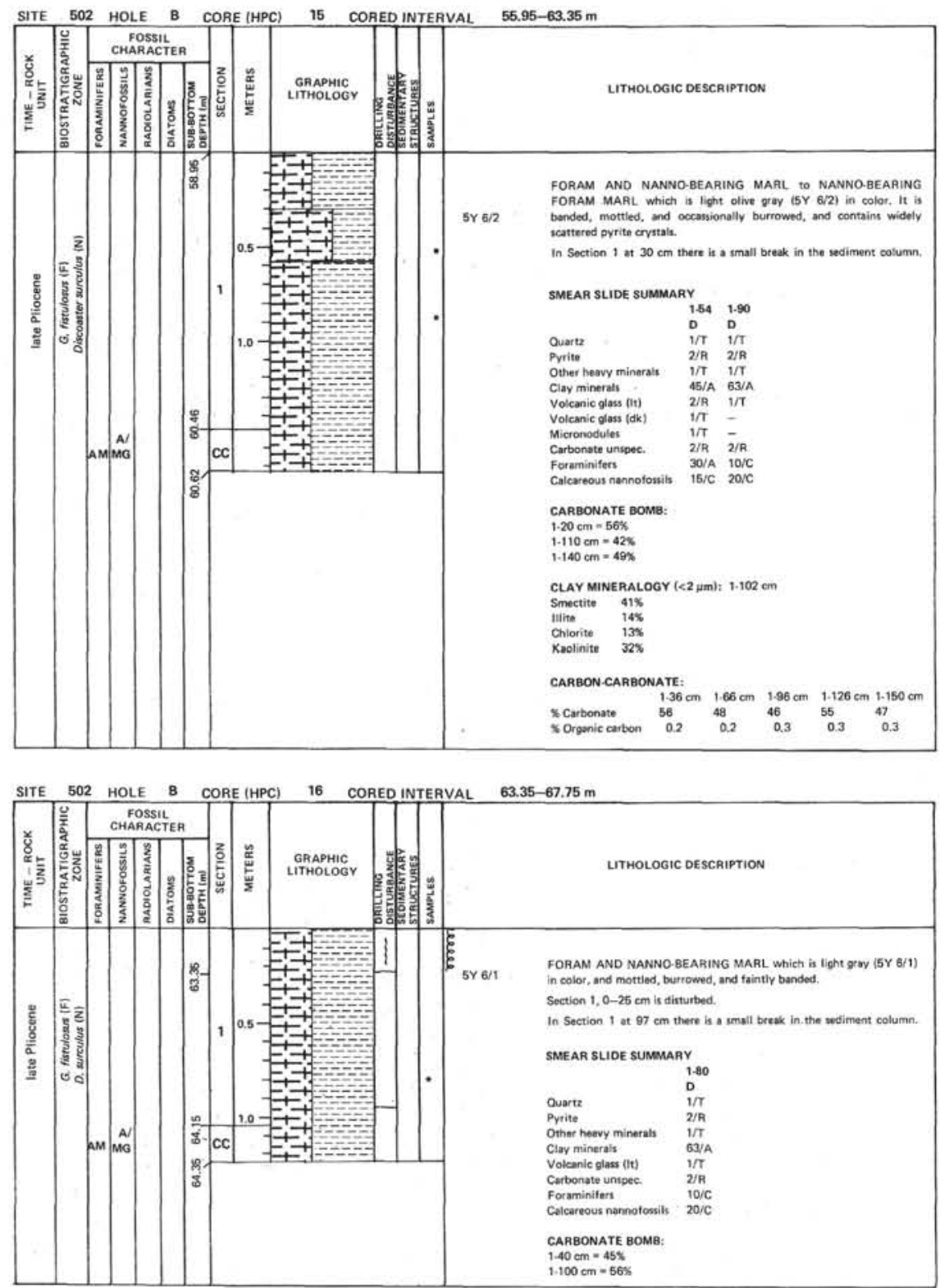

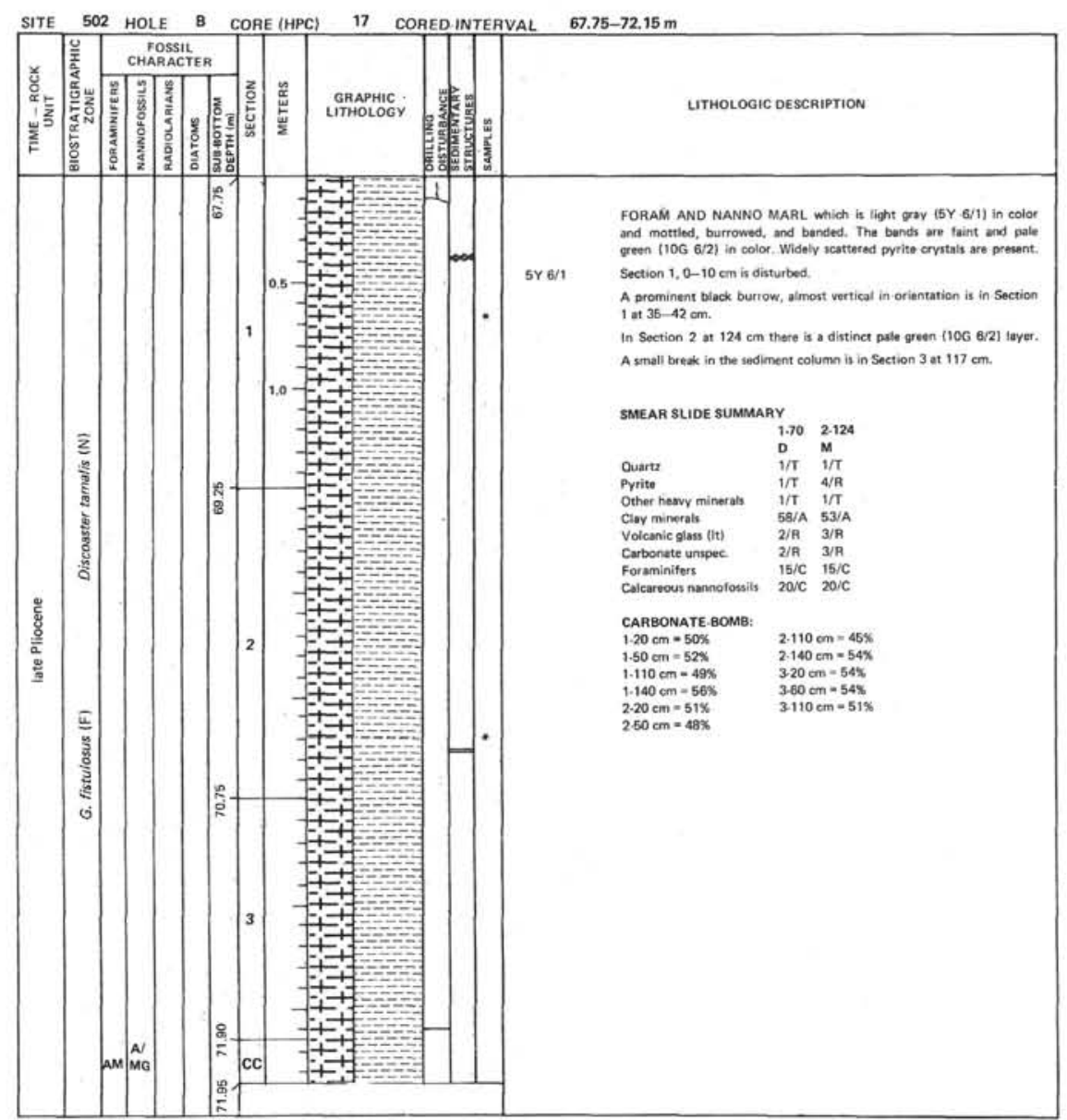



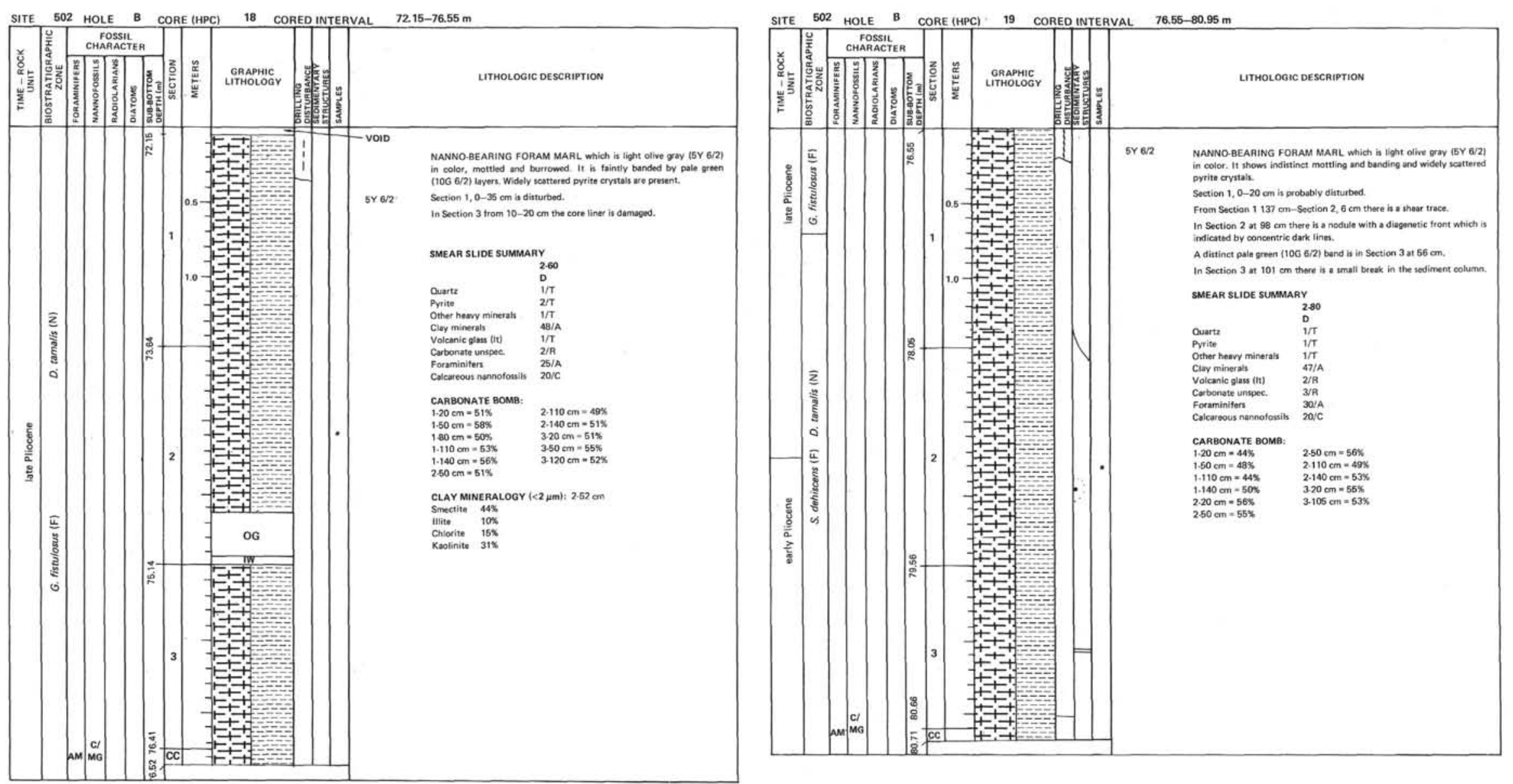

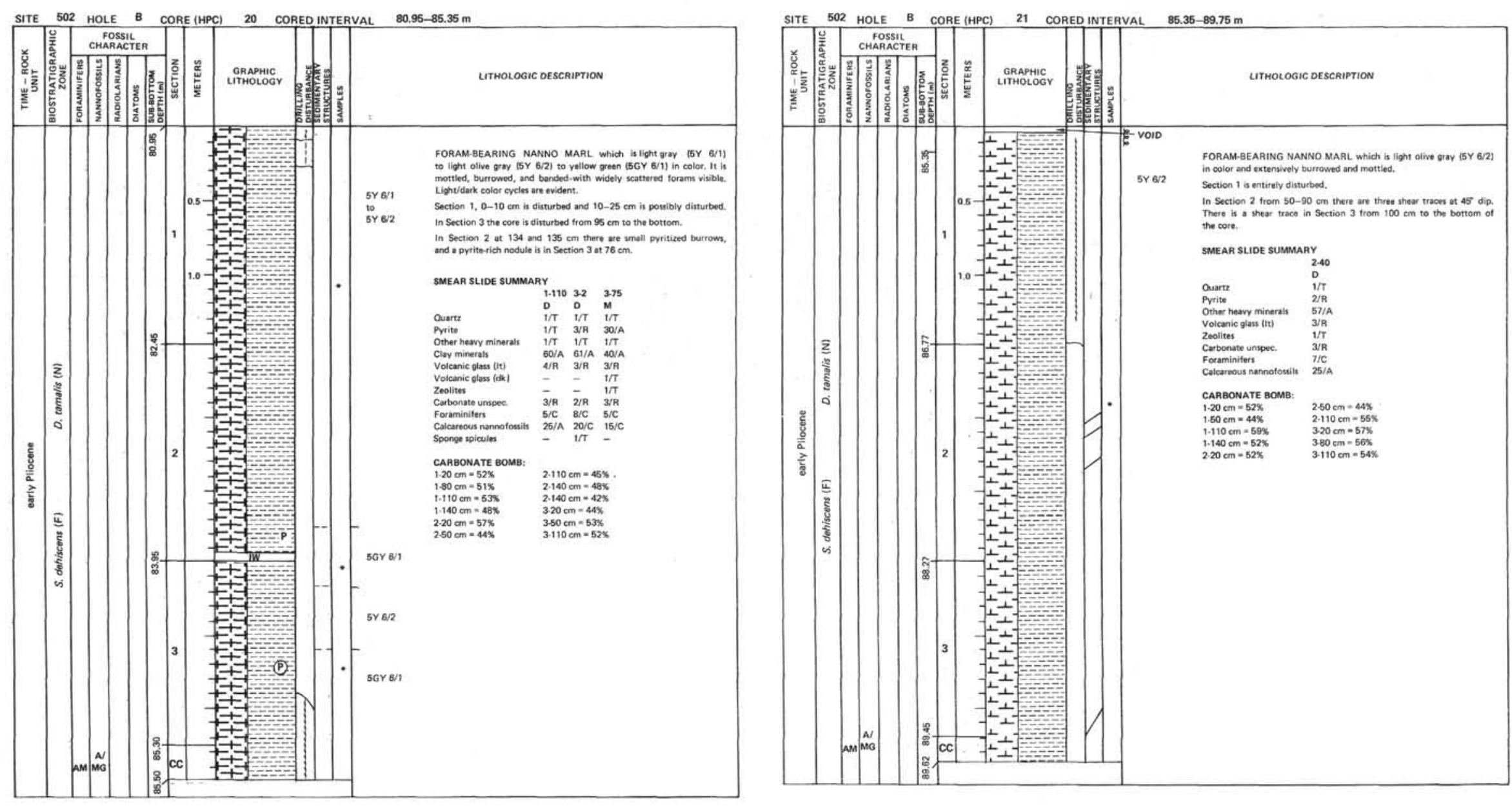

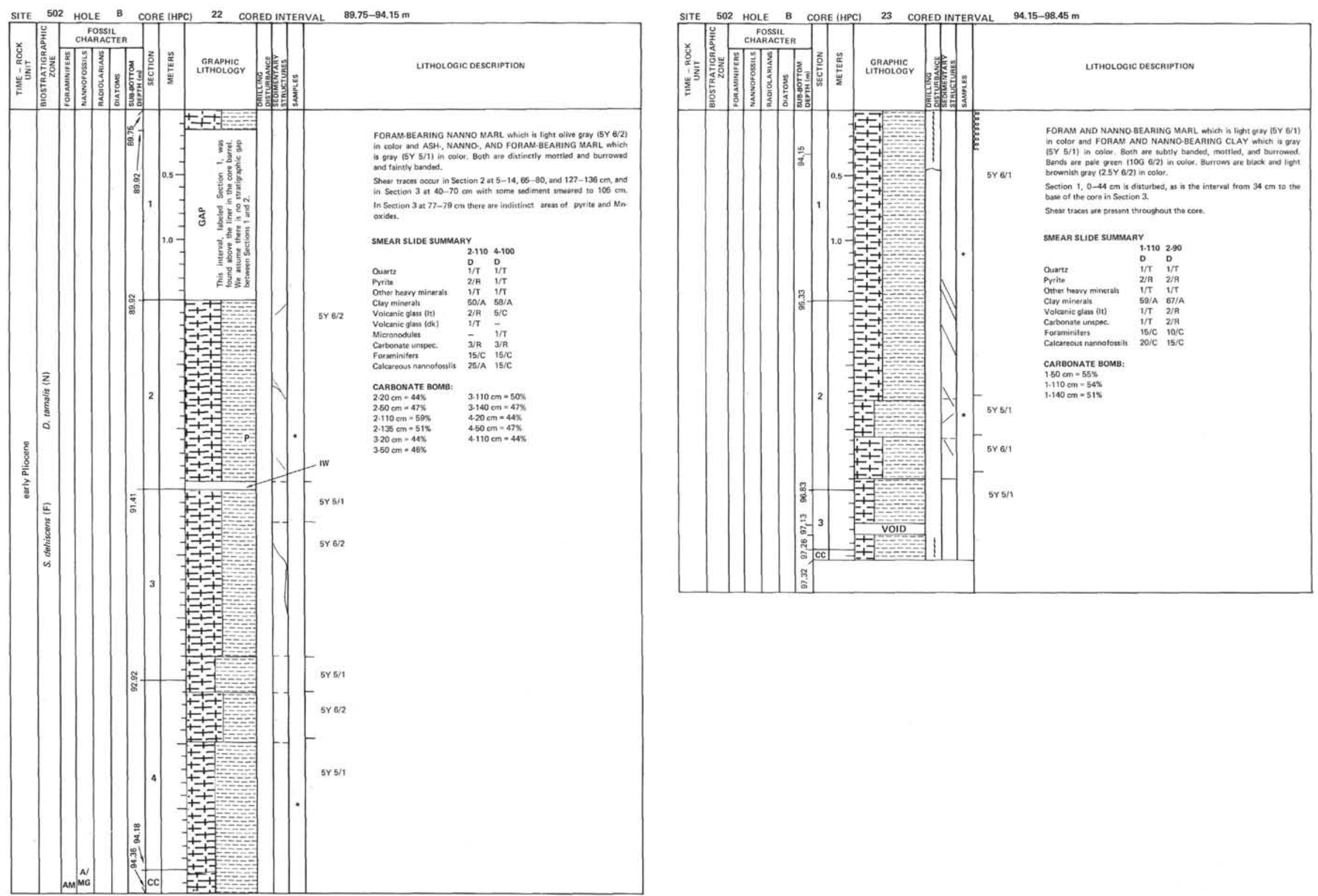

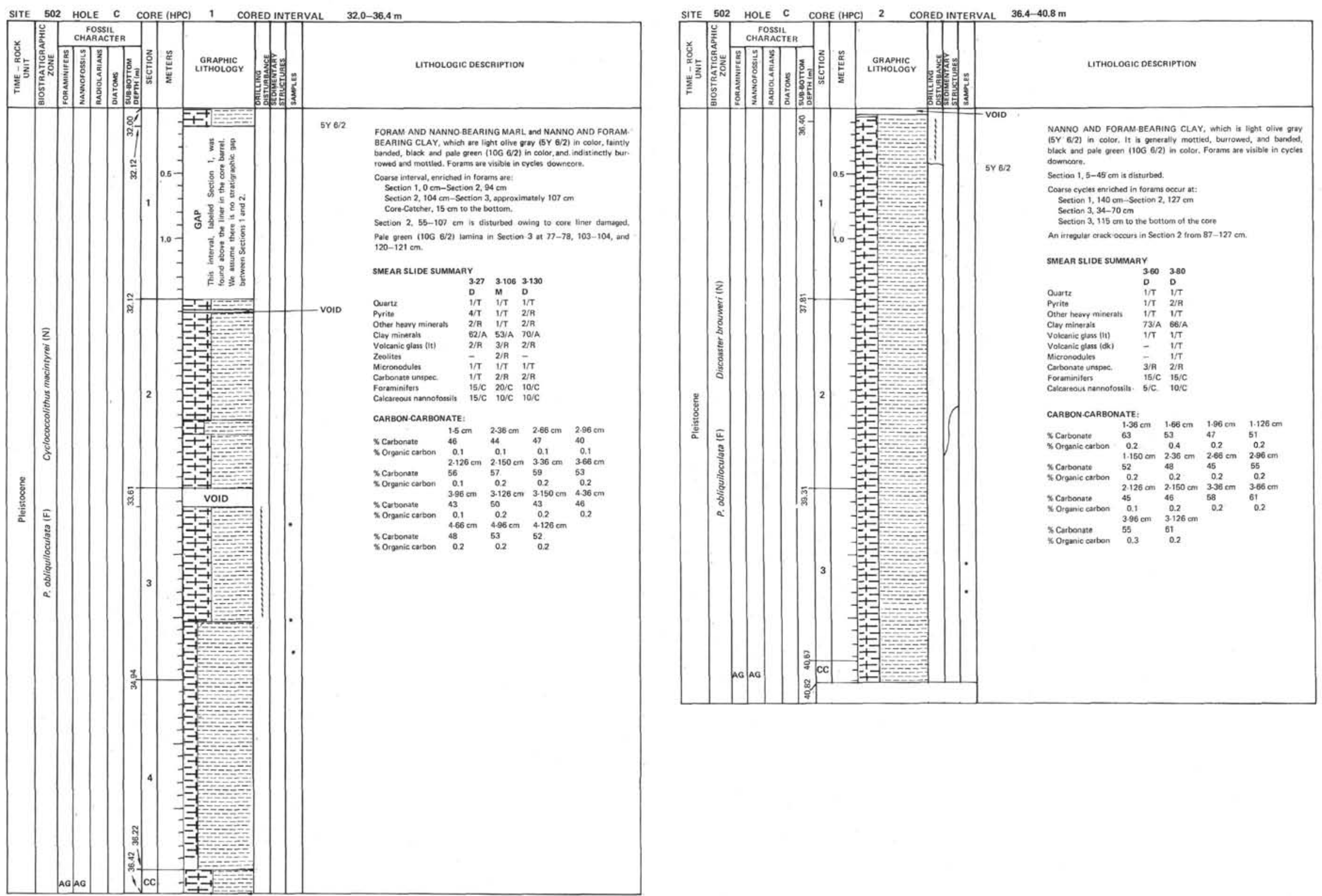

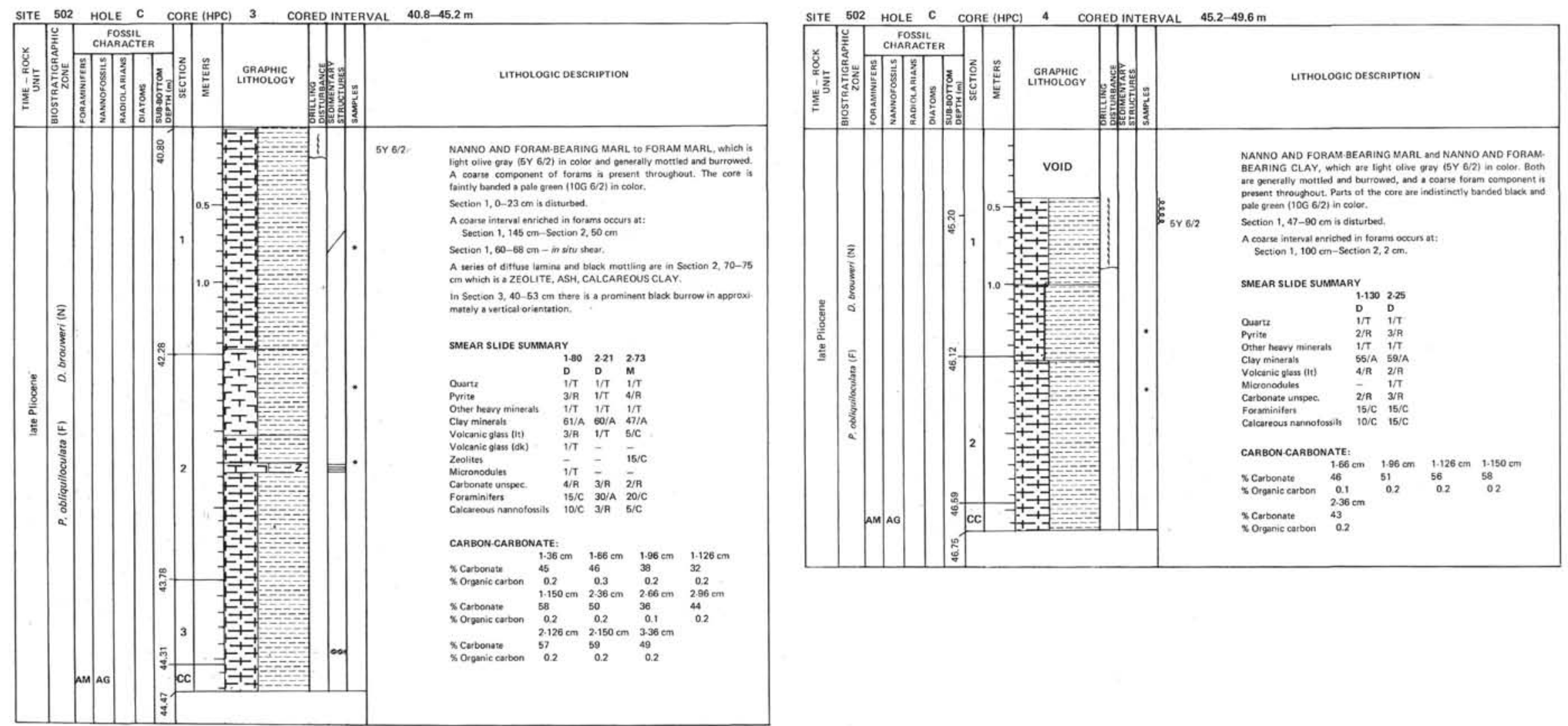

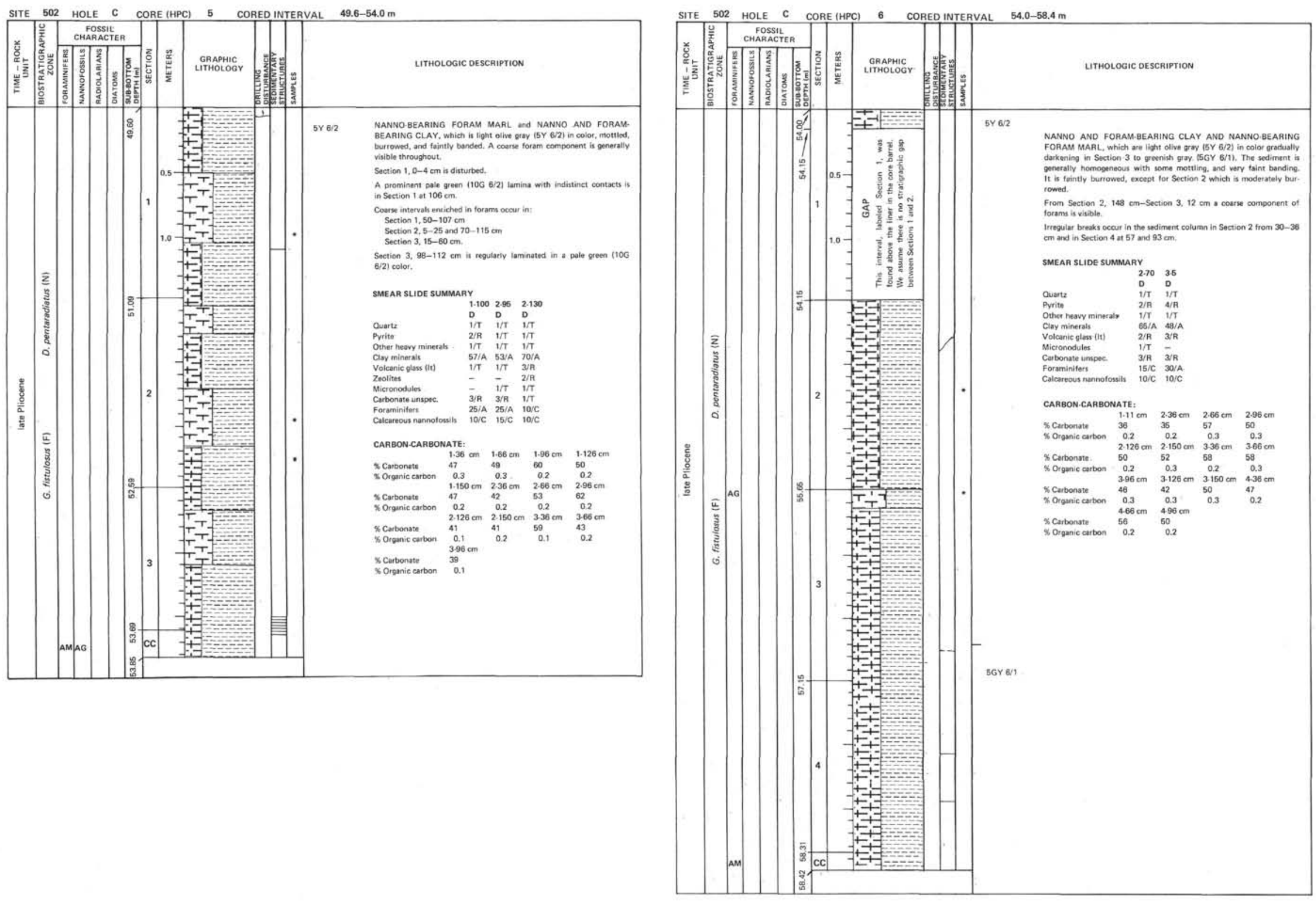


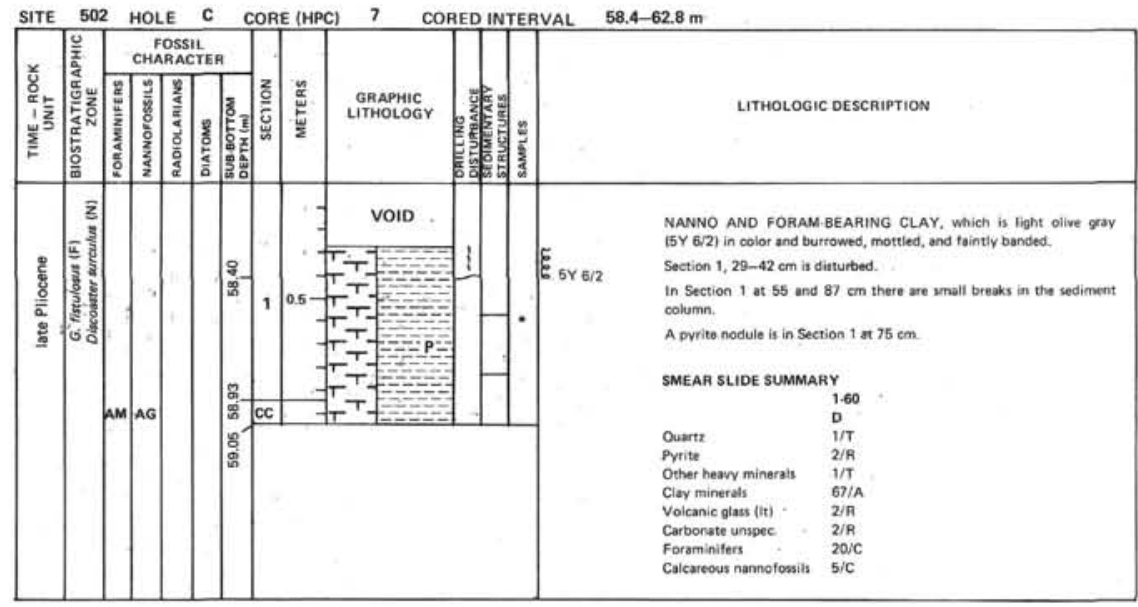

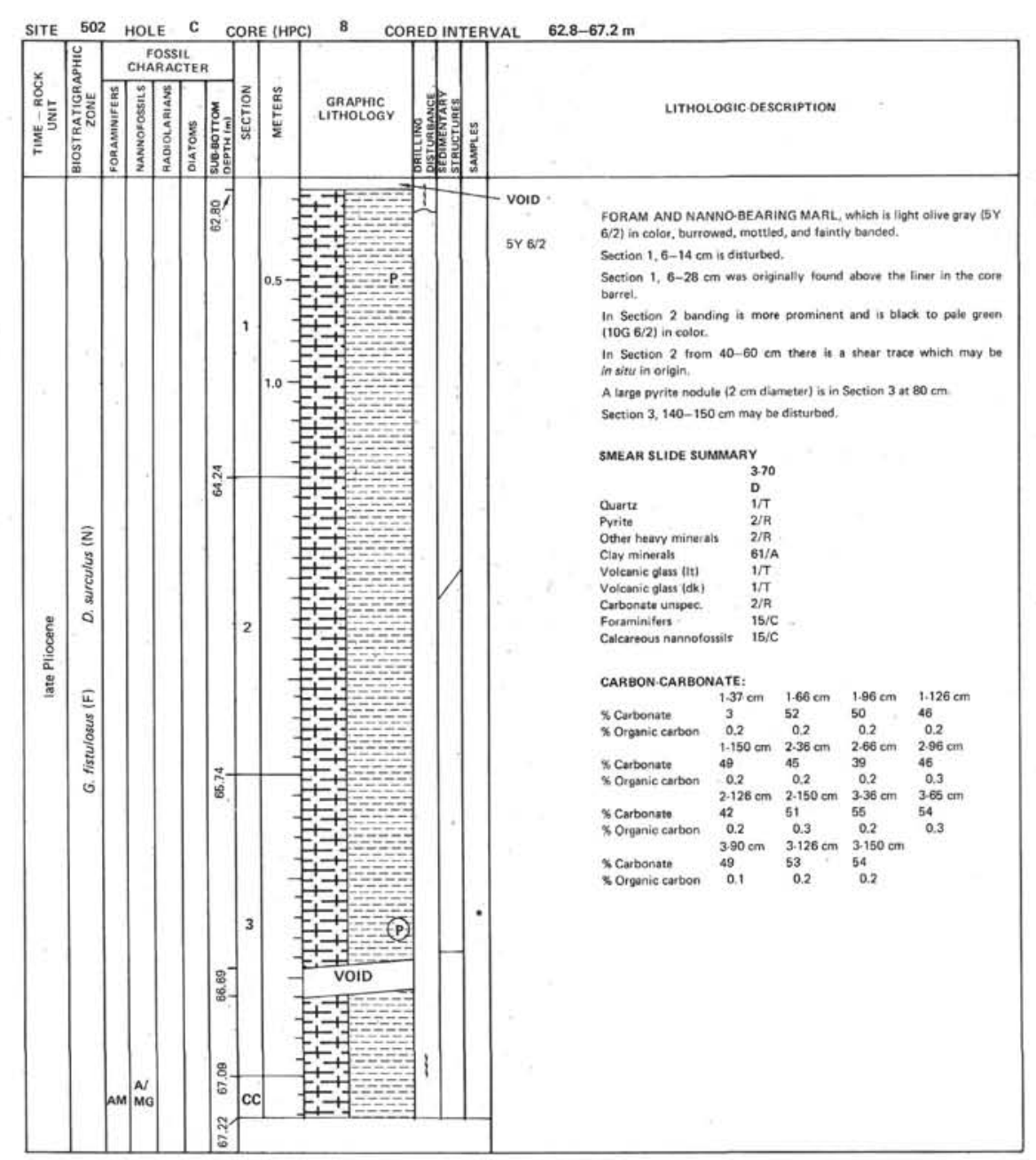



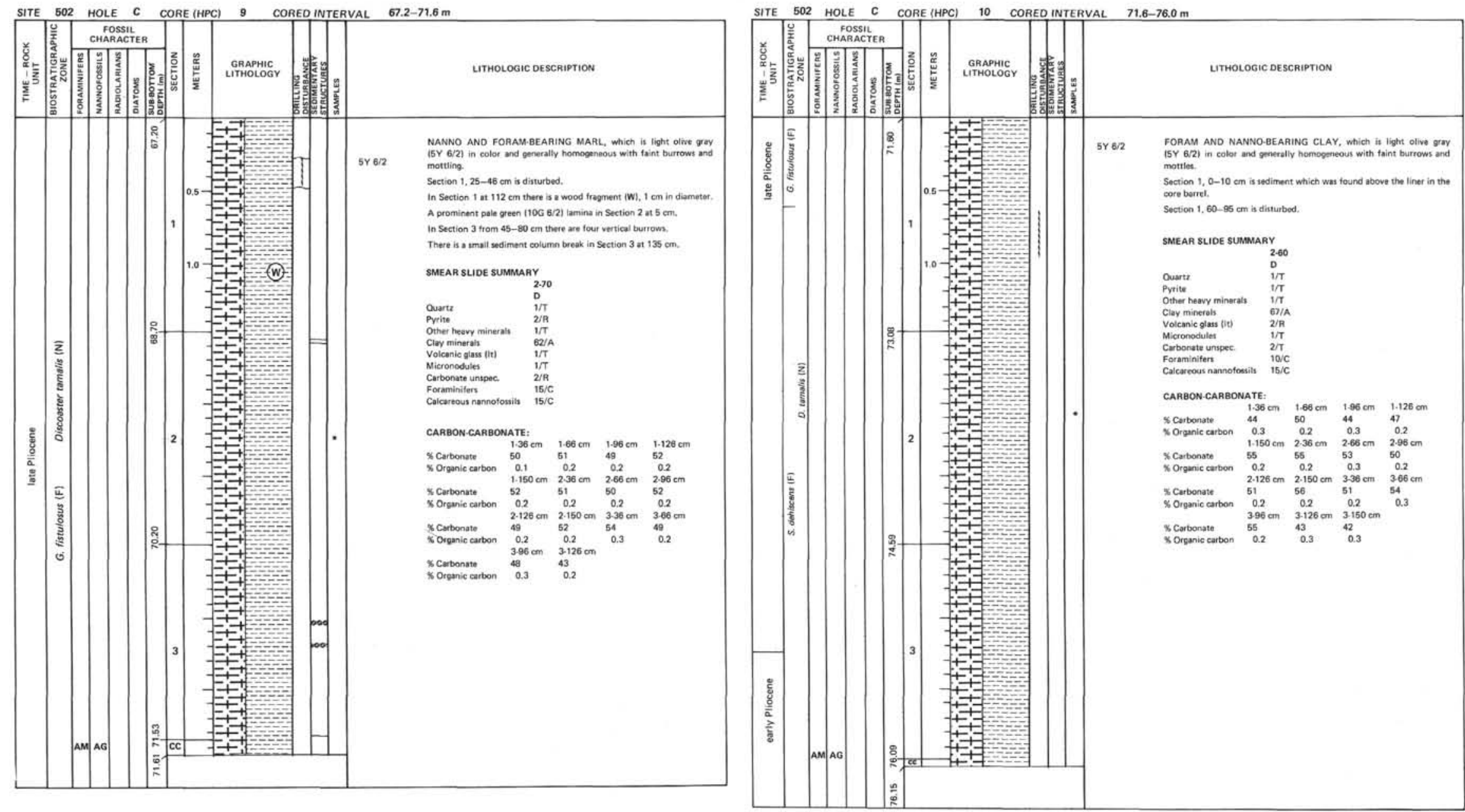

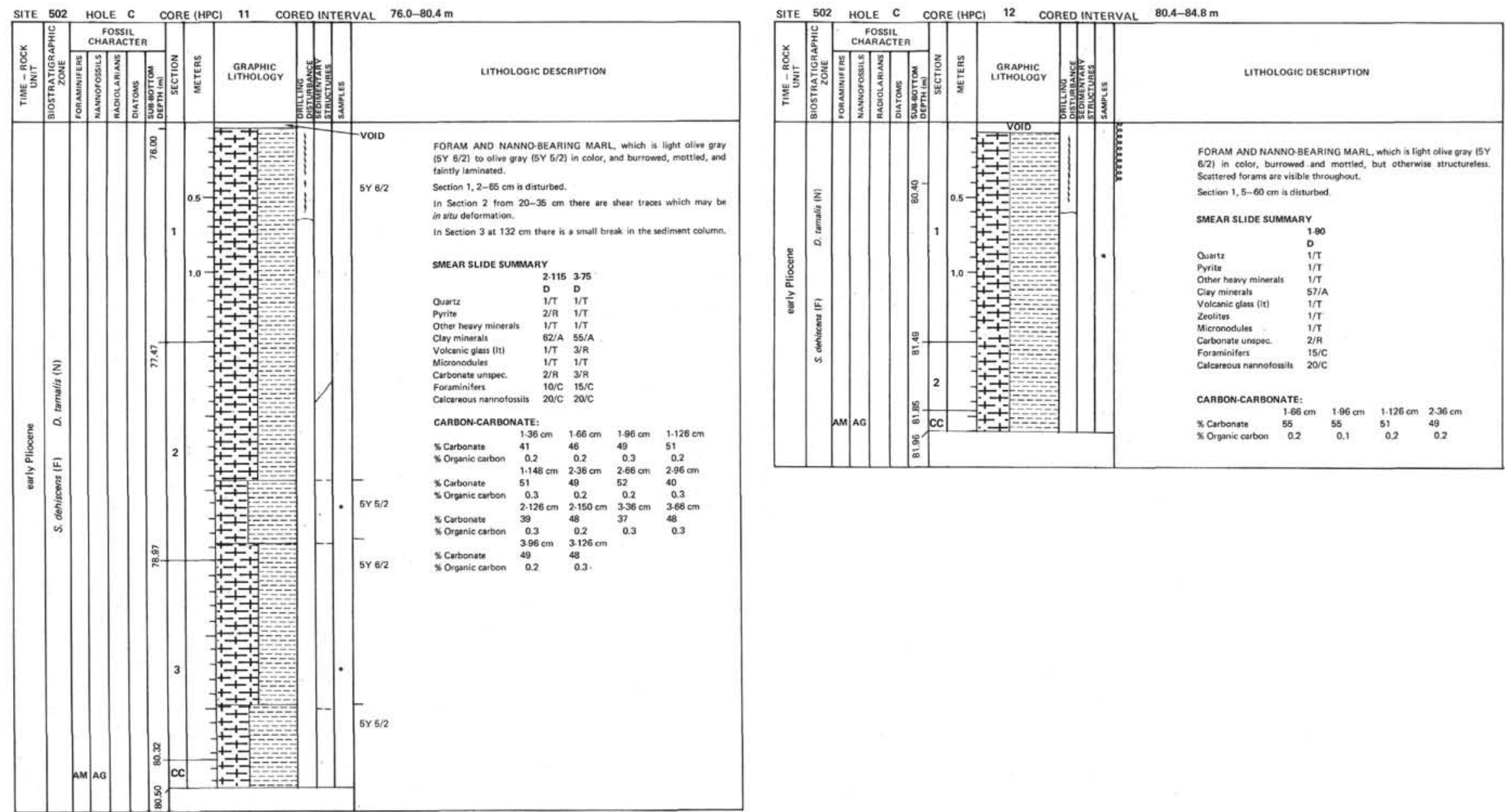

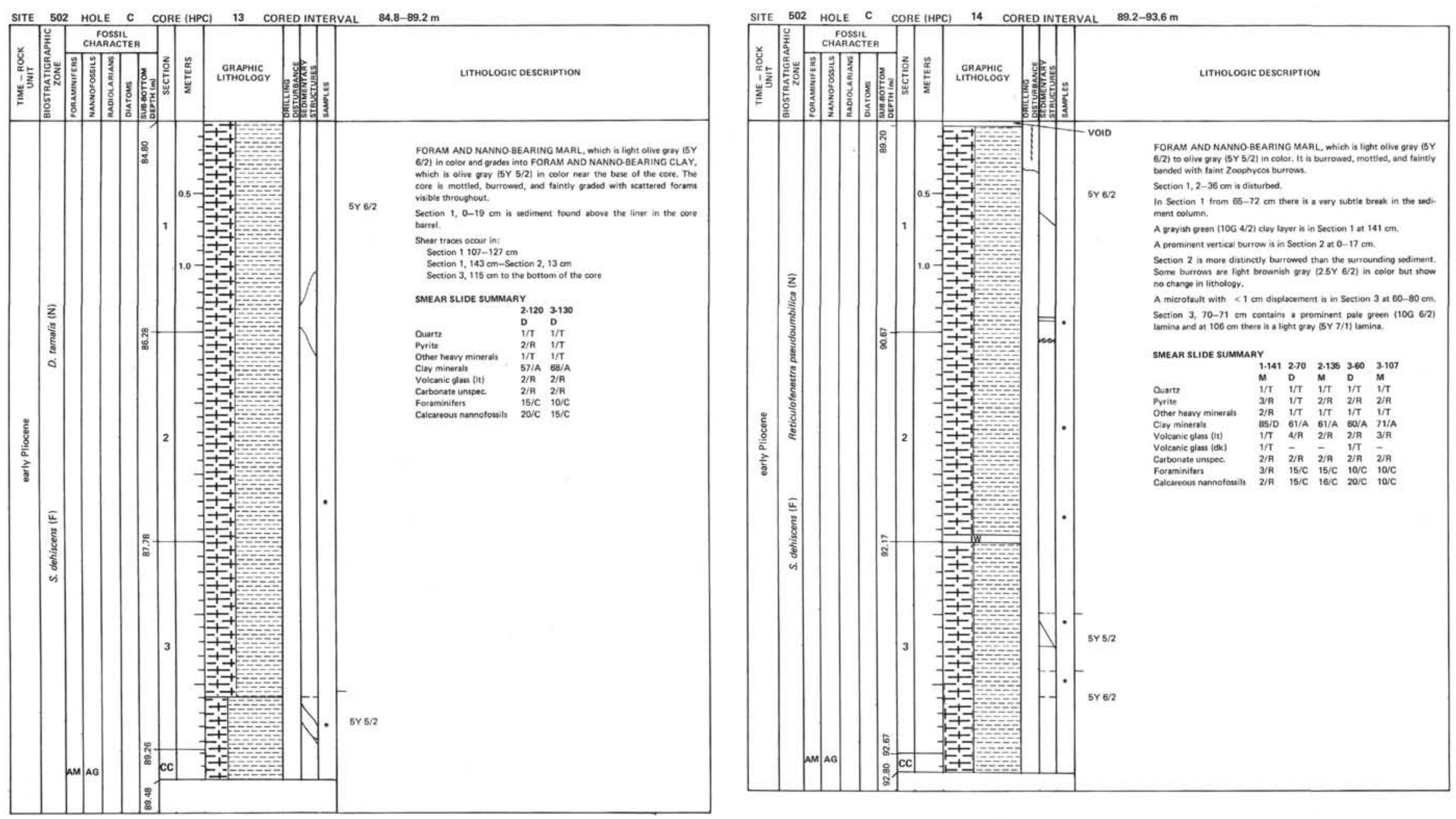

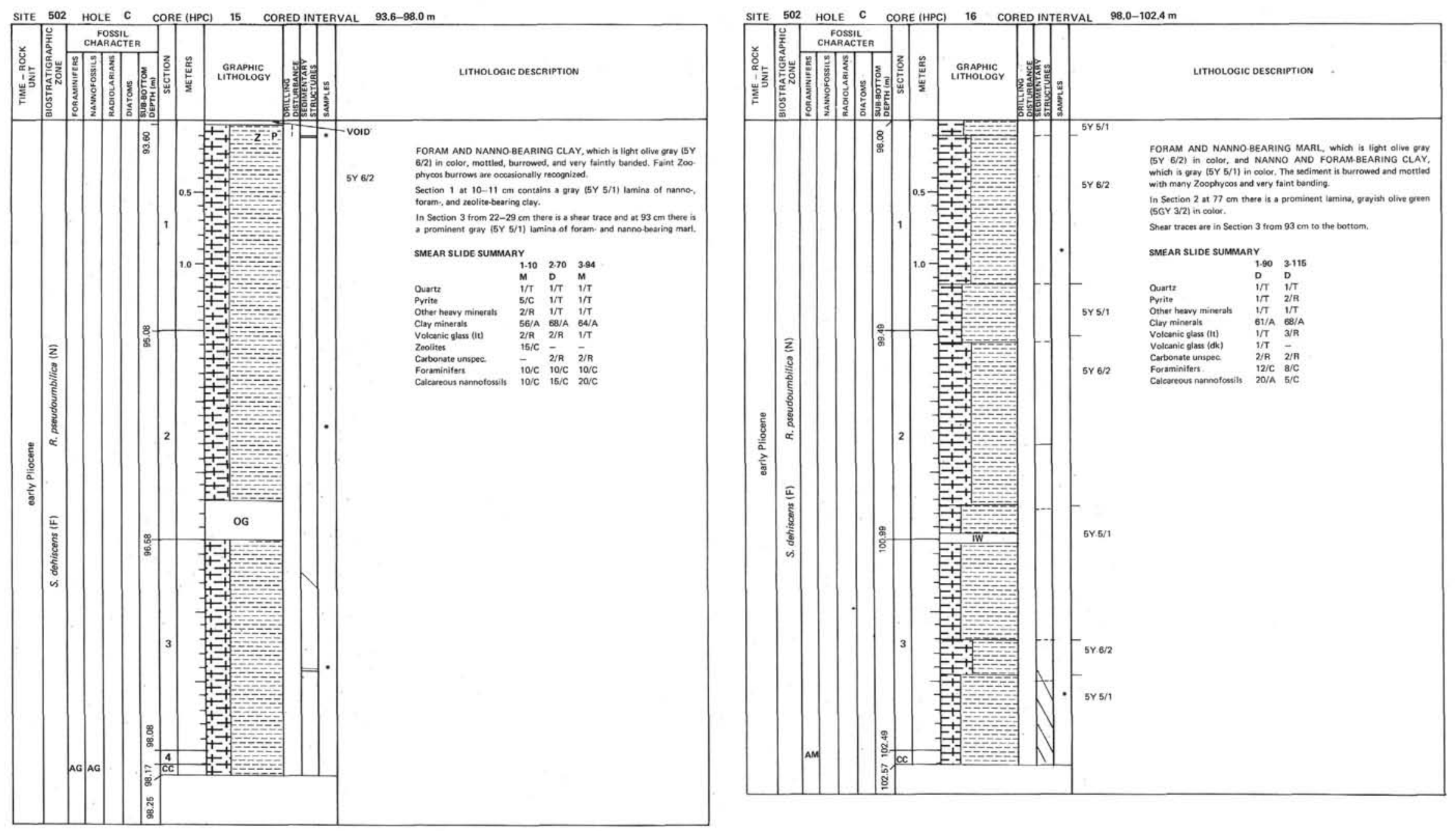

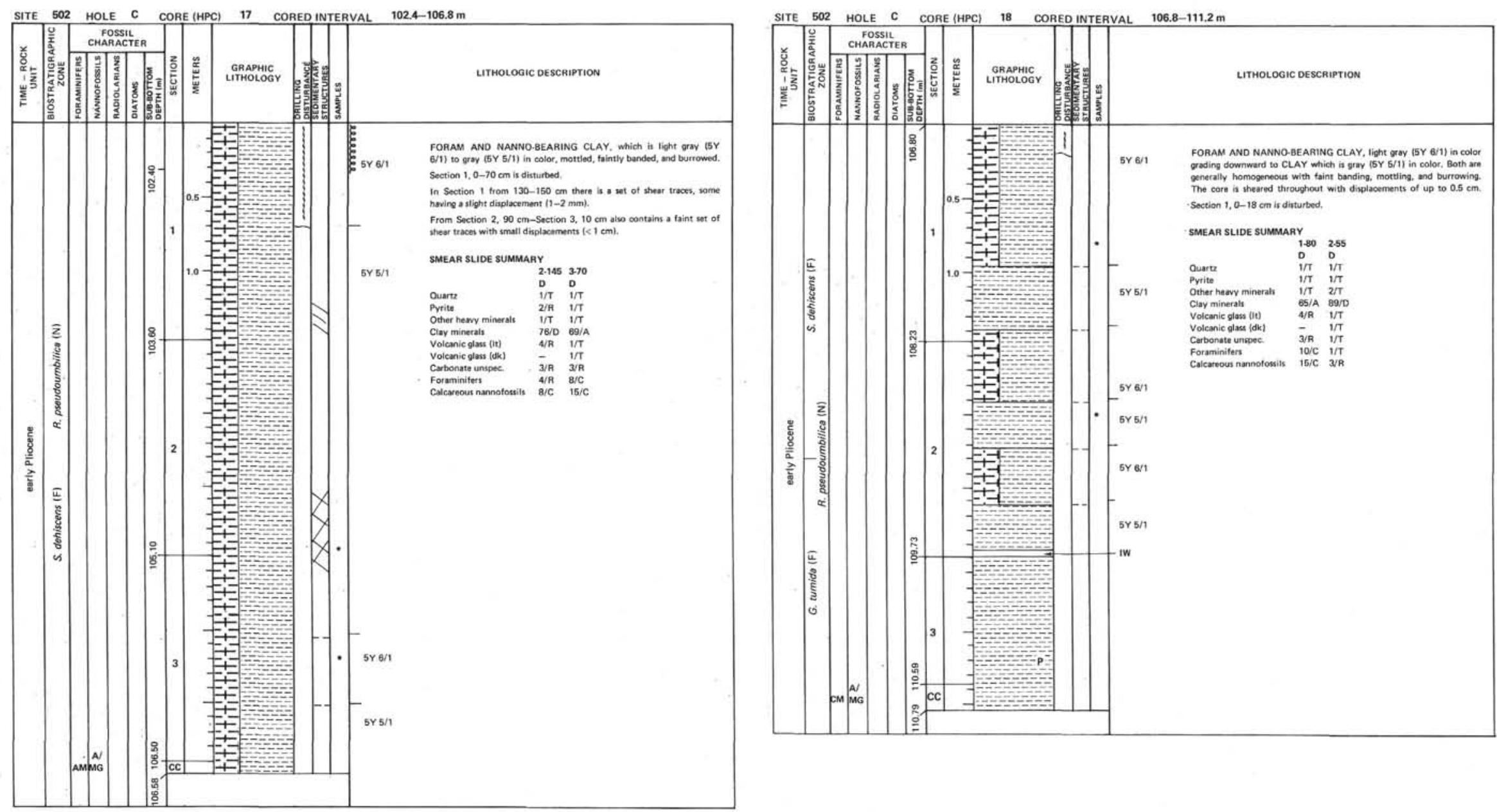

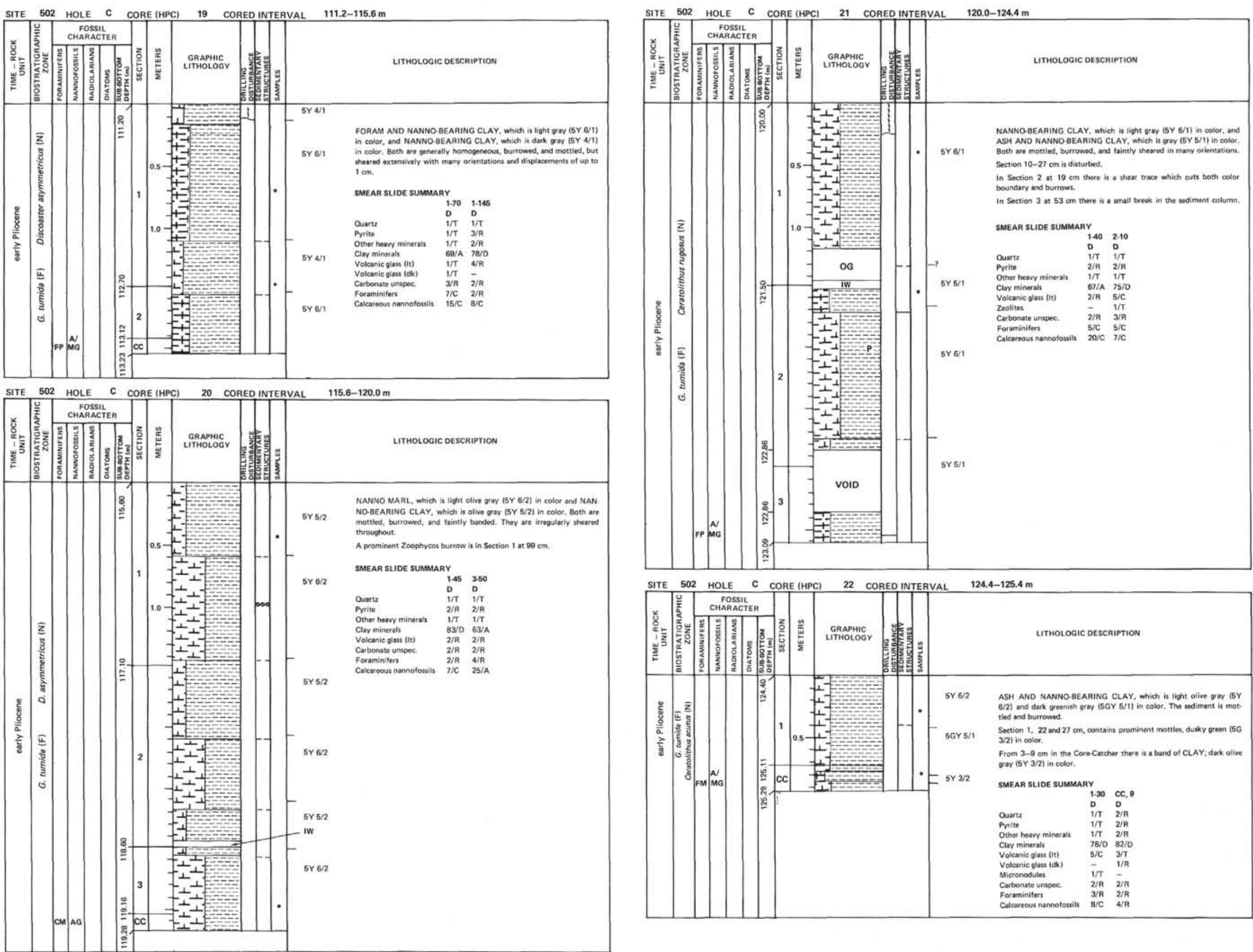


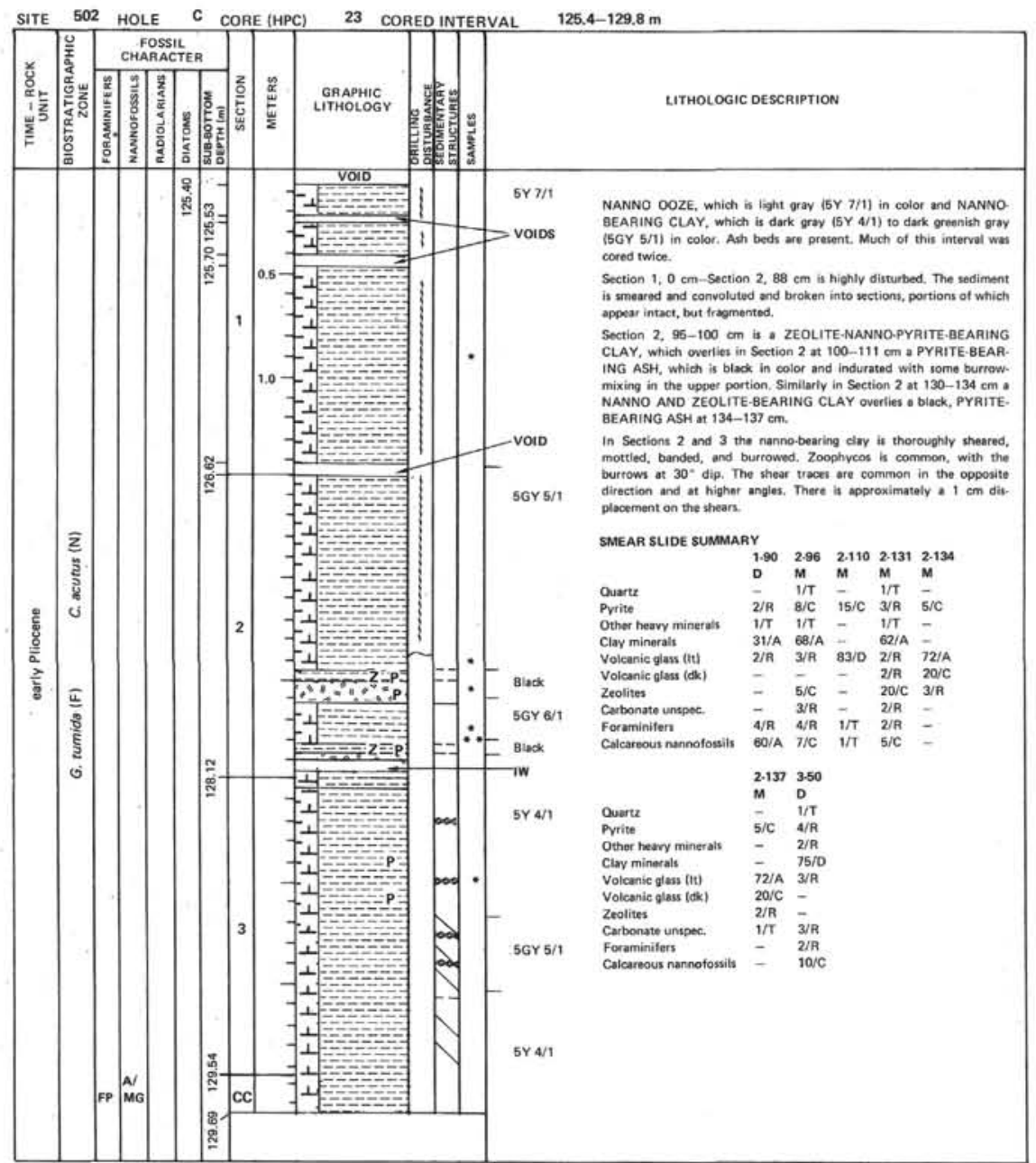

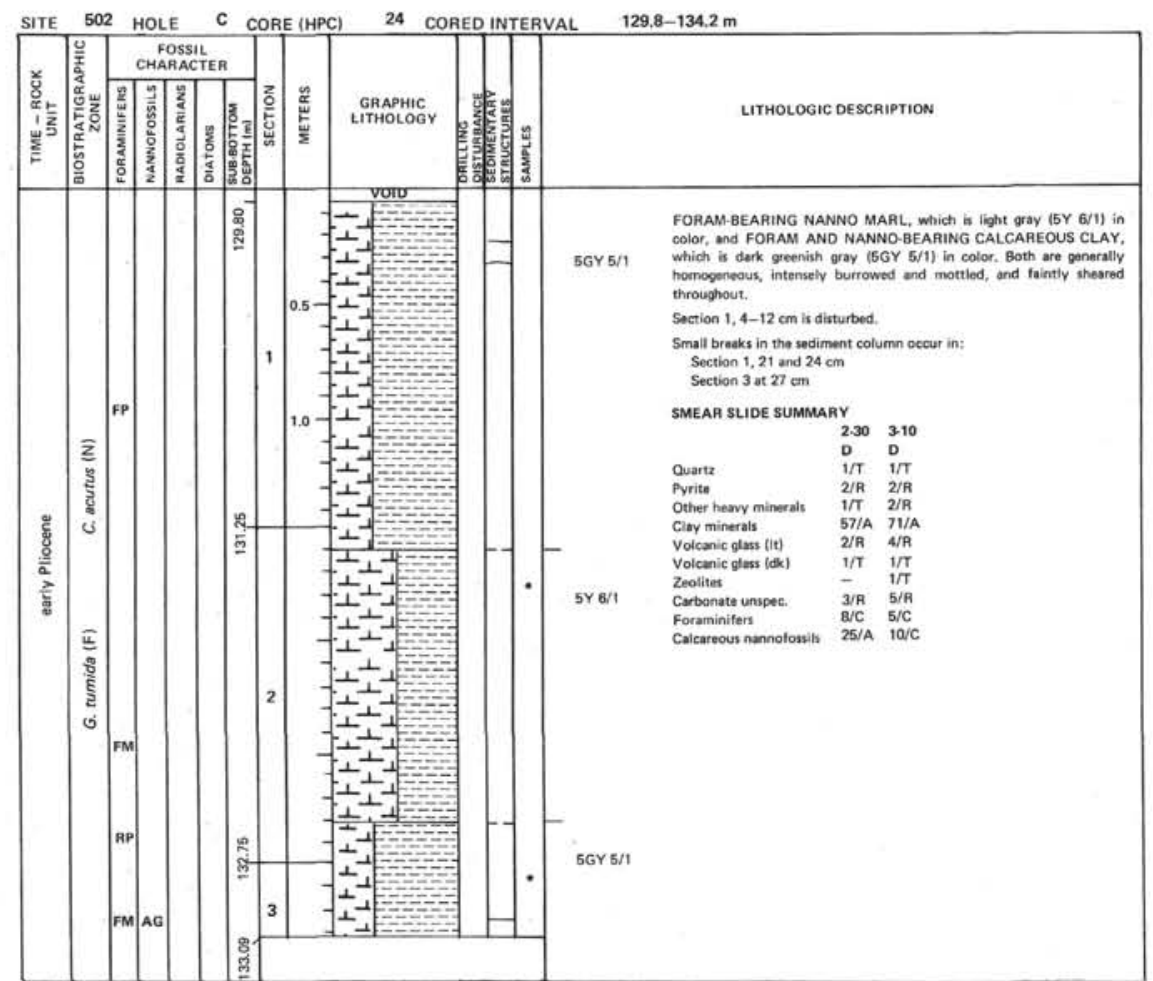

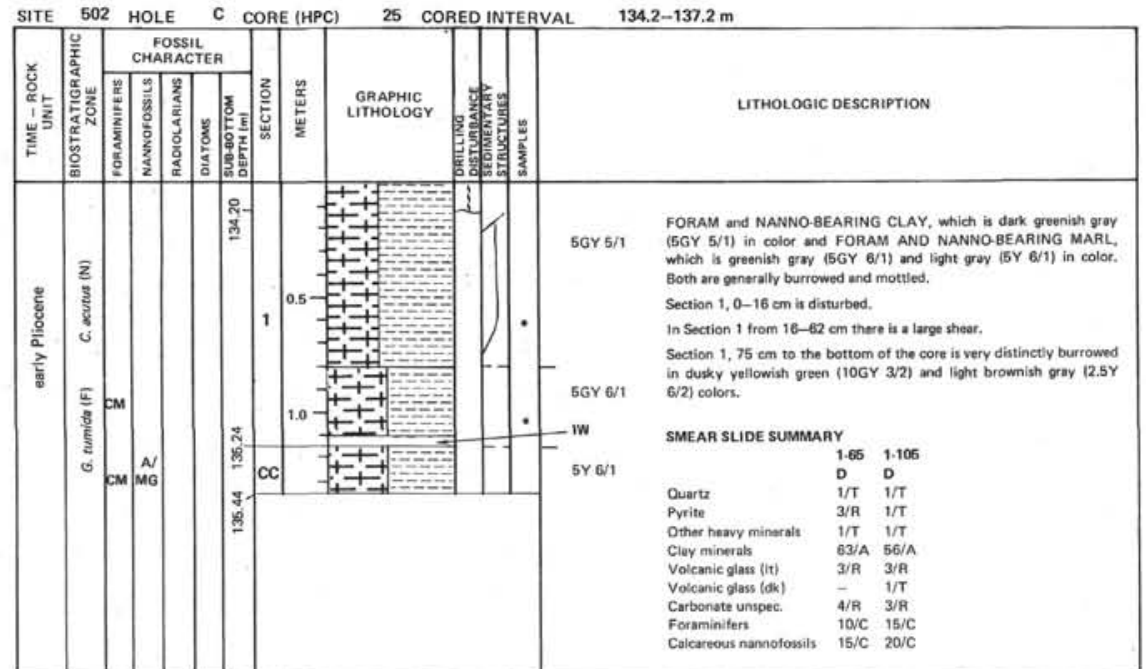



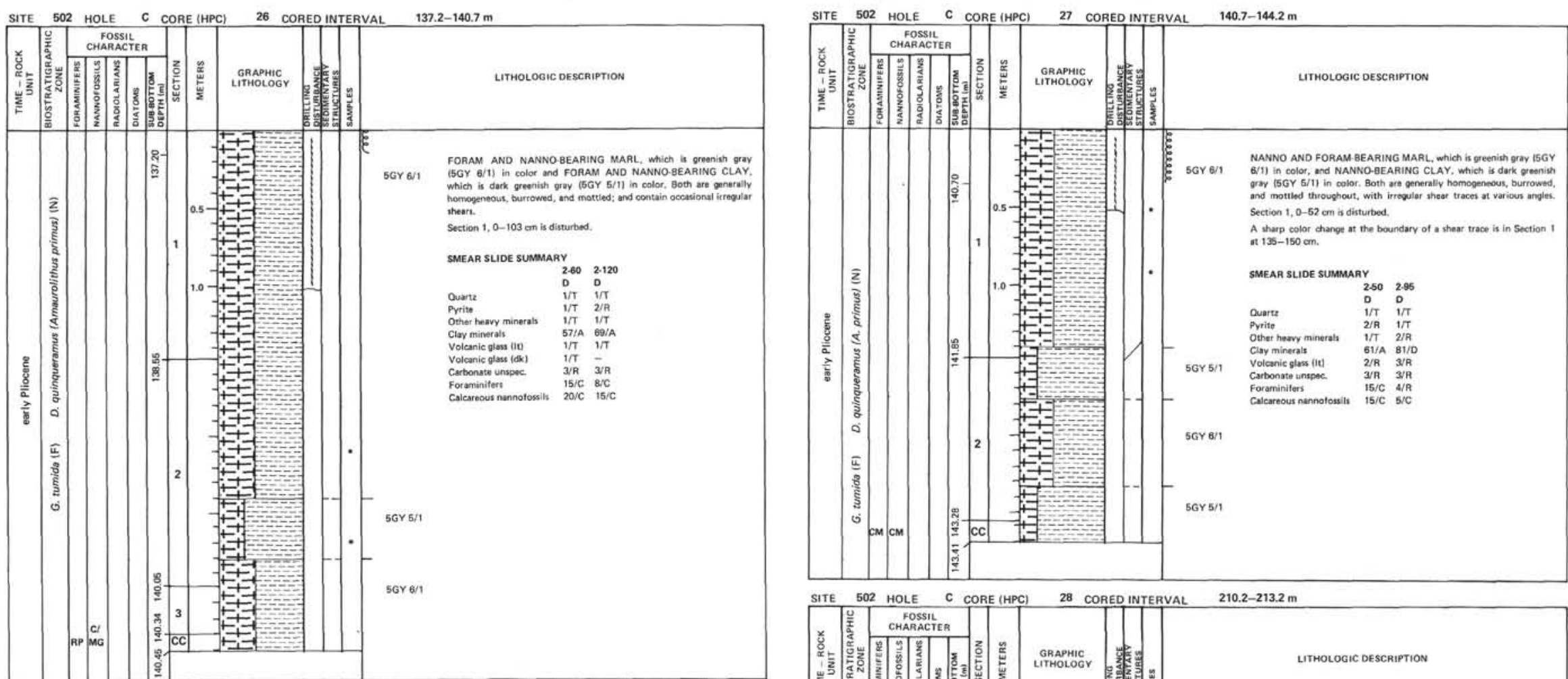

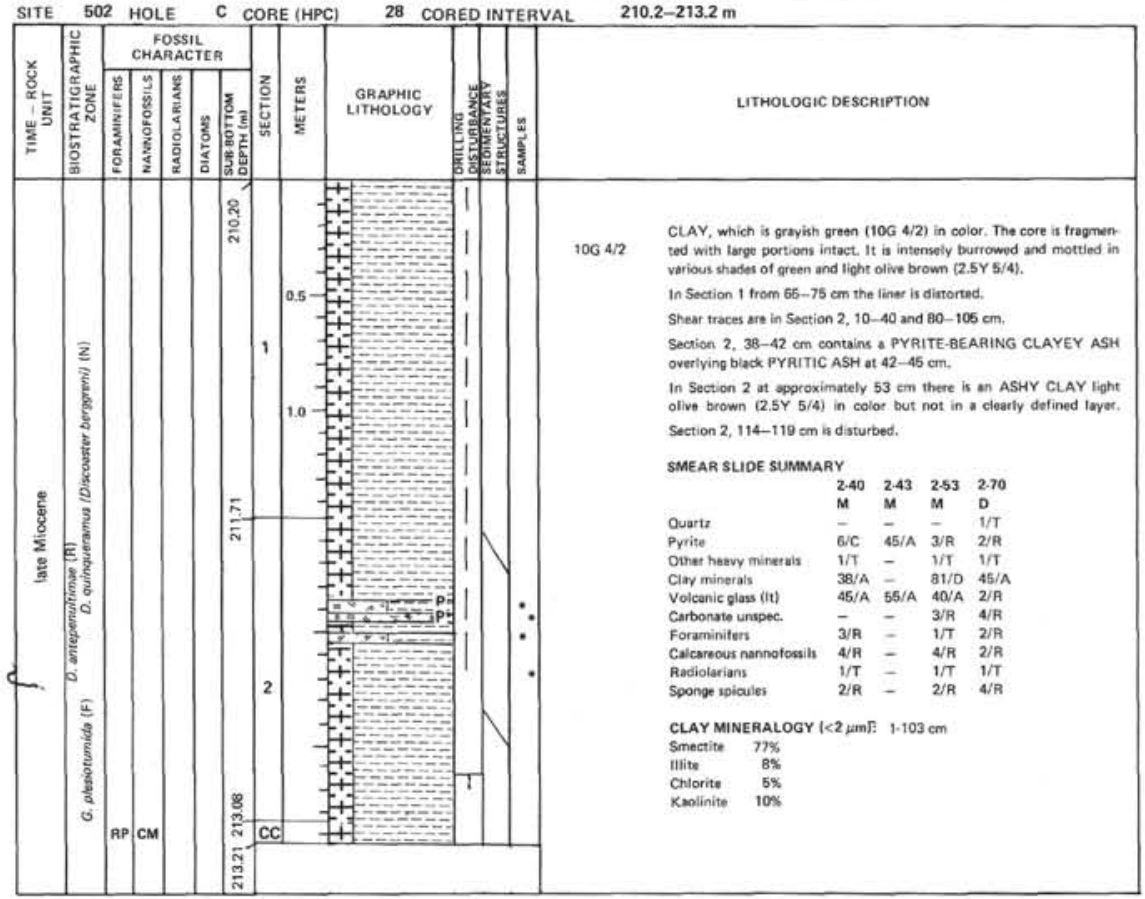




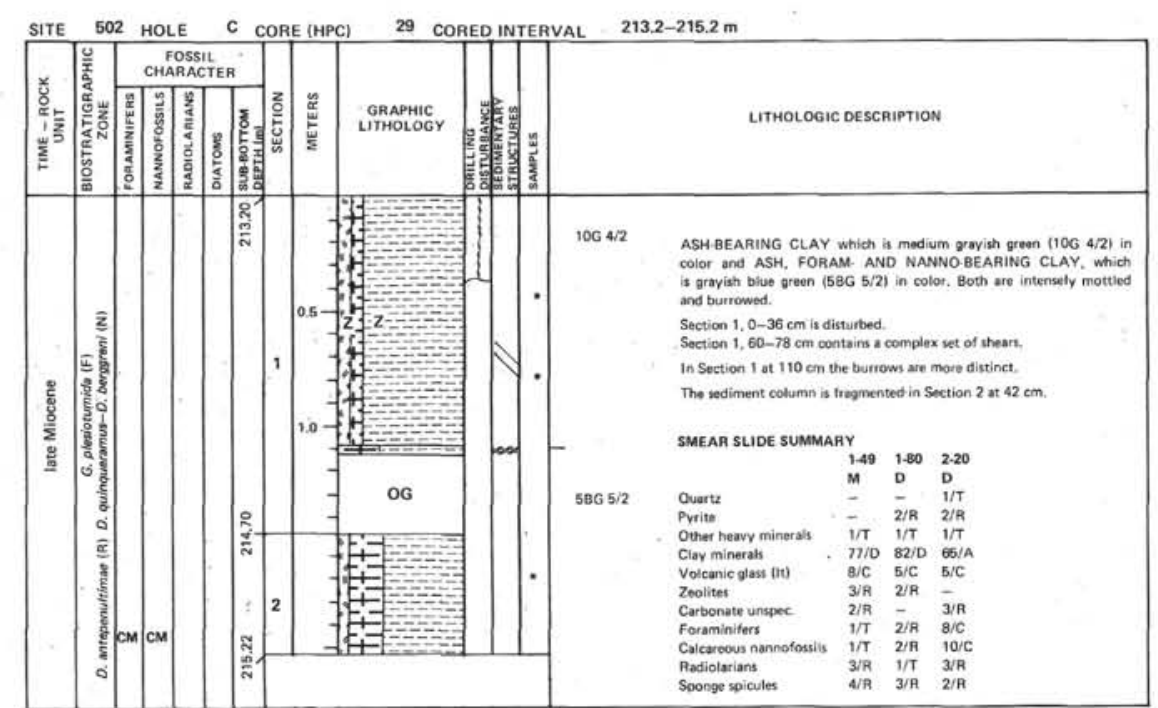

SITE 502 HOLE C CORE (HPC) 30 CORED INTERVAL $215.2-216.7 \mathrm{~m}$

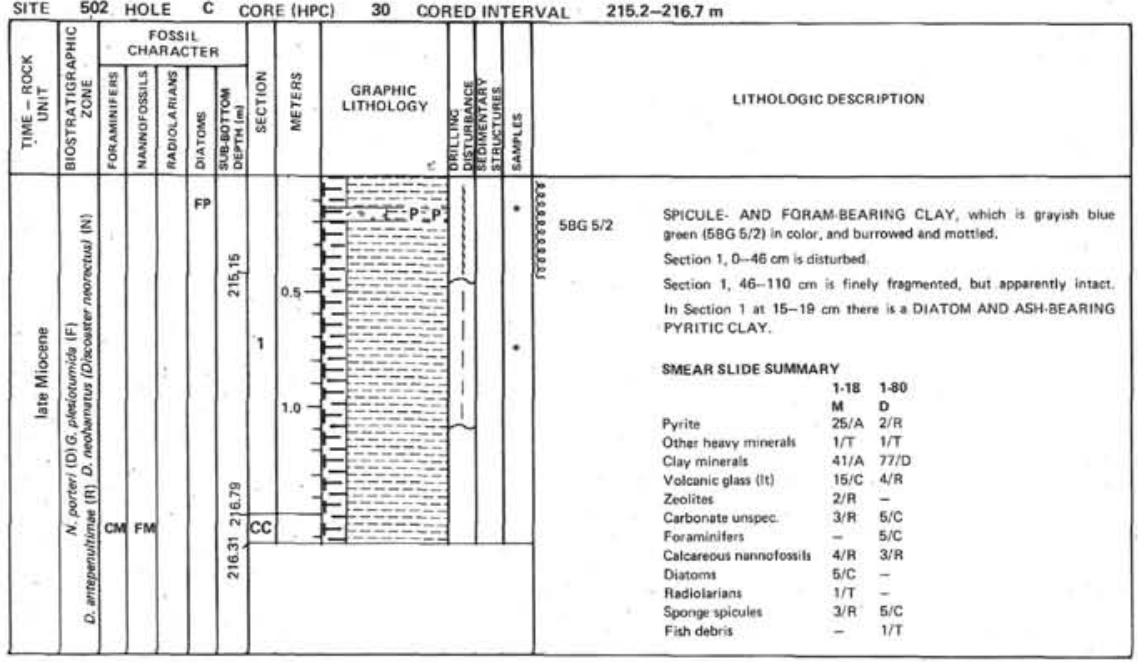
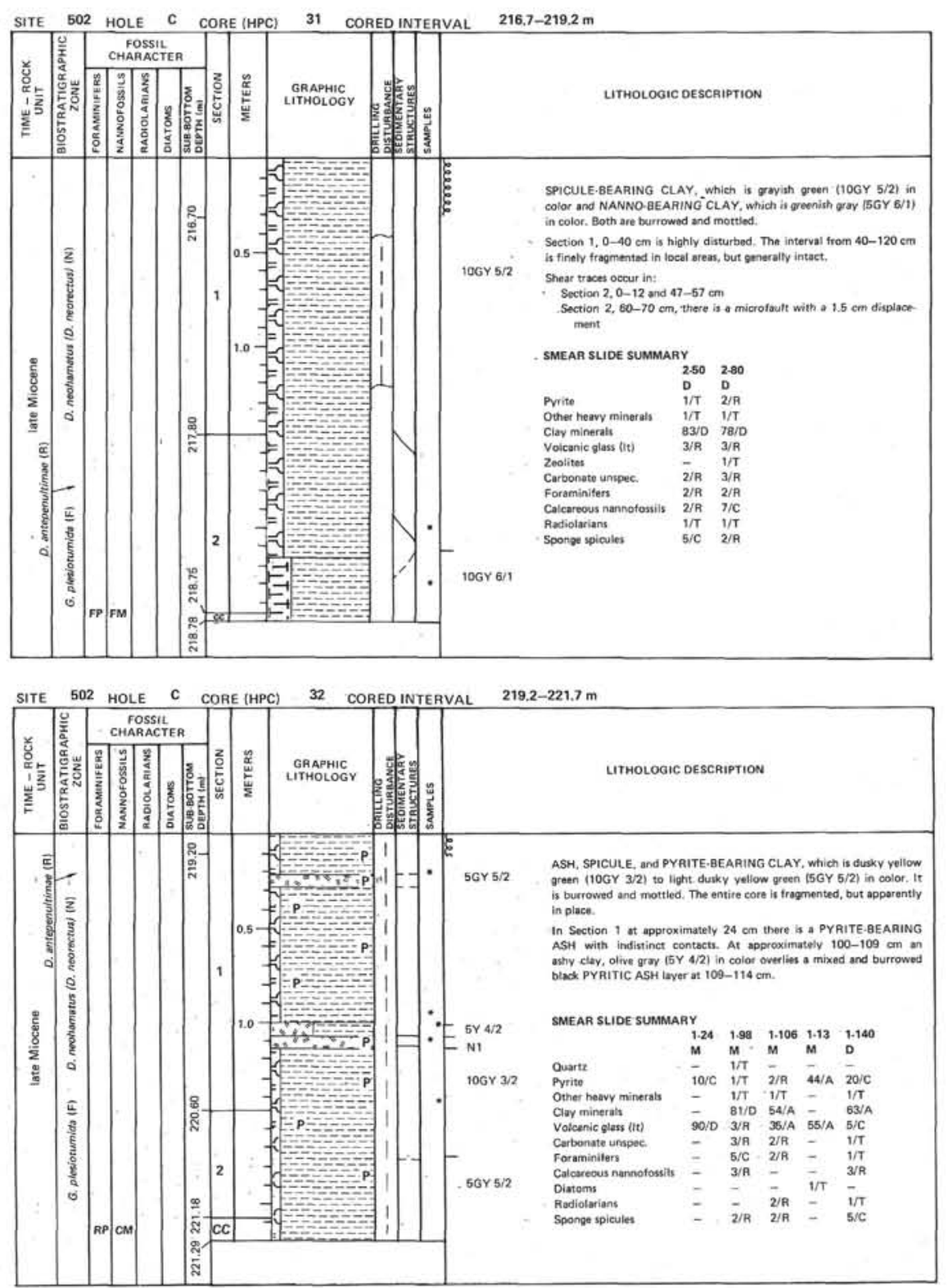

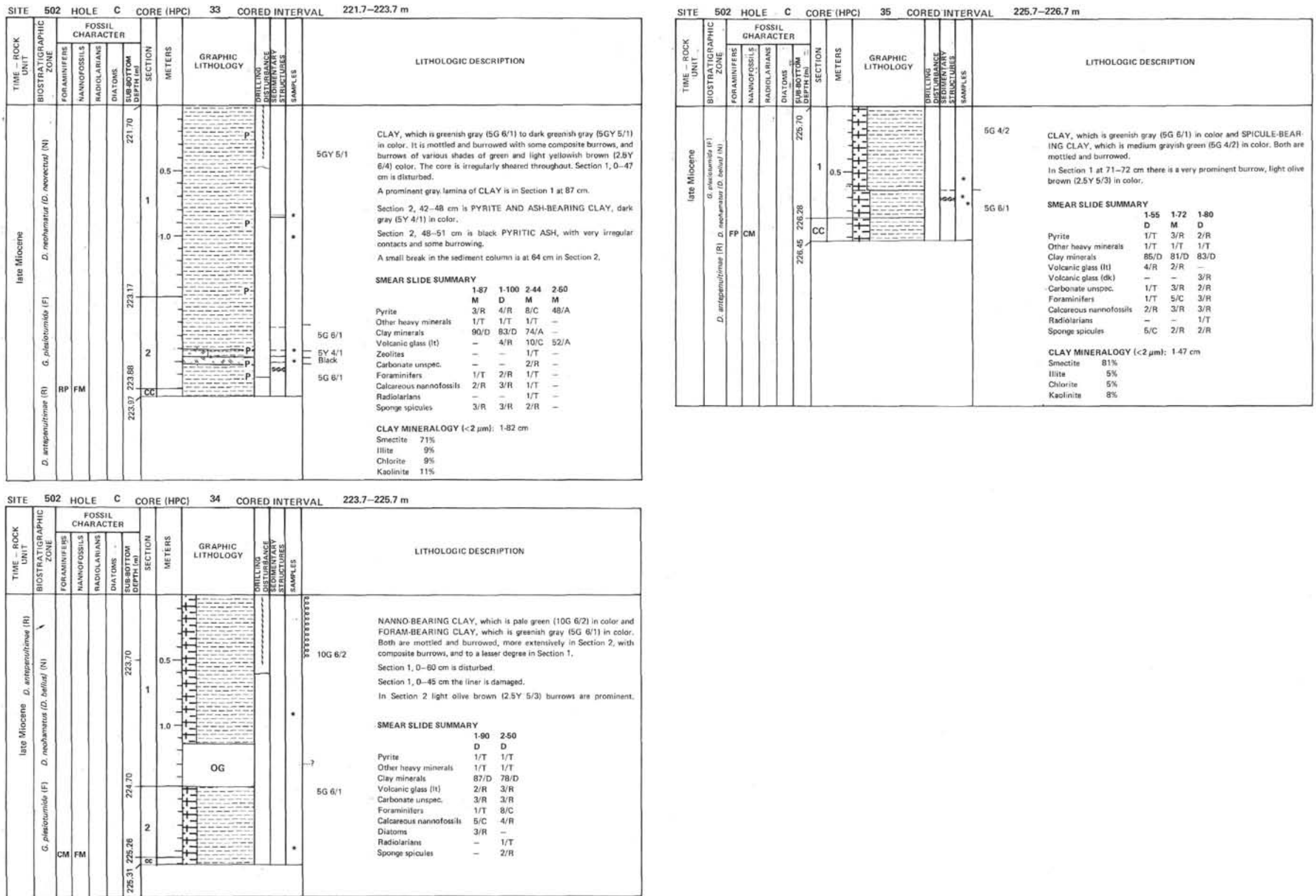

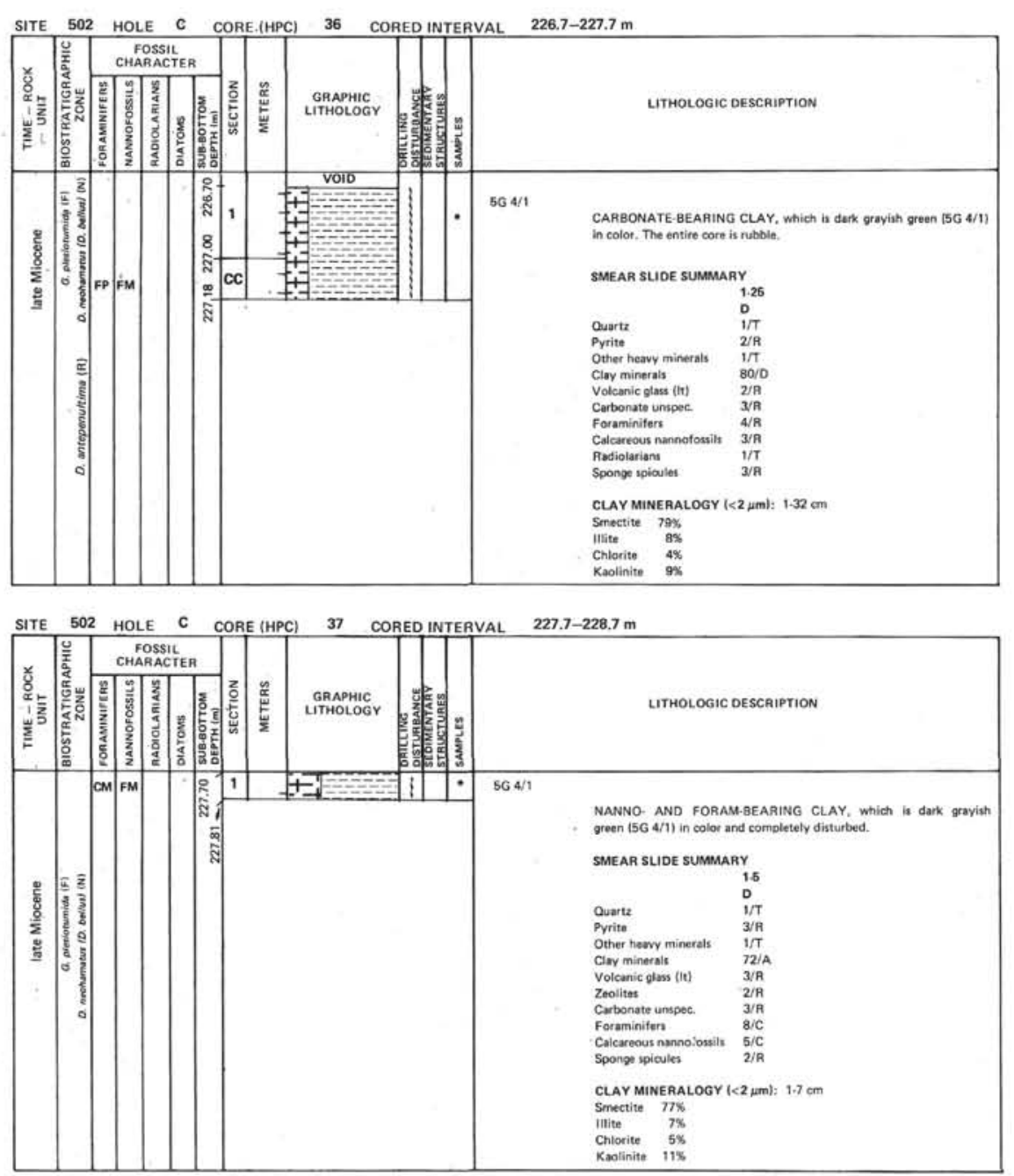


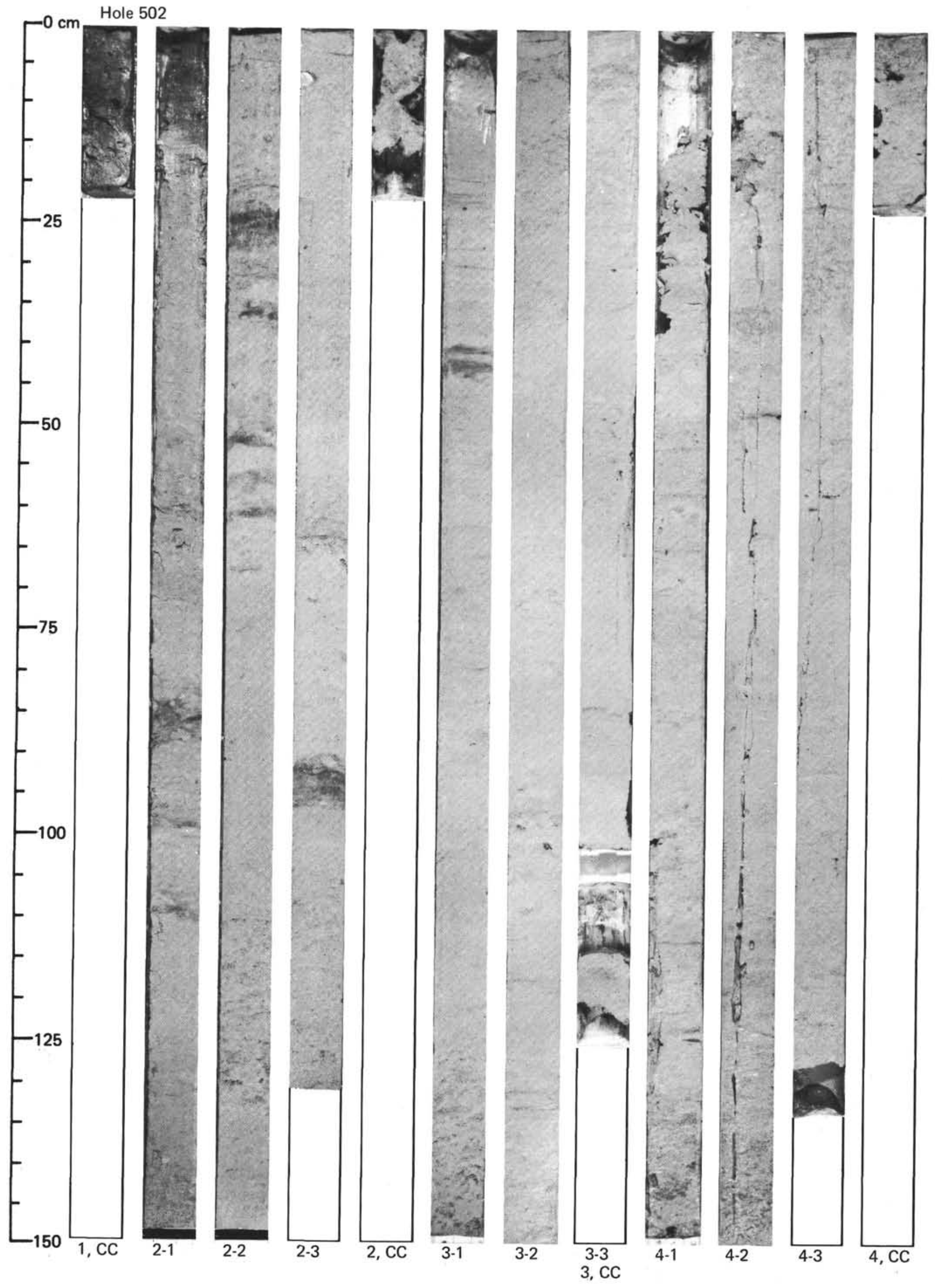




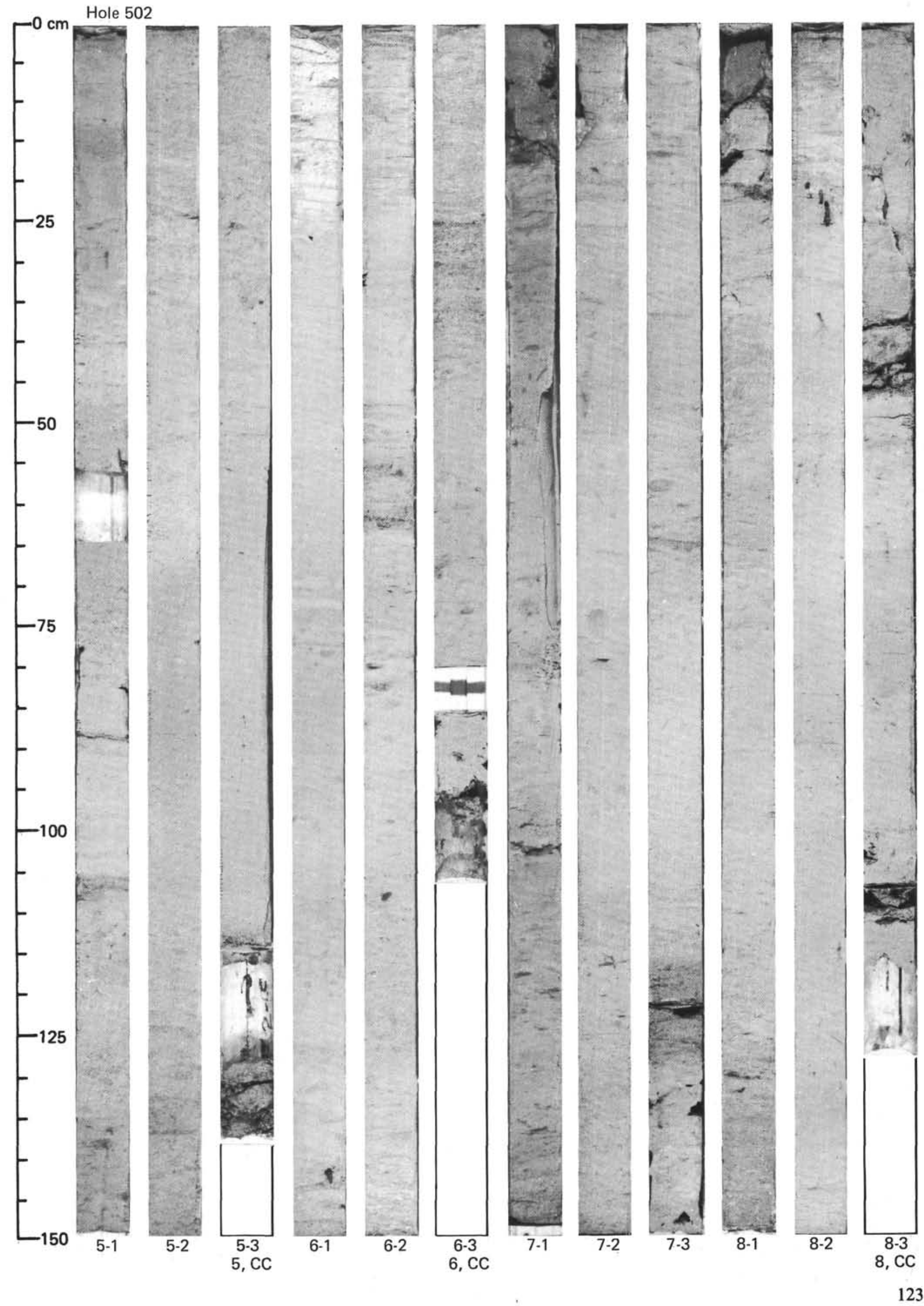




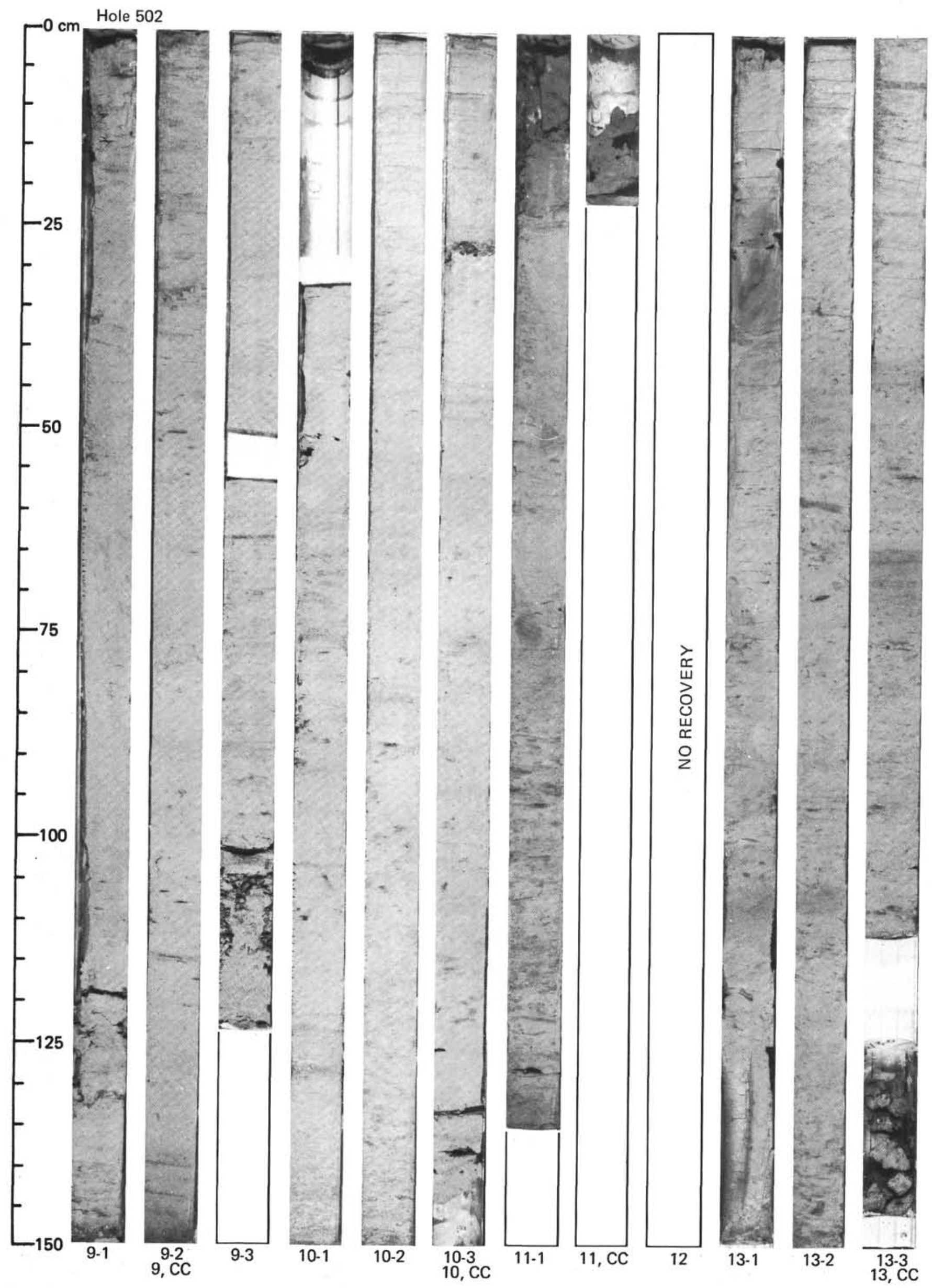




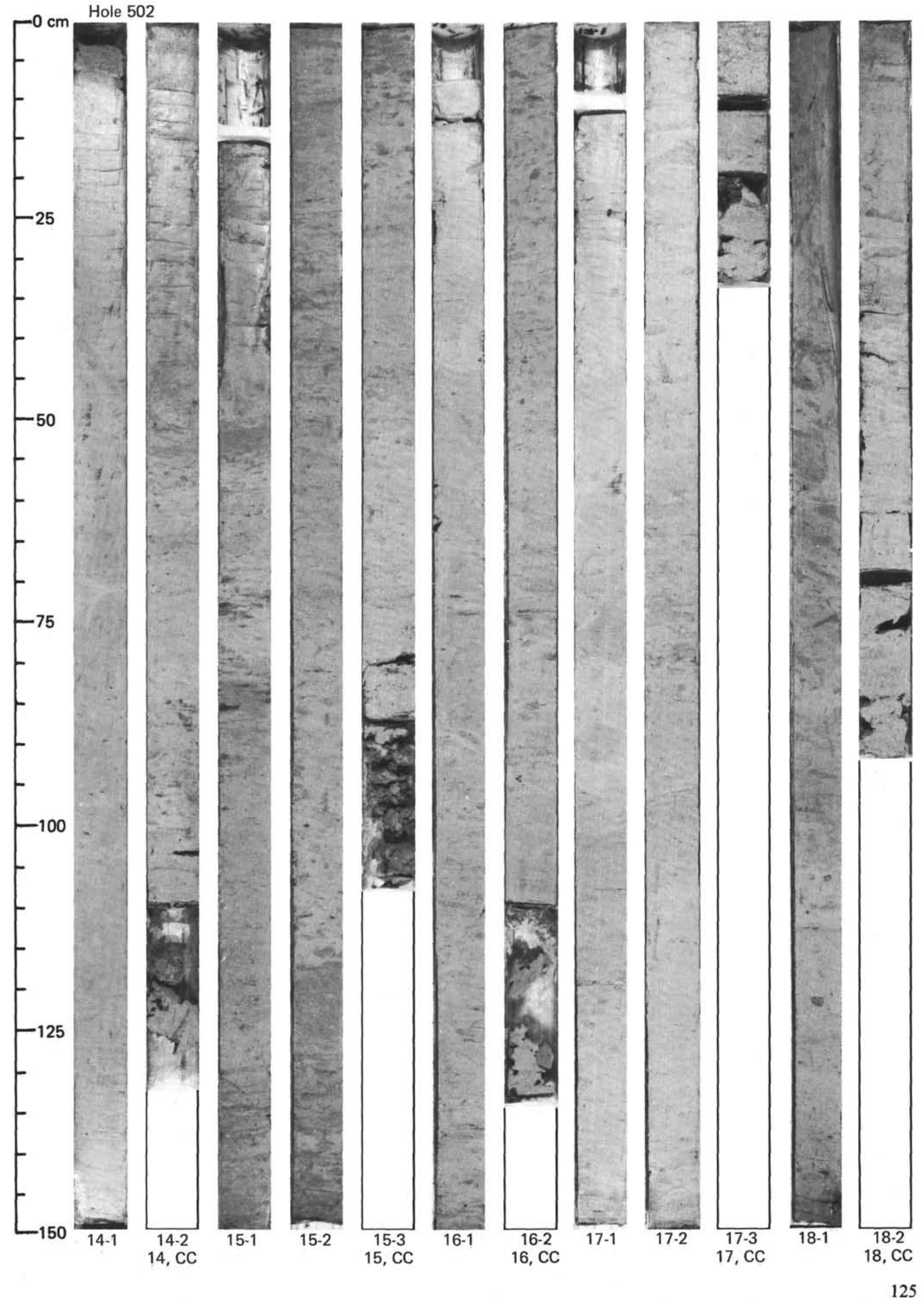


SITE 502

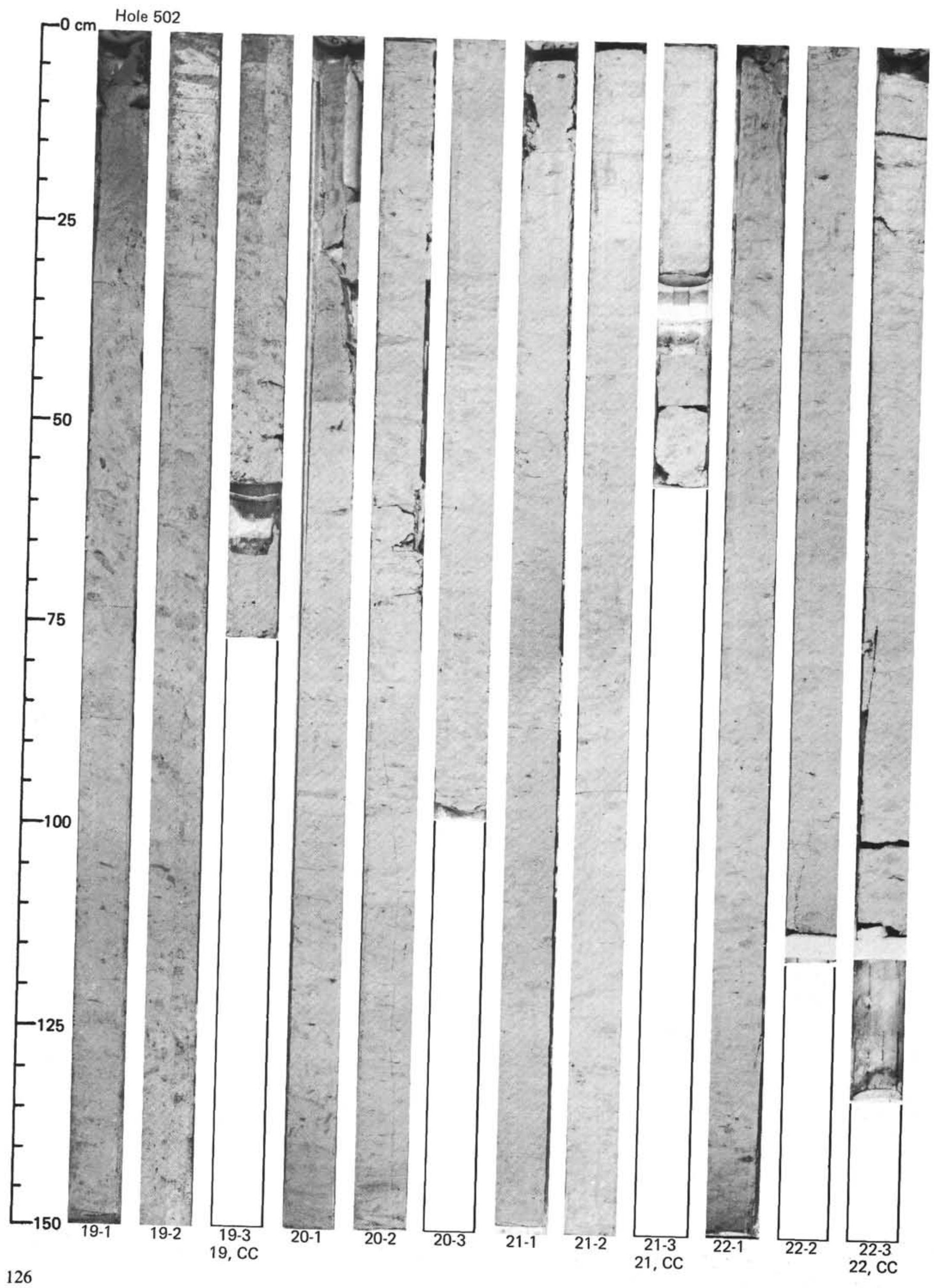




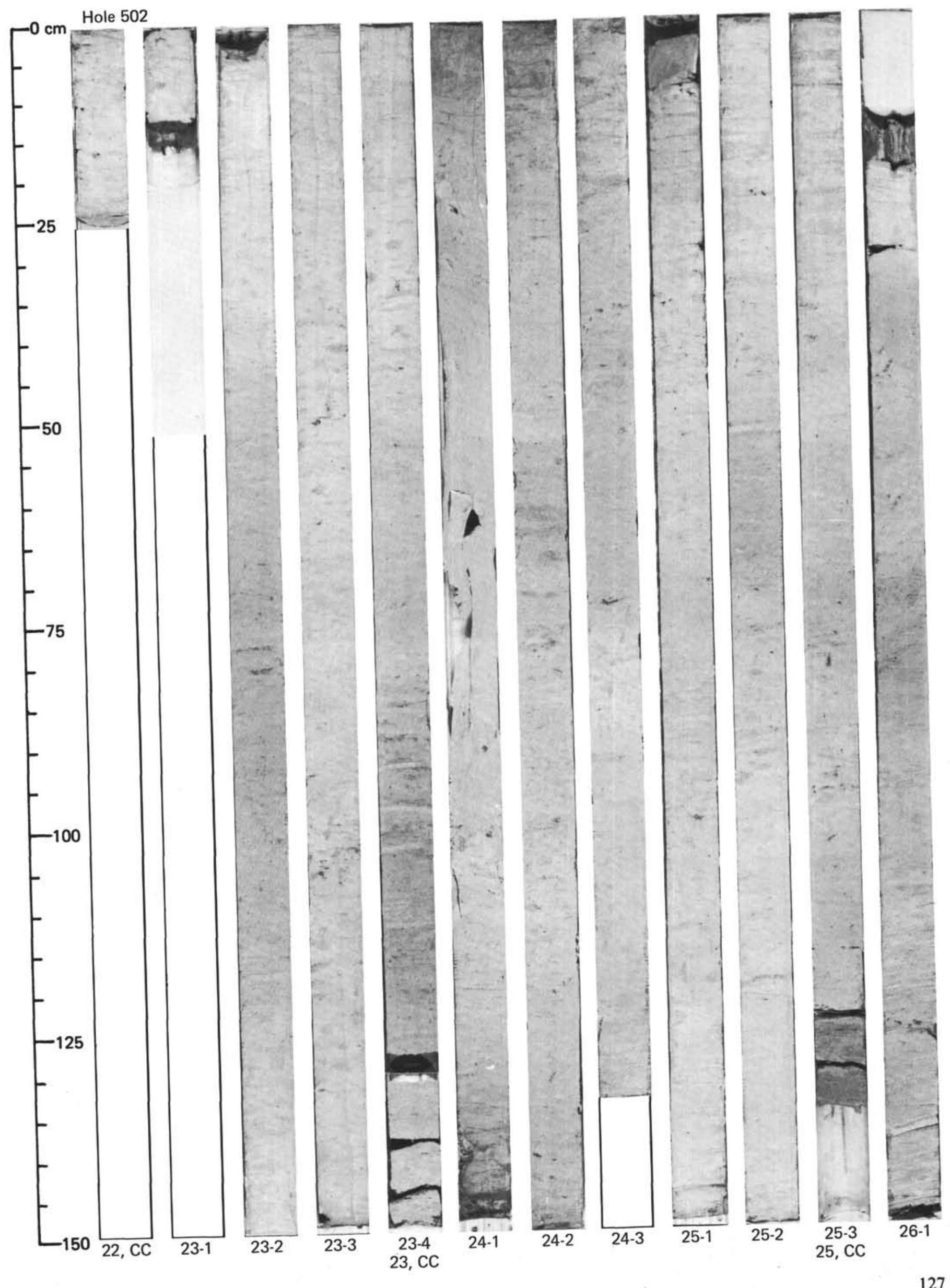




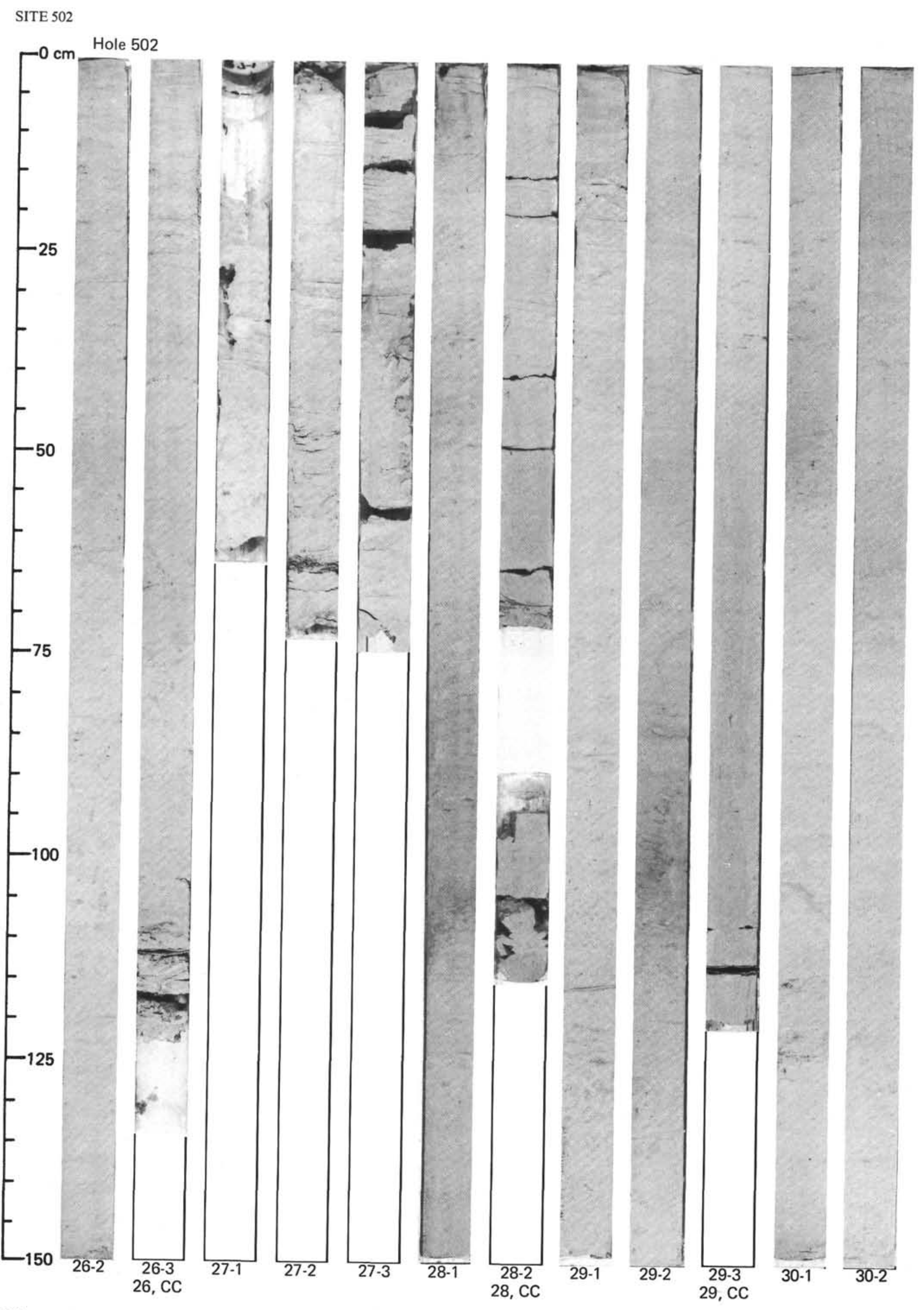




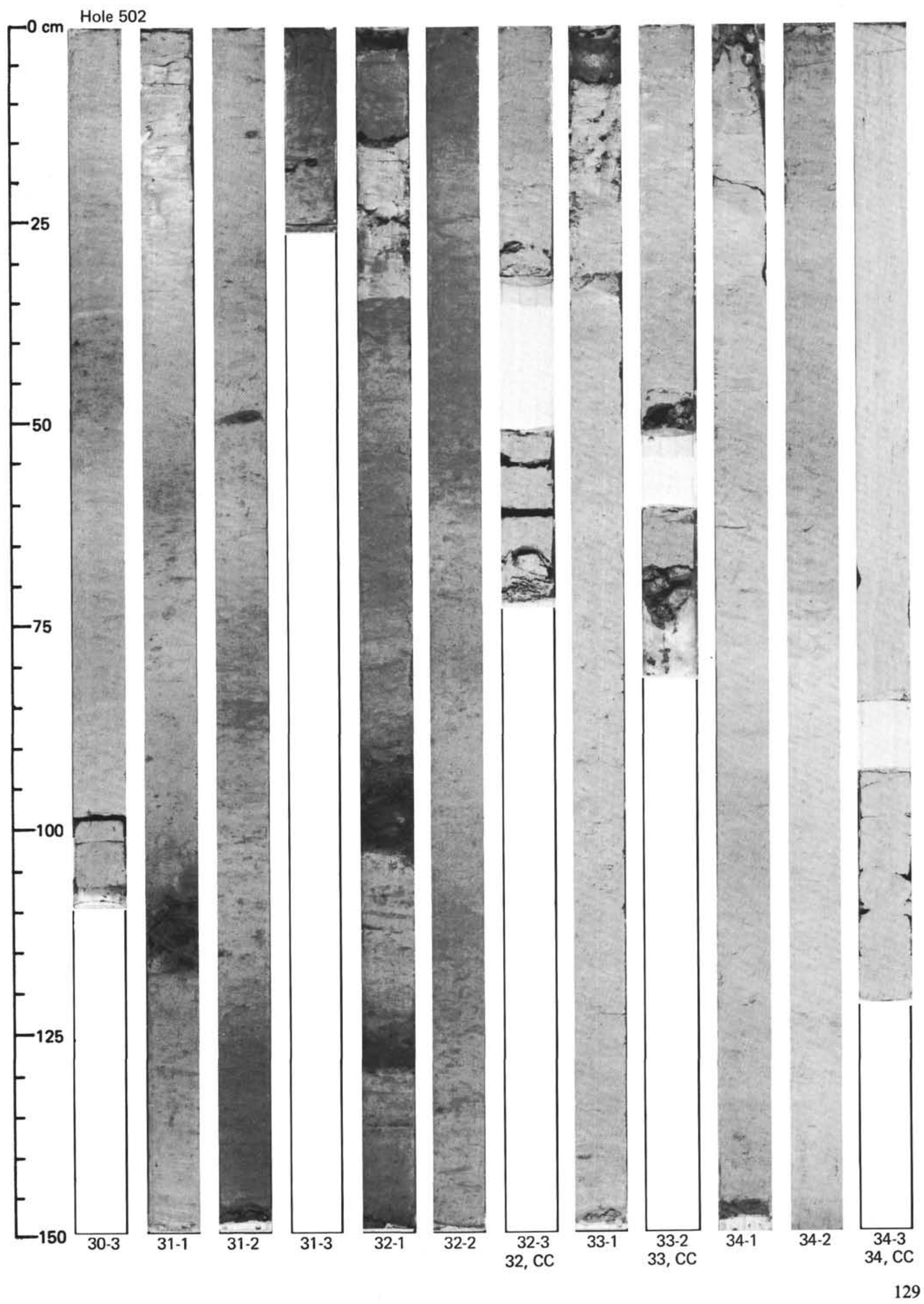




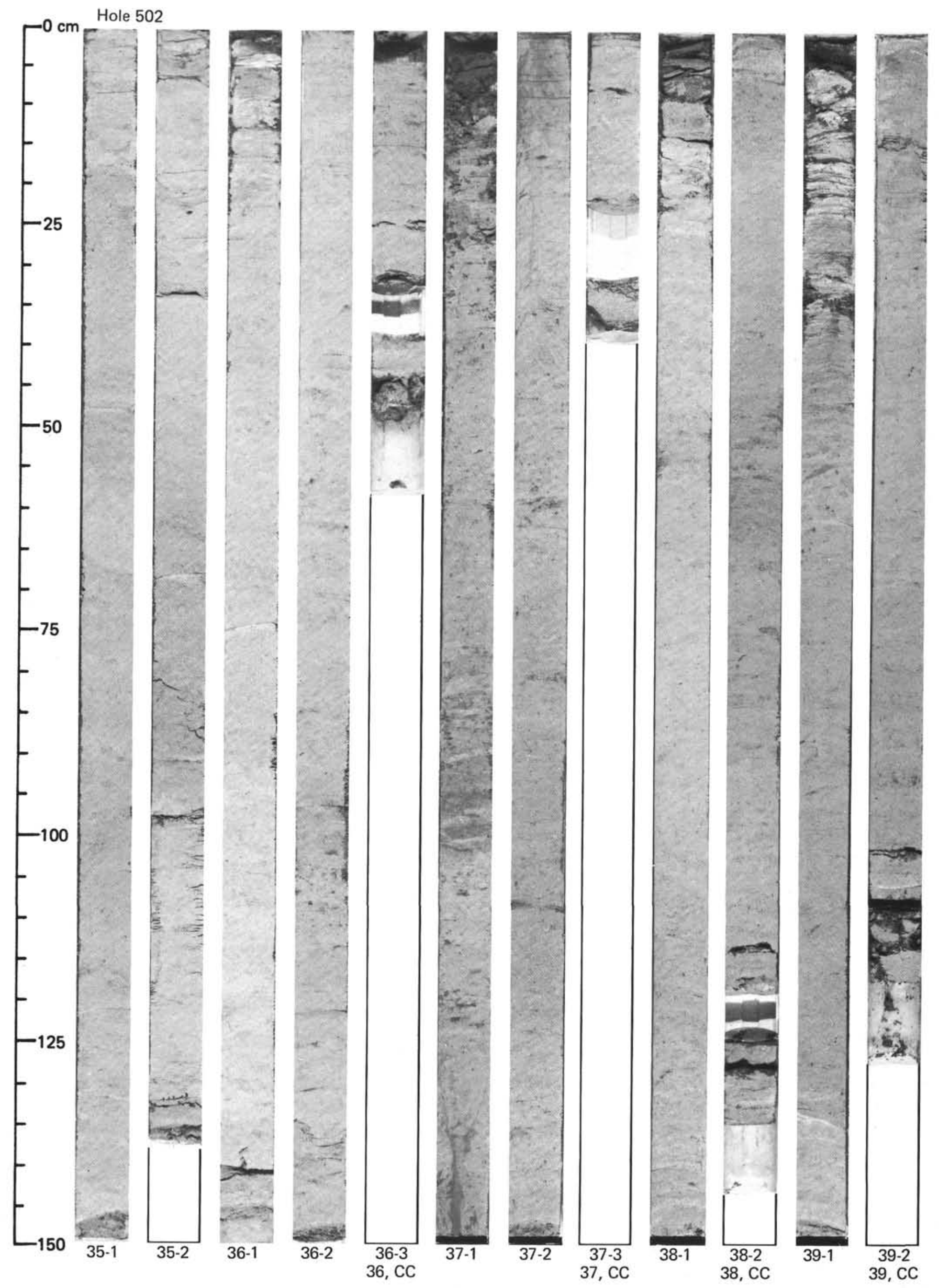




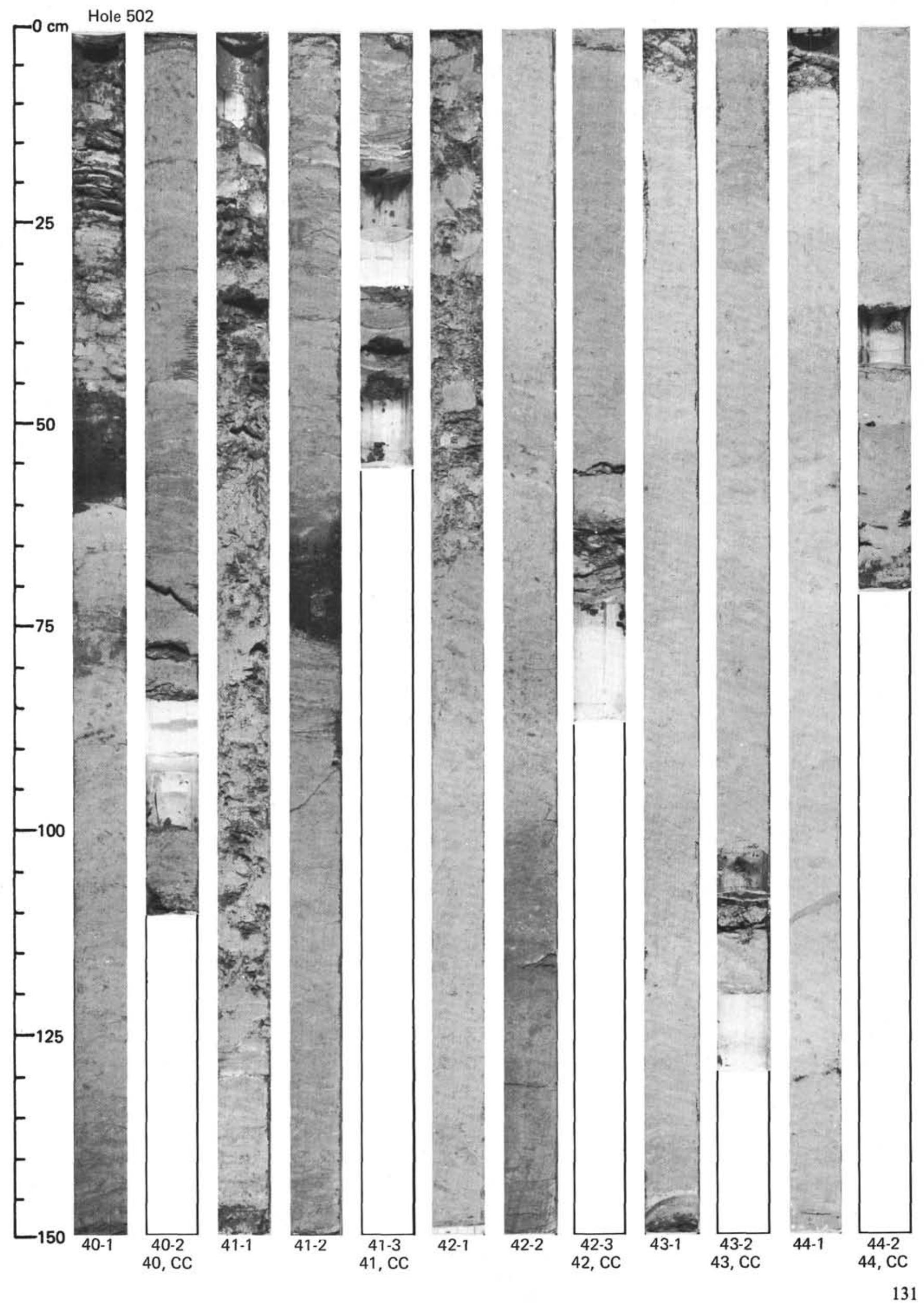




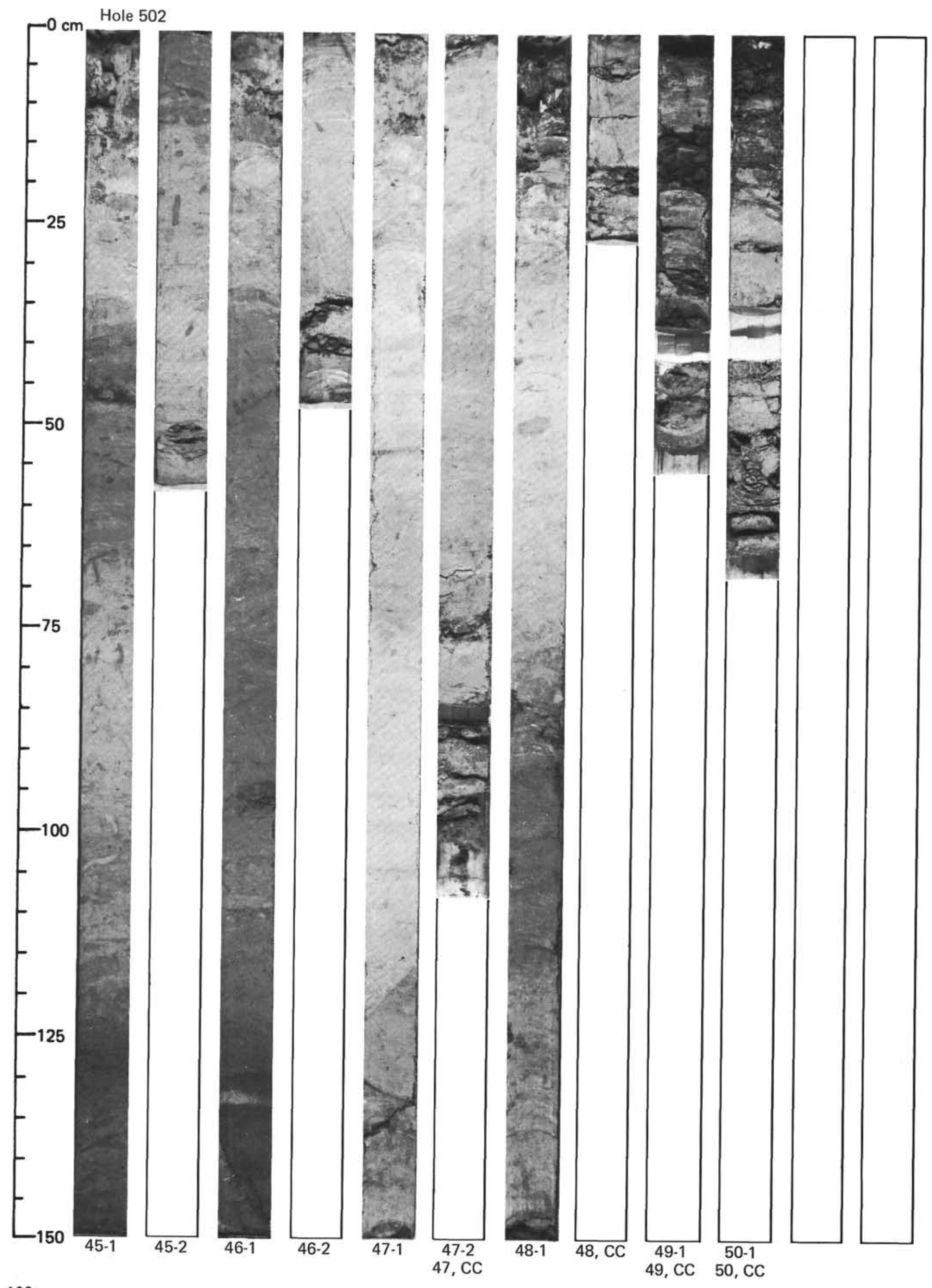




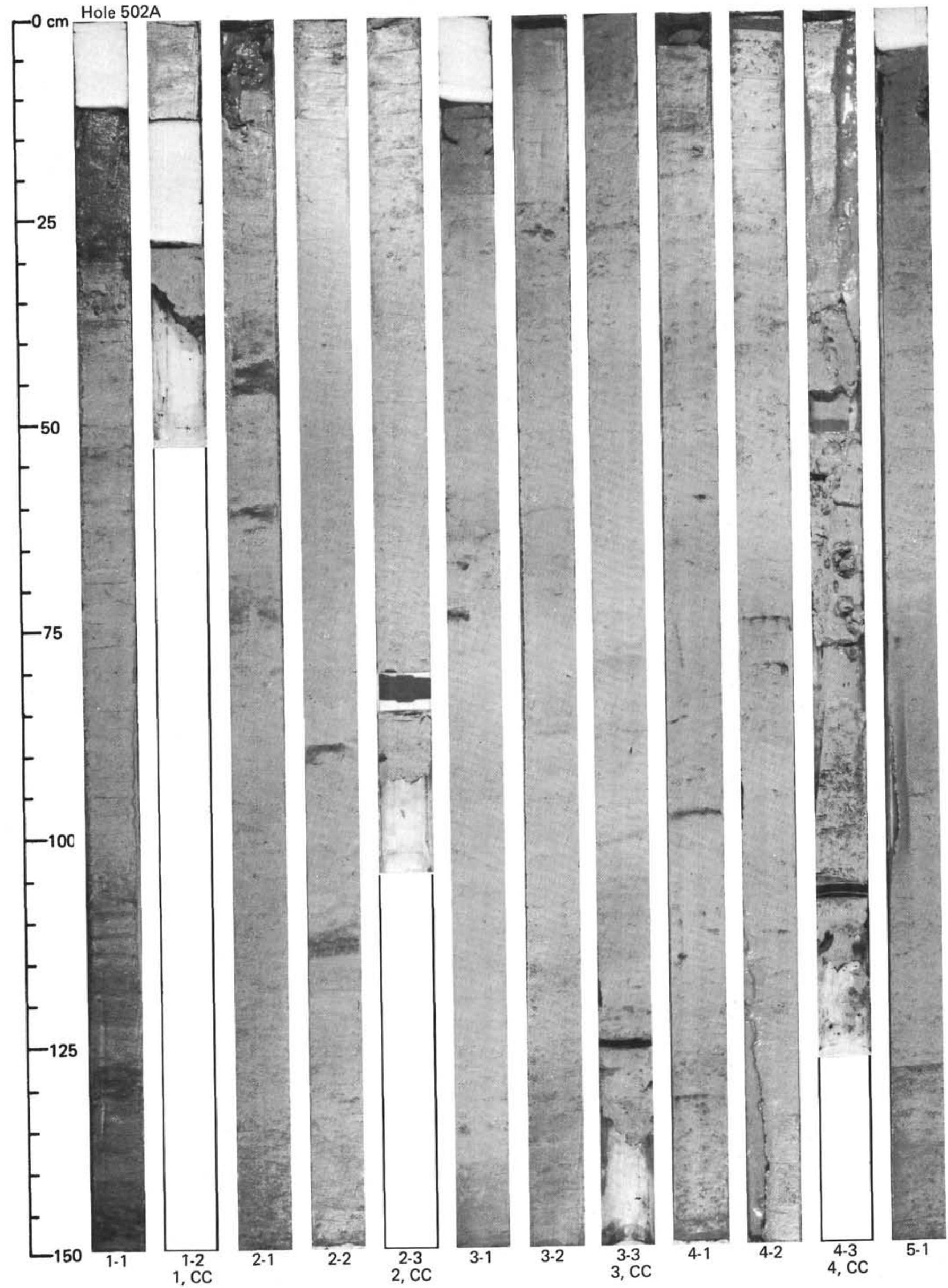




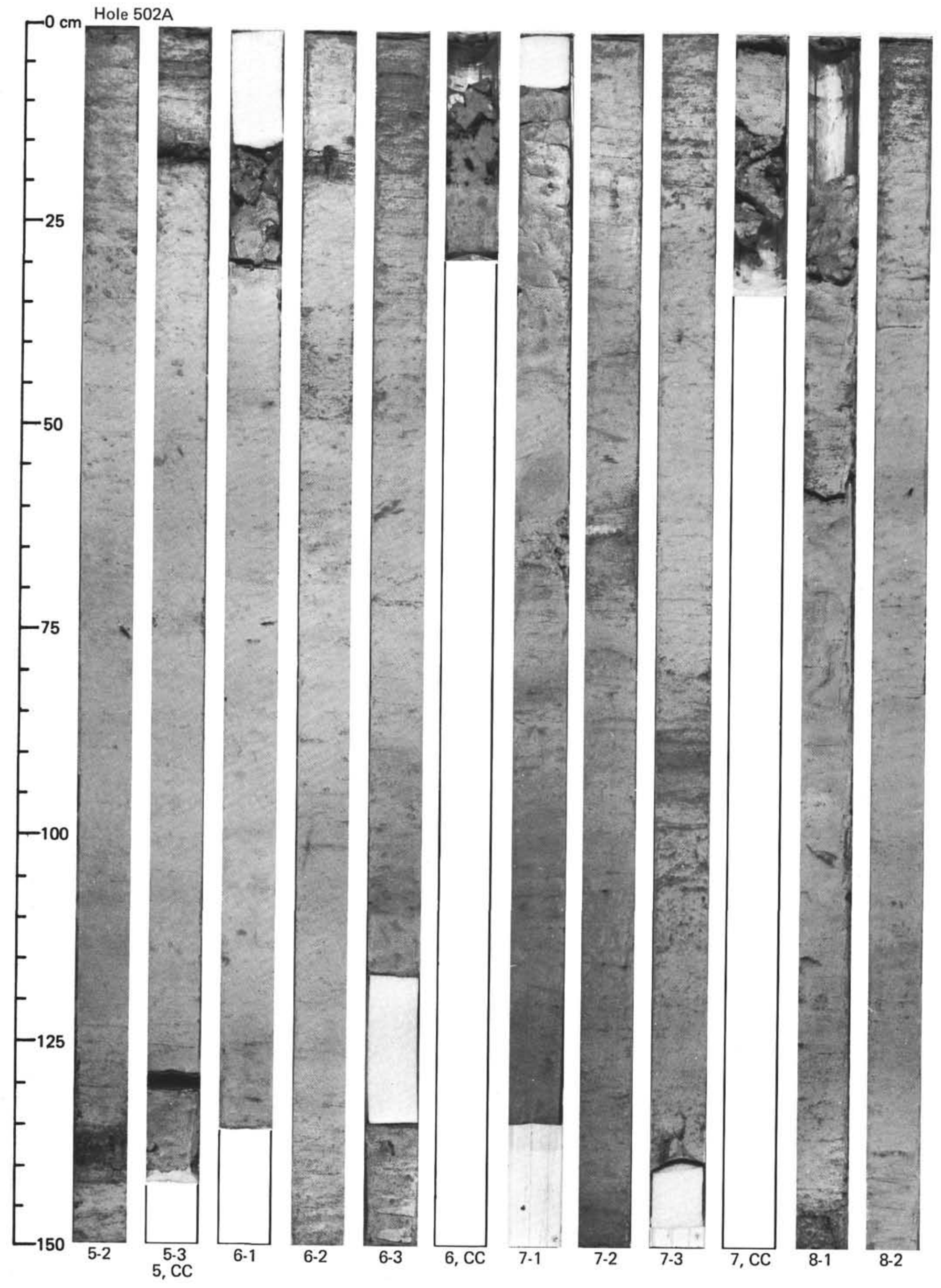



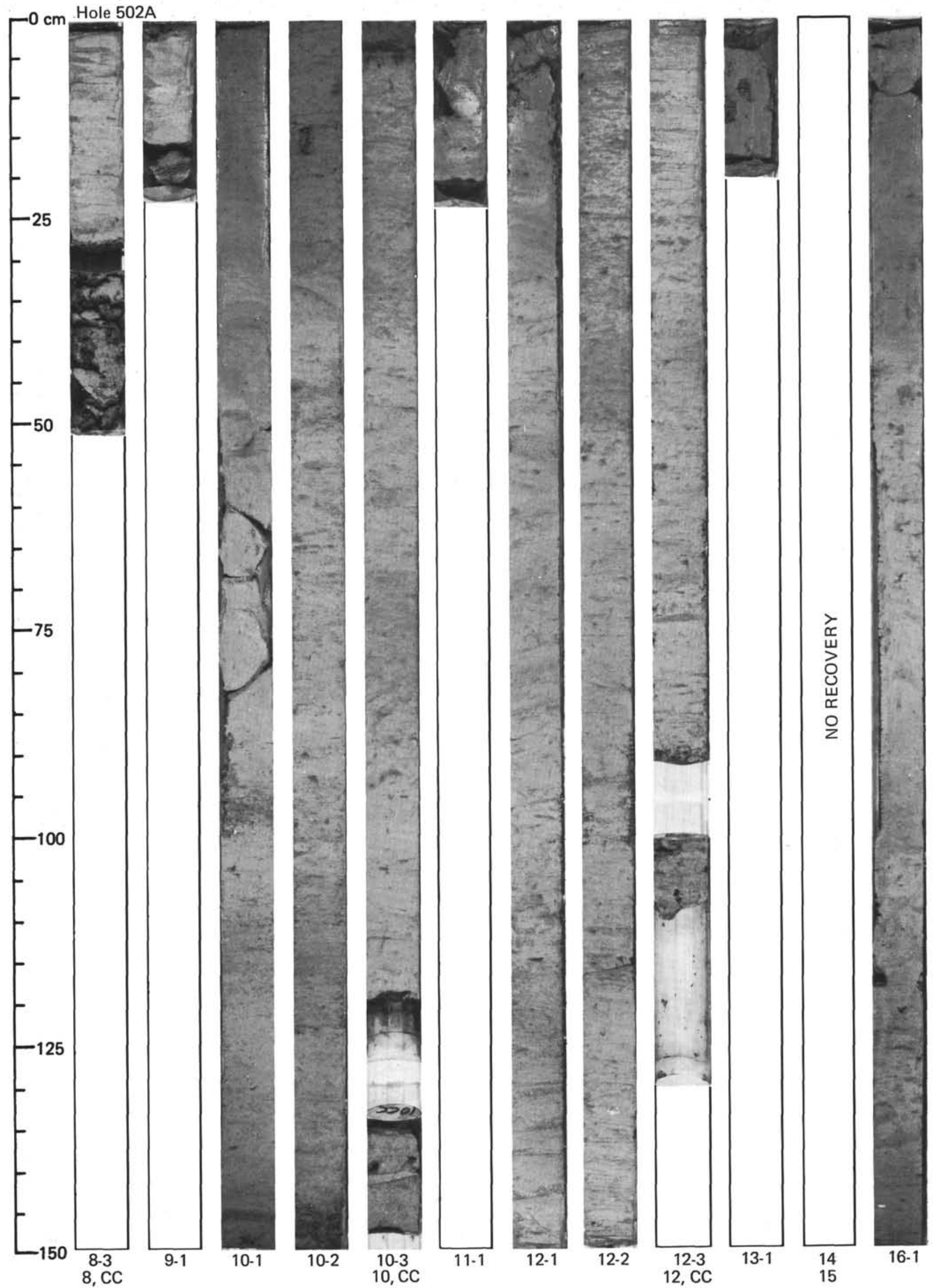
SITE 502

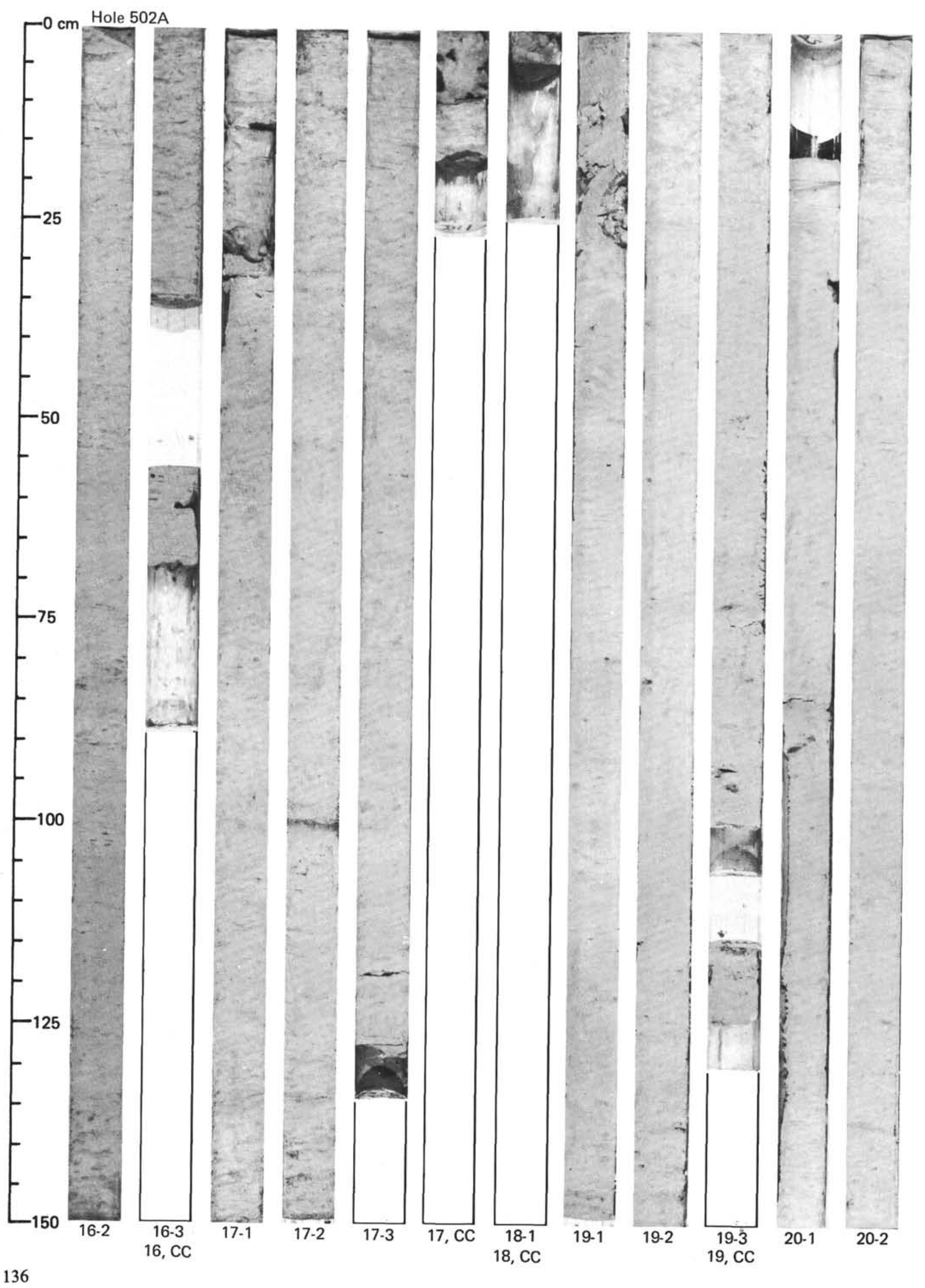




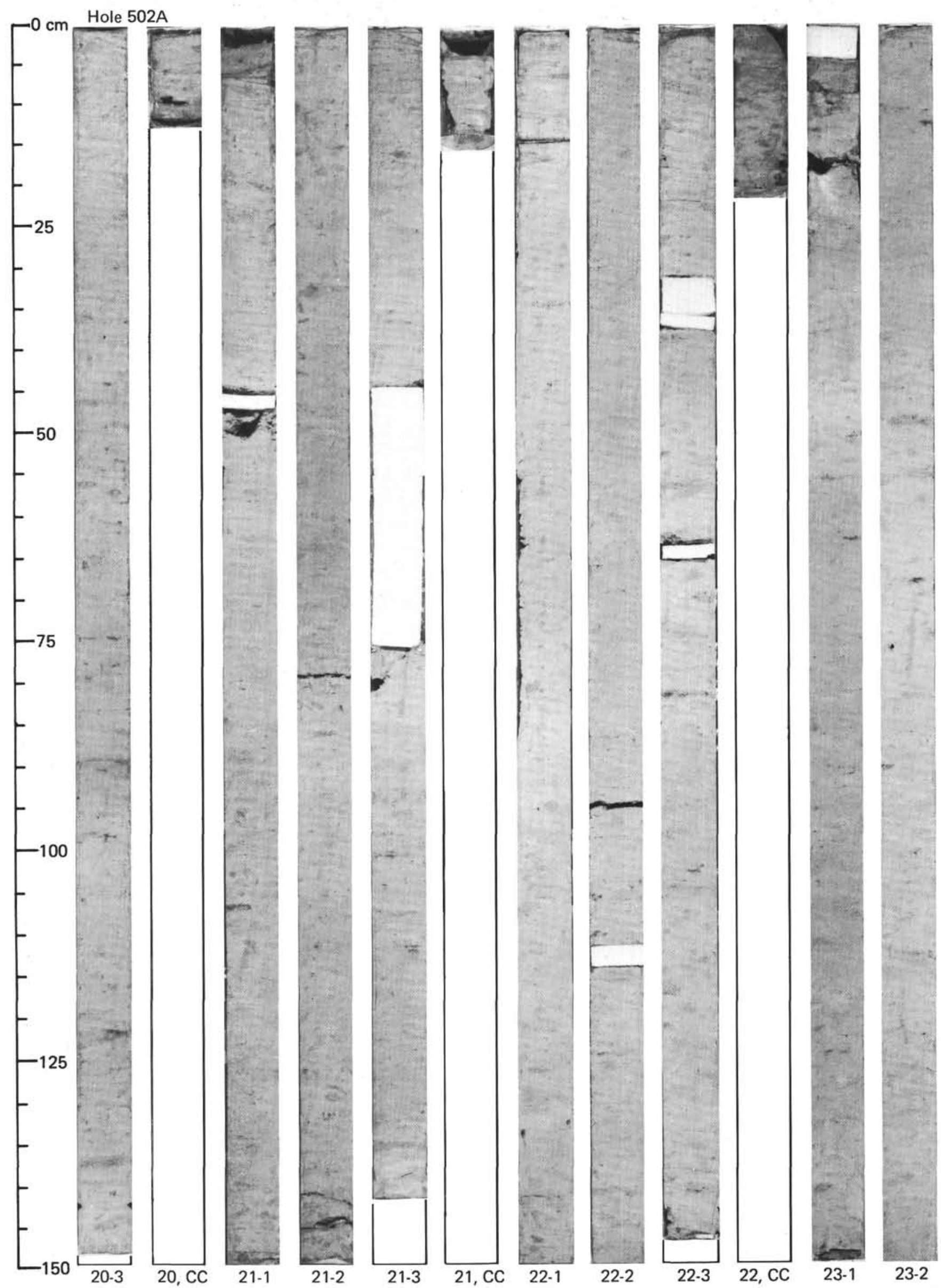




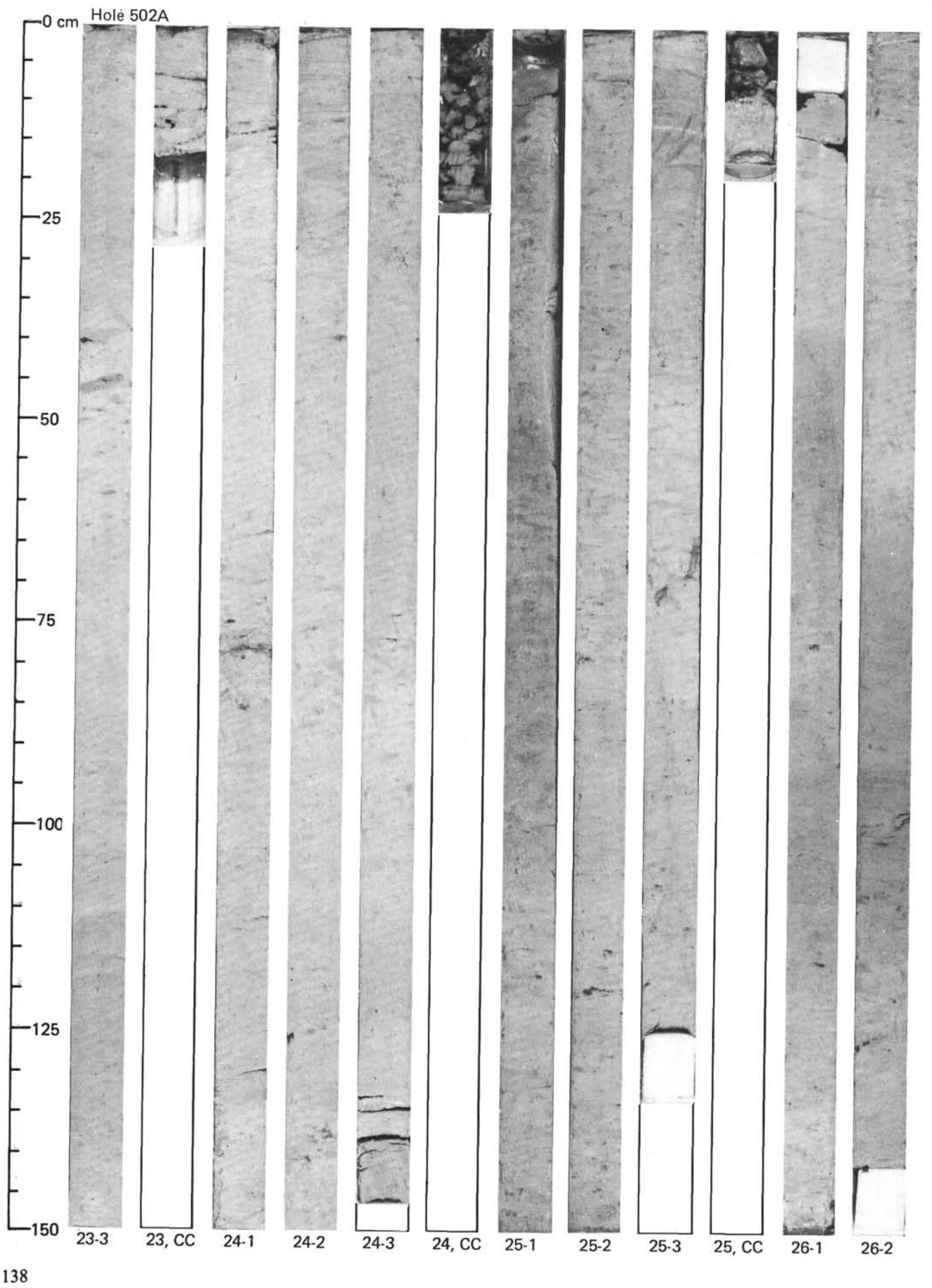




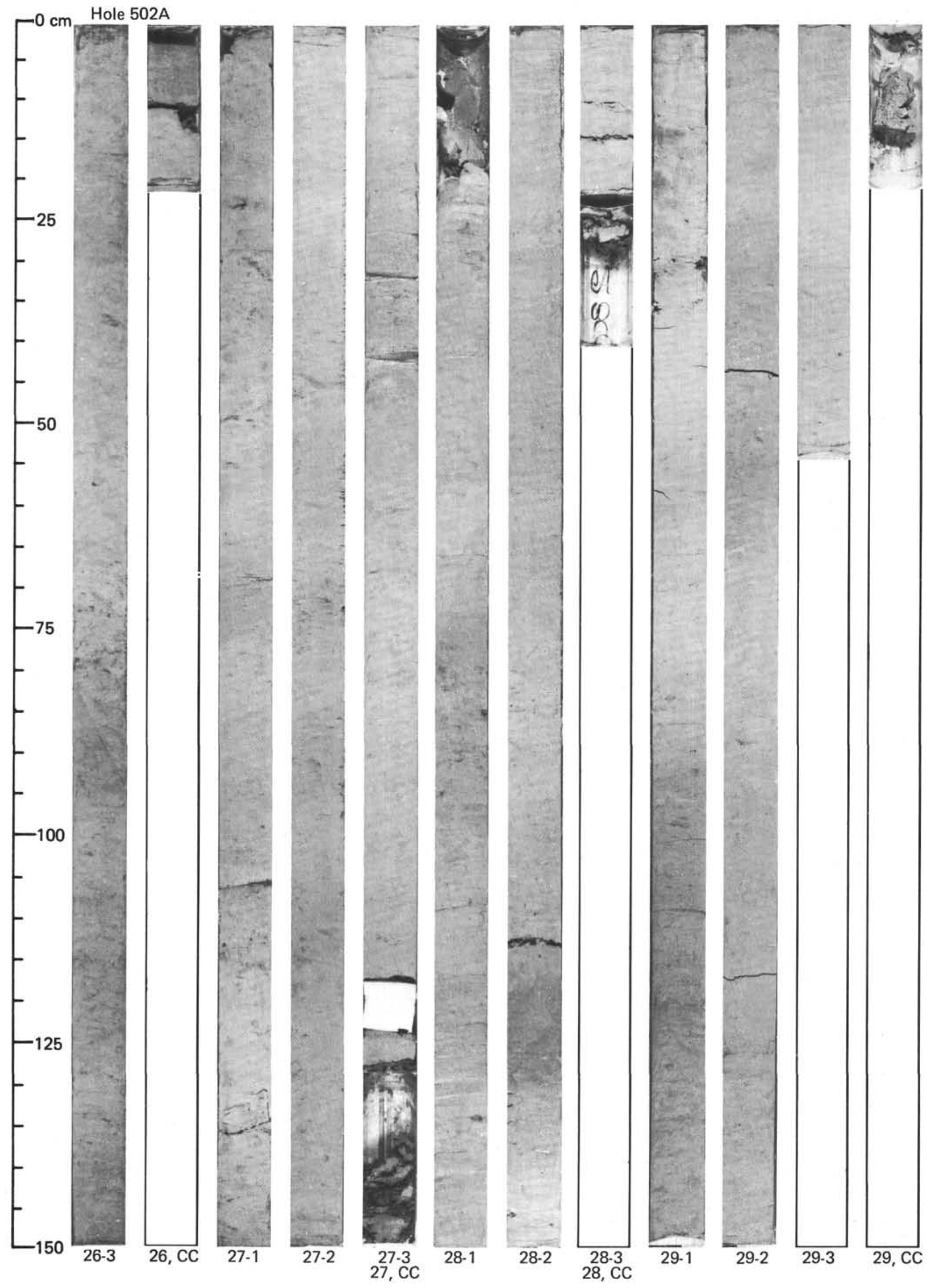




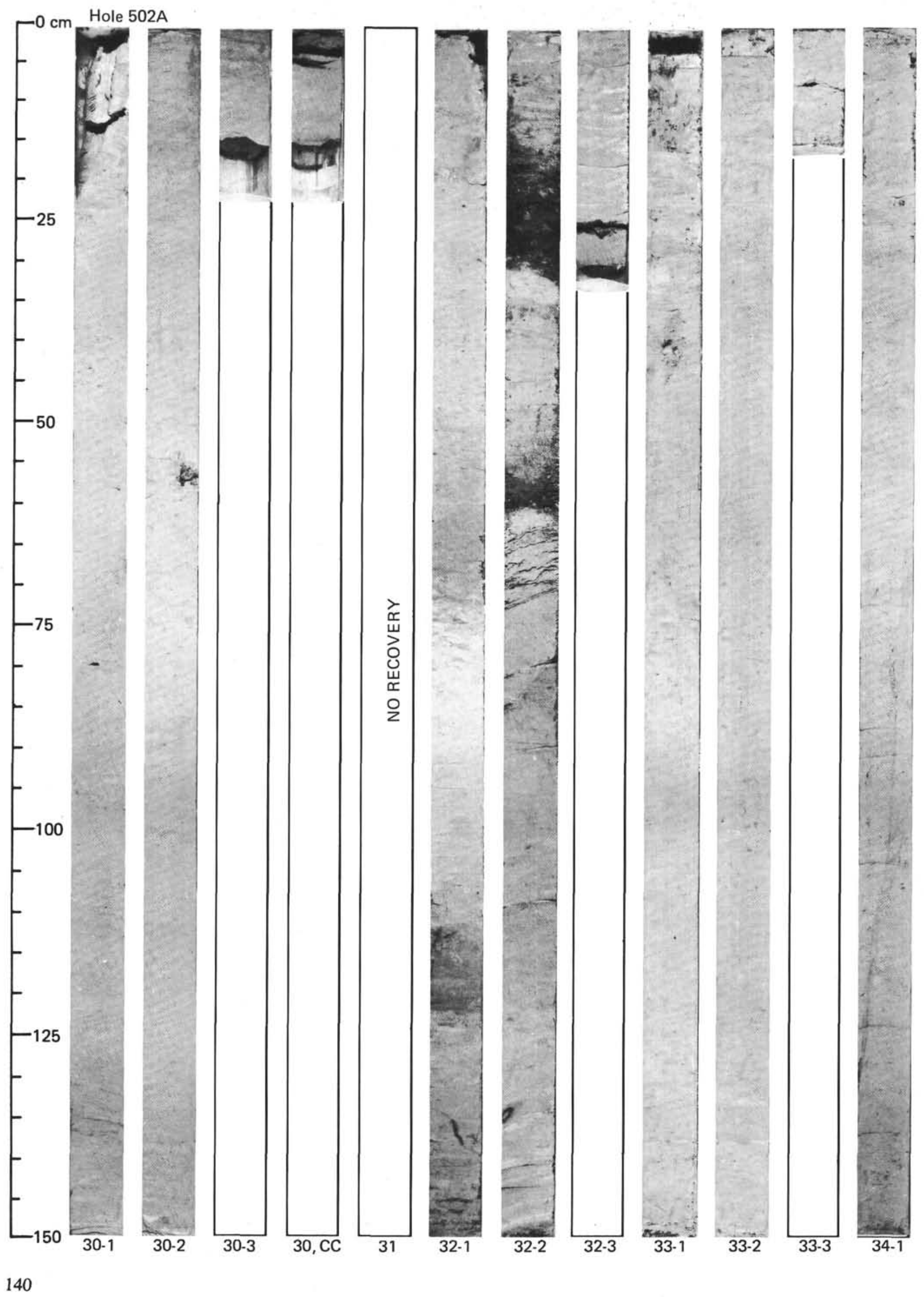




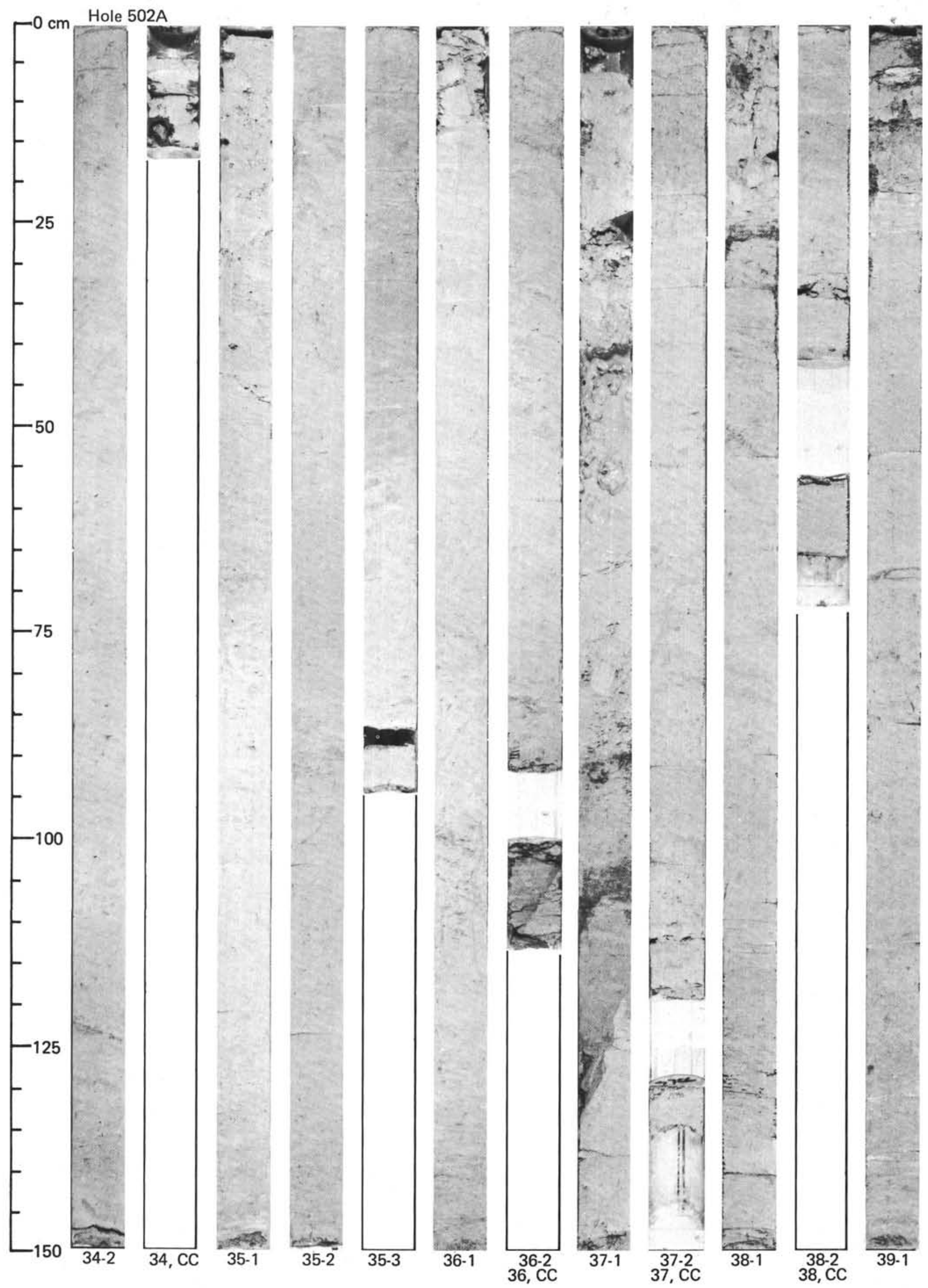




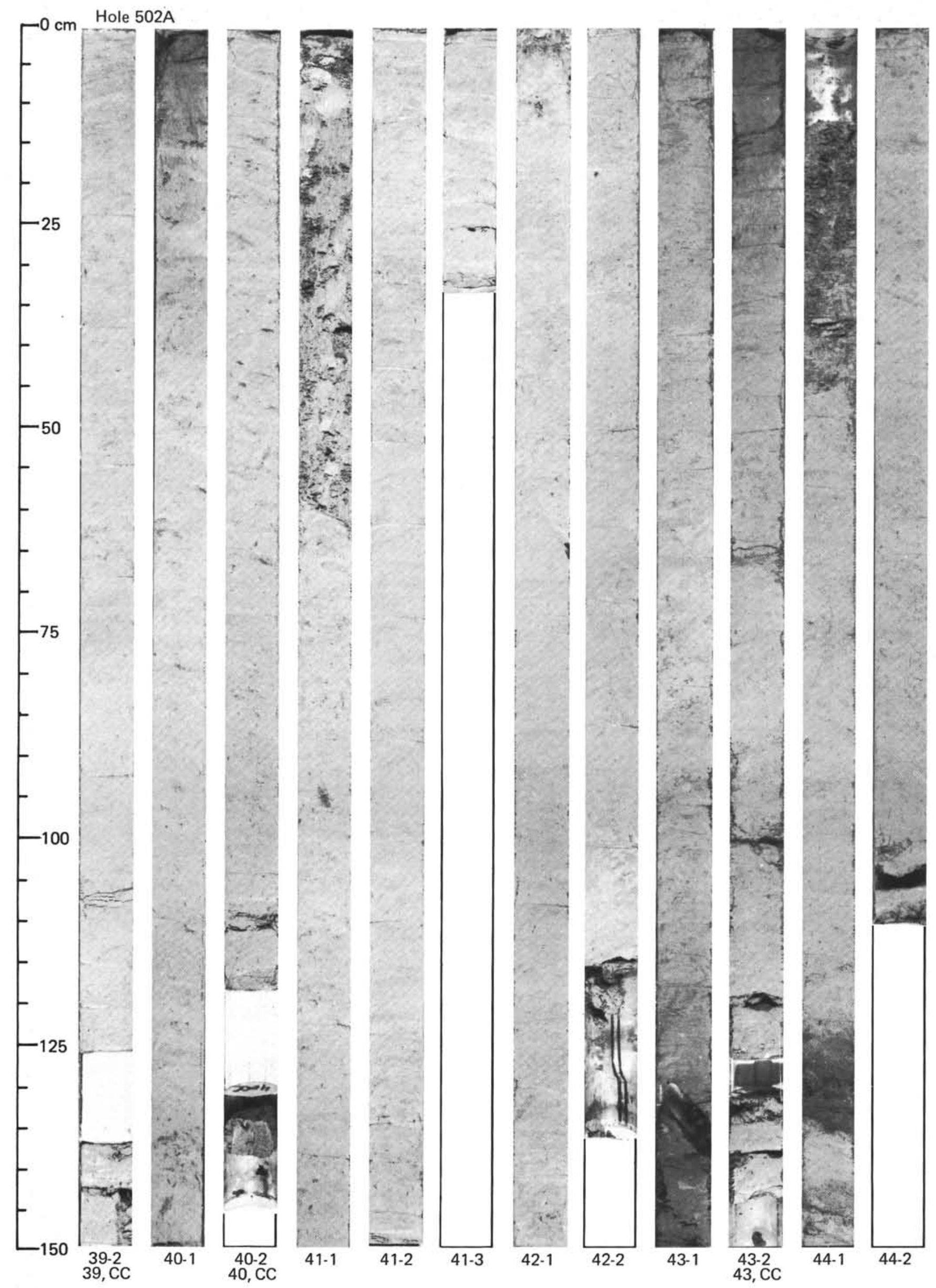




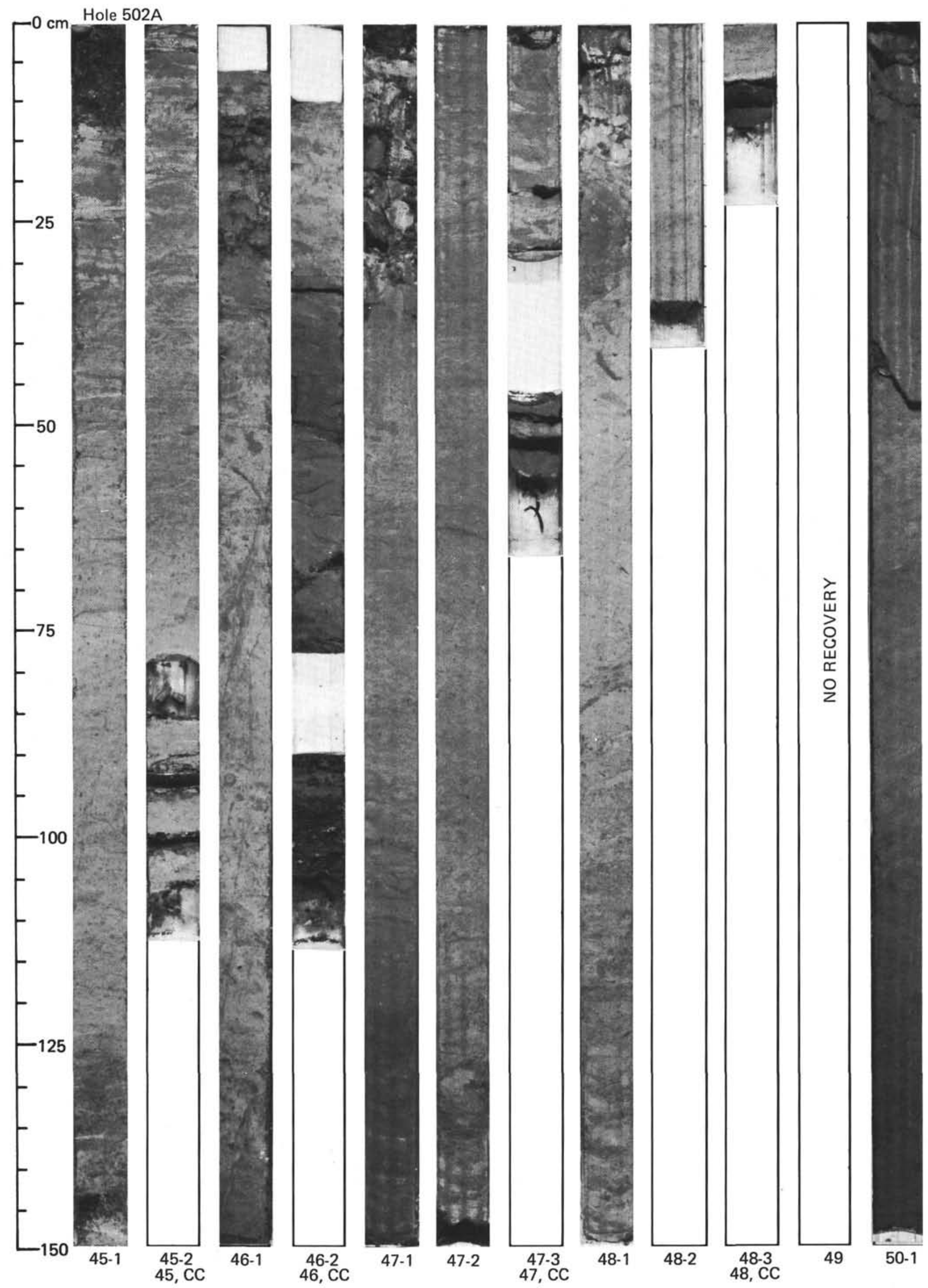




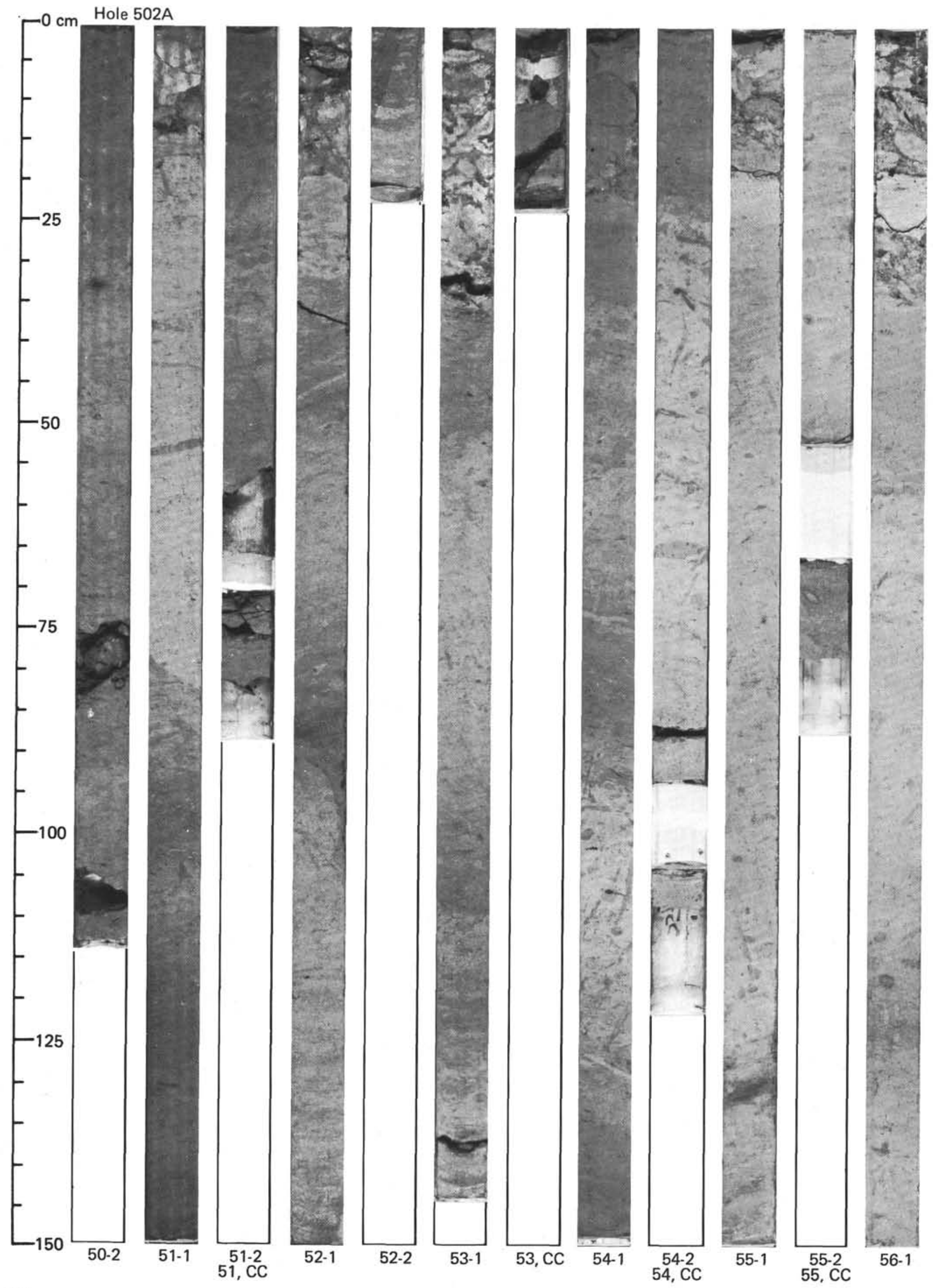



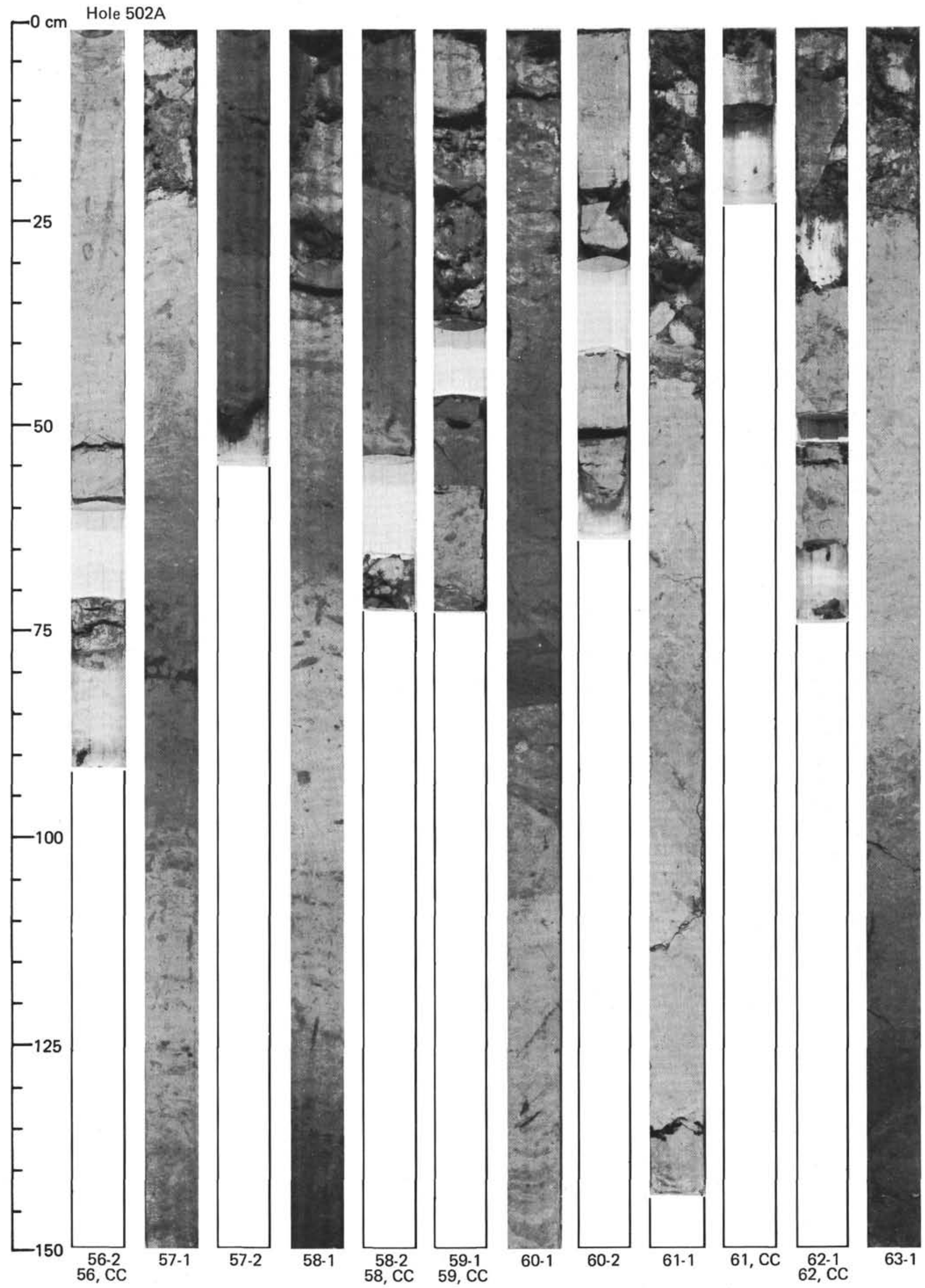


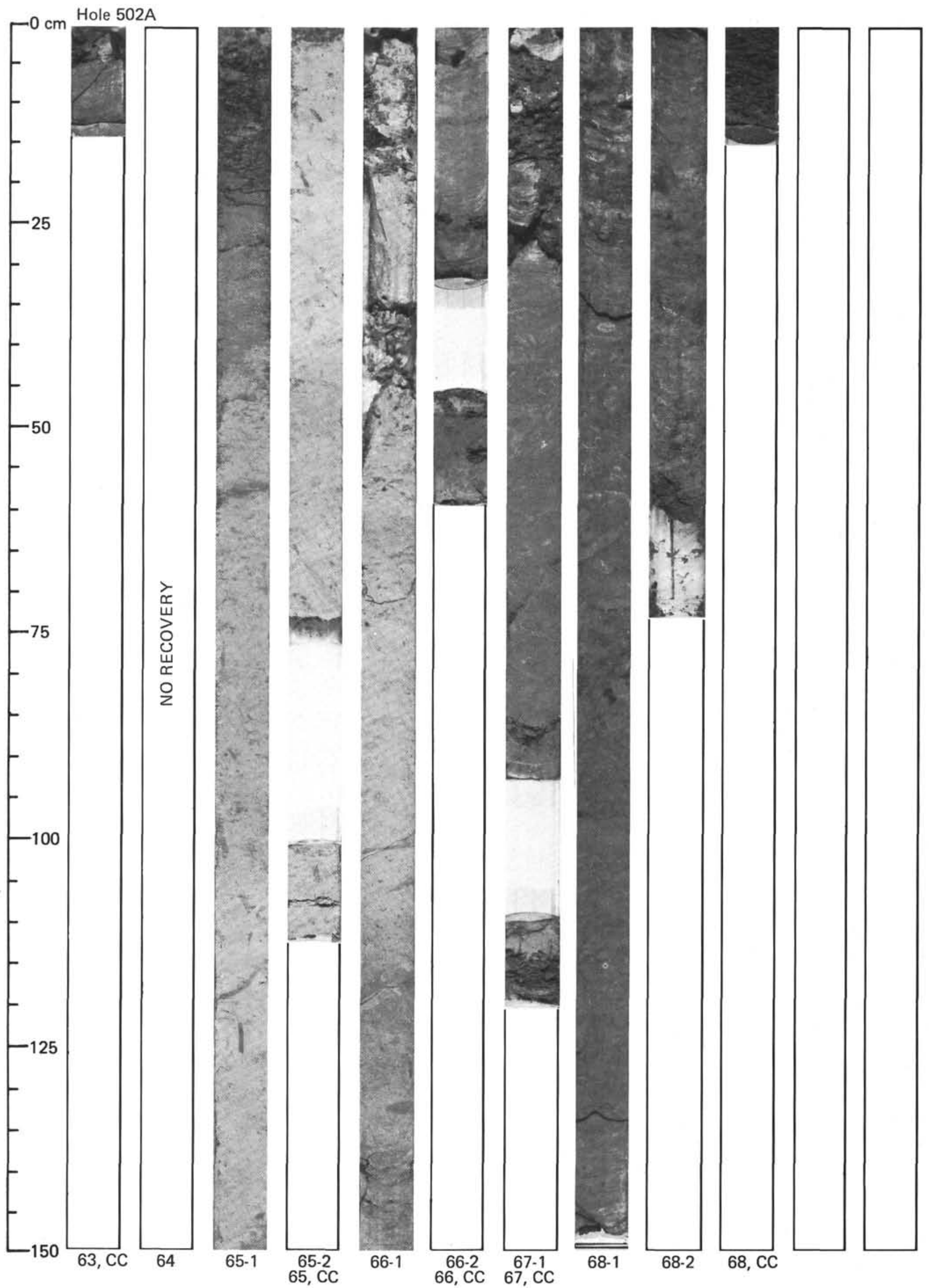



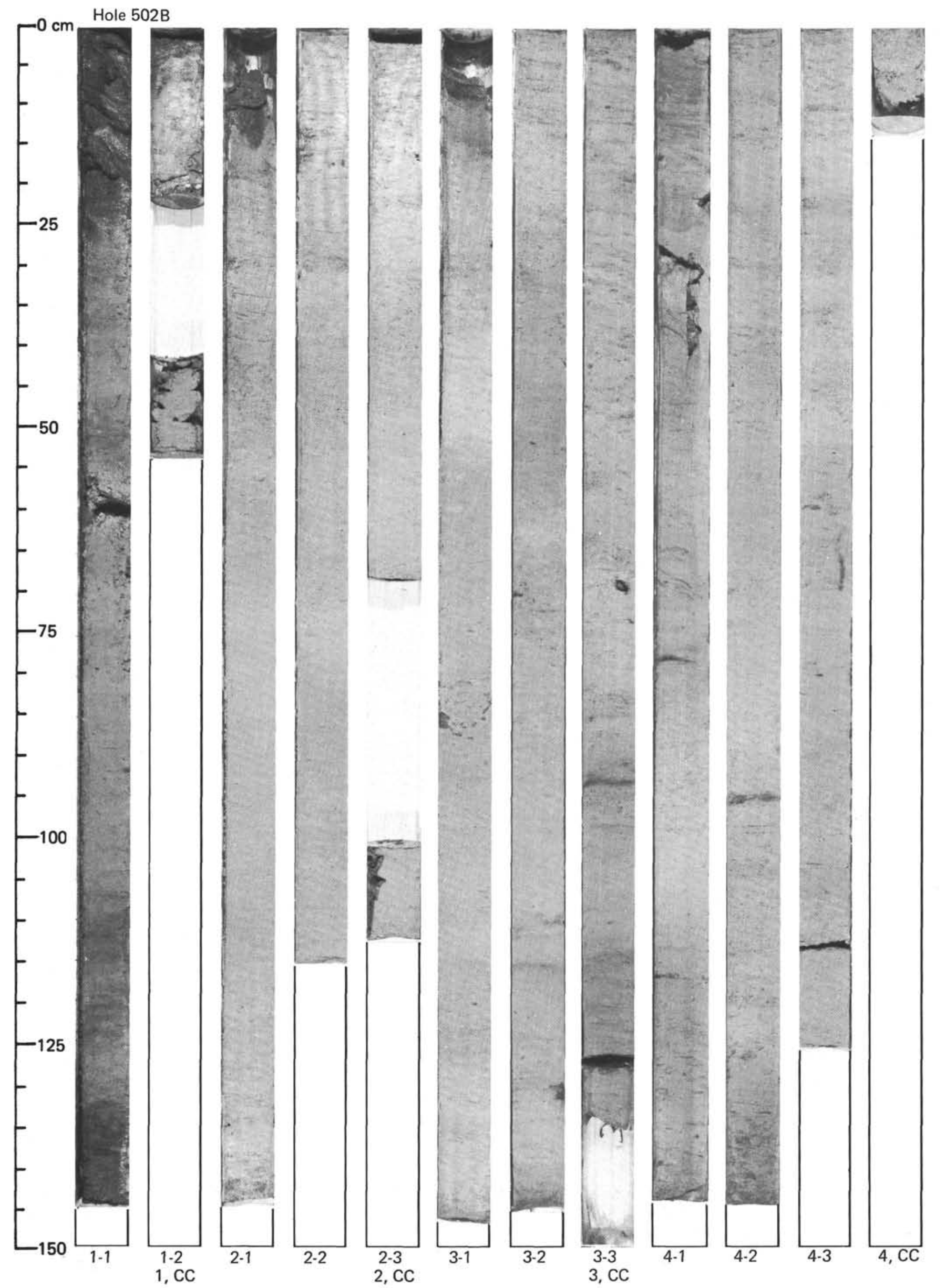


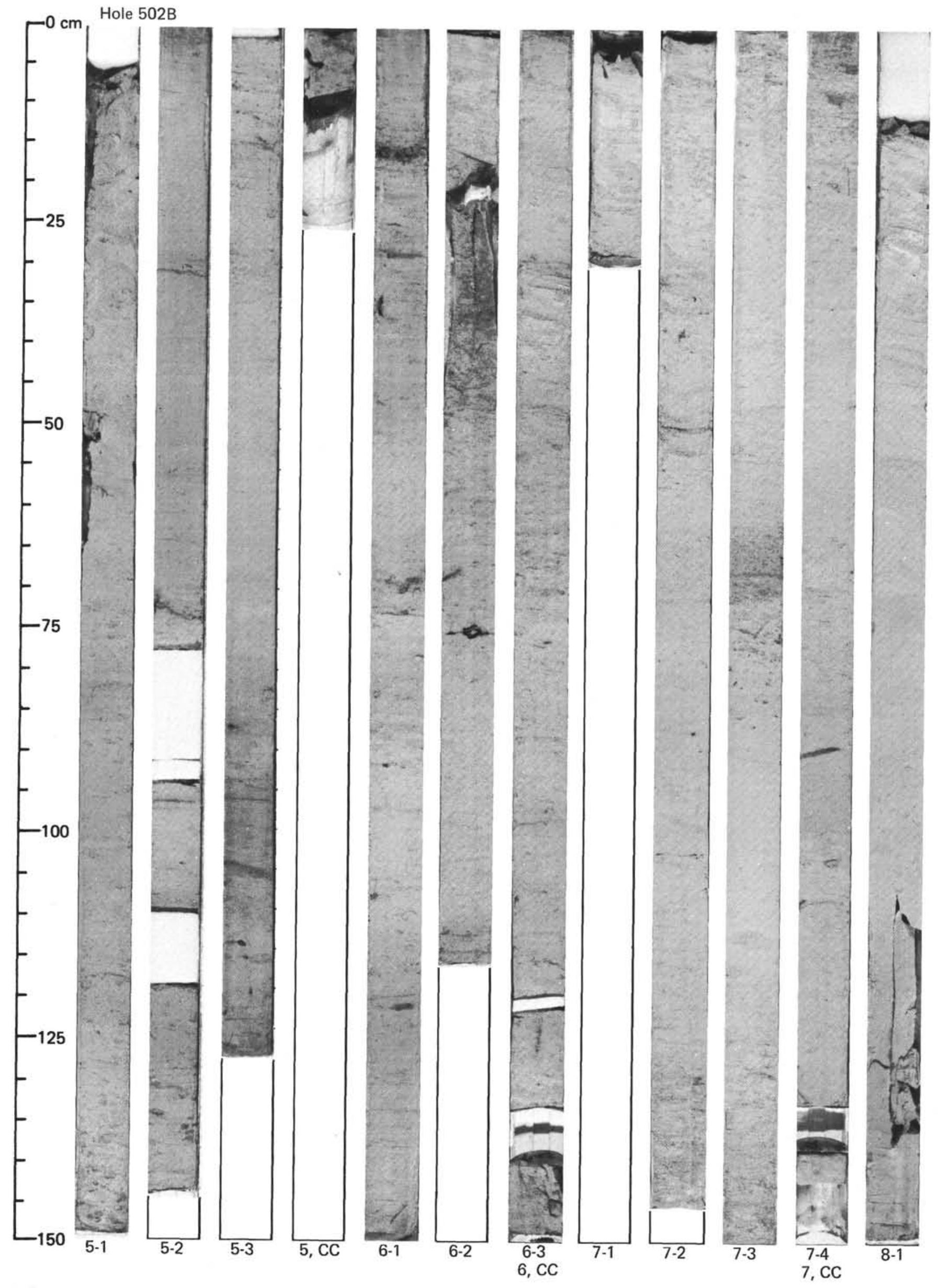




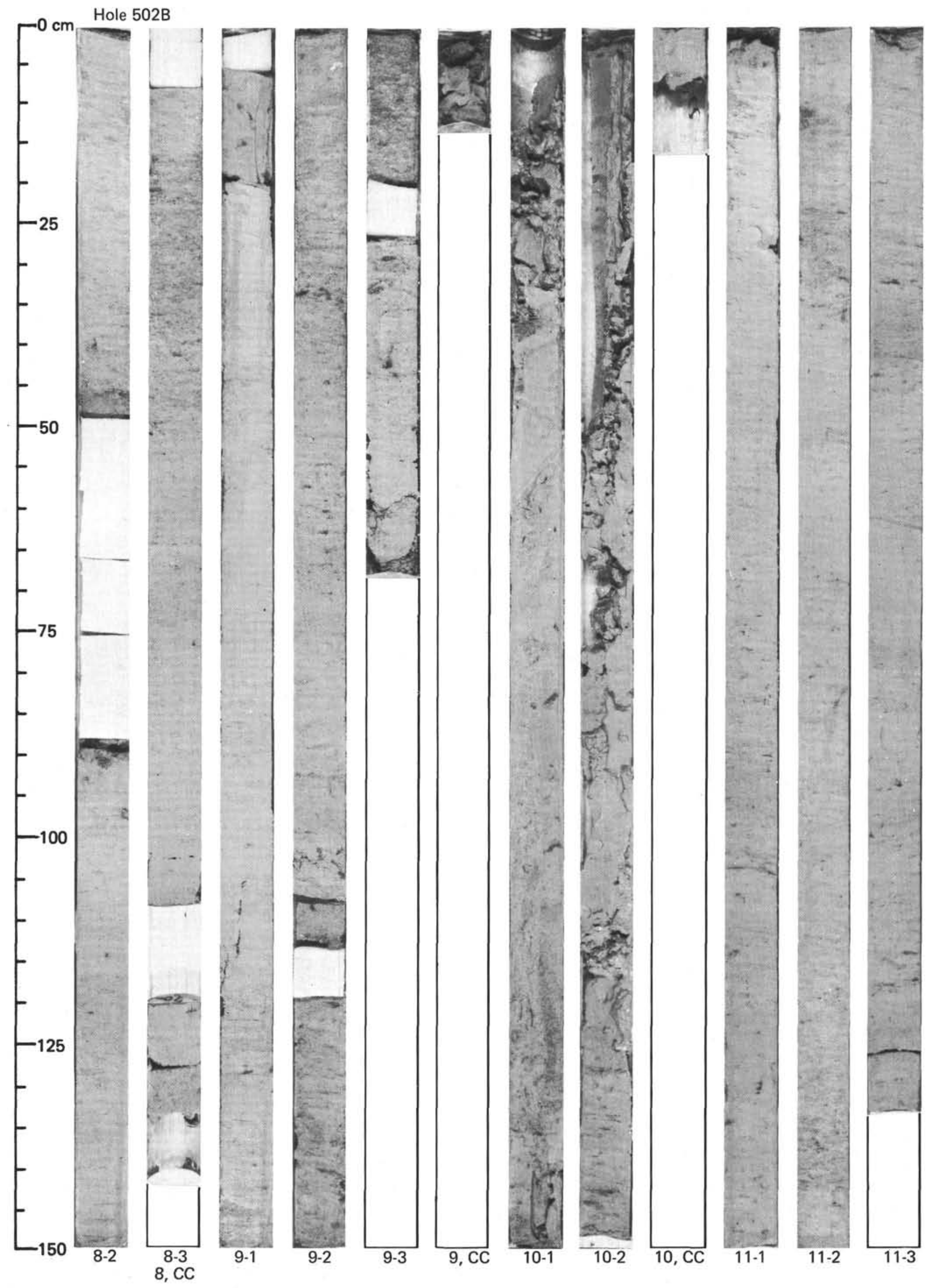




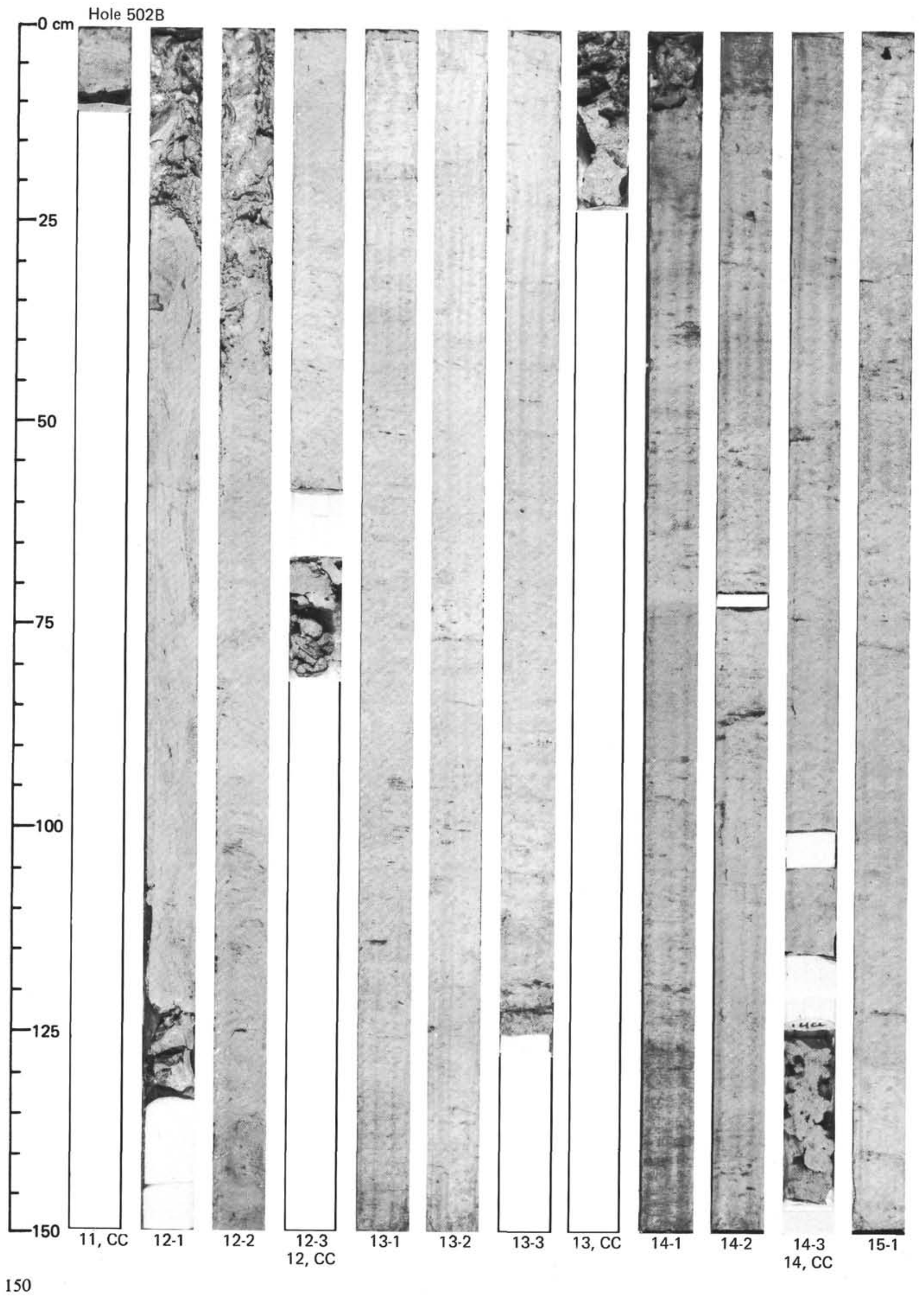




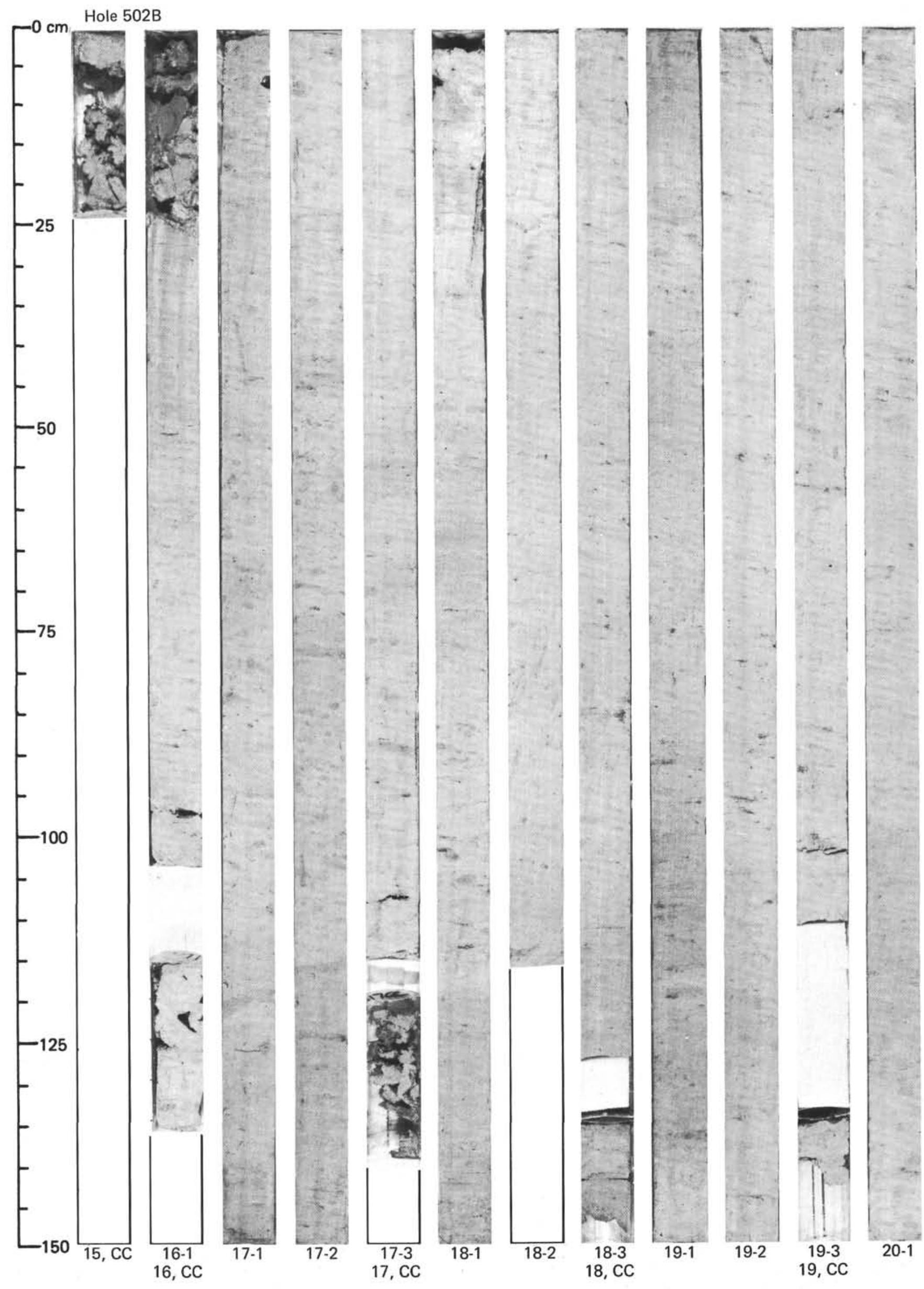




\section{SITE 502}

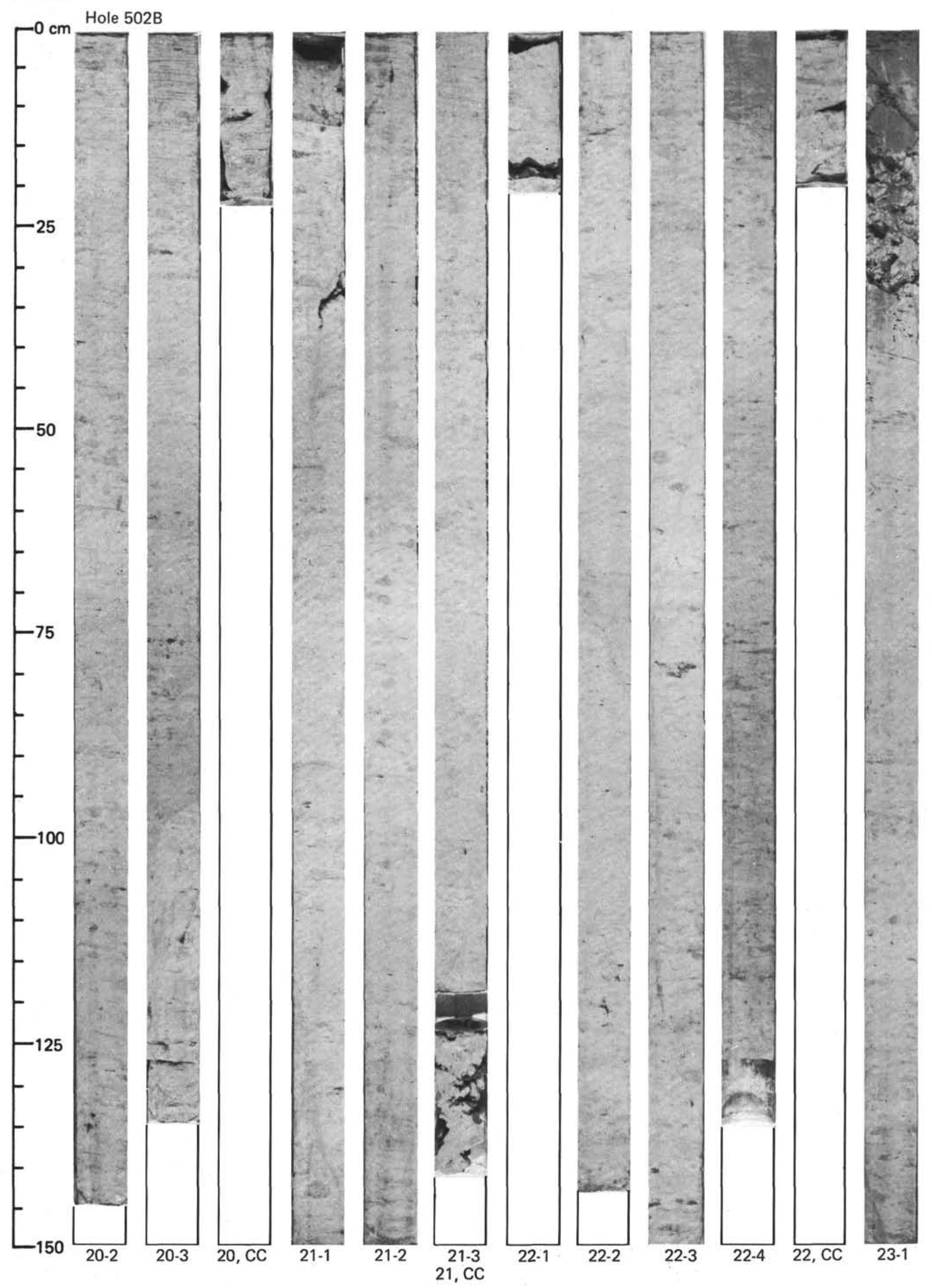




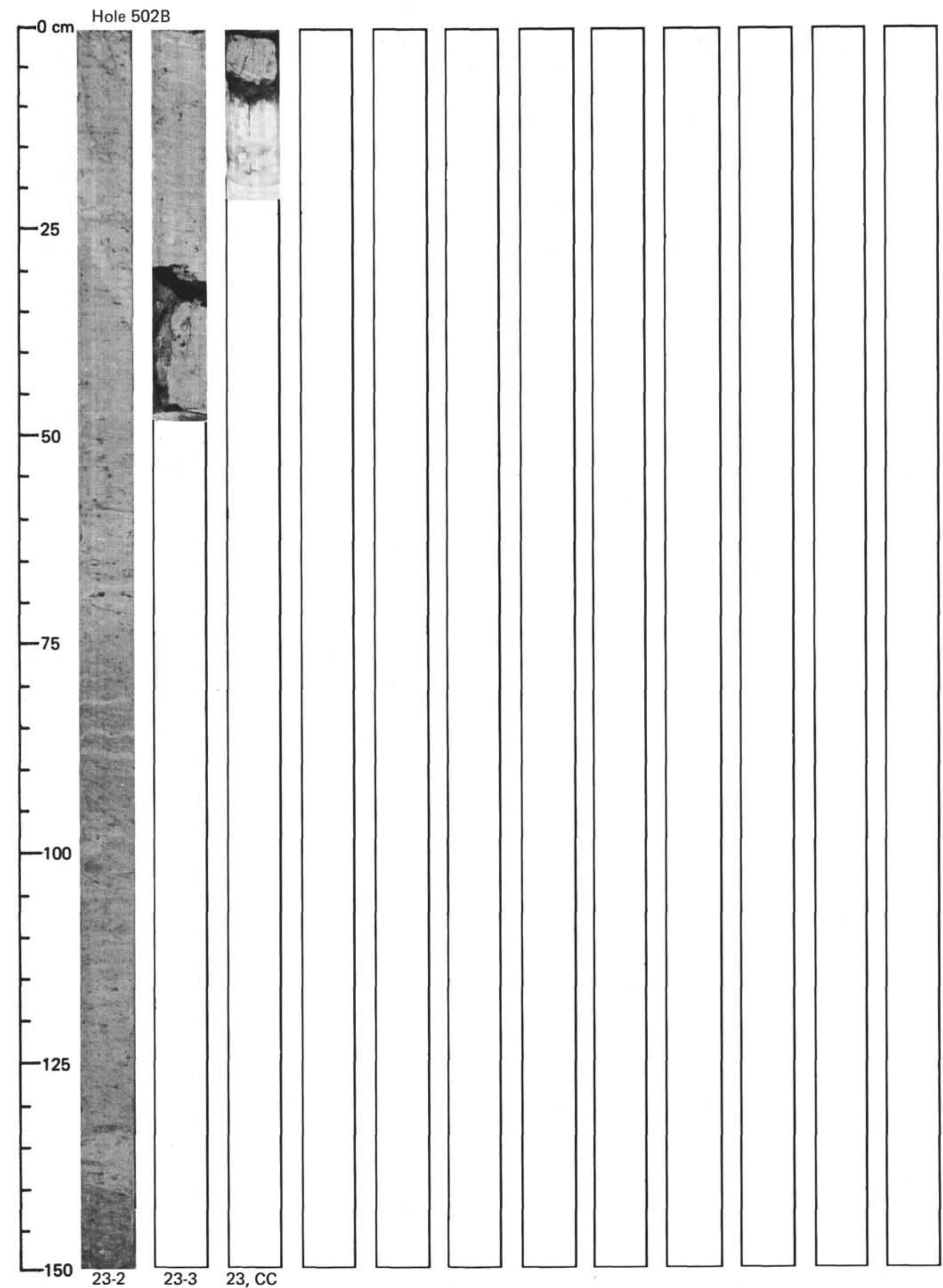




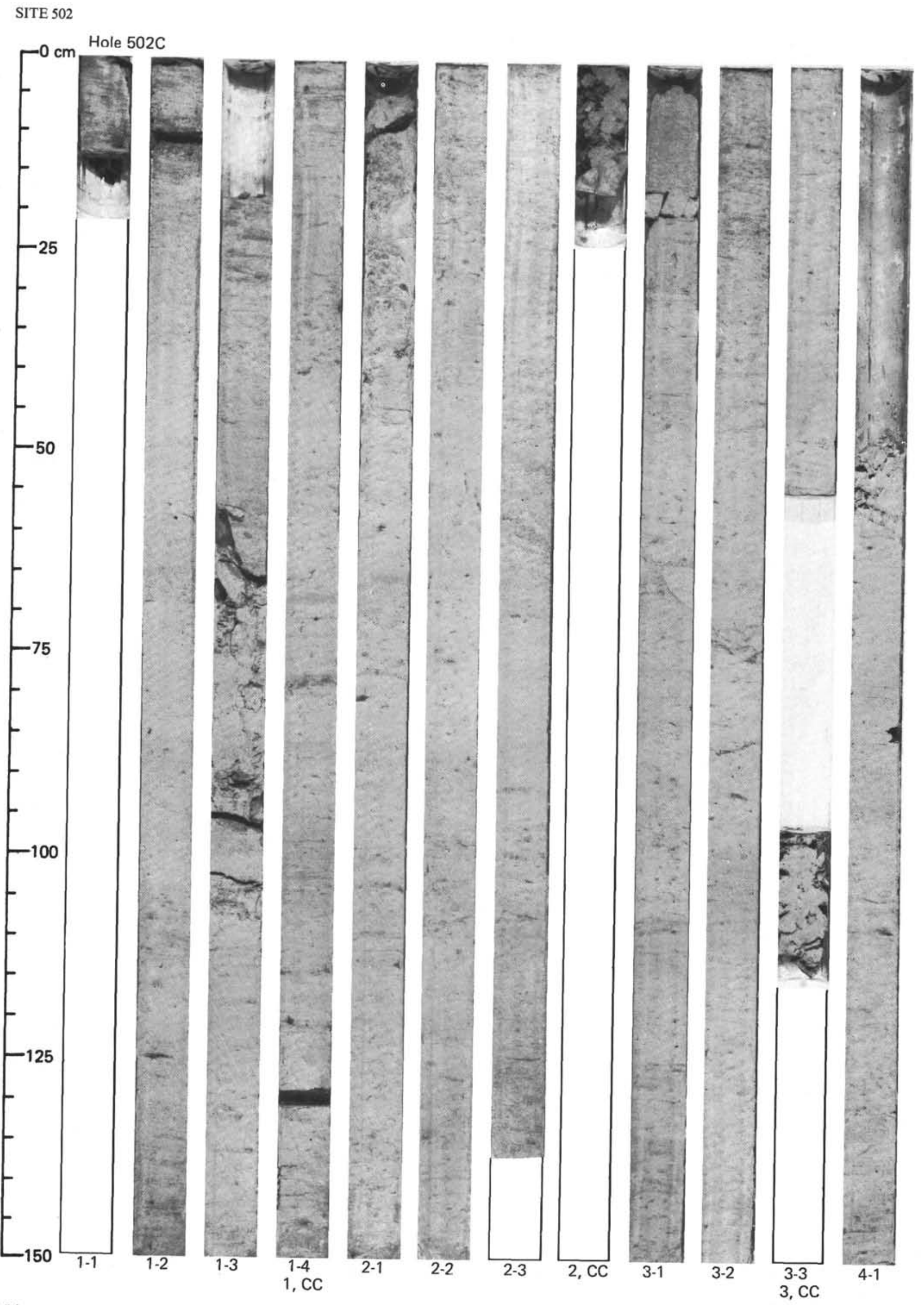




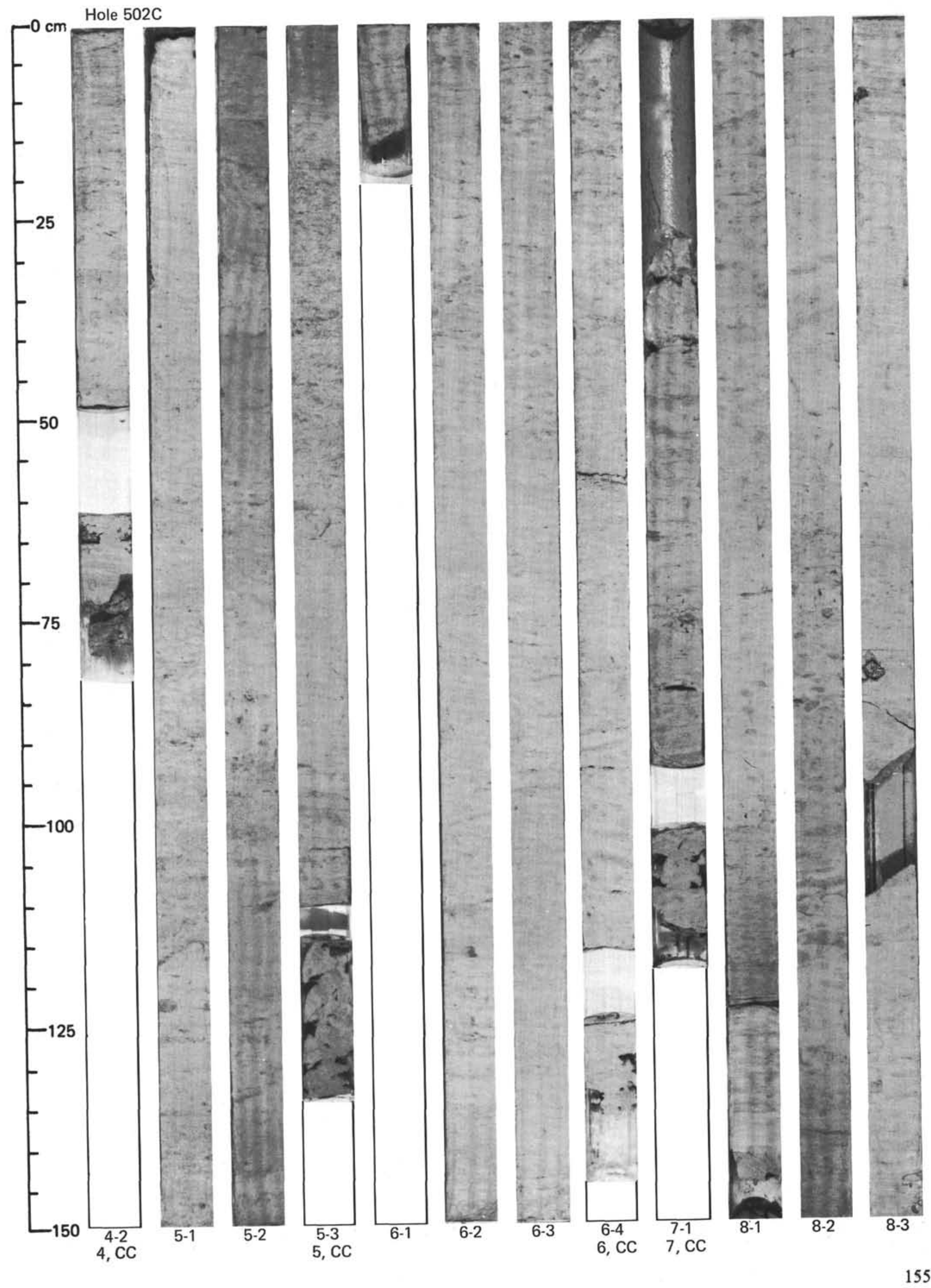




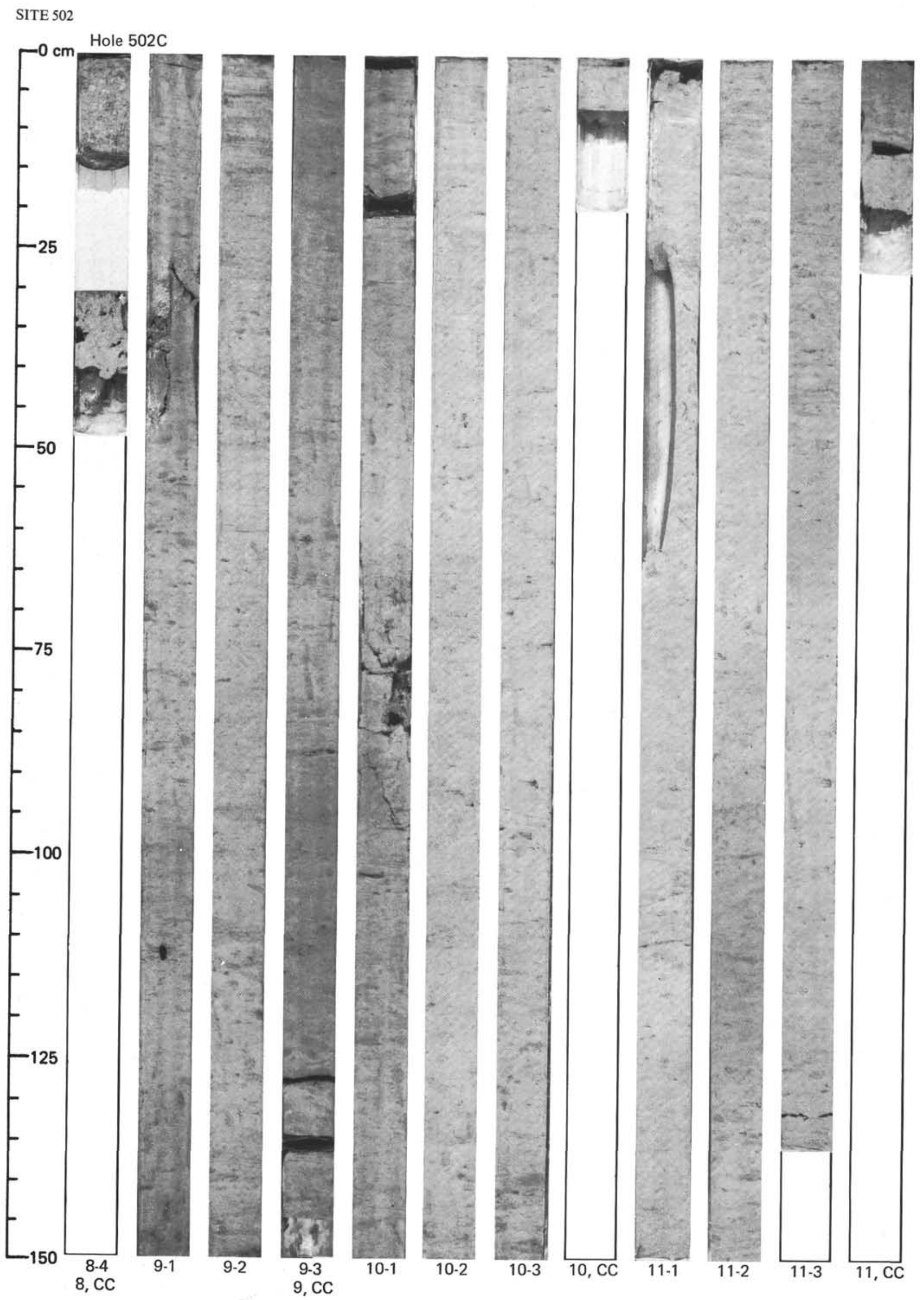



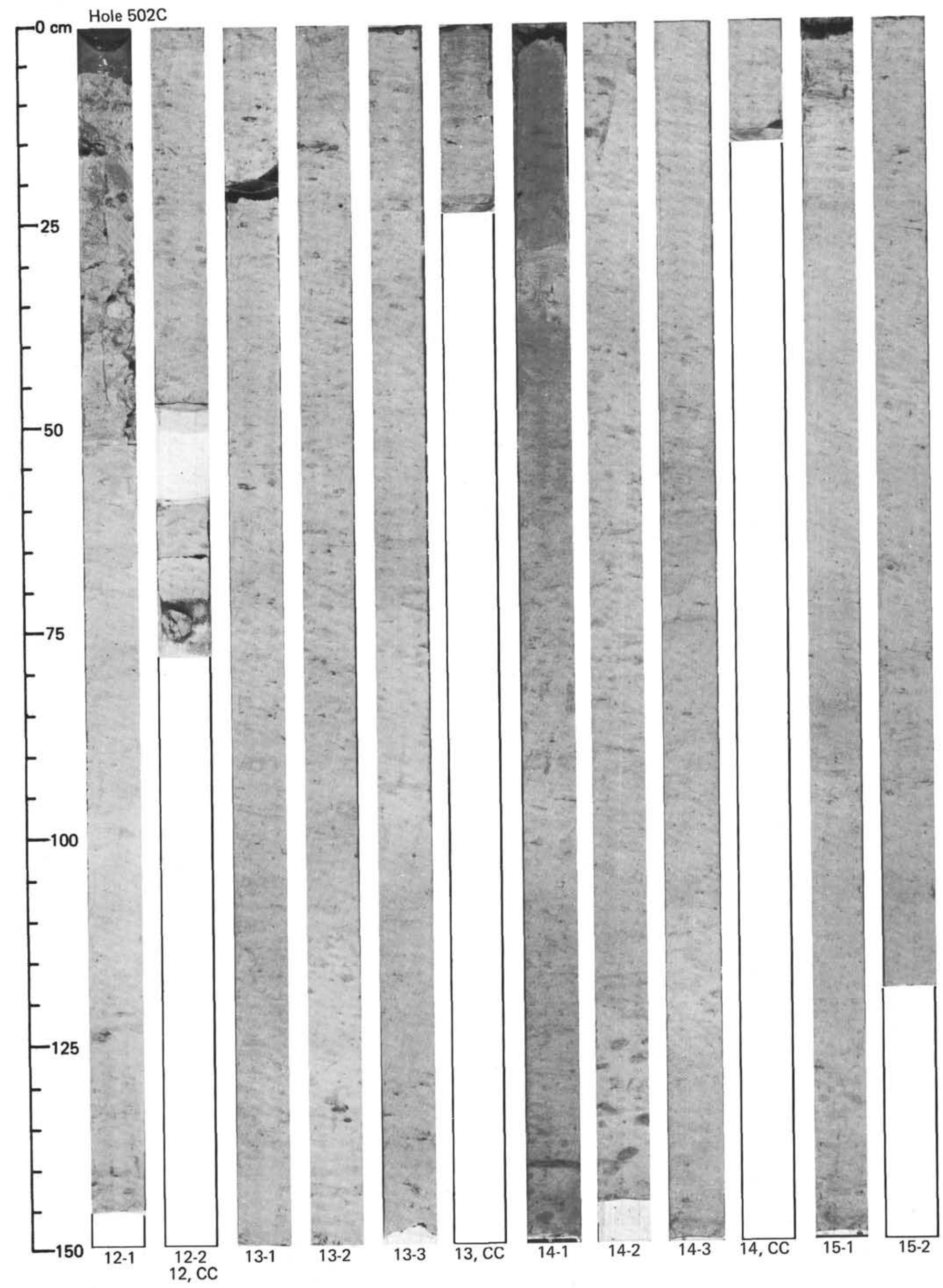


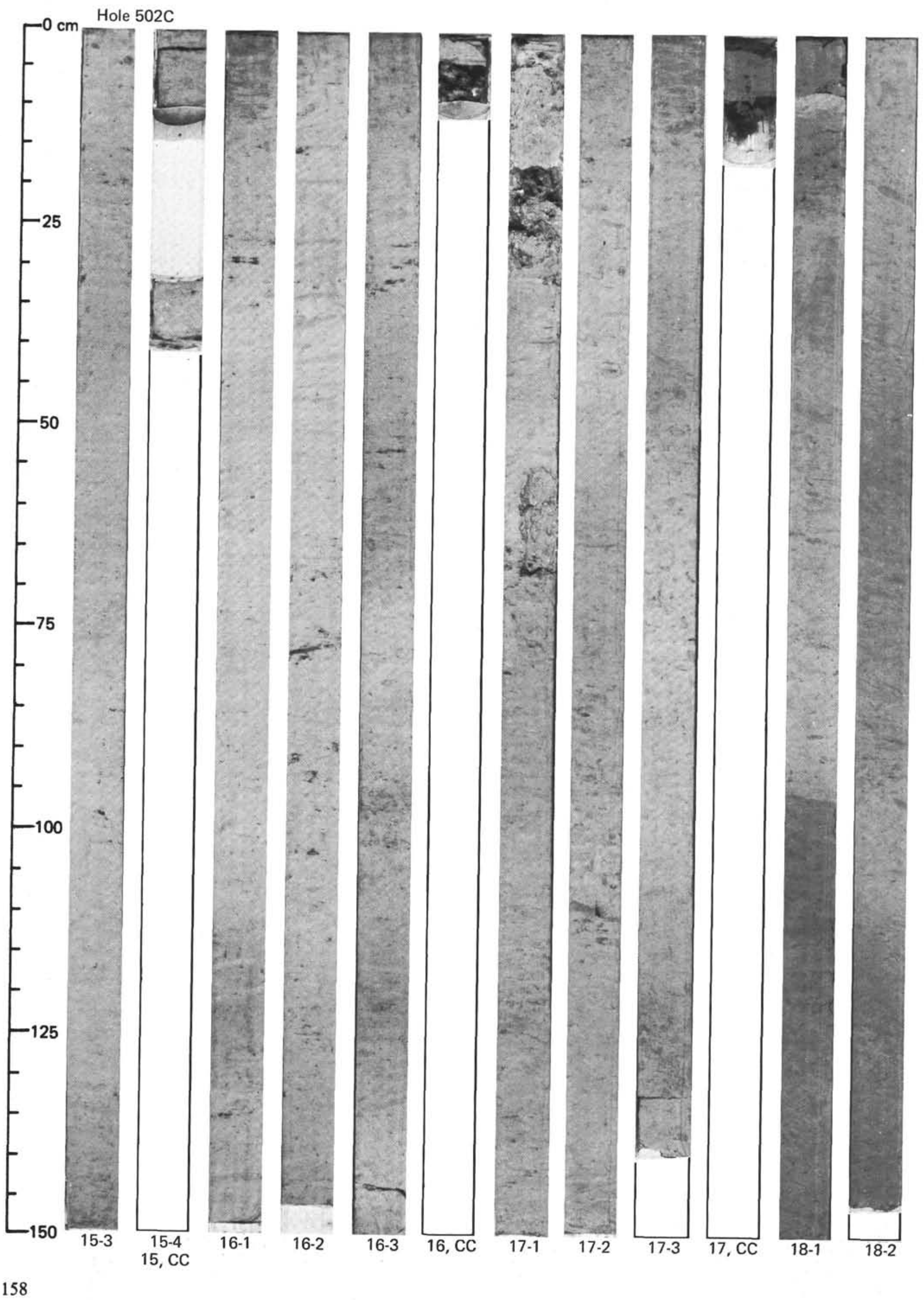




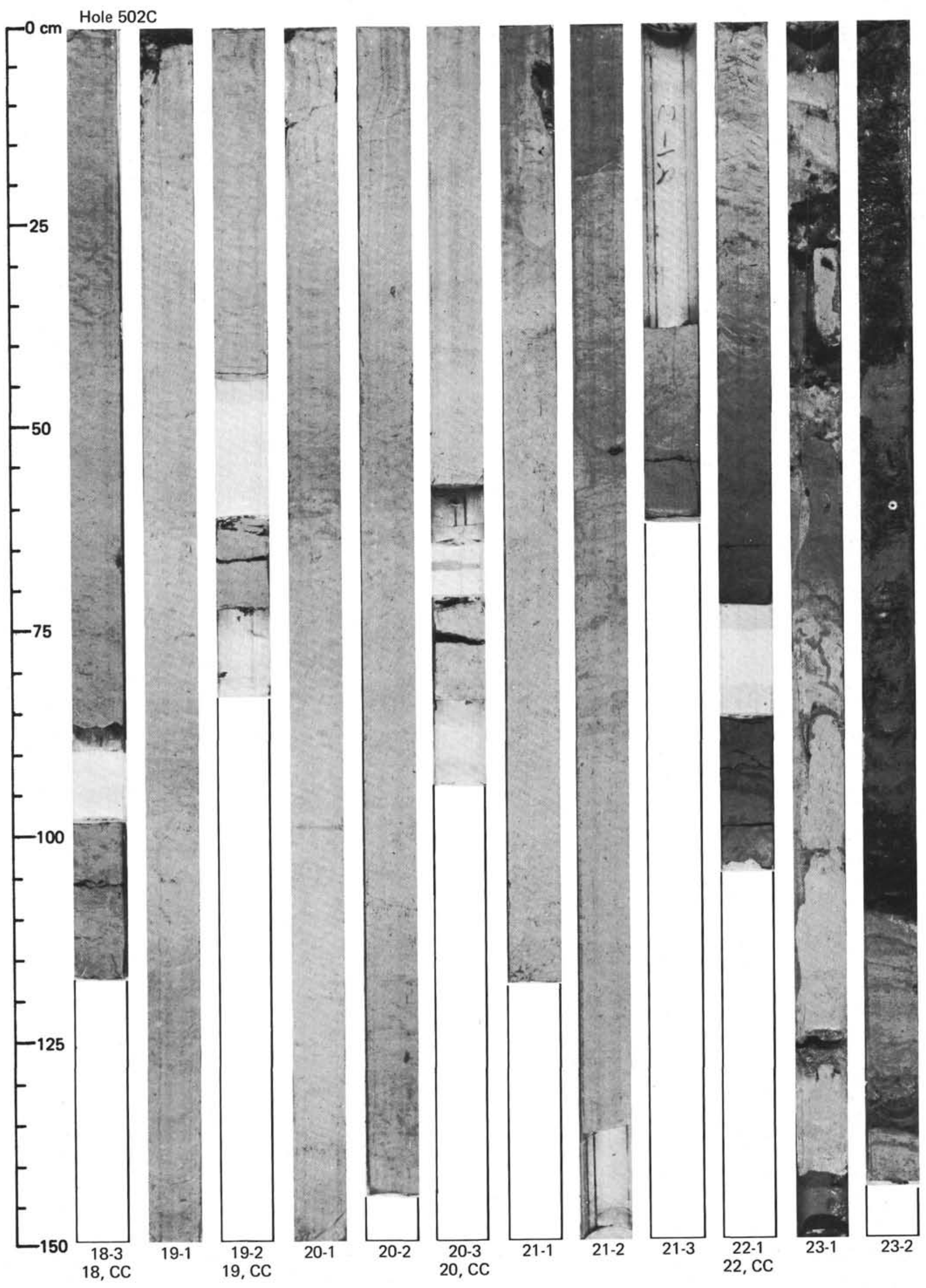




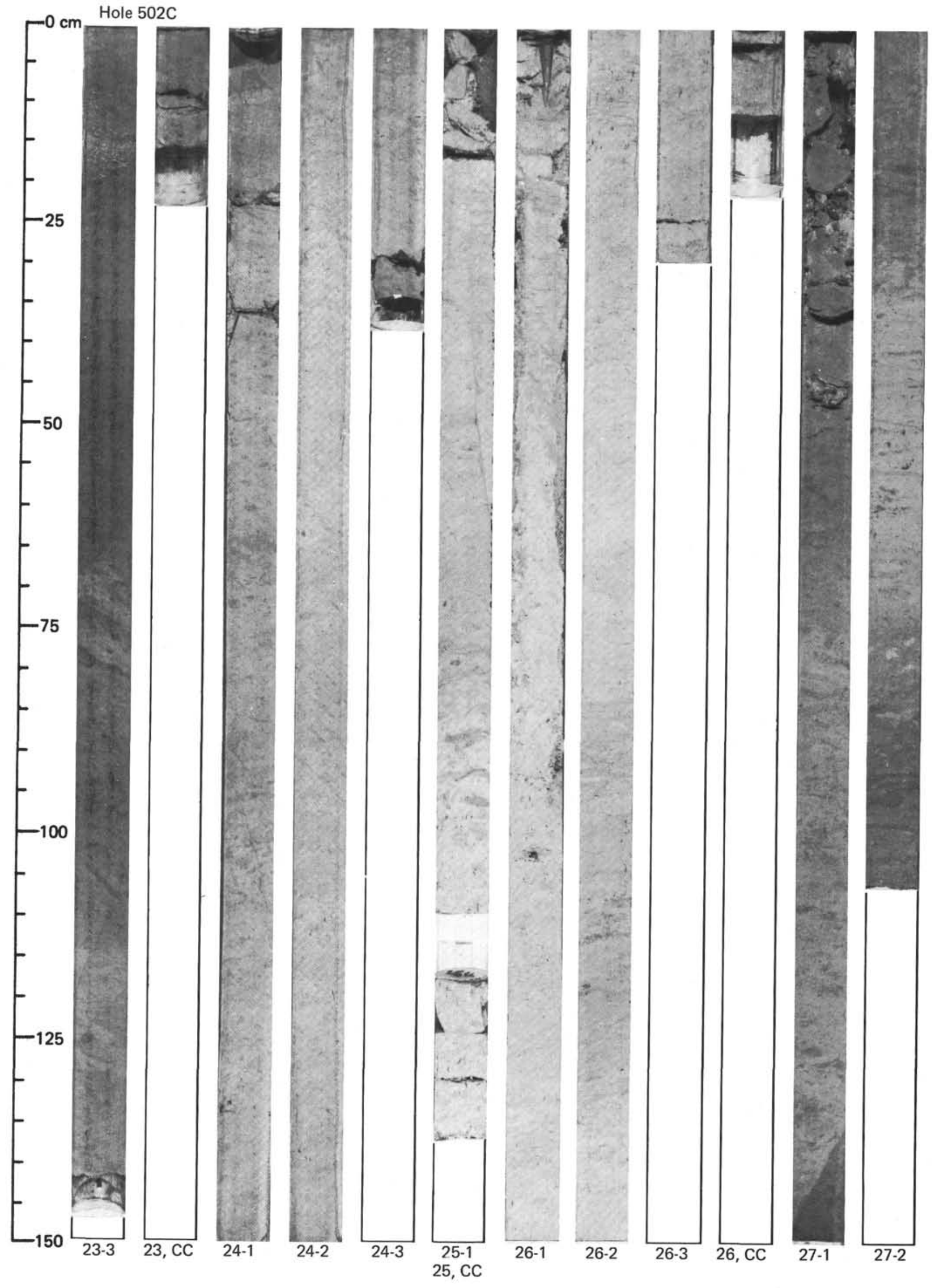




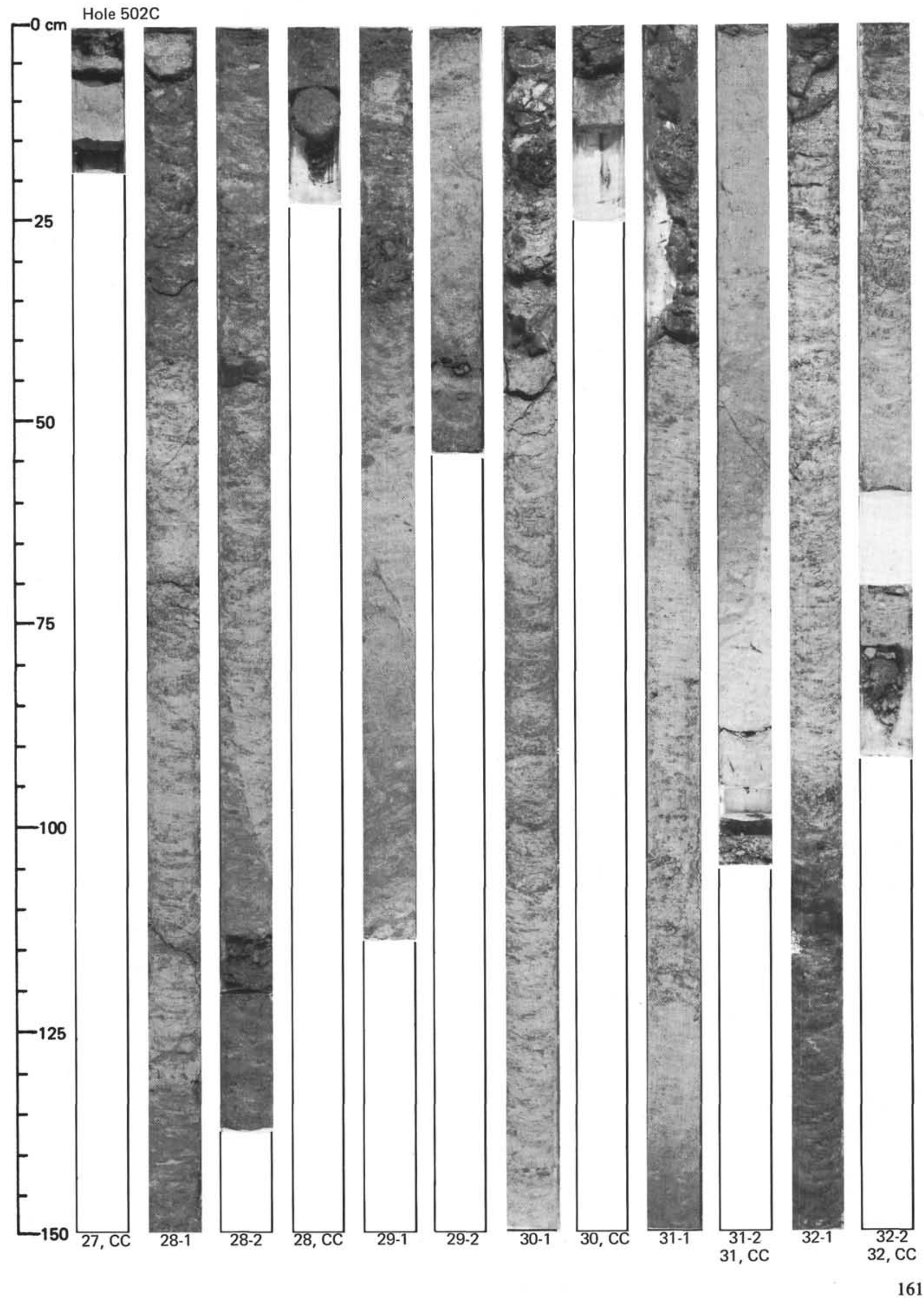




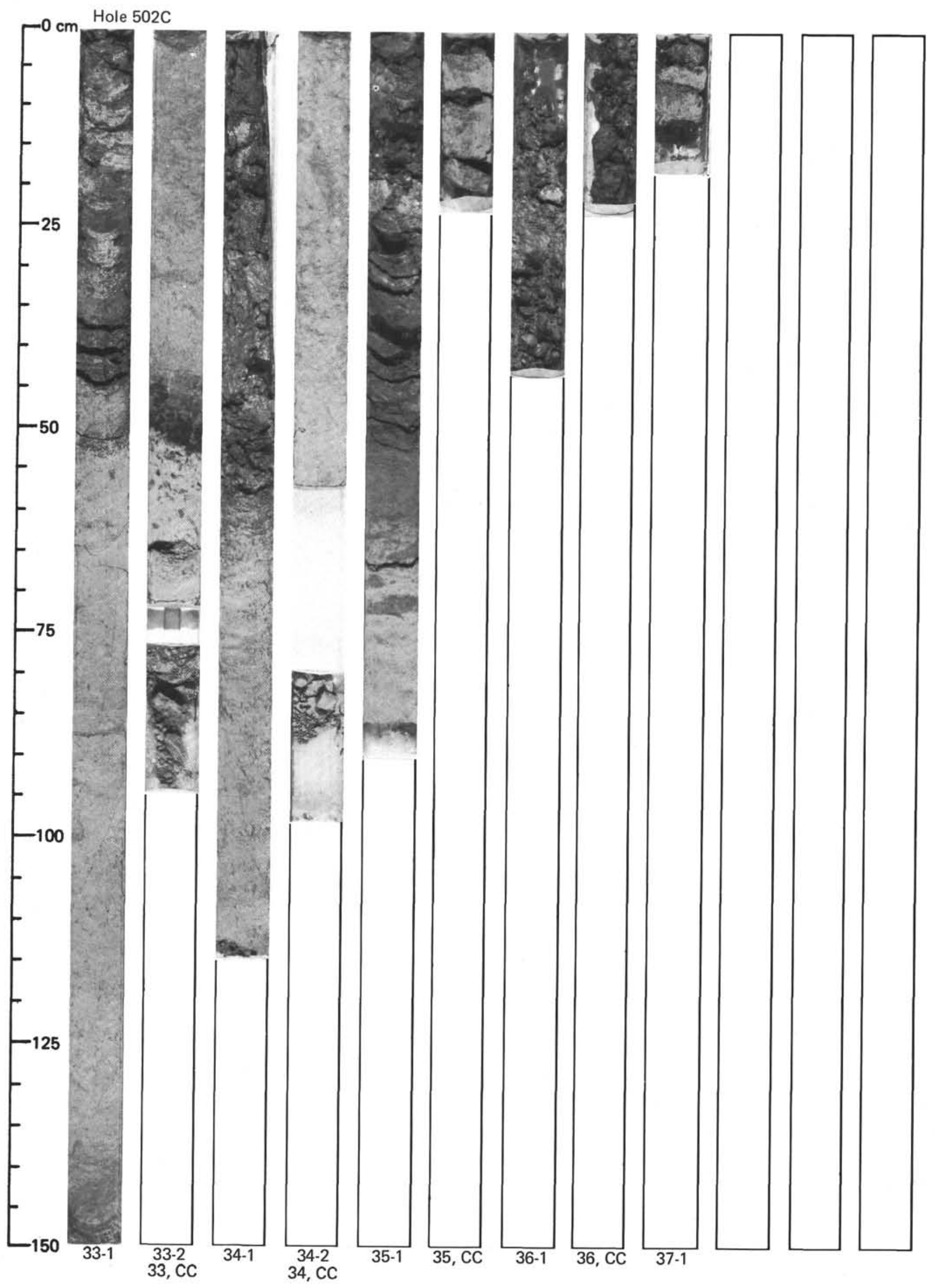

